UNIVERSIDADE DE SÃO PAULO

FACULDADE DE ARQUITETURA E URBANISMO

\title{
NOVOS OLHARES
}

UMA LEITURA DA CIDADE POR SUAS CRIANÇAS

PAULA MARTINS VICENTE

SÃO PAULO, 2018

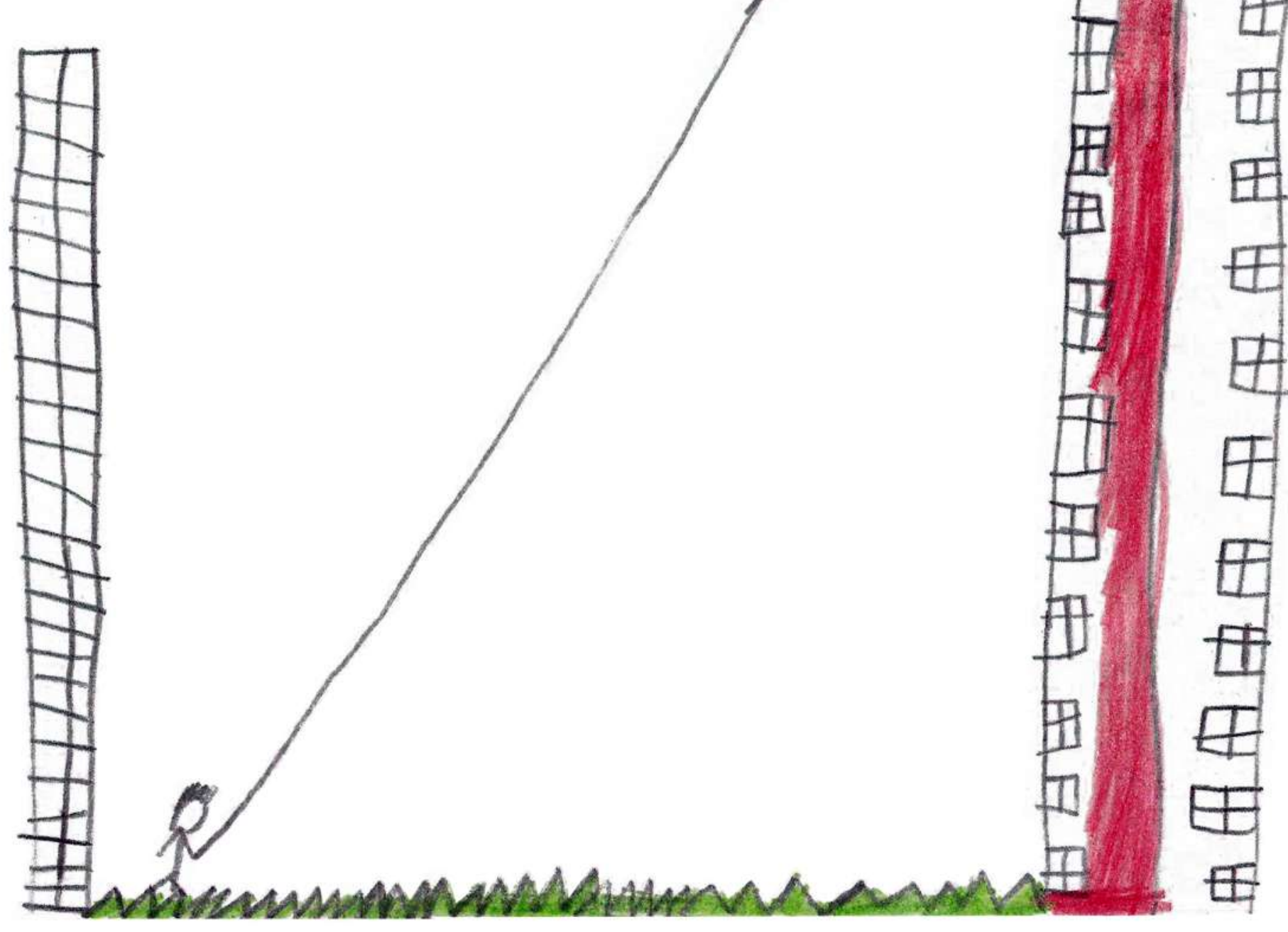




\section{NOVOS OLHARES \\ UMA LEITURA DA CIDADE POR SUAS CRIANÇAS}

PAULA MARTINS VICENTE

Dissertação apresentada à Faculdade de Arquitetura e Urbanismo da Universidade de São Paulo para obtenção do título de Mestre em Arquitetura e Urbanismo.

Área de Concentração: Paisagem e Ambiente

Orientadora: Profa. Dra. Catharina Pinheiro Cordeiro dos Santos Lima

São Paulo, 2018. 
Autorizo a reprodução e divulgação total ou parcial deste trabalho, por qualquer meio convencional ou eletrônico, para fins de estudo e pesquisa, desde que citada a fonte.

e-mail: paulamv.arq@gmail.com

Catalogação na Publicação

Serviço Técnico de Biblioteca

Faculdade de Arquitetura e Urbanismo da Universidade de São Paulo

Vicente, Paula Martins

Novos Olhares: uma leitura da cidade por suas

crianças / Paula Martins Vicente; orientador

Catharina Pinheiro Cordeiro dos Santos Limas. - São Paulo,

2018.

$268 \mathrm{p}$

Dissertação (Mestrado) - Faculdade de Arquitetura

e Urbanismo da Universidade de São Paulo. Área de

concentração: Paisagem e Ambiente

1. Cidade. 2. Crianças. 3. Espaço Público. 4.

Participação Infantil. I. Lima, Catharina Pinheiro Cordeiro

dos Santos. orient. II. Título. 


\section{FOLHA DE APROVAÇÃO}

Nome: VICENTE, Paula Martins.

Título: Novos Olhares: uma leitura da cidade por suas crianças.

Dissertação apresentada à Faculdade de Arquitetura e Urbanismo da Universidade de São Paulo para obtenção do título de Mestre em Arquitetura e Urbanismo.

Área de Concentração: Paisagem e Ambiente.

Aprovado em:

\section{BANCA EXAMINADORA}

Prof. Dr. Instituição:

Julgamento:

Assinatura:

Prof. Dr. Instituição:

Julgamento:

Assinatura:

Prof. Dr. Instituição:

Julgamento:

Assinatura: 

Às crianças participantes desta pesquisa. 



\section{AGRADECIMENTOS}

Primeiramente, a todas as crianças participantes dessa pesquisa, que foram fundamentais para a elaboração desse trabalho, trazendo-me novos pontos de vista e inquietações que fizeram-me pensar sobre o papel da arquitetura junto a elas.

À professora Vera Valgas que confiou e, gentilmente, abriu as portas das suas aulas para que eu pudesse realizar as oficinas e atividades com seus alunos.

À professora Catharina Lima, que sempre confiou em mim, dando-me toda a orientação, o incentivo e o apoio necessários para o desenvolvimento e a conclusão desse trabalho. Obrigada por toda a inspiração e parceria desde os anos de graduação, na certeza de que ainda teremos muitas outras experiências e aprendizados a compartilharmos juntas.

Aos meus pais - Sonia e Roberto -, à minha irmã Eloisa e ao meu cunhado Emmanuel, por todo o apoio e compreensão, que, muitas vezes, sem saber ao certo o que estava acontecendo durante esse período, entenderam as ausências em aniversários, datas importantes e no dia-a-dia, em que eu acabei "trocando-os" por livros, computador, eventos e outras atividades. Muito obrigada!

Em especial, à minha irmã Beatriz, por todos os motivos citados à minha família e pela ajuda essencial na etapa final desse trabalho, com suas leituras, conversas, desabafos, puxões de orelha, momentos de descontração e risadas.

À Marcia Gobbi e Raul Pereira, que desde a banca de qualificação e conversas informais trouxeram-me contribuições e referências paranovas reflexões, possibilidades de continuidade e encaminhamento da pesquisa.

Às professoras Maria Letícia Nascimento, Elcie Masini e Rosângela Francischini, que através de conversas, referências e trocas de experiências auxiliaram nos rumos tomados por esse trabalho. 
Aos professores e colegas de turma das disciplinas de pós-graduação cursadas na Faculdade de Arquitetura e Urbanismo e na Faculdade de Educação, que auxiliaram meu crescimento intelectual e humano, através das trocas nas diversas áreas de conhecimento.

Aos amigos Leandro Fontana, Claudia Kawakami, Margarida Barbosa, Paula Custódio, Paula Hori e Tatiana Francischini por todo o auxílio, opiniões, conversas, participação em oficina com as crianças, leitura de textos, participação em colóquio e apoio recebido.

A todos os demais amigos pelo incentivo, palavras e vibrações positivas que recebi nesse período e que, estando próximos ou distantes, foram importantíssimos para a continuidade e o desenvolvimento desse trabalho.

Aos amigos e profissionais que estiveram comigo durante esse período permitindo que eu tivesse o equilíbrio físico, espiritual e psicológico necessários para a realização da pesquisa.

À equipe do LabLaje, às meninas do Co-Criança e às colegas do ROC, que através de oficinas, conversas, incentivos e incertezas compartilhadas permitiram a abertura para novos desafios.

A todos aqueles - crianças e adultos- que, de alguma forma, cruzaram essa trajetória investigativa e que, direta ou indiretamente, trouxeram momentos de aprendizados importantes para as reflexões aqui elaboradas.

À Coordenação de Aperfeiçoamento de Pessoal de Nível Superior (CAPES) pelo apoio concedido, através de bolsa de pesquisa, ao desenvolvimento desse trabalho. 
Tenho o privilégio de não saber quase tudo.

E isso explica

o resto.

Manoel de Barros'

1 BARROS, Manuel. Menino do mato. 1ª ed. Rio de Janeiro: Objetiva/ Alfaguara, 2015. 

A cidade constitui-se hoje como um local de conflitos e disputas, sejam eles em níveis sociais, econômicos, políticos e culturais, como também de interesses distintos de usos e apropriações etárias, restringindo, cada vez mais, a participação infantil nos espaços públicos.

A partir dessa constatação, a presente pesquisa desenvolve-se colocando as crianças como sujeitos e atores sociais para refletir, junto aos diferentes profissionais, sobre a construção dos espaços livres urbanos. Nesse sentido, as leituras infantis são trabalhadas como ponto de partida para a identificação das temáticas existentes nesses cenários.

Por meio de uma série de oficinas realizadas com meninos e meninas moradores do distrito do Jaraguá, na região Noroeste do Município de São Paulo, trabalhou-se com as interpretações e os projetos urbanos elaborados por eles, abordando assuntos que envolvem, sobretudo, questões observadas em seus espaços cotidianos.

Essa experiência institui-se como ponto central da pesquisa, que, através de interlocuções constantes com os diferentes campos teóricos abordados, estabelece uma oportunidade para analisar, não apenas os olhares infantis no e do espaço urbano, mas também a produção da cidade que estamos promovendo e vivenciando, colocando-nos para refletir sobre quais interesses estamos atendendo e privilegiando. 


\section{ABSTRACT}

Nowadays the city is a place of conflicts and disputes, be they at social, economic, political and cultural levels, as well as different interests of age appropriations and uses wich increasingly restricts children's participation in public spaces.

Based on this assumption, the present research is developed considering children as social actors to reflect, together with different professionals, on the construction of urban spaces. In this sense, children's perseptions are worked as a starting point for the identification of themes in these scenarios.

Through a series of workshops developed with boys and girls to live in the district of Jaraguá, in the Northwest Region of the Municipality of São Paulo, we worked on the interpretations and urban projects elaborated by them, addressing issues that mainly involve subjects observed in their routine spaces.

This experience was as a central point of the research, which, through constant dialogues with different theoretical approaches, establishes an opportunity to reflect not only on children's views in and of urban space, but also on the production of the city that we are promoting and experiencing, putting ourselves to think about what interests we are attending and privileging. 


\section{LISTA DE FIGURAS}

CAPA - Desenho elaborado por Felipe. Resposta ao questionamento sobre 'o que você fez no fim de semana?'

FIGURA 01 - Fotografia feita pelo grupo de Deyvid, Lívia e Pyetra durante visita ao entorno da escola........

FIGURA 02 - Desenho elaborado por Guilherme. Resposta dada ao questionamento sobre 'o que você gostaria que tivesse em seu bairro'

FIGURA 03 - Ilustração de Tonucci 47

FIGURA04- Ilustração deTonucci. .53

FIGURA05-Ilustração deTonucci.

FIGURA 06 - Fotografia feita pelo grupo de Débora, Guilherme e Thainá durante visita ao entorno da escola.

FIGURA 07 - Localização da Escola em seu entorno imediato .74

FIGURA 08 - Escalas de usos e apropriações da cidade......

FIGURA 09 - Foto aérea dos bairros City Jaraguá, Jardim Rincão, Parque Panamericano e Parque Nações Unidas......

FIGURA 10 - Mapa Turístico do Rio de Janeiro. .81

FIGURA 11 - Ilustrações da cidade de Paris.

FIGURA 12 - Lista de elementos existentes na cidade de São Paulo.

FIGURA 13 - Localização de equipamentos públicos sobre Mapa Oficial do Município de São Paulo.

FIGURA 14 - Percurso realizado pelas crianças durante a Oficina 03.

FIGURA 15 - Crianças durante a visita ao entorno da escola.

FIGURA 17 -Crianças em processo investigativo do bairro sobre foto aérea

FIGURA 18 - Localização das casas das crianças e dos equipamentos do bairro.

FIGURAS 19 e 20 - Crianças durante o processo de elaboração dos desenhos em resposta às temáticas solicitadas. 
FIGURA 21- Desenho retratando a brincadeira preferida de um dos meninos participantes das oficinas (esconde-esconde)

FIGURA 22 - Desenho retratando o que uma das meninas gostaria que tivesse no bairro onde mora

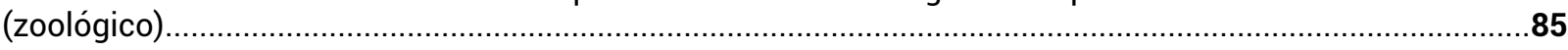

FIGURA 23 - Crianças durante conversa sobre as possibilidades de usos nos espaços públicos...................86

FIGURAS 24, 25, 26, 27 e 28 - Indicação de possibilidades de usos nos espaços urbanos..........................86

FIGURA 29 - Desenho elaborado representando o imaginário do Jardim Botânico, antes da visita................87

FIGURA 30 - Crianças durante a visita ao Jardim Botânico..........................................................................

FIGURA 31 e 32 - Desenhos retratando o que foi observado no Jardim Botânico............................................87

FIGURA 33, 34, 35 e 36 - Crianças separadas em grupos durante o processo de elaboração das maquetes para representar aquilo que gostariam de construir na cidade ................................................................8

FIGURA 37 - Maquete elaborada com o projeto de um parque aquático.........................................................89

FIGURA 38 - Maquete elaborada com o projeto de um shopping center......................................................89

FIGURA 39 - Maquete elaborada com o projeto de um condomínio habitacional com equipamentos...........89

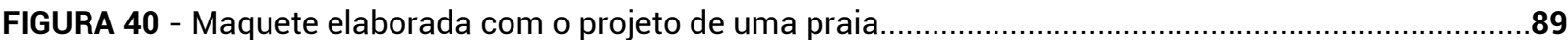

FIGURA 41 - Crianças soltando as bexigas com pedidos para serem conduzidas, simbolicamente, pelo vento

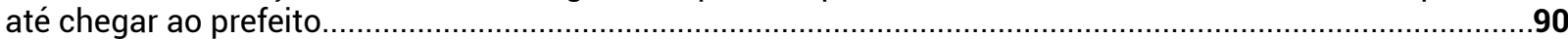

FIGURA 42 e 43 - Livrinhos entregues às crianças com suas produções...................................................90

FIGURA 44 - Desenho elaborado por Deyvid. Percurso realizado de carro de casa até a escola...................99

FIGURA 45 - Fotografia feita pelo grupo de Deyvid, Lívia e Pyetra durante visita ao entorno da escola........103

FIGURA 46 - Localização da área de estudo sobre foto aérea..................................................................108

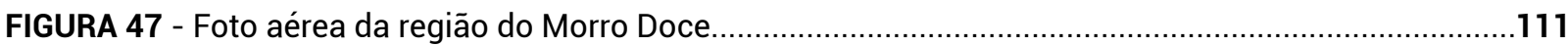

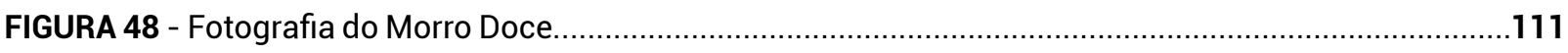

FIGURA 49 - Foto aérea da região de Perus..........................................................................................11

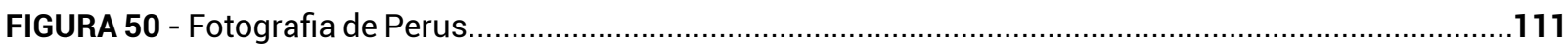

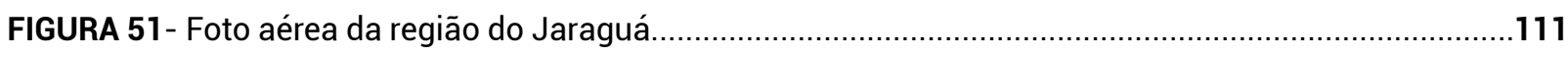

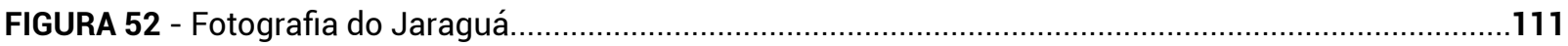

FIGURA 53 - Desenho elaborado por Pyetra. Percurso realizado a pé de casa até a escola.......................113

FIGURA 54 - Desenho elaborado por Thayná. Percurso realizado a pé de casa até a escola.......................115 
FIGURA 55 - Desenho elaborado por Kauê. Percurso realizado de transporte escolar (perua) de casa até a escola.

FIGURA 56 - Desenho elaborado por Maria Vitória. Percurso realizado de transporte escolar (perua) de casa até a escola.

FIGURA 57 - Desenho elaborado por Yasmin. Parque de diversões, em resposta ao questionamento sobre 'o que você gostaria que tivesse no seu bairro?'.

FIGURA 58 - Desenho elaborado por Débora. Festa de aniversário, em resposta ao questionamento sobre 'o que você gostaria que tivesse no seu bairro?'.

FIGURA 59 - Identificação e localização das casas das crianças sobre foto aérea

FIGURA 60 - Fotografia feita pelo grupo de Gustavo e Izabela durante visita ao entorno da escola.

FIGURA 61 - Fotografia feita pelo grupo de Danilo e Gabriel durante visita ao entorno da escola.

FIGURA 62 - Fotografia feita pelo grupo de Deyvid, Lívia e Pyetra durante visita ao entorno da escola...

FIGURA 63 - Fotografia feita pelo grupo de Gustavo e Izabela durante visita ao entorno da escola....129

FIGURA 64 - Distribuição de equipamentos públicos de assistência social, cultura, educação, esporte e saúde.

FIGURA 65 - Distribuição e acessos a parques, equipamentos de esporte e cultura

FIGURA 66 - Desenho elaborado por Lívia. Shopping Cantareira Norte, em resposta ao questionamento sobre 'o que você fez no fim de semana?'.

FIGURA 67 - Desenho elaborado por Débora. Shopping Cantareira Norte, em resposta ao questionamento sobre 'qual brincadeira você mais gosta?'

FIGURA 68 - Desenho elaborado por Bárbara. Livraria do Shopping Cantareira Norte, em resposta ao questionamento sobre 'qual brincadeira você mais gosta?'.....

FIGURA 69 - Fotografia feita pelo grupo de Danilo e Gabriel durante visita ao entorno da escola.........

FIGURA 70 - Fotografia feita pelo grupo de Gustavo e Izabela durante visita ao entorno da escola..

FIGURA 71 - Desenho elaborado por Bárbara. Casa da tia, em resposta ao questionamento sobre 'o que você fez no fim de semana?'.

FIGURA 72 - Desenho elaborado por Nicolly. Parquinho no prédio onde mora, em resposta ao questionamento sobre 'o que você fez no fim de semana?'..... 
FIGURA 73 - Desenho elaborado por Gabriel. Brinquedos no parquinho do prédio onde mora, em resposta ao questionamento sobre 'qual brincadeira você mais gosta? ...........................................171

FIGURA 74 - Desenho elaborado por Pyetra. Registro após visita ao entorno da escola.................177

FIGURA 75 - Desenho elaborado por Thainá. Registro durante visita ao Jardim Botânico identificando elementos observados no local.

FIGURA 76 - Fotografia feita pelo grupo de Danilo e Gabriel durante visita ao entorno da escola.

FIGURA 77 - Fotografia feita pelo grupo de Danilo e Gabriel durante visita ao entorno da escola.

FIGURA 78 - Fotografia feita pelo grupo de Deyvid, Lívia e Pyetra durante visita ao entorno da escola.

FIGURA 79 - Fotografia feita pelo grupo de Débora, Guilherme e Thainá durante visita ao entorno da escola.

FIGURA 80 - Fotografia feita pelo grupo de Maria Eduarda, Nicolly e Yasmim durante visita ao entorno da escola...

FIGURA 81 - Fotografia feita pelo grupo de Débora, Guilherme e Thainá durante visita ao entorno da escola.

FIGURA 82 - Desenho elaborado por Davi. Consertar os buracos das ruas em resposta ao questionamento sobre 'o que você gostaria que tivesse no seu bairro?'..........................................187

FIGURA 83 - Ilustração de Tonucci 201

FIGURA 84 - Vista do centro de São Paulo a partir do Edifício Copan 203

FIGURA 85 - Praça Euclides da Cunha, em São Luiz do Paraitinga.

FIGURA 86 - Desenho elaborado por Beatriz. Sorveteria e pula-pula, em resposta ao questionamento sobre 'o que você gostaria que tivesse no seu bairro?'

FIGURA 87 - Desenho elaborado por Maria Eduarda. Parquinho com brinquedos e mesa, em resposta ao questionamento sobre 'o que você gostaria que tivesse no seu bairro?'.....

FIGURA 88 - Desenho elaborado por Maria Vitória. Parque com árvores, em resposta ao questionamento sobre 'o que você gostaria que tivesse no seu bairro?'

FIGURA 89 - Desenho elaborado por Lívia. Coqueiros, em resposta ao questionamento sobre 'o que você gostaria que tivesse no seu bairro?'

FIGURA 90 - Fotografia feita pelo grupo de Maria Eduarda, Nicolly e Yasmin durante visita ao entorno da escola....... 


\section{SUMÁRIO}

INTRODUÇÃO 19

CAPÍTULO 1: AS CRIANÇAS E A CIDADE..............................................29

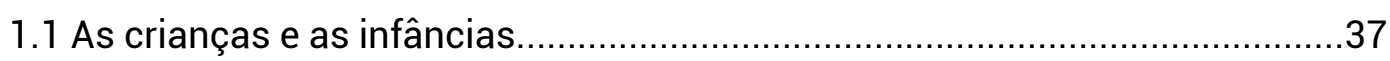

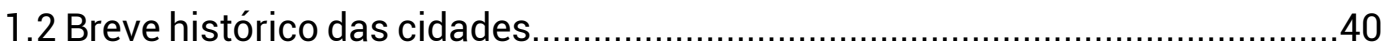

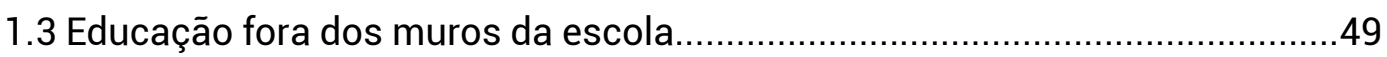

1.4 Projetos com crianças e cidade e cidades com crianças.................................53

1.4.1 Cidade Educadora..........................................................................

1.4.2 A Cidade das Crianças.....................................................................59

1.4.3 Iniciativas em São Paulo................................................................64

CAPÍTULO 2: A CIDADE PERIFÉRICA E SUAS INFÂNCIAS: AS CRIANÇAS DO

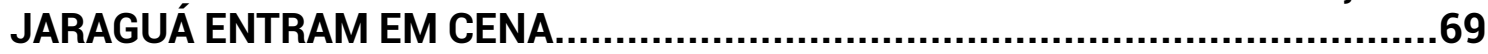

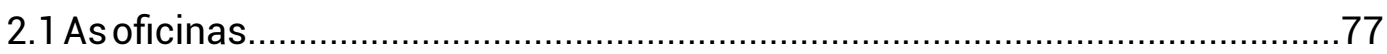

CAPÍTULO 3: O JARAGUÁ E A CIDADE PELOS OLHOS DAS CRIANÇAS.............97

3.1 "São Paulo tem condomínios e prédios ricos com piscinas" - leitura das desigualdades.

3.2 - "No fim de semana eu fui no shopping!" - leitura do lazer, do consumo e da inserção social. 
3.3 - "Aqui não vai ter mais brinquedos?" - leitura dos espaços das infâncias urbanas.

3.4-"Eubrinconoprédiocomosmeusamigos"-leituradosespaçospúblicosversus privados

3.5 - "Eu vim a pépara a escola. Viárvores, prédios, carros, a escola, gente, perua ea moça do doce na frente da escola" - leitura dos afetos e identidades.

CAPÍTULO 4: PROJETOS E PARTICIPAÇÃO: OS DESEJOS DAS CRIANÇAS PARA TRANSFORMAR A CIDADE E O JARAGUÁ....................................................185

4.1 A participação infantil.............................................................................190

4.2 As propostas e os projetos das crianças...............................................202

4.3 Como as crianças podem participar dos espaços públicos urbanos?.........220

4.3.1 Conselho das Crianças........................................................223

4.3.2 Projetação Participada.......................................................22

CONSIDERAÇÕES FINAIS..........................................................231

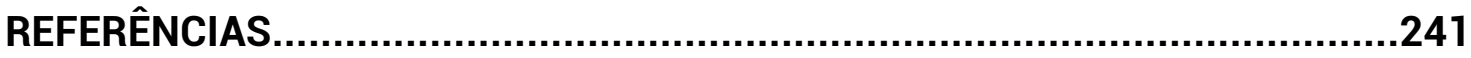

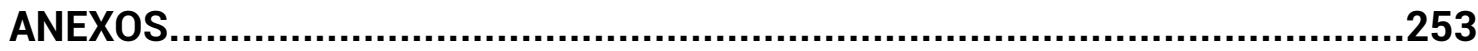




\section{INTRODUÇÃO}

Não há ensino sem pesquisa e pesquisa sem ensino. Esses quefazeres se encontram um no corpo do outro [...]. Pesquiso para constatar, constatando, intervenho, intervindo educo e me educo. Pesquiso para conhecer o que ainda não conheço e comunicar ou anunciar a novidade.

Paulo Freire ${ }^{2}$ 


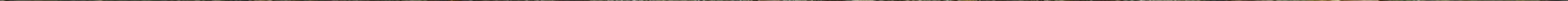


FIGURA 01 [verso]

Fotografia feita pelo grupo de Deyvid, Lívia e Pyetra durante visita ao entorno da escola. Máquina fotográfica digital, setembro de 2016.

Fonte: Arquivo pessoal, 2016. 
${ }^{3} \mathrm{~A}$ metodologia da charrette inspira-se nos processos realizados, no século XIX, nas Escolas de Belas Artes de Paris, nos quais os estudantes de arquitetura ficavam durante uma semana imersos na elaboração de um projeto complexo; ao final desse prazo, uma charrete (a rigor, um carrinho de mão) passava entre eles recolhendo os projetos finalizados. $\mathrm{Na}$ atualidade, essa metodologia pode ser entendida como atividades projetuais de imersão, capazes de envolver diferentes disciplinas para a resolução e a elaboração de um projeto.

${ }^{4}$ Para mais informações consultar VICENTE, Paula Martins. A Escola como um Parque e o Parque como uma Escola: aprendizado através da paisagem. Trabalho Final de Graduação, Faculdade de Arquitetura e Urbanismo da Universidade de São Paulo, FAUUSP. São Paulo, 2012
Diante dos conflitos e disputas de usos e apropriações que ocorrem, atualmente, nas cidades, surge uma pergunta de grande importância quando pensamos em sociedades e espaços mais democráticos: onde estão os olhares e os desejos infantis?

A partir de uma pequena ou quase nula participação das crianças na transformação e nas políticas públicas que envolvem os espaços urbanos, essa pesquisa nasceu com o intuito de investigar as relações que se constroem em suas interações com a cidade, sobretudo, por meio dos espaços livres públicos. Nesse sentido, são possíveis inúmeras leituras, caracterizações, escolhas de territórios e análises urbanas a serem feitas, que perpassam as mais distintas escalas e abordagens. Naquilo que tange o universo infantil, pode-se optar por: faixas etárias maiores ou menores, sendo os bebês ainda mais invisíveis dentro da estrutura urbana quando comparados às crianças que se aproximam da adolescência; meninos e/ou meninas, entendendo as diferenças de possibilidades e usos permitidos em função de uma classificação sexista desde a infância; contextos de inserção social e cultural que constroem pontos de vista e experiências distintas, dentre outros tantos aspectos.

Essa pesquisa não se iniciou com o curso de mestrado e não pretende encerrarse com as reflexões aqui levantadas. Desde os anos finais da graduação, a temática da infância tem ganhado grande destaque nas investigações da pesquisadora, integrando-se as temáticas de arquitetura, urbanismo e paisagismo, dentro das premissas da elaboração de projetos participativos. 0 estudo realizado para o trabalho final de graduação, por exemplo, propôs a reformulação do projeto do Parque Municipal Pinheirinho d'Água a partir das demandas apontadas em uma charrette ${ }^{3}$ realizada na Escola Municipal Deputado Rogê Ferreira, também no Jaraguá. Dessa experiência, participaram cerca de 1200 crianças que elaboraram mais de 1700 propostas para a transformação do parque em um espaço que pudesse ser melhor aproveitado e utilizado pela escola ${ }^{4}$.

A partir desse conhecimento que vem se construindo, o presente trabalho busca um aprofundamento nos papéis políticos das crianças, a fim de trazê-las na 
condição de atores sociais para a discussão e a participação nos espaços públicos, sobretudo em contextos periféricos, como é o caso do distrito do Jaraguá, no Município de São Paulo. Nesse sentido, a aproximação com os campos da Educação, Pedagogia, Sociologia, Antropologia e Psicologia permitiu a visualização de alguns caminhos, ainda a serem construídos juntamente com a Arquitetura e o Urbanismo, para trabalhar a complexidade das infâncias urbanas na construção e na produção da cidade.

As leituras e as relações que as crianças estabelecem nos espaços livres públicos, sobretudo nas periferias paulistanas, foram os pontos centrais para a realização dessa pesquisa. A partir deles, a metodologia utilizada buscou as manifestações infantis através de oficinas que envolveram diferentes formas de expressão para conhecer a cidade e os projetos elaborados para ela, a partir do olhar das crianças. Esse processo permitiu-se ser mais flexível, incorporando as contribuições vindas dos próprios meninos e meninas através daquilo que eles apontavam como respostas aos temas trabalhados, propondo um diálogo entre as teorias e a prática realizada e observada.

Diante das reflexões decorrentes das atividades propostas, esse trabalho também fortalece-se enquanto um processo de contribuição para estudos de temáticas relacionadas as questões da infância dentro dos espaços urbanos. Não se busca encerrar ou contemplar aqui todas as variáveis possíveis dentro dessa abordagem, mas alimentar novos debates, inquietações e possibilidades para outras práticas de valorização e colocação das crianças em seus espaços de direito dentro da cidade.

Nessa perspectiva, durante os encontros e trocas com os meninos e meninas participantes das oficinas que compõem essa pesquisa e de outras experiências que foram realizadas durante a elaboração desse trabalho, as crianças assumiram papéis centrais nas reflexões sobre as possíveis formas de participação e percepção infantil na cidade. Apesar do enfoque de interesse estar centrado na leitura de uma área na periferia do Município de São Paulo, com suas particularidades decorrentes dessa inserção, os temas aqui abordados refletem inúmeras outras realidades semelhantes dentro da cidade e do país, nas quais a escuta das vozes infantis, com suas considerações para 
a construção e produção da cidade, é ignorada. Partindo-se das questões colocadas e apontadas na escala dos bairros e dos espaços cotidianos, busca-se atingir aspectos mais amplos e temas comuns às crianças em suas relações com as cidades de modo geral.

A abordagem da presente pesquisa traz o distrito do Jaraguá e o Município de São Paulo através dos pontos levantados pelas falas e expressões das crianças participantes e, também, pesquisadoras desse trabalho, que foram consideradas sujeitos e não objetos de estudo. Nesse sentido, São Paulo e o Jaraguá são caraterizados e compreendidos a partir dos olhares e percepções infantis, que podem indicar leituras muito distintas daquelas vindas dos adultos.

Assim como Beatriz Sarlo (2014) que usa a literatura e a arte para a compreensão da cidade, as manifestações infantis aqui trabalhadas - desenhos, maquetes, fotografias e oralidade - também assumem esse papel, "(...) nunca são utilizadas instrumentalmente, como ilustração, mas em seu caráter de realidade específica, que através de vários mecanismos ativados pela interpretação permite acessos iluminadores a essa outra realidade, a urbana." (GORELIK, 2014, p.XII)

A partir dessas considerações e na intenção de trazer as leituras infantis, juntamente com as teorias que refletem sobre os papéis políticos e sociais das crianças na cidade, este trabalho divide-se em quatro partes, além das considerações finais.

O primeiro capítulo, As Crianças e a Cidade, apresenta uma contextualização teórica da construção dos conceitos de cidade, espaços livres públicos, crianças e infância(s) trabalhados por essa pesquisa. Traça um breve histórico de como as crianças foram se afastando, cada vez mais, dos locais de usos coletivos e públicos, transformando-se em sujeitos privados, sob os cuidados e a responsabilidade de apenas alguns setores sociais, como a família e as instituições de ensino. Na contramão dessa abordagem, apresentam-se dois exemplos de projetos, realizados internacionalmente - Cidade Educadora e A Cidade das Crianças -, que colocam em pauta questões para 
a discussão das infâncias nos cenários urbanos. Outros projetos desenvolvidos na escala local também são apontados como iniciativas, ainda que pontuais e localizadas, que buscam uma maior apropriação da cidade pelas crianças.

O segundo capítulo, A cidade periférica e suas infâncias: as crianças do Jaraguá entram em cena, traz o percurso metodológico realizado pelas oficinas e atividades elaboradas por essa pesquisa. São apresentados os sujeitos e as etapas que subsidiaram as interpretações posteriores e a construção das reflexões que compõem esse trabalho.

O terceiro capítulo, 0 Jaraguá e a cidade pelos olhos das crianças, apresenta as percepções infantis sobre seus espaços cotidianos. A partir das produções realizadas foram identificadas cinco leituras possíveis que auxiliaram na interpretação dos bairros de origem e da cidade através dos olhares dos meninos e meninas. Com essas entradas, identificam-se pontos e questões urbanas amplas que atingem diferentes contextos e realidades, mas que marcam, sobretudo e de maneira mais intensa, os cotidianos das crianças moradoras de áreas periféricas em situações semelhantes.

O quarto capítulo, Projetos e participação: os desejos das crianças para transformar a cidade e o Jaraguá, elabora uma reflexão sobre o papel da participação infantil, principalmente na dinâmica urbana, que é capazes de estimular o envolvimento e as manifestações dos meninos e meninas dentro das estruturas políticas e sociais. Além dessa contextualização e discussão, também são apresentadas as propostas e os projetos das crianças participantes da pesquisa, trabalhados dentro da temática dos desejos de transformação urbana. Como forma de visualizar a possibilidade de concretização da participação infantil, são apresentadas duas experiências realizadas pelo projeto A Cidade das Crianças em alguns países, que as colocam como sujeitos atuantes e com seus direitos de cidadãs respeitados para a participação nos espaços públicos. 
Por fim, nas Considerações finais é feita uma síntese dos principais pontos trabalhados, buscando-se uma análise crítica no tocante ao papel do arquiteto nesse processo. Pretende-se contribuir com elementos que possam estabelecer novas possibilidades de pesquisas e não fechar as discussões iniciadas neste trabalho.

Reforçando, novamente, o caráter das crianças como atores sociais e pesquisadoras dentro das atividades aqui elaboradas, convidamos os leitores e leitoras a percorrerem e interpretarem não apenas os textos desenvolvidos, mas também as produções infantis, que são parte e construtoras dessa pesquisa. 


\title{
CAPÍTULO 1 AS CRIANÇAS E A CIDADE
}

\author{
Ah, a rua! Só falam de tirar as crianças da rua. \\ Para sempre? Eu sonho com as ruas cheias delas. \\ É perigosa, dizem: violência, drogas... \\ E nós adultos, quem nos livrará do perigo urbano? \\ De quem eram as ruas? Da polícia e dos bandidos? \\ Vejo por outro ângulo: um dia devolver a rua às crianças ou devolver as crianças às ruas; \\ ficariam, ambas, muito alegres. \\ Paulo Freire
}



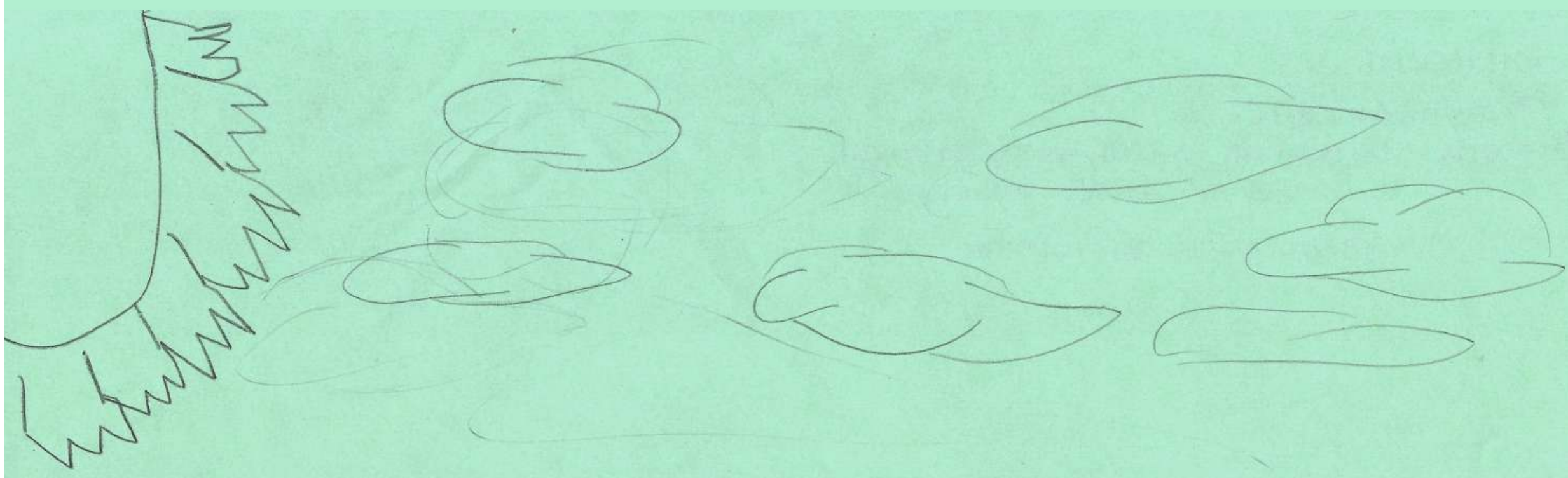

हो

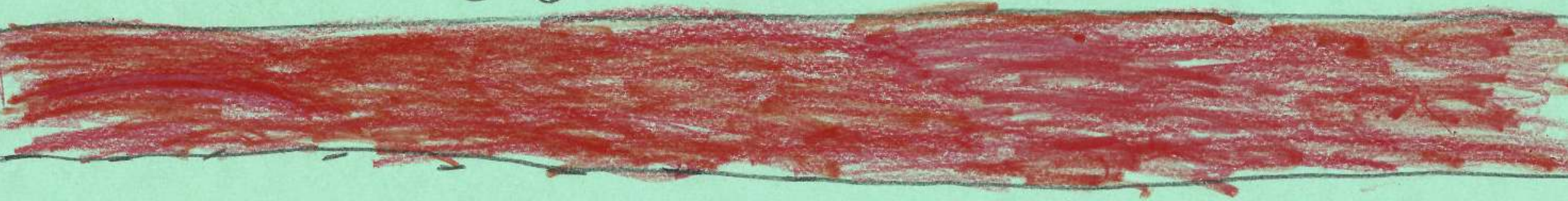


FIGURA 02 [verso]

Desenho elaborado por Guilherme. Resposta dada ao questionamento sobre 'o que você gostaria que tivesse em seu bairro'. Lápis de cor vermelho e grafite sobre papel sulfite na cor verde, $210 \mathrm{~mm} \times 297 \mathrm{~mm}$, outubro de 2016.

Fonte: Arquivo pessoal, 2016 
A cidade é um espaço de disputas: social, econômica e política, onde prevalecem os interesses de atores pertencentes às classes sociais dominantes, excluindo-se de seu meio outras camadas sociais, etárias e culturais.

A cidade pode ser objeto de diversas abordagens: pode ser lida como discurso (como querem os semiólogos e semióticos); pode ser abordada pela estética - ambiente de alienação e dominação por meio da arquitetura e urbanismo do espetáculo; como manifestação de práticas culturais e artísticas mercadológicas ou rebeldes; como legado histórico; como palco de conflitos sociais; como espaço de reprodução do capital e da força de trabalho, entre outras. Essas diferentes ou dispersas formas de ver a cidade certamente tornam mais difícil situá-las como um objeto central estruturador das relações sociais. A mídia do mainstream trata da cidade o tempo todo, entretanto raramente a toma como um produto ou mercadoria que intermedia os conflitos entre as classes sociais. (MARICATO, 2015, p.19)

Embasada nessa leitura e reforçando o caráter de uma produção urbana que favorece os interesses de alguns, em detrimento de outros, podemos considerar que a cidade contemporânea se forma como resultado e expressão das relações sociais constituídas dentro da produção capitalista, que tem na sua materialização espacial uma das principais formas de produção e reprodução do capital.

No entanto, também compartilhamos de outro entendimento, que não exclui esses pontos apresentados, mas enxerga a cidade também dentro de uma construção humana e de seres humanos, como

o lugar onde os desejos podem ganhar forma, onde as pessoas podem se encontrar, onde podem passar e perder seu tempo, encontrar de novo os lugares do passado, preparar o futuro; onde as crianças podem crescer, descobrindo coisas novas, espiando os adultos, admirando os monumentos. Mas também podem aceitar serem corrompidas e apagadas pelos mais baixos desejos de seus habitantes, em geral dos mais poderosos e prepotentes, por suas especulações, seu egoísmo, seus automóveis. Então as cidades apagam os desejos do idoso que quer passear, da criança que quer brincar, do jovem que quer encontrar privacidade e intimidade. (TONUCCI, 2005, p.124-125) 
Na visão de Paulo Freire (2017b) vemos também uma responsabilidade social e coletiva na concepção dessa imagem, na qual

a Cidade somos nós e nós somos a Cidade. Mas não podemos esquecer de que o que somos guarda algo que foi e que nos chega pela continuidade histórica e pelas marcas culturais que herdamos. (p.28)

A Cidade somos nós também, nossa cultura, que gestando-se nela, no corpo de suas tradições, nos faz e refaz. Perfilamos a cidade e por ela somos perfilados. (p.30)

É nessa dicotomia que se forma o conceito de cidade trabalhado por essa pesquisa: um local desigual e excludente, concebido para atender aos interesses daqueles com maiores poderes - políticos e econômicos - que acaba por restringir seus usos e apropriações; mas também um lugar de possibilidades de desenvolvimento e estabelecimento de relações entre seus habitantes, sobretudo para aquelas classes mais vulneráveis, como é o caso das crianças, que sendo expressão daquilo que somos, nos coloca em um processo de construção desse espaço e construção de nós mesmos.

Segundo Maricato (2013), a cidade é o principal lugar de reprodução da força de trabalho e também onde as desigualdades sociais e de renda podem assumir proporções elevadas.

Boas condições de vida dependem, frequentemente, de políticas públicas urbanas - transporte, moradia, saneamento, educação, saúde, lazer, iluminação pública, coleta de lixo, segurança. Ou seja, a cidade não fornece apenas o lugar, o suporte ou o chão para essa reprodução social. Suas características e até mesmo a forma como se realizam fazem a diferença. (MARICATO, 2013, p.20)

Quando falamos da cidade como um lugar de conflitos, apontamos aí as disputas por melhores condições de vida urbana e de usufruto desse espaço enquanto um direito, onde aparecem também as crianças, versus aqueles que a encaram como uma mercadoria, produzida para atender aos interesses do mercado imobiliário e gerar lucros para uma camada social detentora de poder decisório e econômico, que 
${ }^{5}$ Para mais informações, consultar SANTOS, Milton. Espaço e método. São Paulo: Nobel, 1985.

A natureza do espaço: técnica e tempo, razão e emoção. São Paulo: Hucitec, 1996.

Da totalidade ao lugar. São Paulo: EDUSP, 2005 determina, através de lógicas convenientes ao mercado, sua forma de produção. Nesse cenário, coexistem trechos urbanos que se realizam na formalidade e na legalidade com aqueles formados de maneira segregada nas periferias e na ilegalidade, sendo que um alimenta o outro para que sejam mantidos.

Nessa perspectiva, temos a cidade também como um lugar de diversidade e expressão histórico-cultural, na qual as memórias urbanas vão sendo determinadas por processos sociais e políticos, selecionando lugares, fatos e categorias a serem valorizados e preservados, enquanto outros são apagados. É nesse campo de interesses diversos e conflituosos que as crianças se apresentam como uma camada, ainda que tímida, a lutar e ocupar, junto aos demais cidadãos, os espaços da cidade.

Dentro da temática urbana abordada por esse trabalho, daremos maior ênfase para os espaços livres públicos - ruas, calçadas, largos, praças, parques - fazendo-se necessário pontuar o que é entendido por essa denominação.

Desse modo, tomando-se como base a estrutura e a construção teórica elaboradas por Queiroga (2012) e subsidiadas por outros autores, estabeleceu-se a conceituação desses elementos que serão tratados ao longo da pesquisa, visando facilitar o entendimento sobre as reflexões que serão aqui apresentadas.

Queiroga(2012) desenvolve o conceito de espaço referenciando-se na concepção físico-geográfica e de instância social que o geógrafo Milton Santos ${ }^{5}$ apresenta em sua obra, ou seja, é a união dos objetos físicos e geográficos - naturais ou não - com os aspectos sociais, econômicos, políticos e culturais de cada sociedade. Dessa maneira, cada espaço é repleto de significados que se alteram no tempo e com as pessoas; quem lhe atribui valor é a sociedade e, se essa se modifica, os valores também mudam.

Quando se diz espaço livre, entende-se que é o espaço humano, na visão miltoniana, que dentro da cidade é livre de qualquer tipo de edificação, conforme defıne a arquiteta paisagista Miranda Magnoli:

O espaço livre é aqui entendido como todo espaço (e luz) nas áreas urbanas e em seu entorno, não-cobertos por edifícios. A amplitude que 
se pretende diz respeito ao espaço e não somente ao solo e a água, não-cobertos por edifícios [...] Por esse entendimento de espaço livre (todo solo e toda água não-cobertos por edifícios) o vínculo do espaço é fundamentalmente de localização em relação aos edifícios, isto é para com as pessoas que os ocupam, em circulação ou permanência. 0 enfoque de espaço livre enquanto objeto de desenho só é relevante desde que analisado em face das atividades e necessidades do homem urbano.

Assim sendo, o espaço livre de edificações e de urbanização constituise em um contínuo cuja distribuição deve ser tal que propicie o enriquecimento das atividades do homem urbano. (MAGNOLI, 2006, p.202-203).

Referenciando-se na construção teórica de espaço público de Queiroga (2012), que se embasa nas conceituações de Hannah Arendt ${ }^{6}$ e Jurgen Habermas ${ }^{7}$, podemos dizer que os espaços públicos, além de serem de propriedade pública, são

espacialidades da esfera pública como as práticas espaciais da vida em público, da esfera pública (geral ou estrita). São as apropriações públicas dos espaços, independentemente de se realizarem em propriedades públicas ou privadas. (QUEIROGA, 2012, p.64)

Isto posto, por espaço livre público, considera-se o espaço de construção física e humana, livre de edificações, mas existente devido a sua antítese de presença, que é de propriedade pública e de manifestação da vida em público; lugar esse que é um campo de memórias individuais e coletivas, sentimentos, trocas e conhecimentos, onde se dá o contato humano e acontecem as experiências em público.

Dessa forma, o espaço livre público na cidade se potencializa enquanto espaço do cotidiano, vivido por todos que diariamente são afetados por essas relações sociais.

$\mathrm{Na}$ experiência humana, o espaço nunca é um vazio. Ele é sempre o lugar repleto de significados, lembranças, objetos e pessoas, que atravessam o campo de nossa memória e dos nossos sentimentos, desperta tristezas e alegrias, prazeres e dores, tranquilidade e angústias.

Para qualquer ser vivo o espaço é vital, não apenas para a sobrevivência,
6 Para mais informações, consultar ARENDT, Hannah. A condição humana. $5^{a}$ ed. Tradução de Roberto Raposo. Rio de Janeiro: Forense Universitária, 1991.

${ }^{7}$ Para mais informações, consultar HABERMAS, Jurgen. Mudança estrutural da esfera pública: investigações quanto a uma categoria da sociedade burguesa. Tradução de Flávio Kothe. Rio de Janeiro: Tempo Brasileiro, 1984. 
mas sobretudo para o seu desenvolvimento. Para o ser humano, o espaço além de ser um elemento potencialmente mensurável, é o lugar de reconhecimento de si e dos outros, porque é no espaço que ele se movimenta, realiza atividades, estabelece relações sociais. (LIMA, 1995, p.187)

É nesse espaço urbano, que não serve apenas como suporte das relações sociais, mas constitui-se e forma-se como instância social, envolvendo processos políticos e culturais, que se criam territórios demarcados por diferentes poderes econômicos, políticos e populares - nos quais as crianças se inserem.

\subsection{As crianças e as infâncias}

A criança a ser considerada nessa pesquisa é a criança de hoje: com sua necessidade de ser ouvida, respeitada em suas particularidades e conhecimentos e que é capaz de participar da vida pública da cidade.

Essa criança tão distante de nós e tão necessitada de nossa ajuda e de nosso afeto, difícil de ouvir e de compreender, possui em si uma força revolucionária: se estivermos dispostos a colocarmo-nos na altura dela, a lhe dar a palavra, ela será capaz de nos ajudar a compreender o mundo e nos dará a força para a mudança. (TONUCCI, 2005, p.207)

Para caracterizar as crianças participantes dessa pesquisa, faz-se necessário uma breve apresentação da perspectiva na qual nos embasamos para o desenvolvimento do trabalho e a construção dos capítulos seguintes.

De acordo com Qvortrup (2014), entende-se por criança, um sujeito individual, nos termos de disposições psicológicas e biológicas, cujos valores se alteram ao longo de cada infância individual. Por crianças, compreende-se uma pluralidade ou coletividade de crianças, mais ou menos coesa. Por infância, define-se em termos sociológicos uma categoria permanente, um período específico, ao qual pertencem as crianças; 
ainda que elas cresçam e se tornem adolescentes e adultos, a infância continuará a existir composta por outras crianças, sendo resultado da ação de parâmetros sociais - econômicos, políticos e culturais. A "infância sociológica é muito mais suscetível a mudanças históricas, enquanto a dinâmica da infância individual pode ser encontrada no desenvolvimento da personalidade." (QVORTRUP, 2014, p.25)

Nesse sentido, entendendo a infância como uma construção social, que se forma pautada na pluralidade de cada sociedade, é válido também falarmos em infâncias, se referindo a essa categoria como uma variável social que se articula à diversidade de vida das crianças, considerando-se suas multiplicidades de classes sociais, gênero, pertencimento étnico e cultural, que não representam uma concepção única. As infâncias são construções tanto estruturais quanto culturais. (JAMES; PROUT, 1990 apud OLIVEIRA, 2017)

As crianças sempre existiram, mas a infância como classificação social só começou a constituir-se a partir dos séculos XVII e XVIII. Foi apenas a partir da década de 1990 que os estudos ultrapassaram o confinamento dos campos médicos, psicológicos e pedagógicos, para considerar o fenômeno social da infância como uma categoria autônoma, com o estabelecimento de relações sociais. (SARMENTO; PINTO, 1997)

Embasada nos estudos da Sociologia da Infância e na contramão de uma visão da criança enquanto tábula rasa, menores, menos competentes ou ainda seres agregados à sociedade dos adultos, essa pesquisa as concebe como atores sociais plenos. São, portanto, produtoras de cultura, sujeitos capazes de interagir em sociedade, de atribuir sentido às suas ações e com direito à participação social. Desse modo, não são encaradas como seres em devir, mas sujeitos completos.

Para Sarmento e Pinto (1997), quando reconhecermos esses papéis sociais e culturais da infância, há a constatação e a valorização da capacidade que as crianças têm de produzirem símbolos e constituírem representações, crenças e organizações próprias, isto é, as culturas da infância.
8 JAMES, A.; PROUT, A. (orgs.). Constructing and reconstructing childhood Contemporary issues in the sociological study of childhood. Londres: The Falmer Press, 1990. 
Da mesma maneira que se constrói a ideia de infâncias como uma pluralidade, também não é possível pensar em uma única cultura da infância, já que também se caracterizam pela heterogeneidade, com diferentes realizações de produção de sentido e da pluralidade dos sistemas de valores, crenças e representações sociais.

As crianças são consideradas, ao mesmo tempo, produtos e produtoras dos processos sociais, articulando-se com eles de maneira geral, modificando-os com suas presenças e ações, mas também se transformando e se formando a partir deles. 0 universo infantil não se desenvolve isolado do mundo adulto, eles se complementam, e as crianças formulam seus sentidos e interpretações do mundo a partir das experiências que as rodeiam.

A diferença entre as crianças e os adultos não é quantitativa, mas qualitativa; a criança não sabe menos, sabe outra coisa.

[...] os significados elaborados pelas crianças são qualitativamente diferentes dos adultos, sem por isso serem menos elaborados ou errôneos e parciais. (COHN, 2005, p.33-34)

Dessa forma,

As culturas infantis não nascem no universo simbólico exclusivo da infância, este universo não é fechado - pelo contrário, é, mais do qualquer outro, extremamente permeável - nem lhes é alheia a reflexividade social global.

A interpretação das culturas infantis, em síntese, não pode ser realizada no vazio social, e necessita de se sustentar na análise das condições sociais em que as crianças vivem, interagem e dão sentido ao que fazem. (SARMENTO; PINTO, 1997, p.15)

A partir da consideração das crianças como sujeitos de direitos, suas falas ganham extrema importância no processo de conhecimento de suas culturas e construções de mundo. Ouvi-las, além de ser um aspecto fundamental dentro da consideração de seus papéis sociais, mostra-se também como um reconhecimento delas enquanto cidadãs. 
Conhecer as crianças a partir delas mesmas e através de suas falas nos possibilita acessar e interpretar seus mundos e modos de vida, que muito se distinguem dos adultos. Seus olhares sobre determinados assuntos ou aspectos nos permitem revelar fenômenos sociais ocultos aos adultos, que carregam vivências, vícios e modos de encarar a realidade, muitas vezes, contaminado pelo pessimismo e pela rigidez imposta pelo mundo urbano. Dessa forma, acriança é capaz de revelar aquilo que o adulto desaprendeu ou deixou de ver.

\subsection{Breve histórico das cidades}

Sem a intenção de fazer aqui uma retrospectiva histórica das cidades, para os objetivos dessa pesquisa interessa-nos retomar apenas alguns aspectos urbanos vindos a partir das mudanças ocasionadas com a modernidade, que trouxeram alterações significativas e estruturais para a construção dos espaços urbanos atuais. A partir do histórico das cidades europeias ocidentais da Idade Média e Moderna, as características aqui apresentadas são analisadas como influências que atingiram, em menor ou maior proporção, as transformações urbanas também ocorridas em nossas cidades em períodos posteriores. Importa-nos, sobretudo, analisar os principais pontos que se relacionam com as infâncias urbanas. Importanos, sobretudo, analisar os principais pontos que se relacionam com as infâncias urbanas.

Retomando a origem política das cidades, com base na polis grega e na civitas romana:

Polis é a Cidade, entendida como a comunidade organizada, formada pelos cidadãos (politikos), isto é, pelos homens nascidos no solo da Cidade, livres e iguais, portadores de dois direitos inquestionáveis, a isonomia (igualdade perante a lei) e a isegoria (o direito de expor e discutir em público opiniões sobre ações que a Cidade deve ou não realizar).

Ta politika são os negócios públicos dirigidos pelos cidadãos [...]

Civitas é a tradução latina de polis, portanto, a Cidade como ente público e coletivo. Res publica é a tradução latina para ta politika, significando, portanto, os negócios públicos dirigidos pelo populus 
Podemos dizer que, desde o início das cidades, a política foi fator de grande importância para compreensão das relações entre aqueles que compunham essas sociedades - cidadãos, escravos, mulheres, crianças - e para o entendimento de como esses territórios urbanos se formavam através das decisões políticas.

Atualmente, no entanto, apesar da política continuar presente e ser determinante na construção das cidades, ela passou a ser encarada com aspectos pejorativos e negativos. Pode-se dizer que há três leituras possíveis da política: 1. geral e concernente à sociedade como um todo (leis, costumes, direitos e deveres), a ser seguida ou contestada; 2. reduzida aos especialistas e, portanto, inacessível a todos; 3. perversa e maléfica à sociedade e, por isso, deve ser afastada do amplo alcance. (CHAUÍ, 2000)

Nessa visão da política e da cidade estamos excluindo as crianças. Se a política é entendida como algo perverso, dificilmente vamos querer ver os meninos e meninas, seres 'ingênuos', misturando-se com sua 'sujeira' ${ }^{9}$. Se a cidade se forma social, cultural e politicamente, como vemos as crianças nesse cenário? Como elas podem participar, se são excluídas da política, não têm suas culturas reconhecidas e não são vistas como atores sociais?

Segundo o historiador Philippe Ariès (2006), até os séculos XV e XVI, no início da Idade Moderna, nas cidades europeias, as crianças ainda eram bastante presentes e misturadas aos adultos nas atividades e na vida em público. Com os jogos, as brincadeiras e a participação nas festas populares, ambosocupavam os mesmos lugares urbanos. No entanto, é importante destacar que nessa época ainda não havia uma classificação e um entendimento da infância - o que não significa que as crianças

${ }^{9}$ A escolha do termo 'sujeira' para se referir à política faz menção a uma expressão popular no Brasil que diz que "na política só tem sujeira", se referindo a esquemas de desvios de verbas e outras formas de corrupção praticadas pelos políticos. não existiam ou fossem desprezadas, mas não havia um reconhecimento enquanto uma fase específica da vida. Elas eram tidas como crianças por um período muito breve, apenas enquanto eram consideradas dependentes e indefesas. Assim que completavam cinco ou sete anos, passavam a integrar o mundo dos adultos, assumindo 
aí diferentes papéis.

Para Lima (1995) as festas que aconteciam nas cidades tinham uma função social muito forte, pois serviam para transmitir costumes, tradições, valores e a identidade coletiva, estreitavam as relações entre seus membros, aglutinavam pessoas de várias idades, gêneros e procedências diversas e serviam como um ambiente potencialmente rico para as crianças. Tanto as festas quanto as brincadeiras e os jogos se davam nos espaços públicos e "a rua, mais ainda que a praça, era o lugar das crianças por excelência." (LIMA, 1995,p.184)

Nesse contexto, as crianças gozavam de grande liberdade e apropriação dos espaços livres públicos, ocupando-os juntamente com os cidadãos de diferentes faixas etárias e classes sociais, caracterizando, por si só, essas experiências como formas de aprendizado.

"Mas essa liberdade - positiva sob o ponto de vista do aprendizado cotidiano da realidade -, era sem dúvida cheia de problemas, principalmente relacionados com o sexo e a moral cristã." (LIMA, 1995, p.184) A partir do século XVII até os nossos dias, essa moral evoluiu de maneira bastante complexa, difundindo muitos jogos como perigosos e condenando muitas danças e festas coletivas entre adultos e crianças por seu caráter sexual (ARIĖS, 2006). Dessa forma, cada vez mais, e somados a outras transformações sociais, os espaços públicos reduzem suas funções voltadas aos jogos, danças e festas, passando a adquirir outras finalidades que não à expressão coletiva social.

Será nesse cenário em constante modificação que o aprendizado das crianças junto aos adultos, a transmissão de conhecimento de uma geração para a outra e a participação na família ganham características diferentes, fortalecendo e apontando, cada vez mais, para a importância das escolas e dos colégios dentro da sociedade, separando a infância da vida adulta.

Ariès (2006) apresenta que até a Idade Média, as escolas eram destinadas ao clérigo e não às faixas etárias das crianças, que tinham seus aprendizados construídos, 
fora do ambiente doméstico, junto aos mestres que lhes ensinavam uma profissão ou uma atividade. Será com os moralistas e os educadores do século XVII, que fundam os colégios no fim da Idade Média, que o sentimento de uma infância longa começa a se estabelecer, focada nas práticas de educação por meio de uma formação moral e intelectual e de uma preocupação em isolar as crianças do mundo 'sujo' dos adultos, mantendo-as na 'inocência'. Muito tempo se passou até que as escolas se tornassem instituições especialmente reservadas às faixas etárias menores.

Porém, nem todos os meninos frequentavam esses espaços, muitos ainda permaneciam nos modelos de aprendizado da Idade Média e adentravam a fase adulta precocemente, fato que não representava, obrigatoriamente, o pertencimento a classes sociais mais pobres. Contudo, as meninas continuavam sendo educadas segundo o sistema anterior de aprendizagem doméstica, acessando os equipamentos de ensino apenas no século XVIII e início do XIX. (ARIÈS, 2006)

Com a implantação das escolas e as crianças começando a frequentá-las por um longo período, a infância passa a ser estabelecida, dentro desse intervalo, como uma etapa intermediária entre a curta fase da criança bem pequena (considerada indefesa e dependente) e a vida adulta. Simultaneamente, desenvolve-se também o sentimento de família. Segundo Ariès (2006, p.143), esse sentimento que emerge "nos séculos XVI-XVII, é inseparável do sentimento da infância. 0 interesse pela infância [...] não é senão uma forma, uma expressão particular desse sentimento mais geral, o sentimento da família." A família, através do estabelecimento de afeição e de cuidado entre seus integrantes, transformou-se na medida em que modificou suas relações internas com as crianças, sentindo a necessidade de se constituir em um ambiente com maior privacidade, afastado da ampla abertura dada à vida em público e isolado da grande agitação e do espírito de coletividade que existia nos séculos anteriores.

Juntamente com a escolarização, as crianças deixam de construir seus aprendizados baseados no exemplo e no convívio com os adultos. A classificação dentro de uma faixa etária exclusiva - a infância - e a criação do sentimento de família, 
modificam estruturalmente as sociedades modernas, deixando um legado muito forte para os séculos seguintes e para as demais cidades ocidentais: a transformação social dos espaços urbanos.

Foi no século XVIII, que a vida privada e a intimidade doméstica ganharam força e destaque entre as famílias burguesas, que sentiam a necessidade de se preservar do ambiente público, reservando à sociedade um espaço limitado aquém da vida particular. Como consequência, as casas começam a ganhar outras configurações, com a divisão dos ambientes internos e a criação de áreas externas para atender às novas demandas de isolamento e intimidade que surgiam; a família vai tornando-se, cada vez mais, fechada aos seus membros, seguindo uma retração da sociabilidade, que reforça a intimidade da vida privada em detrimento das relações de vizinhança, amizades ou tradições. Há um esforço para separar-se dos outros para afastar-se da sociedade. (ARIÈS, 2006)

Os progressos do sentimento da família seguem os progressos da vida privada, da intimidade doméstica. 0 sentimento da família não se desenvolve quando a casa está muito aberta para o exterior: ele exige um mínimo de segredo. Por muito tempo, as condições da vida quotidiana não permitiram esse entrincheiramento necessário da família, longe do mundo exterior. Um dos obstáculos essenciais foi sem dúvida o afastamento das crianças, enviadas para outras casas como aprendizes, e sua substituição em sua própria casa por crianças estranhas. Mas a volta das crianças, graças à escola, e as consequências sentimentais desse fechamento da família não bastaram: estavam aí muito longe ainda da família moderna e de sua forte vida interior; a antiga sociabilidade, incompatível com esse tipo de família, subsistia quase que integralmente. No século XVII, constituiu-se um equilíbrio entre as forças centrífugas - ou sociais e centrípetas - ou familiares - que não sobreviveria aos progressos da intimidade, consequência talvez dos progressos técnicos. (ARIĖS, 2006, p.164)

Antes da busca familiar pela privacidade, na Idade Média, as atividades públicas e privadas não tinham separações muito bem marcadas e ocorriam dentro dos grupos de maneira ampla. As relações sociais ocupavam um papel muito importante dentro da 
sociedade e na rua, que era o local ideal das manifestações e encontros em públicos. Fora da vida privada, tudo se passava na rua. A vida coletiva misturava as diferentes idades e classes, sem deixar espaço para a intimidade e para a privacidade.

As crianças, nesse cenário, apesar de não serem identificadas e vistas como uma classe separada dos adultos, tinham funções sociais dentro do grupo e podiam desfrutar da cidade e das relações de maneira irrestrita. Ao mesmo tempo em que, a partir do século XVII, elas começam a ganhar reconhecimento, cuidados diferenciados e saem do anonimato, perdem seus papeis sociais anteriores e o direito de usufruir dos espaços urbanos com liberdade.

Dessa época em diante, até o século XIX, as crianças foram gradativamente sendo alijadas do convívio com os adultos e do espaço urbano. As ruas passaram a ser vistas como o local da perdição da inocência, da vadiagem e de risco. Por isso, era preciso separar as crianças das famílias daquelas crianças da rua (os "menores").

Não eram mais livres, umas das outras, pois o novo preceito da educação infantil evoluía para uma disciplina rigorosa, dentro das habitações e das instituições. (LIMA, 1995, p.184)

Com a necessidade de maior isolamento das famílias, da mudança e da redução da sociabilidade, acrescidas das transformações advindas dos processos de industrialização e do incremento da população urbana, a partir dos séculos XVIII e XIX, as cidades e os espaços livres públicos se modificam, assumindo aspectos de funções especializadas, opostas às possibilidades de ocupações, relações sociais e atividades coletivas públicas realizadas anteriormente de maneira ampla e espontânea.

Ainda que a cidade estivesse se transformando e abrigando outros usos em decorrência da chegada das indústrias e dos veículos automotores, até a primeira metade do século $X X$, o espaço urbano ainda possibilitava o encontro e as trocas entre os cidadãos - adultos e crianças - mesmo que de uma maneira muito distinta do que aquela apresentada anteriormente, posterior ao século XVII.

Após a segunda metade do século XX as áreas urbanas vão, cada vez mais, 
especializando-se e fragmentando-se, com o surgimento de novos espaços para abrigar os usos públicos, anteriormente localizados nas ruas, fato que auxiliou no processo de segregação e especulação do solo urbano. "Nesse contexto, as crianças constituem o segmento mais frágil da população e, por isso mesmo, simples espectadores das mudanças boas ou más que ocorrem à cidade e aos seus moradores, agora transformados em meros produtores e ocupantes." (LIMA, 1995, p.184)

A partir daí a cidade vai deixando de ser o lugar do encontro e das trocas e começa a desenvolver-se um interesse pelo estabelecimento de locais especializados para cada função e público alvo. Essa mudança no papel e nas funções urbanas permite uma transformação dos espaços públicos em áreas de perigo e desconfiança. Antes, a cidade era o lugar fundamental do encontro e, apesar da existência de riscos, não se excluía de utilizá-la com ponto primordial para as trocas e as brincadeiras coletivas. Hoje, a casa (o espaço privado) é vista como um lugar de grande segurança, tornando-se autossuficiente e alimentada pelas novas tecnologias e acessos remotos, se contrapondo à cidade. (TONUCCl, 2009)

$\mathrm{Na}$ manutenção dessa transformação que renuncia os espaços públicos e favorece a mobilidade por meios de transportes individuais, ocorre também um afastamento da escala humana e um privilégio, cada vez maior, aos automóveis, com obras urbanas para a ampliação de seus locais de circulação em detrimento da redução de áreas para os cidadãos. Há uma inversão de prioridades, privilegiando os carros em detrimento dos pedestres, incluindo-se aí, sobretudo, as crianças. Ao optarse por governar uma cidade a partir dos parâmetros do homem, adulto, trabalhador e motorista, desprivilegia-se e exclui-se os demais cidadãos que não pertencem a essa categoria, delegando-Ihes as atividades e os espaços privados.

A redução ou a retirada das crianças dos espaços públicos urbanos é decorrente de uma transformação cultural, o que não significa, necessariamente, que não há mais crianças ocupando esses espaços, mas que ocorreu uma mudança social impulsionada, sobretudo, pela transformação urbana. Tal alteração advém da industrialização e da 
presença massiva de automóveis nos espaços públicos de uso coletivo, reduzindo as áreas ocupadas pelo lazer e pela convivência entre os cidadãos, favorecendo a criação de locais reservados para essas atividades.

No mesmo século em que as crianças ganham destaque nos estudos direcionados a elas e têm seus direitos oficializados através de convenções e leis Convenção sobre os Direitos da Criança, do Fundo das Nações Unidas para a Infância (UNICEF), e do Estatuto da Criança e do Adolescente (ECA), no Brasil - a cidade tornase um local de insegurança, afastando-as de seus espaços públicos.

Hoje, em uma sociedade ocidental e moradora de grandes centros urbanos, como é o caso de São Paulo, vemos um grande distanciamento e uma especialização da infância, ausentando as crianças das relações sociais mais amplas - fora dos círculos familiares e escolares - e dos lugares de uso comum a todos os cidadãos, como são os espaços livres públicos urbanos. Não há a constituição nem o interesse da classe dominante em criar condições urbanas que sejam atrativas para as crianças, pois isso poderá tornar a cidade mais democrática e acessível aos diferentes atores que atualmente então escondidos nos ambientes privados. Intervenções que possibilitam o uso dos espaços livres de maneira mais igualitária, muitas vezes, se limitam a ações pontuais que não atingem a extensão territorial de modo a configurar-se como uma política pública.

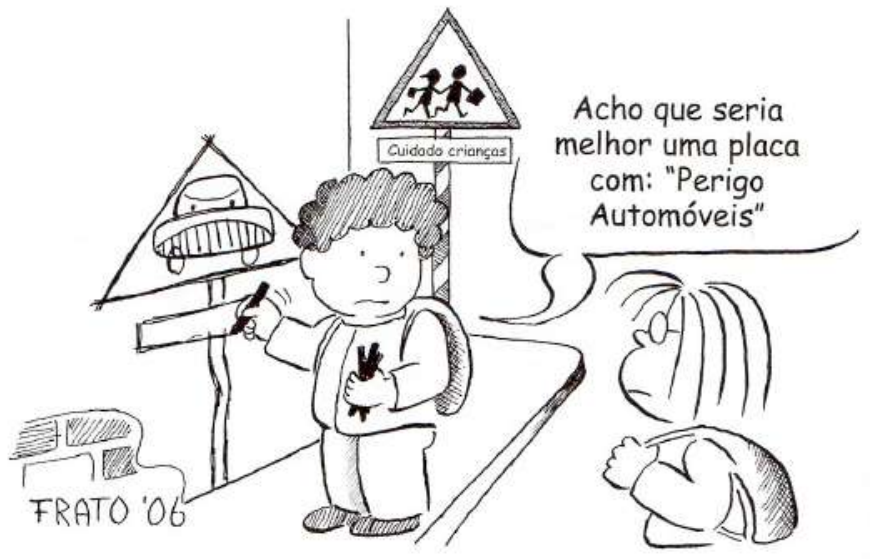


Nesse cenário, cabe uma pergunta fundamental para entender a relação das crianças com a cidade: quais são os espaços que permitimos e concedemos a elas em São Paulo e no mundo, para que ocupem, pertençam e interfiram? Nesse questionamento, cabe destacar não apenas uma relação com os espaços construídos, mas também como essas crianças são vistas dentro da sociedade e das políticas públicas e, não apenas no Município de São Paulo.

Para que as crianças possam exercitar seu direito ao jogo, as cidades devem mudar, renunciando a algumas características estruturais e a alguns comportamentos que tornam impossíveis esta experiência fundamental para um crescimento correto dos cidadãos menores. Em primeiro lugar, há de se devolver aos cidadãos o espaço público, o que significa que as calçadas, as ruas, as praças e os parques não podem estar nas mãos dos automóveis que os ocupam ou transitam por eles; e os espaços não podem ser separados e especializados, porque se são exclusivos para usos das crianças ou para idosos, deixam de ser públicos. Os espaços devem estar abertos as necessidades e as oportunidades de todos os cidadãos e, especialmente daqueles menores e mais fracos. (TONUCCl, 2006, p. 66, tradução nossa).

Não é possível pensar na construção de uma política consistente para atender as demandas das crianças e dos demais cidadãos, se essa for planejada apenas dentro de uma estruturação partidária, que muda com a troca de governo. É preciso pensar e planejar uma política de Estado que seja permanente independente da orientação partidária daqueles que estão na administração pública temporariamente. Mas será que estamos dispostos a tornar as cidades mais democráticas e inclusivas, ainda que isso represente a perda de alguns privilégios do mundo adulto e utilitário de automóveis?

A criança é considerada um indicador ambiental sensível: se em uma cidade são vistas crianças que jogam e passeiam sozinhas, significa que a cidade está saudável; se não é assim, a cidade está enferma.

Uma cidade onde as crianças estão pelas ruas é uma cidade mais segura para as crianças e também para todos os cidadãos. (TONUCCl, s.d., p.3-4, tradução nossa). 


\subsection{Educação fora dos muros da escola}

"Ninguém educa ninguém, ninguém se educa a si mesmo, os homens se educam entre si, mediatizados pelo mundo." (FREIRE, 2017a, p.95)

Ao analisarmos essa frase de Paulo Freire dentro da reflexão sobre a interação das crianças com a cidade, estamos propondo enxergá-las como sujeitos de seus processos educativos, que se constroem com e a partir das relações estabelecidas com o mundo e com as outras pessoas. Com base nesse pensamento, também podemos levantar dois pontos importantes para análise: educação informal e educação integral, reconhecendo a cidade como meio de educação, desenvolvimento e construção social.

Por educação informal, entendemos:

toda experiência educacional que acontece no decorrer de nossa vida, decorrente de processos espontâneos, naturais e socioculturais, desde os primeiros dias da nossa existência. Refere-se às aprendizagens que trazemos de casa, às experiências que vivenciamos nas ruas, no cotidiano de nossas atividades profissionais, no contato com outras pessoas, nas nossas leituras de livros, de jornais, de diversos escritos e obras literárias. Nas conversas informais que temos com as pessoas com as quais nos relacionamos, nas nossas atividades de lazer, de consumo etc., também nos educamos, mas sem que haja uma intencionalidade pedagógica [...] (PADILHA, 2007, p.92)

Como educação integral, superando o que está previsto nos artigos 34 e 87 da Lei de Diretrizes e Bases da Educação Nacional (LDB) - Lei n 9.394, de 20 de dezembro de 1996, que prevê a progressão ampliada da permanência do aluno na escola e o aumento dos turnos escolares de ensino fundamental para regimes de tempo integral - , entendemos que é a expansão das possibilidades de se educar, se formar e se desenvolver enquanto cidadão em contato integral com o mundo, também e inclusive, através da educação informal e, sobretudo, na cidade.

Acreditamos que uma educação que se diz integral e informal deve oferecer oportunidades para que os processos educativos e de formação ocorram também 
fora das escolas e sem a necessidade exclusiva de professores, mas na presença e em contato com sujeitos que assumam papéis de educadores durantes os processos de aprendizagem que ocorrem ao longo da vida. Assim como Paulo Freire (2016), defendemos o processo educativo como uma prática dialógica, de autonomia e de humanização, na qual educando e educadores são capazes de construir o aprendizado e de trocarem de papéis, constantemente, dentro desse processo. "Nas condições de verdadeira aprendizagem os educandos vão se transformando em reais sujeitos da construção e da reconstrução do saber ensinado, ao lado do educador, igualmente sujeito do processo." (FREIRE, 2016, p.28)

Essa educação que ocorre do lado de fora dos muros da escola tem uma importância muito grande no desenvolvimento e na formação infantil, daí a relevância em estudar como se dão as relações entre as cidades, as sociedades e as crianças, a fim de buscar uma real integração entre todas as partes, de modo a concretizar os processos de educação integral dentro da educação informal realizada nos espaços urbanos.

Ao refletirmos sobre a educação informal e a educação de maneira integral no mundo, não estamos apontando para a desvalorização e a falta de importância da escola enquanto entidade de ensino; muito pelo contrário, ela merece ser qualificada e transformada dentro dos aspectos que se identificam deficitários. Porém, não é esse o escopo desse trabalho, mas sim pensar em outras formas de entender a dinâmica da cidade no que se refere à interação com seus cidadãos e, especificamente, com as crianças.

Na área educacional no Brasil, recentemente, observamos um retrocesso do país através de projetos que estimulam o afastamento de crianças e de adolescentes das discussões e da formação de uma consciência política. Nesse contexto, podemos citar as propostas da Escola sem partido ${ }^{10}$, que sendo um projeto de abrangência para todas as instituições de ensino fundamental e médio, atinge e compromete diretamente os processos de formação de autonomia dentro da aprendizagem e da participação
10 Segundo informações presentes na página oficial do projeto, a Escola Sem Partido se diz ser "uma lei contra o abuso da liberdade de ensinar", alegando doutrinação política e ideológica nas salas de aula, ofendendo a liberdade de consciência dos estudantes, o que "instrumentaliza o sistema de ensino com o objetivo de desequilibrar o jogo político em favor de um dos competidores." disponível em <https://www.programaescolasempartido.org/>. Acessado em 13 jan. 2018

No entanto, ao defender essa postura, o próprio projeto se contradiz, pois assume uma postura partidária de manutenção do status quo, colocando "a educação a serviço dos interesses do mercado [...] de uma escola sem pluralidade, sem liberdade, sem diversidade, sem inclusão, sem democracia, uma escola que segrega, que discrimina que reprime." (GADOTTI, 2016, p.153) 
desses cidadãos nas discussões públicas de diversas instâncias - políticas, sociais e urbanas.

A escola tem um papel muito importante na formação das crianças, não apenas como instituição educacional, mas também como locais de troca entre seus pares e com os adultos, porém não se pode negar a importância da cidade na aprendizagem e na experiência humana desde os primeiros anos de vida, onde a brincadeira assume um papel muito importante.

Antes que uma criança entre pela primeira vez em uma sala de aula, as coisas mais importantes já tiveram lugar: os aprendizados mais importantes, as bases sobre as quais deverão ser construídos todo o conhecimento posterior, ou já foram adquiridas ou dificilmente poderão ser recuperadas. (TONUCCl, 2009, p. 152, tradução nossa)

Antigamente, quando havia maior autonomia e liberdade infantil dentro da cidade, era por meio do contato com seus pares e com os adultos nos espaços públicos que as crianças desenvolviam-se e socializavam, longe do olhar atento dos pais. Hoje, devido à alegação de insegurança presente nesses locais, elas sempre estão vigiadas e na presença de adultos, impossibilitando processos de exploração, descoberta, surpresas e riscos. Os riscos evitados não se limitam apenas aos riscos físicos, mas também social e emocional, que podem gerar problemas para o desenvolvimento da autonomia das crianças, pois elas não se veem capazes de fazer enfrentamentos, exporem suas ideias e o que sentem. (TONUCCI, 2009)

Se a criança não pode explorar, buscar, investigar, dificilmente pode se encontrar frente aos problemas desconhecidos com o desejo de confrontá-los e resolvê-los sozinhos; dificilmente poderá viver a emoção de encontrar novas soluções, não ortodoxas e sem dúvida, eficazes. Piaget dizia que os conhecimentos que não se constroem não servem; mas, se o adulto sempre está presente, dificilmente podese evitar sua ajuda e aceitar suas respostas, suas verdades. A escola se baseia quase exclusivamente na relação entre quem sabe, e por isso ensina, e quem não sabe, e por isso deve aprender. (TONUCCl, 2009, p. 153, tradução nossa) 
Nessa perspectiva, de buscar maior autonomia e apropriação dos espaços urbanos, a educação e o aprendizado são vistos como constantes ao longo da vida e não estão apenas circunscritos dentro das escolas; podem ocorrer também em todas as experiências vivenciadas na cidade. Dessa forma, destacamos a importância em qualificá-la enquanto lugar de direito das crianças e local que possibilita a sociabilidade, a democracia, a equidade, as manifestações políticas e culturais, as trocas e os encontros com seus pares, com os adultos e com o espaço urbano construído.

Segundo Lima (1995, p.183), a "apropriação do espaço pela criança se faz pelo jogo, pela brincadeira, pela simulação e pela encenação que ela inventa e vive, e que através deles vai desenvolvendo o seu conhecimento sobre o mundo concreto, a realidade social e seus papéis". Diante disso, o convívio com a cidade torna-se um elemento de grande importância, possibilitando o desenvolvimento da vida pública e o contato com as construções políticas, sociais e culturais que se dão nos espaços urbanos e na sociedade em que elas estão inseridas, estabelecendo, assim, relações e aprendizados informais que se somam e se complementam à educação formal, construindo-se em um único aprendizado.

Atualmente, devido às transformações ocorridas na cidade, em função de atender as demandas colocadas pelas condições políticas e econômicas dos diferentes contextos sociais, cada vez mais, as crianças têm reduzidos os

espaços para o desenvolvimento e o aprendizado do viver coletivo, da partilha, da solidariedade, das regras traçadas em comum, justamente numa época histórica em que o crescimento demográfico, as crises econômico-sociais e a pluralidade cultural exigem de cada um, a capacidade de saber-se ser humano, isto é, inserido e de atos responsáveis, tanto dos coletivos próximos quanto de uma comunidade internacional. (LIMA, 1995, p.190)

Diante disso, ao longo desse trabalho, serão apontados alguns questionamentos e reflexões sobre quais tipos de cidades estão sendo produzidas para seus cidadãos e quais possibilidades estão sendo retiradas das crianças nos espaços públicos urbanos. 


\subsection{Projetos com crianças e cidade e cidades com crianças}

Como forma de pensar na relação criança-cidade e cidade-criança, na sequência serão apesentados dois projetos de abrangência mundial ${ }^{11}$ - Cidade Educadora e Cidade das Crianças - que trabalham questões urbanas educacionais e possibilidades da atuação infantil nos cenários urbanos.

Além desses dois projetos, também pontuaremos algumas experiências realizadas recentemente no Município de São Paulo, como maneira de refletirmos

${ }^{11}$ Outros projetos, também inseridos no contexto internacional, como o Cidades amigas das crianças, do UNICEF, e o Urban 95, da Fundação Bernard van Leer, também foram levantados, porém, optou-se por não aprofundá-los nesse trabalho, a fim de concentrar a análise na Cidade Educadora e na Cidade das Crianças, por acreditar que eles possibilitaram uma maior aproximação com as reflexões e com os pontos levantados pela pesquisa.
FIGURA 04

Fonte: TONUCCI, 2008

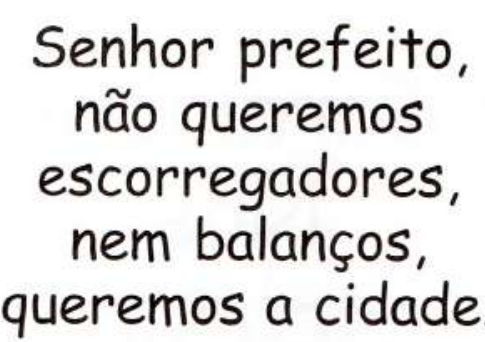
queremos a cidade.
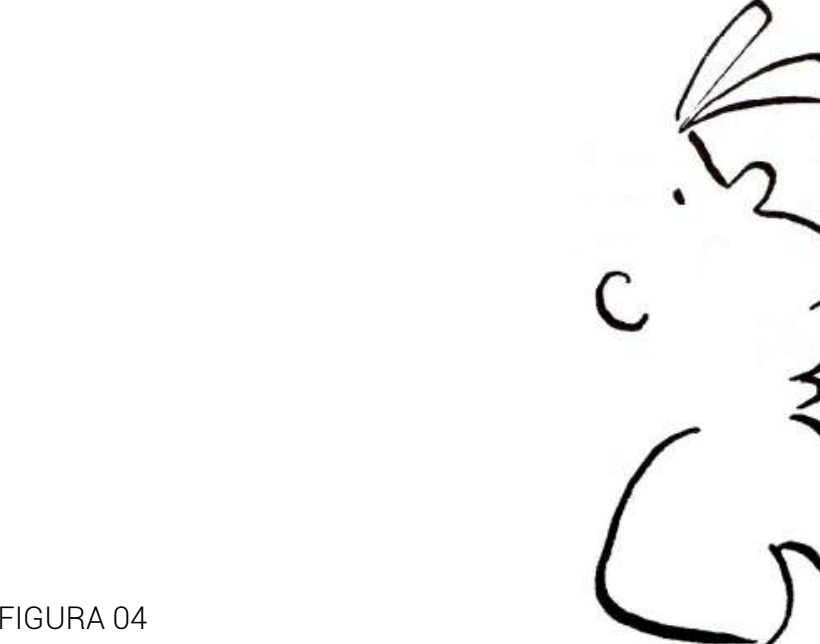

C
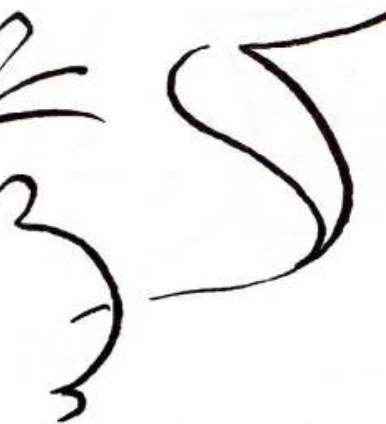

FRATO'O2 
também sobre as ações que se dão nesse território.

\subsubsection{Cidade Educadora}

O conceito de Cidade Educadora, que ganhou destaque e teve início em novembro de 1990, em Barcelona, com o $1^{\circ}$ Congresso Internacional de Cidades Educadoras, dá visibilidade para o caráter educador das cidades, oferecendo elementos para a formação e o desenvolvimento integral de seus habitantes.

A cidade educadora deve exercer e desenvolver esta função paralelamente às suas funções tradicionais (econômica, social, política de prestação de serviços), tendo em vista a formação, a promoção e o desenvolvimento de todos os seus habitantes. Deve ocupar-se prioritariamente com as crianças e jovens, mas com a vontade decidida de incorporar pessoas de todas as idades, numa formação ao longo da vida. (ASSOCIAÇÃO INTERNACIONAL DE CIDADES EDUCADORAS, [2004], p.2).

O projeto educativo de cidade nasce com a ambição de transformar a educação num dos elementos estratégicos do desenvolvimento do meio urbano. (MORALES, 2003)

A Carta das Cidades Educadoras, que foi elaborada no $1^{\circ}$ Congresso Internacional e revista nos Congressos de 1994 e de 2004, traz vinte princípios que deverão ser incorporados aos projetos políticos das cidades que buscam fazer parte da rede. Esses princípios são agrupados em três grandes eixos:

1. O direito a uma Cidade Educadora: engloba seis princípios que colocam o direito a todo cidadão em usufruir de maneira democrática, com liberdade e igualdade da cidade, onde o potencial educativo seja garantido por políticas municipais que promovam a educação formal, não-formal, informal e a diversidade cultural.

2. O compromisso da cidade: aborda seis princípios que visam o oferecimento de equipamentos e serviços públicos para garantir o desenvolvimento dos seus habitantes, com atenção especial às crianças e aos jovens, atendendo as necessidades 
${ }^{12}$ ASSOCIAÇÃO INTERNACIONAL DE CIDADES EDUCADORAS (AICE). Disponivel em: <http://www.edcities.org/>. Acesso em: 11 jan. 2018.

3 CIDADES EDUCADORAS. Disponível em: <http://cidadeseducadoras.org.br>. Acesso em: 11 jan. 2018. de acessibilidade, encontros e lazer, de modo a promover o conhecimento, a aprendizagem e a valorização cultural. A cidade também deve estimular a participação cidadã e a co-responsabilidade no projeto coletivo e educador através do oferecimento de informações e orientações aos seus habitantes.

3. Ao serviço integral das pessoas: traz oito princípios que englobam a responsabilidade da cidade em oferecer e favorecer atividades de formação cidadã visando a participação, a co-responsabilidade e o desenvolvimento dos habitantes no contato com o meio urbano. A cidade também deve conhecer as formas de exclusão e desigualdades a fim de combatê-las.

Atualmente, de acordo com a página oficial na internet ${ }^{12}$, a Associação Internacional de Cidades Educadoras - AICE - conta com 493 cidades associadas, em 37 países. No continente americano, o Brasil é o segundo país com mais municípios associados, ficando atrás apenas da Argentina. No total são 14 cidades brasileiras, de cinco estados diferentes - Rio Grande do Sul, Minas Gerais, São Paulo, Espírito Santo e Ceará - com predominância nas regiões do sul e sudeste: Belo Horizonte (MG); Vitória (ES); Guarulhos, Mauá, Santo André, Santos, São Bernardo do Campo, São Carlos, São Paulo e Sorocaba (SP); Caxias do Sul, Porto Alegre e Santiago (RS) e Horizonte (CE). No entanto, além dessas associações oficiais, o endereço eletrônico do Programa Cidades Educadoras no Brasil ${ }^{13}$ apresenta experiências realizados em diferentes municípios brasileiros que não constam na lista da AICE, tais como: Belém (PA), Natal (RN), Recife $(P E)$, Cuiabá (MT), Nova Iguaçu (RJ), São Sebastião (DF), Joinville (SC), dentre outras.

Os princípios da Cidade Educadora visam quebrar a lógica da educação restrita apenas ao ambiente escolar e institucional, possibilitando que toda a cidade e todos os cidadãos se tornem sujeitos educadores no processo de formação e desenvolvimento de uma comunidade. Nessa perspectiva, a educação também é vista como um elemento presente durante toda a vida de um ser humano e não apenas restrita a uma fase de sua vida.

Na visão do projeto, a educação transcende os aspectos puramente educadores 
e atinge as questões políticas e administrativas, possibilitando que os cidadãos vivenciem e participem da construção do espaço urbano de maneira democrática. Nessa concepção, a cidade se forma também a partir da interação de iniciativas não institucionais e não governamentais - intervenções não-formais - com propostas governamentais decorrentes de ações institucionais - intervenções formais.

Nesse processo de contato entre os diferentes setores da sociedade busca-se que os cidadãos se coloquem de maneira ativa, criando processos de identificação, pertencimento e se sintam co-responsáveis pela construção física, social e cultural da cidade a qual pertençam.

Desse modo, a cidade, por si só, apresenta-se como um elemento educativo e com possibilidades educadoras, seja por afirmação ou por antítese. No entanto, não se pode dizer que todos os seus espaços e projetos são educativos, pois, para isso, eles devem ter tais potenciais acentuados ou problematizados para serem avaliados. Assim sendo, destacamos dois grandes desafios, dentre os muitos necessários de serem alcançados pelas Cidades Educadoras:

1. Pensar na distribuição, nos usos e nas ocupações dos espaços urbanos e dos espaços livres públicos de maneira democrática, requalificando e intervindo em locais de precariedades de habitações e de condições básicas de infraestrutura urbana e equipamentos, a fim de transformar e criar potenciais educativos a serviço de toda a população;

2. Fortalecer a participação consciente e democrática dos moradores através do acesso à informação, ao conhecimento e ao usufruto da cidade com equidade, a fim de se refletir sobre o caráter educativo que ela pode adquirir.

A transformação de uma cidade em Cidade Educadora requer uma interação e um comprometimento entre os poderes municipais e os cidadãos que a habitam e também são co-responsáveis por sua concepção, onde os processos educativos devem deixar de ser vistos apenas como uma atribuição da escola e passar a integrar todos os espaços e os cidadãos urbanos. Desse modo, a escola também deve assumir 
14 PADILHA, Paulo Roberto. Município que Educa: Nova arquitetura da gestão pública. São Paulo: Editora e Livraria Instituto Paulo Freire, 2009.

${ }^{15}$ PADILHA, Paulo Roberto. Educar em todos os cantos: reflexões e canções por uma educação intertranscultural São Paulo: Instituto Paulo Freire / Editora Cortez, 2007. um papel de abertura para os ensinamentos e para a construção cidadã que se dá fora do ambiente institucionalizado.

Como decorrentes das reflexões e das propostas da Cidade Educadora, podemos pensar também naquilo que Paulo Roberto Padilha chama de Município que educa ${ }^{14}$ e Mundo Educador ${ }^{15}$. No caso do Município que educa se propõe a abrangência do município como um todo, com suas áreas rurais e periféricas, não apenas o espaço ou o centro urbano, além de estudar a construção de uma rede de articulações e intercâmbio de experiências para enfrentar os desafios e questões municipais. O Mundo Educador amplia ainda mais a perspectiva da Cidade Educadora e propõe pensarmos no mundo como um território único, onde é necessário planejar ações combinadas e em rede, atingindo uma abrangência e propostas mais democráticas e inclusivas de reflexões e ações.

Apesar das concepções e dos princípios teóricos da Cidade Educadora mostrarem-se democráticos e abrangentes, cabem aqui algumas reflexões sobre o que efetivamente é colocado em ação. No caso brasileiro, por exemplo, observamos uma predominância de projetos concentradas em cidades de grande e médio portes, com limitações a ações efetivadas em territórios locais, que não promovem transformações mais profundas nas relações que estabelecem. 0 objetivo desse trabalho não é aprofundar o estudo e realizar um levantamento de todas as propostas desenvolvidas no âmbito do projeto para o caso brasileiro, porém, ao entrar em contato com algumas atividades realizadas, observou-se o atendimento pontual dessas propostas, sem atingir efetivamente um campo mais amplo ou uma postura de promoção intersetorial das políticas municipais. Dentre os exemplos analisados, o Orçamento Participativo de Porto Alegre, iniciado em 1989, com destaque na década de 1990 e início dos anos 2000 , foi a referência que apresentou maior abrangência no que se refere às políticas urbanas, criando um espaço de discussão e debate da população para decidir qual a maneira e onde aplicar a verba pública municipal dentro dos diferentes setores e áreas da cidade. Ainda assim, cabe aqui o questionamento sobre quem são efetivamente aqueles que participam dessas discussões e com quais conhecimentos e interesses? 
E as crianças, onde e como participam desse processo?

Cláudia Vianna (2004) traz uma questão muito importante para analisarmos aquilo que as propostas da Cidade Educadora consideram como democráticas, que é pensar se existe ou não o efetivo enfrentamento da contradição entre inclusão e exclusão inerentes à cidade, seja ela educadora ou não.

Mantendo-se inerte diante do processo de exclusão não há projeto de cidade educadora que se mantenha, ou melhor, [...] "corre-se o perigo de construir cidades amáveis, bonitas, com grande oferta cultural, mas com grandes níveis de exclusão e segregação social e espacial, o que seria um contra-senso para a proposta de construir cidades mais humanas e harmônicas como pretendem os enunciados da cidade educadora." (VILLA MARTINEZ; MONCADA CARDONA, 1998, p. $103^{16}$ apud VIANNA, 2004, p. 34)

Nas propostas brasileiras analisadas de projetos educadores para as cidades, sobretudo os projetos destinados ao Município de São Paulo, que é objeto de investigação dessa pesquisa, não foi possível observar um real enfrentamento dos aspectos relativos à exclusão e à segregação social, podendo-se cair no grande contrassenso citado anteriormente, já que o atendimento às questões de preconceito e desigualdades sociais são pontos ainda fortemente marcantes de nossas realidades.

Socializar a condição de cidadania não é simplesmente urbanizar materialmente as periferias, fazer mais equipamentos e dar mais serviços. É sobretudo, criar condições culturais para que a povoação menos integrada socialmente viva a cidadania, formule as suas necessidades e existências e utilize realmente a cidade e os seus bens coletivos. (BORJA, 1989, p. $15^{17}$ apud MORALES, 2003, p.107)

Dessa forma, questionamos se São Paulo, apesar de integrar a rede das Cidades Educadoras, é efetivamente uma Cidade Educadora, se convivemos diariamente com problemas tocantes à carência habitacional, de saúde, de saneamento e de condições básicas se sobrevivência?

Será que São Paulo possui um projeto de Cidade Educadora ou será que apenas
16 VILLA MARTINEZ, MII: MONCADA CARDONA, R. Cuidad educadora em Colombia. Santafé/ Medellín: Proyecto La Educación um Propósito Nacional/ Corporación Región, 1998

17 BORJA, I. S. Política socio-cultural y participación ciudadana Madrid: Instituto de Estudios de Administración Local 1989. 
recebe, pontual e isoladamente, projetos educadores? Parece falacioso acreditar que a cidade, diante da realidade em que se encontra e com atendimentos, cada vez mais, ligados aos interesses neoliberais e ao capital exterior, possa ser considerada educadora, com a intenção de ser democrática e incluir todos os seus habitantes nos projetos urbanos.

No entanto, sem desqualificar e sem deixar de observar a importância dos projetos educativos realizados, cabe questionar sobre em que medida essas propostas podem se articular de maneira mais efetiva e sólida na cidade, abrangendo diferentes áreas e cidadãos? Em que ponto esses projetos podem fazer parte de políticas públicas efetivas, para que não sejam colocados apenas como eventos temporários e pontuais, sem garantia de continuidade e ampliação?

\subsubsection{A Cidade das Crianças}

O projeto A Cidade das Crianças (La Città Dei Bambini) iniciou-se em 1991, dentro do Instituto de Ciencia y Tecnologia del Conocimiento (ISTC), do Consejo Nacional de Investigación (CNI), em Fano, na Itália, com a proposta de ser um projeto de motivação política para a colocação da criança como um sujeito ativo e a alteração dos parâmetros urbanos para atender suas necessidades, pois, projetando e administrando uma cidade para elas, todos os demais cidadãos também serão contemplados.

De acordo com o site oficial do projeto ${ }^{18}$, atualmente, a Rede Internacional Cidade das Crianças é composta por cerca de 200 cidades em diferentes países da Europa e da América Latina - Itália, Espanha, Argentina, Uruguai, Colômbia, México, Peru e Chile -, além do Líbano.

O projeto baseia-se não na implantação de novos equipamentos e na

${ }^{18}$ LA CITTÀ DEI BAMBINI. Disponível em:

$<w w w . l a c i t t a d e i b a m b i n i . o r g>$. Acesso em: 04 jan. 2018 crianças, mas na mudança das prioridades da cidade para atender, sobretudo, as 
construção e na transformação dos espaços e da gestão urbana.

Segundo as diretrizes do projeto, a decisão das cidades atuais em privilegiar e construir políticas públicas baseadas no homem, adulto, trabalhador e, geralmente, proprietário e usuário de automóveis como meio de transporte prioritário, afeta e agrava, cada vez mais, o quadro de degradação urbana em relação aos espaços e aos projetos destinados aos demais cidadãos, principalmente para aqueles com maiores carências e necessidade de interação com a cidade, como é o caso das crianças.

Nas últimas décadas, devido à escolha do cidadão adulto e trabalhador como um parâmetro de desenvolvimento e mudança, a cidade perdeu uma das suas características originais, de ser um lugar de encontro e intercâmbio entre as pessoas. Ela renunciou aos espaços públicos, que como pontos de encontro e de troca, eram essenciais. Os pátios, as calçadas, as ruas e as praças adquiriram, cada vez mais, funções associadas ao automóvel e ao comércio, excluindo os cidadãos. A cidade tem desistido de ser um espaço compartilhado e sistêmico, no qual cada parte necessita da outra, para destinar-se aos espaços definidos a determinadas funções e classes sociais diversas, construindo guetos e áreas privilegiadas, esvaziando os centros históricos e dando vida as modernas periferias. As cidades mudaram e tornaram-se um ambiente insalubre para a saúde, devido à poluição atmosférica e sonora, estão sujas e perigosas. (LA CITTÀ DEI BAMBINI, c2009, tradução nossa)

Francesco Tonucci, pedagogo italiano, criador e responsável pelo projeto A Cidade das Crianças, defende que a especialização e a segregação dos espaços urbanos, que coloca como parâmetro o atendimento às demandas do homem adulto, cria uma cidade onde a prioridade é o automóvel e não as pessoas, excluindo todos os demais cidadãos que não pertençam a essa categoria, delegando-lhes as áreas e as atividades privadas.

Tonucci reforça ainda o caráter do projeto em assumir uma postura política e não educacional, ainda que a educação seja uma de suas consequências. Essa decisão aponta para a mudança de comportamento que a cidade adquire ao colocar a criança como um dos cidadãos prioritários, com direito à participação e possibilidades de 
transformação dos espaços urbanos em locais mais inclusivos e democráticos.

Atualmente, a redução das crianças brincando nas ruas e demais áreas públicas dos grandes centros urbanos, reforça a ideia de invisibilidade infantil diante dos olhos adultos e das políticas públicas. Ao nos acostumarmos com essa ausência e ao estranharmos quando meninos e meninas estão ocupando esses locais, fortalecemos a imagem de uma cidade perigosa e desumana. Com pouca presença infantil, as cidades tornam-se mais inseguras, com meios de transportes privados trafegando em velocidades elevadas, muitos espaços se esvaziam e enfraquecem suas funções, a qualidade ambiental é prejudicada e a violência tende a aumentar. Esses locais tornamse também menos democráticos em sua utilização, não acolhendo a diversidade etária que compõe a sociedade. Com a limitação da infância ao ambiente privado, excluemse também as formas de participação infantil, delegando-se essa questão para a responsabilidade e preocupação exclusivas dos pais e não de toda a sociedade, como ela realmente é.

As crianças, ao perderem as cidades, perdem também a possibilidade de viver experiências necessárias para seu correto desenvolvimento, como o jogo, a exploração, a aventura. As cidades, ao perderem as crianças, perdem segurança, solidariedade, controle social. As crianças necessitam da cidade; a cidade necessita das crianças. (TONUCCl, 2009, p. 147, tradução nossa).

O projeto da Cidade das Crianças defende a ideia de que as crianças nas ruas são capazes de torná-las mais seguras, favorecendo também para que esses locais sejam mais frequentados por outros atores que estavam reservados aos ambientes privados, como é o caso dos idosos, que, na possibilidade de auxiliarem na segurança infantil nos espaços públicos, visualizam aí uma oportunidade de voltar a frequentar a cidade. Com a ocupação das ruas e demais áreas públicas pelas crianças, com suas presenças e seus jogos, pode ocorrer a modificação do comportamento dos adultos, obrigando-os a respeitar mais o local em que vivem e onde irão viver seus filhos e netos. Dessa forma, sociedade passa a entender que a questão da infância é uma responsabilidade de todos e não apenas dos pais. 
Quando a cidade esquece as crianças, esquece de todos os seus cidadãos e esquece de si mesma; mas se recupera essa relação, se dar-Ihes tempo e espaço para o jogo, se concede-lhes a palavra, a escuta e leva em conta suas ideias, talvez poderá salvar-se. (TONUCCI, 2006, p. 67, tradução nossa).

Nessa perspectiva, o projeto da Cidade das Crianças propõe pensar sobre o espaço urbano a partir das necessidades infantis e não mais dos adultos, pois satisfazendo essas demandas, todos também serão atendidos (idosos, pessoas com necessidades especiais, deficientes e adultos). 0 projeto não prevê a criação de mais estruturas ou serviços especializados, mas sim a volta do atendimento às carências infantis, possibilitando sua autonomia e participação.

$\mathrm{Na}$ contramão do que vem acontecendo na atualidade, em que a cidade especializa-se, cada vez mais, em áreas destinadas às crianças - creches, escolas, parquinhos infantis, brinquedotecas - apartadas da experiência urbana como um todo e restringindo-Ihes o direito de desfrutar da cidade de maneira ampla, as diretrizes apresentadas pela Cidade das Crianças propõem pensar e projetar espaços múltiplos que possam ser utilizados por todas as idades, sem distinção de grupos específicos, onde as diferentes faixas etárias possam usufruir e encontrar-se em um mesmo local.

Segundo Tonucci (2009), a proposta da Cidade das Crianças em adotar a criança como parâmetro para projetar e administrar a cidade se move em duas direções:

1. permitir a participação das crianças no governo e nas políticas públicas;

2. recuperar a autonomia de movimento e deslocamento infantil na cidade.

Dentro do projeto da Cidade das Crianças, algumas iniciativas foram elaboradas para que as crianças assumissem sua autonomia e participação na medida da transformação urbana, tais como: projeto "Para a escola vamos sozinhos", "Conselho das crianças" e "Conselho dos alunos", dentre outros. Essas três propostas colocam os meninos e meninas como sujeitos do ambiente em que habitam e capazes de exercer a responsabilidade e a autonomia por aquilo que fazem e propõem. 
Para que as crianças sintam-se seguras nas cidades, podendo sociabilizar e viver experiências autônomas são necessárias mudanças em vários níveis, dentre eles:

- na relação entre automóveis e pedestres, sobretudo para aqueles mais vulneráveis;

- na compreensão da importância das crianças saírem sozinhas para se encontrar com seus pares;

- na criação de novos aliados às crianças nos espaços urbanos, tais como policiais, idosos, comerciantes e todos os cidadãos.

As propostas da Cidade das Crianças não veem os meninos e meninas como futuros cidadãos, mas busca reconhecer seus direitos e necessidades enquanto sujeitos no presente, propondo a participação na cidade a fim de transformá-la e tornála mais humana para todos que a habitam. Dessa forma, os Conselhos - das Crianças e dos Alunos - e os projetos criados para as crianças visam ouvi-las e colocá-las como parâmetros das mudanças urbanas.

Repensar a cidade a partir dos parâmetros infantis significa também incorporálos aos projetos e propostas dos espaços públicos e privados de usos coletivos, como é o caso de museus, hotéis, restaurantes e demais ambientes que, atualmente, privam suas manifestações e interações, quando não as impede de frequentar tais lugares. Refletir sobre essas propostas requer uma real transformação de postura política e social e uma incorporação das crianças no planejamento urbanístico da cidade como um todo. Mas será que, enquanto adultos, estamos dispostos de abrir mão de algumas exclusividades a fım de possibilitar a inclusão das crianças nas cidades?

Comparando-se os dois projetos apresentados, as propostas da Cidade Educadora não visam apenas as crianças, propõem-se pensar a cidade na construção de espaços educadores para todos, entendendo a educação não apenas como exclusividade de um período da vida, mas como presente em todas as fases. Porém, nos 
trazem inquietações sobre qual é o público efetivamente atendido por tais propostas, já que, como pôde ser observado no caso brasileiro, não atinge as camadas mais carentes. Além disso, também nos coloca para refletir sobre de que maneira podemos problematizar os aspectos negativos e de desigualdade urbana, para que a cidade possa ser realmente educadora e não caiamos no engano de considerar superficial e precocemente todos os espaços como potencialmente educadores.

Já as propostas da Cidade das Crianças é um projeto político que visa a mudança dos parâmetros da cidade, ou seja, nos convida a pensar sobre os espaços urbanos a partir da criança e não do homem adulto; não que esse não seja importante e será negado dentro dessa visão, mas ele também será favorecido a partir do atendimento às necessidades e às demandas infantis, pois atendidas essas carências, os demais cidadãos também serão contemplados. Da mesma maneira como no projeto da Cidade Educadora, a Cidade das Crianças também nos apresenta o desafio da implantação de suas propostas na realidade brasileira das grandes cidades e metrópoles, como é o caso de São Paulo, onde, muitas vezes, as relações entre as diferentes secretarias públicas municipais inviabilizam a realização de medidas e projetos interdisciplinares. Porém, o grande destaque desse projeto é colocar a criança como protagonista e agente dentro dos espaços urbanos.

Para ambas as propostas, contextualizando-as nos cenários e situações urbanas ocidentais atuais, cabe ainda refletirmos sobre quais escalas e proporções esses projetos podem adquirir, já que se desenvolvem na contramão das lógicas urbanas cada vez mais ligadas às posições capitalistas da globalização, do neoliberalismo e da sociedade do automóvel.

\subsubsection{Iniciativas em São Paulo}

Além dos dois exemplos apresentados, é importante destacar que, apesar da predominância nas políticas públicas de ações com pouca participação das crianças 
na construção dos espaços urbanos, existem outros movimentos e projetos no cenário mundial e brasileiro, que tomam como inspiração as propostas da Cidade Educadora e da Cidade das Crianças.

Em São Paulo, podemos apontar alguns projetos e experiências que se desenvolvem como possibilidades de trabalhar com as crianças no meio urbano, de modo a concebê-las como cidadãs de respeito, que merecem ser atendidas e escutadas em suas necessidades:

\section{- Bairro Educador Heliópolis, início nos anos 2000}

Principal objetivo: redesenhar e criar no território um espaço educativo, baseado na concepção de Educação Integral, associando equipamentos e serviços públicos, moradores, comunidade escolar e crianças, de modo a garantir mecanismos de participação na gestão e nas decisões a serem tomadas.

\section{- Projeto Criança Fala na Comunidade - Escuta Glicério, nos anos de 2015 e 2016}

Principal objetivo: escutar as crianças, de 3 a 11 anos, moradoras do Glicério, na expressão de suas opiniões sobre o bairro e o entorno onde moram, visando transformar, ocupar e ressignificar os espaços públicos cotidianos com a participação infantil e da comunidade.

\section{- Olhe o degrau- Jardim Ângela, nos anos de 2015 e 2016}

Principal objetivo: escutar os estudantes de uma escola estadual no Jardim Ângela, para requalificar, com a participação das crianças e da comunidade, a escadaria localizada em frente à escola, que era considerada um local degradado e violento.

\section{- Exploradores da Rua, início no ano de 2015}

Principal objetivo: promover caminhadas com as crianças possibilitando a descoberta, a exploração, a transformação e a apropriação do espaço urbano por elas, a fim de fomentar uma crescente autonomia e capacidade de participação infantil ativa na 
cidade.

- Caminho Escolar de Paraisópolis, nos anos de 2011 até 2013

Principal objetivo: incentivar a autonomia dos estudantes nos percursos casa-escola, garantindo o direito das crianças à cidade e a melhoria das condições de segurança, infraestrutura e convivência nos espaços públicos utilizados pela comunidade escolar durante os trajetos.

\section{- Carona a pé, início no ano de 2015}

Principal objetivo: melhorar a relação cidade-criança, possibilitando novas sociabilidades, autonomia e responsabilidades infantis através do deslocamento a pé e em grupos até a escola. Esses grupos são compostos por crianças moradoras de

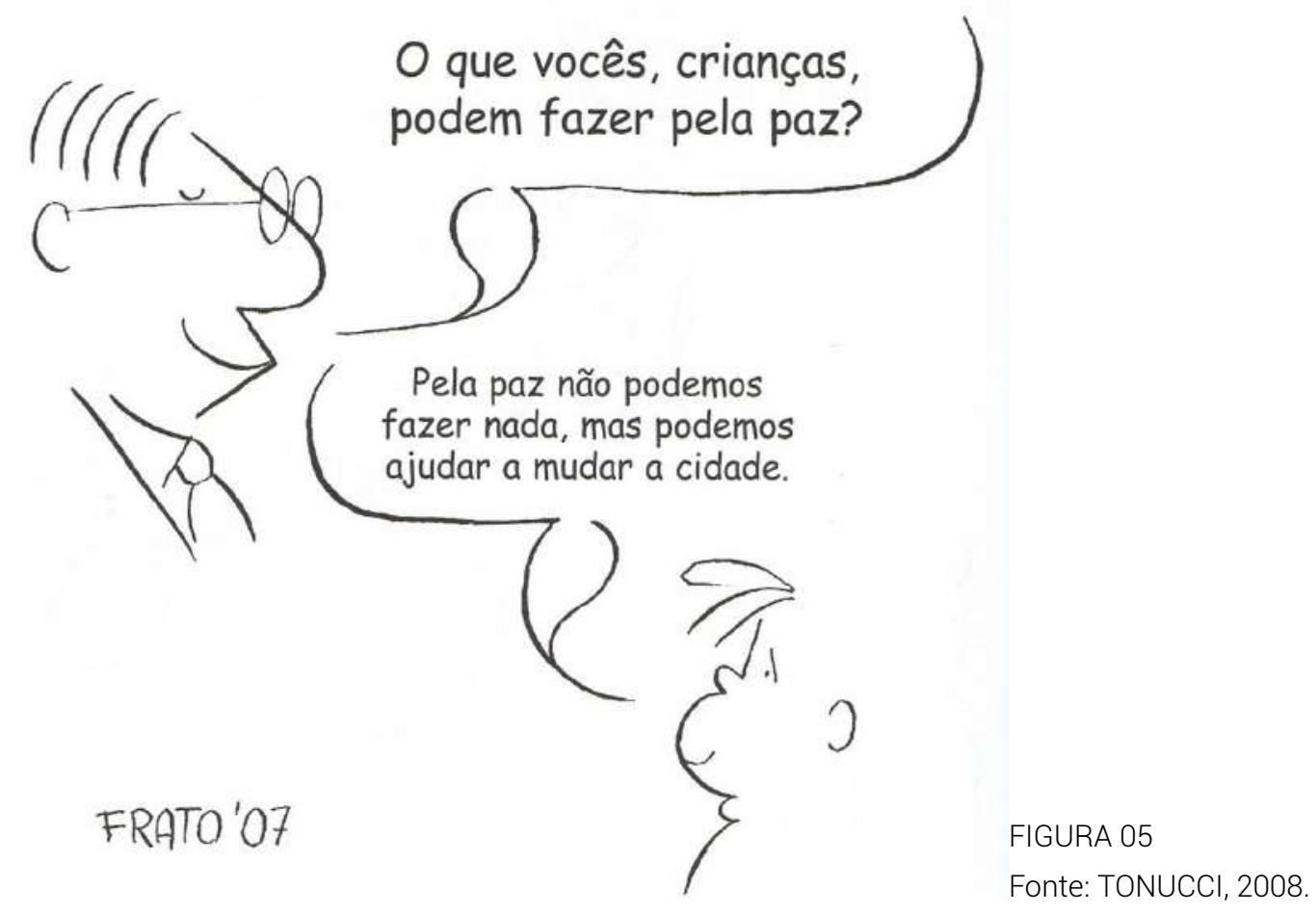


uma mesma área, que é acompanhado por três adultos, que se revezam diariamente, para a condução dos estudantes.

Além desses exemplos citados, existem outros projetos e iniciativas particulares ou coletivas que, apesar da pouca ou inexistente divulgação, também promovem a escuta, o protagonismo e a participação infantil nos espaços da cidade.

Essas experiências se mostram muito interessantes enquanto propostas que colocam as crianças como cidadãs e sujeitos de importância e respeito dentro do ambiente urbano. No entanto, por caracterizarem-se como iniciativas particulares e de organizações que não atingem a abrangência das políticas públicas, vale refletir sobre a possível fragilidade de manutenção e de continuidade de seus processos, buscandose evitar que se tornem apenas ações pontuais e eventuais dentro de uma dinâmica urbana complexa, como é o caso de São Paulo.

Porém, ao destacar tais intervenções, estamos refletindo também sobre as possibilidades delas serem partes de um percurso necessário a ser percorrido, a fim de denunciar e apontar para a necessidade de um olhar mais atento para as questões das infâncias nos espaços urbanos, tendo como finalidade a construção e a implantação de medidas e políticas públicas que passem a, efetivamente, considerar as crianças como agentes sociais.

Não é possível pensar na elaboração de uma política sólida para atender as demandas infantis se essa for planejada apenas dentro de intervenções pontuais ou de políticas partidárias, que deixam de ser realizadas com a mudança de gestão. É preciso planejar uma política de Estado que seja permanente e vertical, passando por departamentos, secretarias, órgãos, instituições públicas ou particulares e pela sociedade como um todo, a fim de constituir, a participação de todos esses agentes.

Na sequência, dentro dessa reflexão sobre a atuação infantil na discussão para a construção da cidade, apresentaremos a experiência realizada por essa pesquisa e seus sujeitos participantes. 


\section{CAPÍTULO 2}

\section{A CIDADE PERIFÉRICA E SUAS INFÂNCIAS: AS CRIANÇAS DO}

JARAGUÁ ENTRAM EM CENA

Eu só não queria significar.

Porque significar limita a imaginação.

Manoel de Barros $^{19}$

${ }^{19}$ BARROS, Manuel. Menino do mato. $1^{\text {a }}$ ed. Rio de Janeiro: Objetiva/ Alfaguara, 2015. 


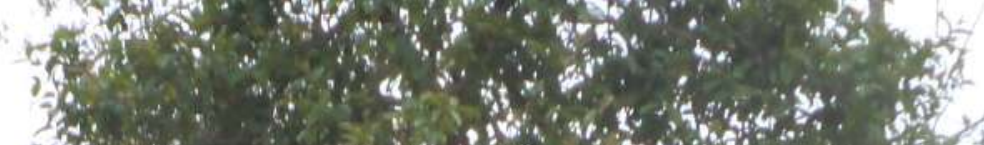

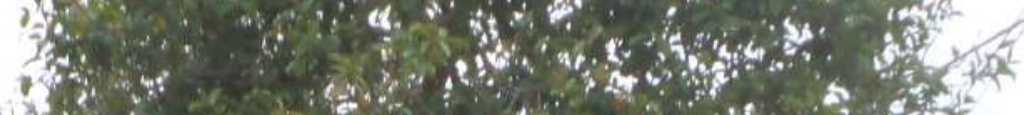

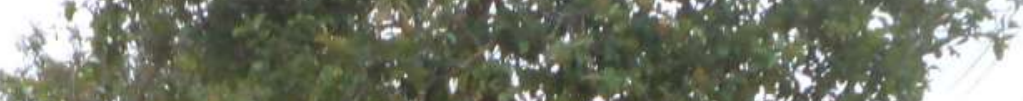
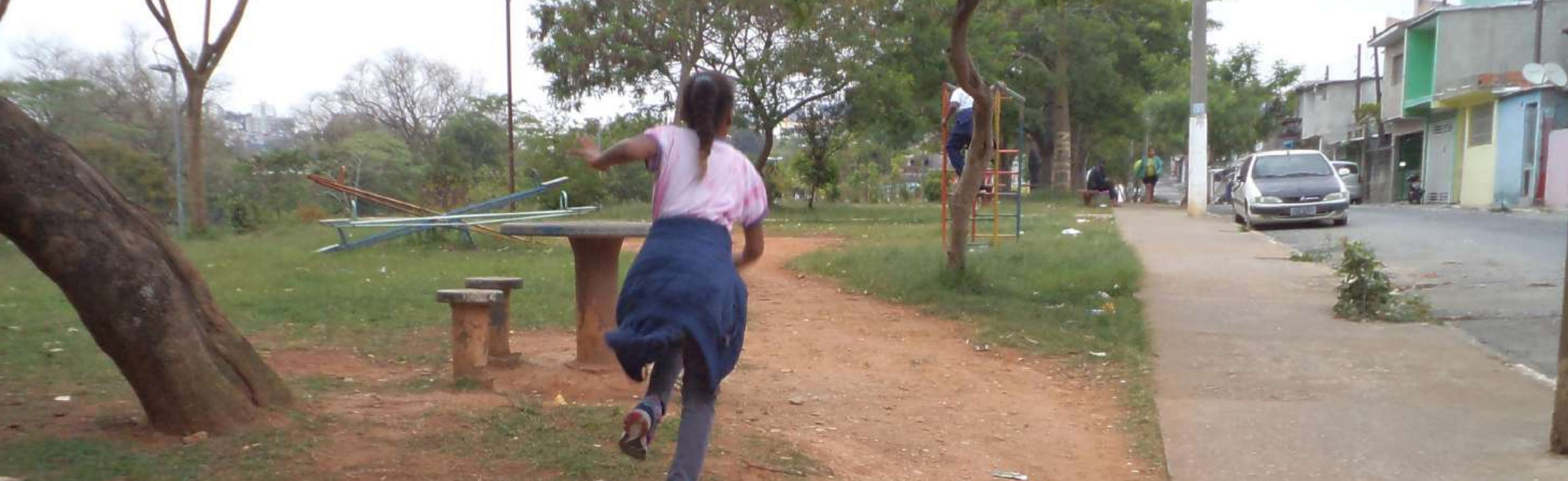

ne?
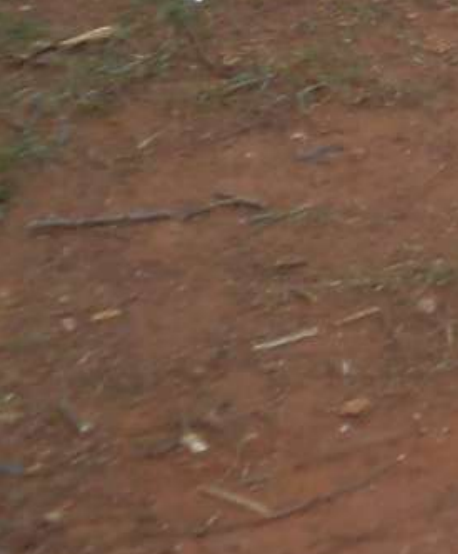

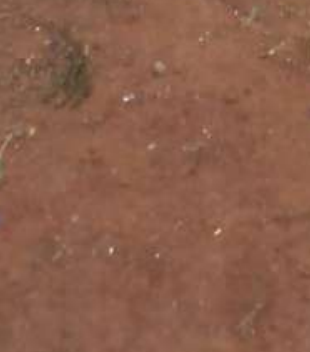


FIGURA 06 [verso]

Fotografia feita pelo grupo de Débora, Guilherme e Thainá durante visita ao entorno da escola. Máquina fotográfica digital, setembro de 2016.

Fonte: Arquivo pessoal, 2016. 
Antes que os sujeitos desse trabalho (as crianças participantes das oficinas realizadas nessa pesquisa) assumam, efetivamente, a cena, cabe aqui uma breve apresentação de como esse processo se desenvolveu, a fim de que, nos capítulos que se seguem, possamos entrar em contato com as leituras e reflexões infantis suscitadas durante o desenrolar desse estudo.

Adentrar o universo infantil tornou-se um grande desafio para uma arquiteta que não estava tão inserida em contextos pedagógicos. Porém, os encantamentos proporcionados por estas visões e as possibilidades de transformação da realidade que as crianças carregam, tornou-se um fator importante, fortalecendo, cada vez mais, o desenvolvimento da pesquisa.

Entendendo a arquitetura como um campo ligado às ciências humanas e, sobretudo, acreditando nos papéis de trocas e aprendizados entre as demais áreas de conhecimento e as pessoas - adultos e crianças - produtoras desses conhecimentos, a aproximação com a pedagogia e a sociologia da infância mostrou-se fundamental para compor a investigação que esse estudo propõe fazer.

A escolha em trabalhar com meninos e meninas dentro do universo escolar alunos do $2^{\circ}$ ano do ensino fundamental I da Escola Municipal de Ensino Fundamental (EMEF) Doutor José Kauffmann - deu-se pela facilidade em acompanhá-los em suas percepções, usos e propostas para os espaços urbanos. Somada a essas razões, a abertura proporcionada pela professora responsável pela turma também favoreceu a realização das oficinas, inclusive, auxiliando-as em determinados momentos. $\mathrm{Na}$ contramão de uma realidade educacional pública que, em muitis exemplos, conta com educadores insatisfeitos e desmotivados pelas condições oferecidas à prática pedagógica - baixas remunerações e limitações de materiais e suportes físicos -, tal professora demonstrou grande interesse em trabalhar o conhecimento dos alunos além das salas de aula, compreendendo que as oficinas também se caracterizavam como oportunidades de aprendizado e de desenvolvimento infantil.

O contato inicial com o grupo fez-se em uma atividade desenvolvida pela 
Secretaria Municipal de Desenvolvimento Urbano da Prefeitura de São Paulo (SMDUPMSP), no Parque Pinheirinho d'Água, em março de 2016, quando as crianças participavam de uma consultoria para a implantação do futuro edifício do Centro Educacional Unificado (CEU) Pinheirinho d'Água, que será localizado em trecho do atual Parque Linear do Fogo. Ambos os parques se localizam muito próximos à EMEF Doutor José Kauffmann, sendo, portanto, espaços bastante conhecidos e frequentados pela maioria das crianças participantes da pesquisa.

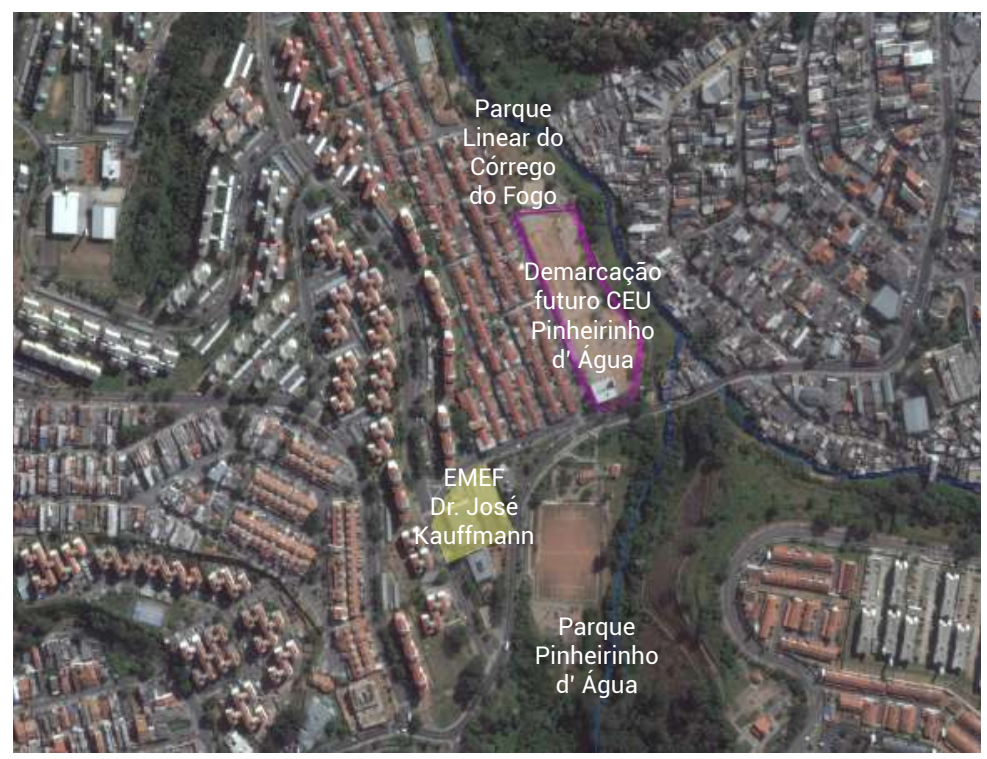

\section{FIGURA 07}

Localização da escola em seu entorno imediato. Notas sobre foto aérea.

Fonte: Google Earth, out. 2017.

Nas oficinas realizadas, que tiveram duração de três meses, participaram 27 crianças - 13 meninos e 14 meninas - entre 7 e 8 anos, moradoras, quase que em sua totalidade, das proximidades da escola localizada no Jardim Rincão, distrito do Jaraguá, região Noroeste do Município de São Paulo. Apenas um dos meninos participantes morava no bairro do Morro Doce, distrito Anhanguera, pertencente à prefeitura regional vizinha.

Faz-se necessário destacar aqui, que ao nos referirmos às crianças participantes da pesquisa, muitas vezes serão utilizados termos como 'crianças' ou 'meninos e 
20 ALDERSON, Priscilla. Children as Researchers. In: CHRISTENSEN, Pia; JAMES, Allison (Orgs.). Research with Children: perspectives and practices. London: Routledge, 2008. meninas' ou ainda 'sujeitos da pesquisa', não como forma de generalizações indevidas, mas como aproximação desses atores, sem tornar a leitura do texto demasiadamente cansativa.

Nessa perspectiva, as crianças não foram encaradas como objetos de estudo, mas como participantes da pesquisa, reconhecendo nelas seus conhecimentos, suas experiências e suas capacidades de decisão e proposições.

A participação das crianças em pesquisas pressupõe mudar a ênfase de métodos e tópicos. Reconhecer as crianças como copesquisadoras ao invés de apenas objetos de pesquisa envolve aceitar que as crianças podem 'falar' por si mesmas e relatar pontos de vista e experiências válidos. (ALDERSON, 2008, p. $278^{20}$ apud FARIAS; MULLER, 2017, p.264)

Do mesmo modo, vale apontar que apesar das atividades terem se desenvolvido dentro do ambiente escolar, mas sem o objetivo de serem escolarizantes e buscando diferenciar os papéis colocados pela sociedade entre as 'crianças' e os 'alunos', optou-se pela utilização do termo 'aluno' apenas quando esse estiver relacionado às atividades de cunho didático e pedagógico. Como esses objetivos não fazem parte das intenções da pesquisa, trabalhou-se aqui as manifestações infantis de maneira o mais livre possível de interferências, avaliações e julgamentos adultos, por esse motivo alguns textos presentes nos trabalhos não sofreram correções ortográficas, a fim de manter as ideias e manifestações infantis livres de constrangimentos.

Entretanto, mesmo que explicitamente a escola não apareça em seu aspecto avaliativo, o fato das oficinas e das produções infantis terem se desenvolvido dentro desse ambiente e durante os períodos das aulas, pode-se levantar a hipótese de que os pensamentos e as produções estiveram, ainda que parcialmente, influenciados por esse contexto. Pois, assim como apresenta Leite (2001, p.114): "escolarizamos nossas brincadeiras, nossas áreas de lazer, a literatura, a arte... o universo: tudo fica a serviço da relação ensino-aprendizagem." Nessa perspectiva, levantamos a questão: será que essas mesmas crianças, estando fora da escola, responderiam de outras maneiras as 
proposições apresentadas?

Contrária à ideia de que o termo infância traz em sua origem do latim - in = não e fans = fala, voz -, referindo-se ao indivíduo que não tem voz ou é incapaz de falar, esse trabalho aborda as crianças e suas produções como sujeitos ativos para pensar a cidade. Parte-se do princípio de que a infância é um momento importante durante a vida do ser humano, que merece ser tratada com atenção, respeito e valorização, refuta-se a

concepção de criança como fase, como adulto que-ainda-não-é. Portanto, debruçar-se sobre esta visão faseológica me parece contraditório com uma visão de criança enquanto sujeito social e histórico, contextualizado, produtor e crítico de cultura, com especificidades que a distinguem dos adultos. (LEITE, 2001, p.8)

0 trabalho concebe a criança como ator social e cultural, capaz de elaborar modos particulares de pensar, sentir, saber, interpretar e fazer (MARTINS FILHO; PRADO, 2011). É aqui explorado o papel do protagonismo infantil dentro da pesquisa, com enfoque nas leituras infantis dos espaços livres públicos da periferia de São Paulo e das relações que ali se estabelecem, permeadas por carências de todas as espécies - saúde, educação, moradias, saneamento, segurança, transportes, cultura, lazer e espaços públicos qualificados - que revestem as vivências cotidianas.

As crianças vistas e colocadas como sujeitos da pesquisa trazem elementos e informações diferentes daqueles fornecidos pelos adultos (DEMARTINI, 2011). Assim, não basta apenas consultar o adulto sobre o quê e como as crianças pensam, pois, essa visão apresenta-se limitada por um entendimento de mundo que não é condizente com a realidade infantil. 


\subsection{As oficinas}

As oficinas realizadas com as crianças partiram da intenção de exploração do universo infantil quanto aos conhecimentos e saberes adquiridos e construídos por elas em suas vivências e experiências nos espaços públicos cotidianos.

A escolha em trabalhar, inicialmente, as questões da cidade a partir dos elementos existentes nos bairros fez-se por acreditar ser esta a principal escala urbana vivenciada pelas crianças, onde se estabelecem seus contatos mais familiares e diários. A partir dessa leitura, foi possível ampliar as discussões, buscando uma aproximação com a cidade, trazendo novos temas a serem investigados pelas crianças. Nesse sentido, aproximamo-nos de Freire (1995), quando apresenta uma visão de mundo construída, primeiramente, na escala local:

Antes de tornar-me um cidadão do mundo, fui e sou um cidadão do Recife, a que cheguei a partir de meu quintal, no bairro da Casa Amarela. Quanto mais enraizado na minha localidade, tanto mais possibilidades tenho de me espraiar, me mundializar. Ninguém se torna local a partir do universal. 0 caminho existencial é inverso. (FREIRE, 1995, p.25)

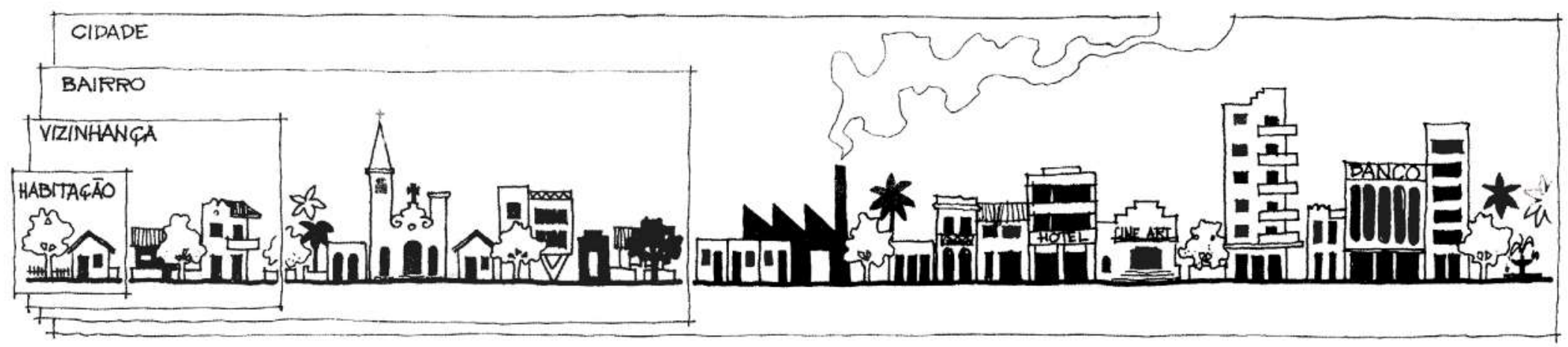

FIGURA 08

Escalas de usos e apropriações da cidade.

Fonte: SANTOS, 1988. 
Os primeiros contatos com os meninos e meninas foram de grande importância para o prosseguimento e a adaptação dos demais encontros, apontando para a necessidade da adequação de algumas propostas e de um menor controle das manifestações e expressões infantis, buscando-se adentrar e respeitar seus papéis na leitura do território e na construção de seus saberes sobre a cidade, especificamente em seus espaços livres públicos.

Para o desenvolvimento das oficinas, adotou-se uma postura que preconizou a mínima intervenção dos adultos sobre as respostas dadas pelas crianças diante das propostas apresentadas. Da mesma forma, os espaços livres públicos deixaram de ser colocados em evidência, verificando-se o seu aparecimento (ou não) nas manifestações infantis.

Pode-se dizer que o desenvolvimento das oficinas trouxe grande aprendizado e oportunidades em trabalhar a pesquisa-ação ${ }^{21}$ de acordo com as respostas dadas pelas crianças. Havia, inicialmente, uma preocupação mais limitada com os resultados que seriam obtidos e os caminhos que seriam percorridos, porém, com o decorrer dos encontros, priorizou-se, cada vez mais, a parceria entre a pesquisadora e as crianças. Os resultados e as oficinas seguintes começaram a depender dessa ação conjunta, não sendo possível um controle total do processo, uma vez que as crianças, com suas colocações e intervenções, também estavam ajudando a rever e a construir as propostas das atividades seguintes.

[...] a pesquisa-ação é do tipo de pesquisa social com base empírica que é concebida e realizada em estreita associação com uma ação ou com uma resolução de um problema coletivo e no qual os pesquisadores e os participantes representativos da situação ou do problema estão envolvidos de modo cooperativo ou participativo [...], a participação das pessoas implicadas nos problemas investigados é absolutamente necessária. (THIOLLENT, 2008, p. 16-17).

Dessa maneira, as oficinas passaram por reformulações e adaptações durante todo o processo, se adequando ao calendário escolar e ao atendimento dos objetivos que se construíam em cada atividade. Ao todo foram realizadas dez oficinas com as
${ }^{21}$ A pesquisa-ação, tal como proposta por Michel Thiollent, preconiza a parceria do pesquisador com o 'objeto de estudo', sendo que os resultados dependem dessa ação conjunta, não existindo um controle total do processo, uma vez que este contempla diversos atores sociais, na dinâmica do tempo. 
crianças e duas reuniões com seus pais, abordando diferentes tipos de atividades com a temática da cidade, buscando-se conhecer como os espaços livres públicos apareciam nas manifestações e se eles realmente tornavam-se importantes ao falar do meio urbano.

As oficinas foram divididas em três etapas de abordagem:

1. Investigação e exploração - com o desenvolvimento de 5 oficinas e 7 atividades, os meninos e meninas refletiram sobre suas vivências cotidianas na cidade. As atividades trabalharam com desenhos, foto aérea, mapa e registros fotográficos.

Ao enfatizar o viés da investigação, as propostas realizadas nessa etapa buscaram o conhecimento de mundo das crianças e as interpretações urbanas por elas desenvolvidas. Essa postura colocou-as como sujeitos sociais, produtoras de cultura que se formam em relação e na interpretação do mundo, produzindo conhecimento a partir dessas experiências e vivências em campo. Nessa perspectiva, as crianças são vistas também como pesquisadoras, pois, através de suas investigações no mundo, elas constroem-se e desenvolvem-se.

Respeitar a leitura de mundo das crianças é colocar-se em uma posição democrática, de escuta e de atenção às visões, experiências e saberes constituídos nos espaços urbanos. "A leitura de mundo revela, evidentemente, a inteligência do mundo que vem cultural e socialmente se constituindo. Revela também o trabalho individual de cada sujeito no próprio processo de assimilação da inteligência do mundo." (FREIRE, 2016, p.121)

2. Experimentação - com o desenvolvimento de 2 oficinas e 3 atividades, as crianças, por meio da visualização de imagens e da vivência em um espaço público - o Jardim Botânico de São Paulo -, até aquele momento, desconhecido, ampliaram o repertório e a vivência de possíveis usos na cidade, vislumbrando possibilidades de mudanças nos espaços cotidianos.

Ao entrar em contato com experiências inéditas, trocando conhecimento 
entre pesquisadora e meninos e meninas, essa etapa proporcionou processos de aprendizagens a partir do entendimento de que somos (adultos e crianças) sujeitos inacabados, que se formam e transformam a cada nova experiência no mundo.

Para Paulo Freire (2016), compreender-se como sujeito inacabado nos coloca e coloca os demais, nesse caso, as crianças, em posição de descoberta e de busca. Nesse sentido,

[...] estar no mundo necessariamente significa estar com o mundo e com os outros. Estar no mundo sem fazer história, sem por ela ser feito, sem fazer cultura, sem 'tratar' sua própria presença no mundo, sem sonhar, sem cantar, sem musicar, sem pintar, sem cuidar da terra, das águas, sem usar as mãos, sem esculpir, sem filosofar, sem pontos de vista sobre o mundo, sem fazer ciência, ou tecnologia, sem assombro em face do mistério, sem aprender, sem ensinar, sem ideias de formação, sem politizar não é possível.

É na inconclusão do ser, que se sabe como tal, que se funda a educação como processo permanente. (FREIRE, 2016, p.57)

3. Desejos e projetos - com o desenvolvimento de 4 oficinas e 3 atividades, após as reflexões e as vivências possibilitadas anteriormente, as crianças projetaram, tal qual arquitetos, por meio de desenhos e maquetes, desejos de transformações e pedidos de mudanças para a cidade.

O intuito dessas atividades foi, através da concepção das crianças como sujeitos capazes e responsáveis pela transformação urbana, permitir que elas assumissem os papéis de participação e de direitos, que lhes são concedidos legalmente.

Segundo Tonucci (2005, p.188),

Dar a cidade às crianças, e não somente serviços, assistência, controles, pode ser um bom investimento: elas devolverão uma cidade melhor. Melhor porque se o envolvimento for real e não fictício, as crianças procurarão tornar a cidade adequada a suas necessidades; para fazer isso, serão obrigadas a torná-la melhor. Precisarão torná-la propriedade de todos, a fim de que sejam delas também. 


\section{OFICINA 01}

\section{ETAPA: INVESTIGAÇÃO-EXPLORAÇÃO}

PROGRAMAÇÃO: Apresentação + conversa sobre as cidades e suas representações (fotos, mapas, fotos aéreas, desenhos).

Produção de desenhos registrando o percurso de casa até a escola e as atividades realizadas no final de semana (desenhos produzidos em sala de aula, sem a presença da pesquisadora).

OBJETIVOS: Trocar experiências, entre pesquisadora e crianças, sobre a temática das cidades de uma maneira ampla e visualizar formas de representações dos espaços urbanos.

Através dos desenhos, refletir sobre a composição dos espaços cotidianos, vivenciados pelas crianças e seus possíveis usos em atividades aos finais de semanas.

\section{FIGURA 09 [esquerda]}

Foto aérea dos bairros City Jaraguá, Jardim Rincão, Parque Panamericano e Parque Nações Unidas, no Jaraguá.

Fonte: Google Earth, ago. 2016.

FIGURA 10 [superior direita]

Mapa Turístico do Rio de Janeiro. Fonte: Rio Map 360 2016

FIGURA 11 [inferior direita]

llustrações da cidade de Paris. Fonte: CASES, Zoé de Las. Segredos de Paris- livro de colorir \& passeios antiestresse. Rio de Janeiro: Sextante, 2015.
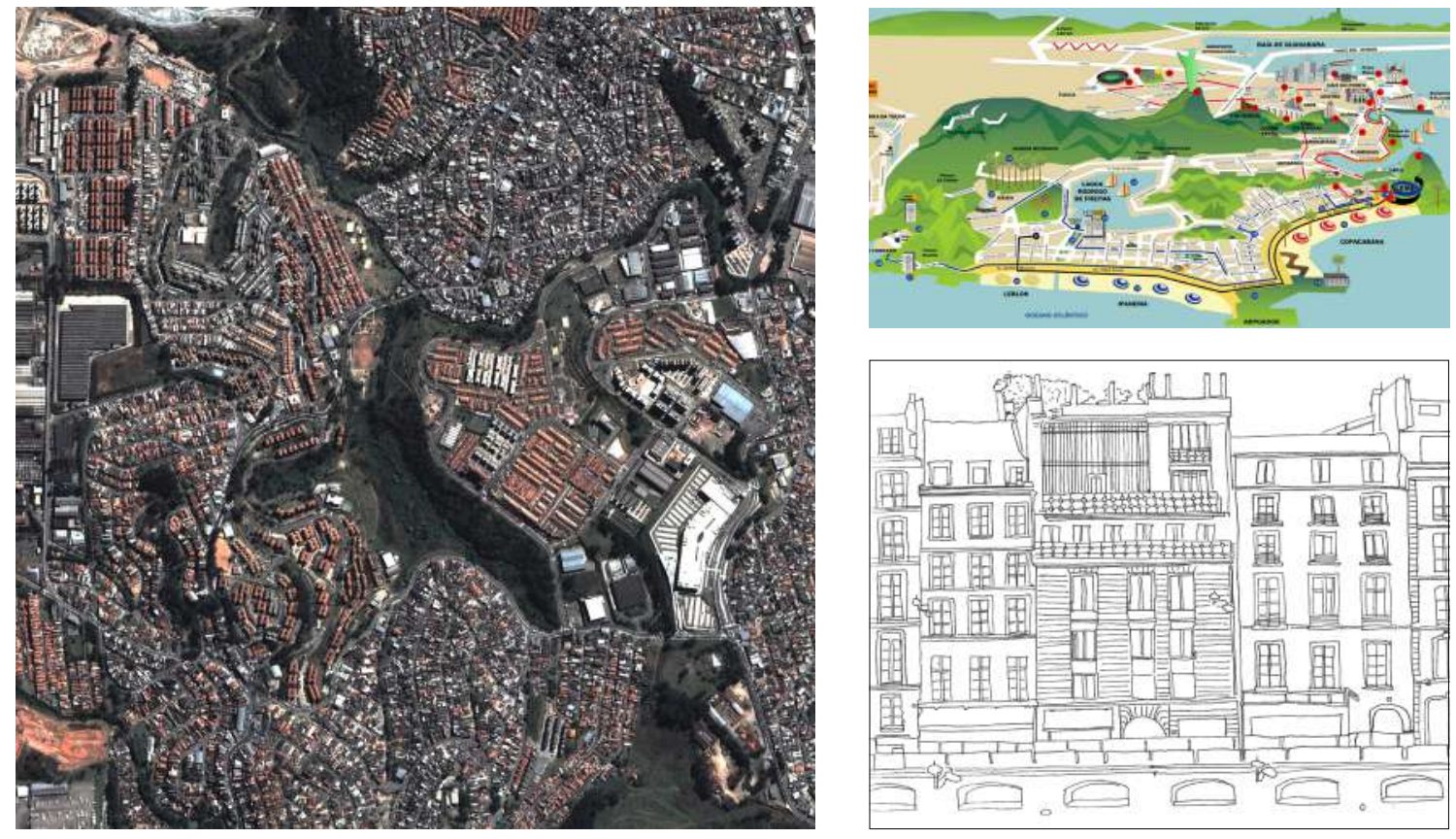


\section{OFICINA 02}

\section{ETAPA: INVESTIGAÇÃO-EXPLORAÇÃO}

PROGRAMAÇÃO: Trabalho em cima do mapa da cidade de São Paulo: lista de equipamentos + apresentação de lugares e pontos turísticos na cidade com localização sobre o mapa.

OBJETIVOS: Compartilhar os conhecimentos da cidade de São Paulo: as crianças apontaram lugares e elementos conhecidos por elas e a pesquisadora apresentou uma seleção de equipamentos existentes na cidade - Parque Pinheirinho d'Água, Parque Villa Lobos, Parque Ibirapuera, Instituto Butantan, Aeroporto de Congonhas, Estádio do São Paulo/ Morumbi, Estádio do Palmeiras, Estádio Municipal do Pacaembu, Sambódromo, Estação da Luz, Pinacoteca, Museu Catavento Cultural, Catedral da Sé, Teatro Municipal, Pateo do Collegio, Prédio do Banespa, Museu Paulista/ Ipiranga, Aquário de São Paulo, Jardim Botânico, Jardim Zoológico e Estádio do Corinthians - muitos deles desconhecidos pelas crianças.

\begin{tabular}{|c|c|c|}
\hline $\begin{array}{l}\text { - MORROS } \\
\text { - PONTE } \\
\text { - PARQUES } \\
\text { - TREM } \\
\text { - ZOOLÓGICO } \\
\text { - SHOPPING } \\
\text { - MC DONAID'S } \\
\text { - RUAS / CASAS } \\
\text { - ÁRVORES } \\
\text { - LOJAS } \\
\text { - ESCOLA } \\
\text { - HABIBS } \\
\text { - CONDOMINIO }\end{array}$ & $\begin{array}{l}\text { - RIO/PATOS } \\
\text { - SUJEIRA } \\
\text { - PRE'DIOS } \\
\text { RICOS COM } \\
\text { PISCINA } \\
\text { - PINHEIRINHO } \\
\text { D'ÁGUA } \\
\text { - POSTO DE } \\
\text { GASOLINA } \\
\text { - CEMITERIO } \\
\text { - ESTACÁO } \\
\text { DE TREM } \\
\text { - CARROS } \\
\text { - ÖNIBUS }\end{array}$ & $\begin{array}{l}\text { - GALINHAS } \\
\text { - DELEGACIA } \\
\text { - CACHORROS } \\
\text { - SUPERMERCANO } \\
\text { - PRACA DO } \\
\text { SAMBA } \\
\text { - PARQUE } \\
\text { ANHANGUERA } \\
\text { - SBT } \\
\text { - REPRESA } \\
\text { - CARTAZ } \\
\text { - PARQUINHO } \\
\text { COM BRINQUEDOS } \\
\text { QUEBRADOS } \\
\text { - RESTAURANIES }\end{array}$ \\
\hline
\end{tabular}

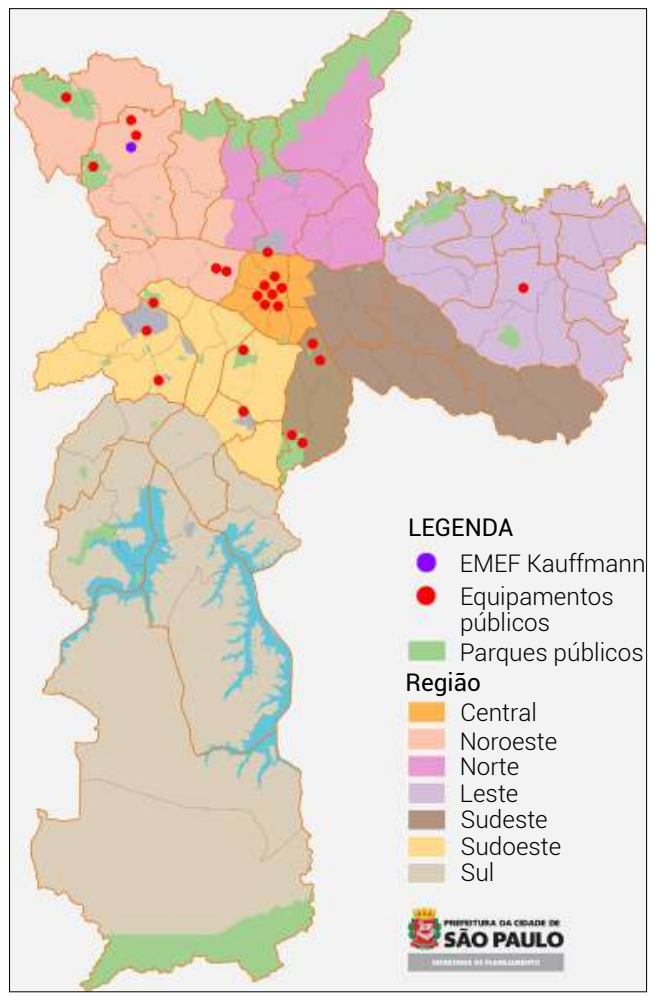

FIGURA 12 [esquerda]

Lista de elementos existentes na cidade de São Paulo, produzida com o conhecimento das crianças.

Fonte: arquivo pessoal, 2016.

\section{FIGURA 13 [direita]}

Localização de equipamentos públicos sobre Mapa Oficial do Município de São Paulo.

Fonte: Prefeitura Municipal de São Paulo 


\section{OFICINA 03}

\section{ETAPA: INVESTIGAÇÃO-EXPLORAÇÃO}

PROGRAMAÇÃO: Visita de campo no entorno da escola: Explorar, observar, vivenciar e registrar o bairro através de fotografias e desenhos.

OBJETIVOS: Conhecer os olhares e afetos das crianças sobre os bairros onde moram e vivenciam suas atividades cotidianas.

FIGURA 14 [esquerda]

Percurso realizado pelas crianças durante a Oficina 03. Notas sobre foto aérea.

Fonte: Google Earth, ago. 2016

FIGURA 15 [superior direita]

Crianças durante a visita ao entorno da escola.

Fonte: Leandro Fontana, 2016

FIGURA 16 [inferior direita]

Crianças durante a visita ao entorno da escola.

Fonte: Vera Valgas, 2016.

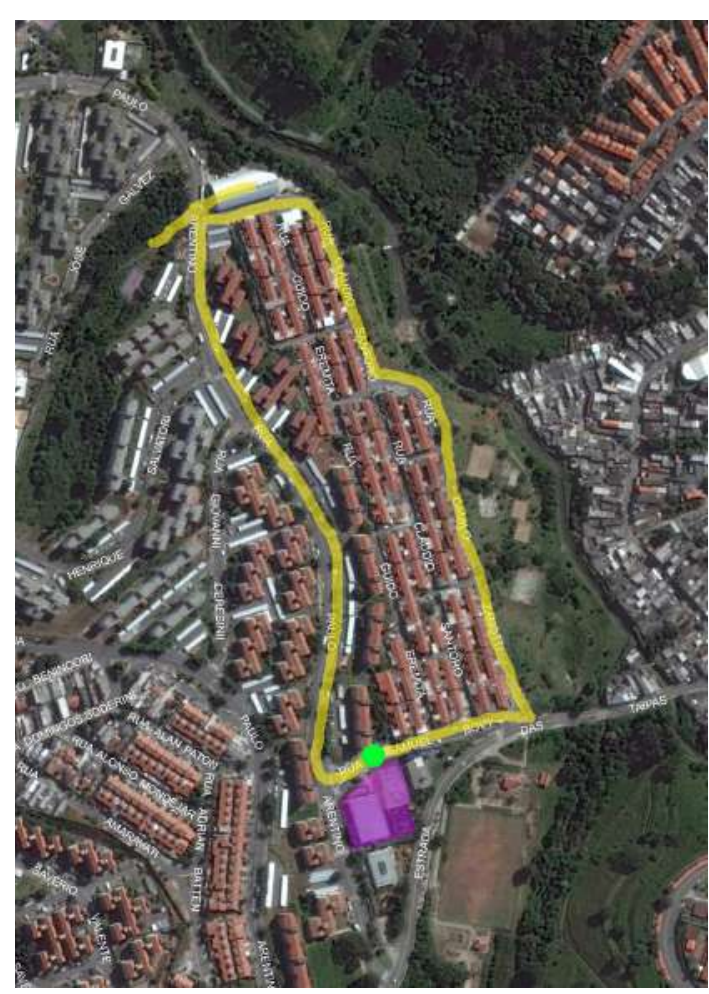

LEGENDA

EMEF Kauffmann

Ponto de partida e chegada

Percurso realizado
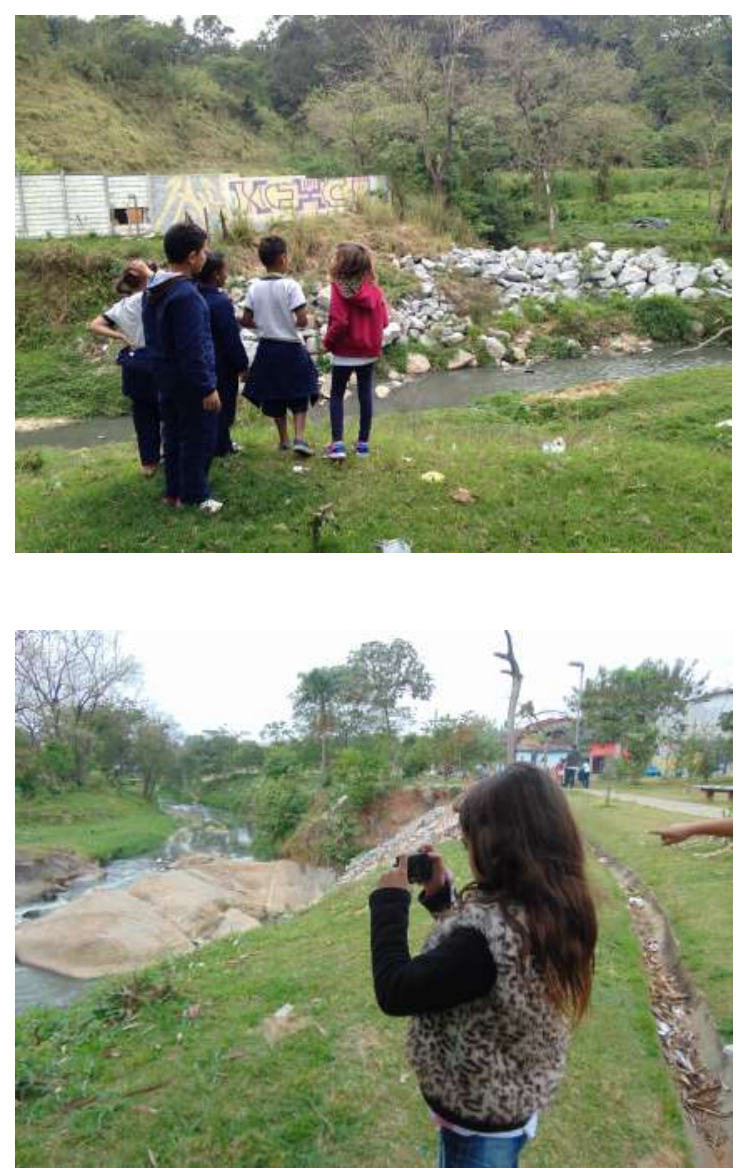


\section{OFICINA 04}

\section{ETAPA: INVESTIGAÇÃO-EXPLORAÇÃO}

PROGRAMAÇÃO: Leitura e reconhecimento do território cotidiano sobre foto aérea do entorno da escola: localização das casas das crianças e equipamentos do bairro.

OBJETIVOS: Investigar e se localizar no território através de um instrumento bastante empregado no campo da arquitetura e do urbanismo - foto aérea -, mas ainda pouco utilizado entre as crianças e os educadores.

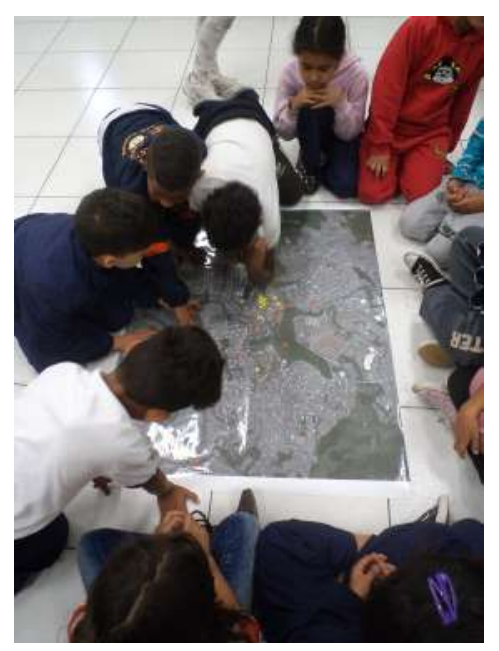

LEGENDA

EMEF Kauffmann

Equipamentos do

bairro

Casas das crianças

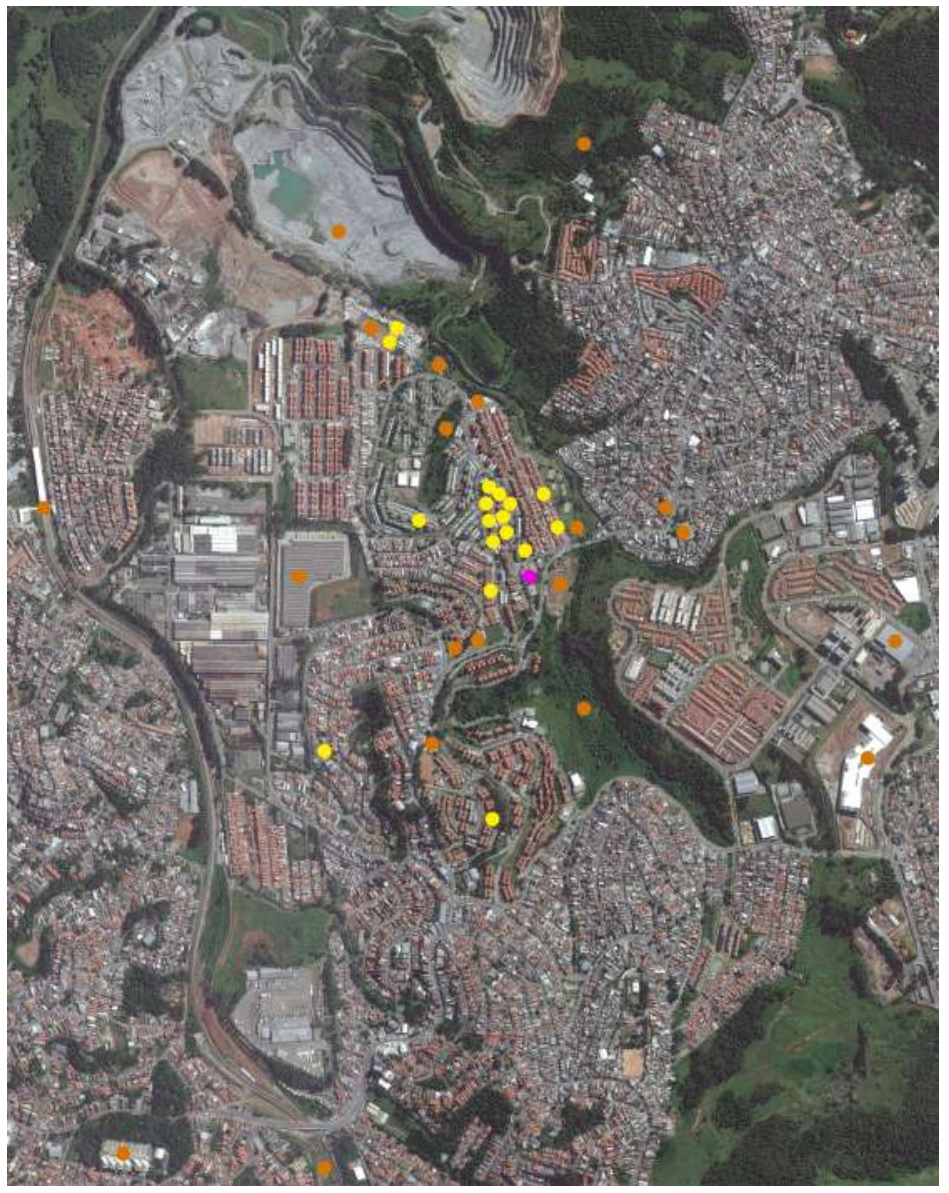

FIGURA 17 [esquerda]

Crianças em processo investigativo do bairro sobre foto aérea.

Fonte: Arquivo pessoal, 2016

\section{FIGURA 18 [direita]}

Localização das casas das crianças e dos equipamentos do bairro. Etiquetas coloridas sobre foto aérea.

Fonte: Google Earth, ago. 2016. 
FIGURAS 19 e 20 [superior esquerda e direita]

Crianças durante o processo de elaboração dos desenhos em resposta às temáticas solicitadas.

Fonte: Arquivo pessoal, 2016.

\section{FIGURA 21 [inferior esquerda]}

Desenho retratando a brincadeira preferida de um dos meninos participantes das oficinas (esconde-esconde).

Fonte: Arquivo pessoal, 2016.

\section{FIGURA 22 [inferior direita]}

Desenho retratando o que uma das meninas gostaria que tivesse no bairro onde mora (zoológico).

Fonte: Arquivo pessoal, 2016.

\section{OFICINA 05}

\section{ETAPA: INVESTIGAÇÃO-EXPLORAÇÃO + DESEJOS E PROJETOS}

PROGRAMAÇÃO: Construção de desenhos retratando as brincadeiras preferidas das crianças e o que elas gostariam que tivesse no bairro onde moram.

OBJETIVOS: Conhecer, através dos desenhos e das falas, a representação das crianças sobre os espaços urbanos e como os espaços livres públicos aparecem nas brincadeiras e nos desejos de transformação do bairro. Valorizar as crianças enquanto sujeitos capazes de expressar seus projetos por melhorias na cidade.
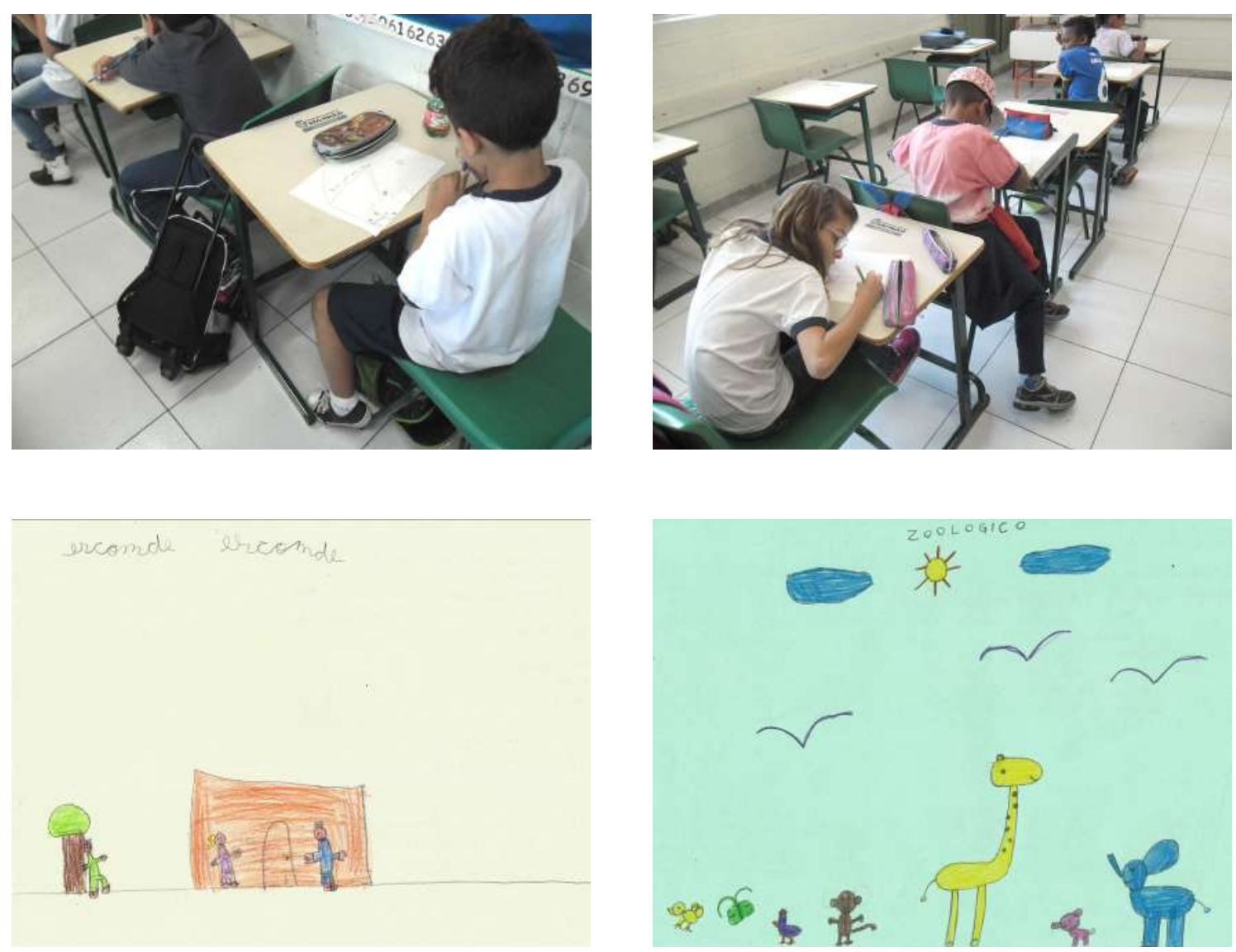


\section{OFICINA 06}

\section{ETAPA: EXPERIMENTAÇÃO}

PROGRAMAÇÃO: Apresentação de imagens com atividades e usos diversos nos espaços livres públicos urbanos + conversa sobre o quê as crianças fazem e o quê podem fazer nesses locais.

OBJETIVOS: Compartilhar e apresentar possibilidades de usos nos espaços públicos, ampliando o repertório de atividades potenciais nesses locais.
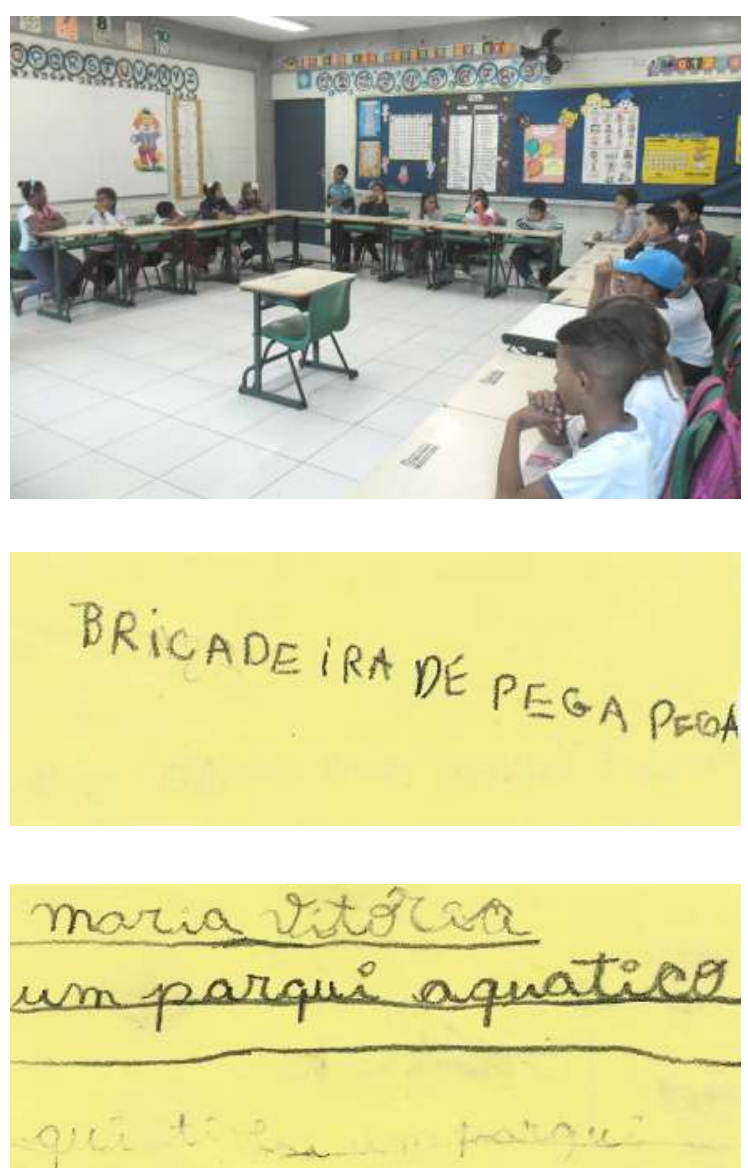
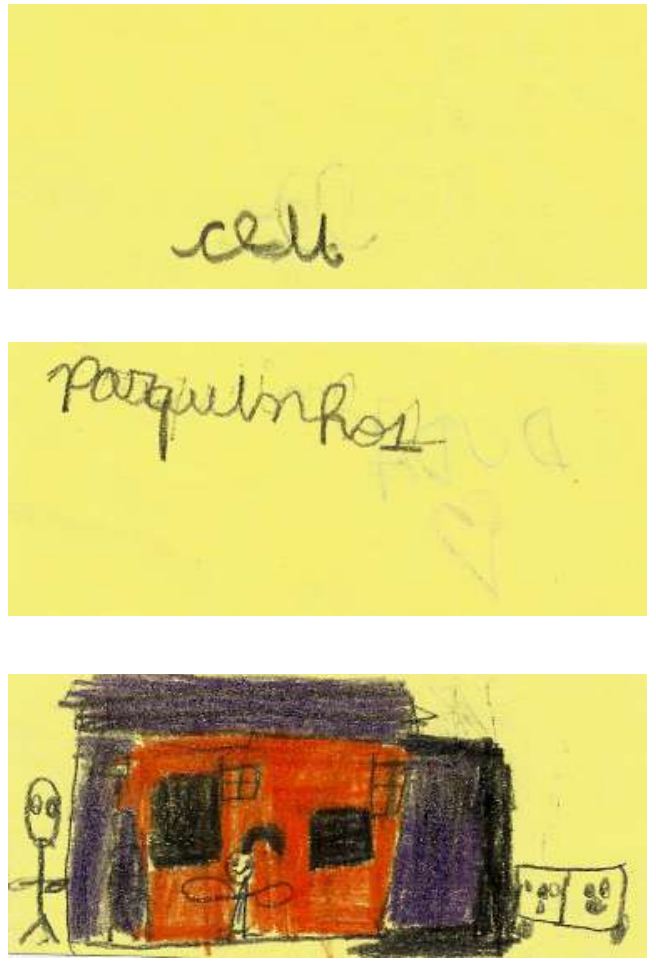

FIGURA 23 [superior esquerda]

Crianças durante conversa sobre as possibilidades de usos nos espaços públicos.

Fonte: Arquivo pessoal, 2016.

\section{FIGURAS 24, 25, 26, 27 e 28}

Indicação das crianças de possibilidades de usos nos espaços urbanos.

Fonte: Arquivo pessoal, 2016. 


\section{OFICINA 07}

\section{ETAPA: EXPERIMENTAÇÃO}

PROGRAMAÇÃO: Visita ao Jardim Botânico (natureza na cidade).

OBJETIVOS: Pré-visita: conhecer o imaginário das crianças sobre o Jardim Botânico;

Durante a visita: explorar, perceber, vivenciar e criar apropriações espontâneas em um espaço livre não conhecido pelas crianças;

Pós-visita: refletir como essa experiência pode ser trabalhada pela criança em sua formação no mundo (aprendizado na cidade).
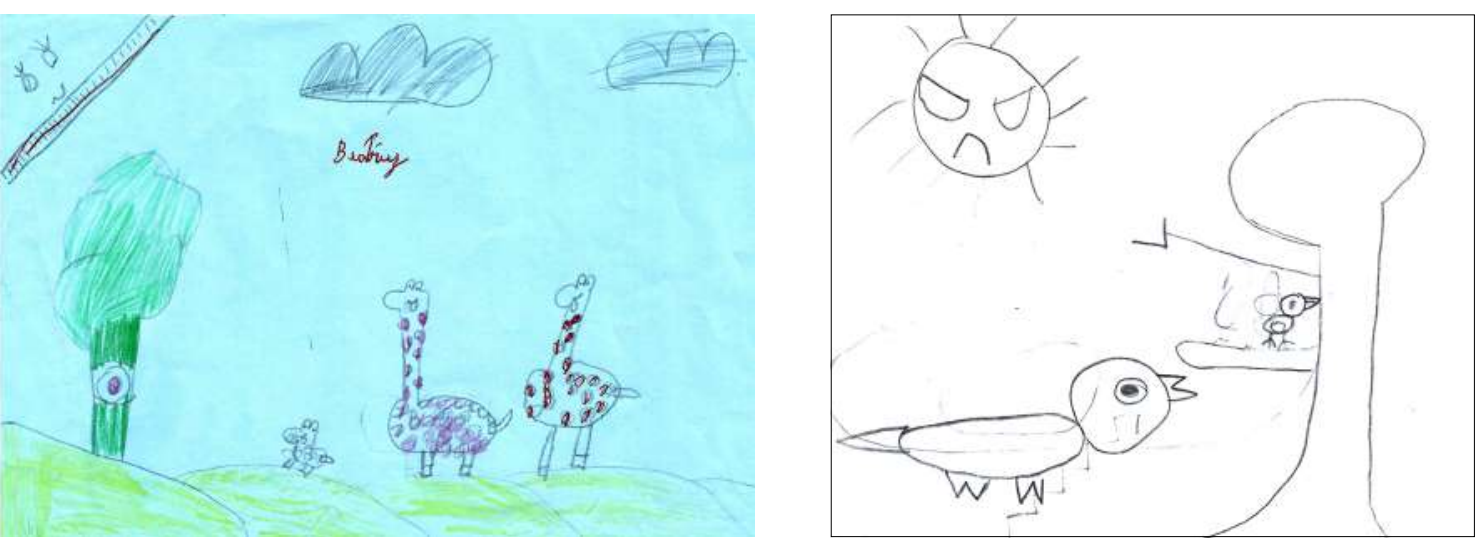

Desenho elaborado representando o imaginário do Jardim Botânico, antes da visita.

Fonte: Arquivo pessoal, 2016

FIGURA 30 [inferior esquerda]

Crianças durante a visita ao Jardim Botânico.

Fonte: Arquivo pessoal, 2016

\section{FIGURA 31 e 32 [direita]}

Desenhos retratando o que foi observado no Jardim Botânico. Fonte: Arquivo pessoal, 2016.
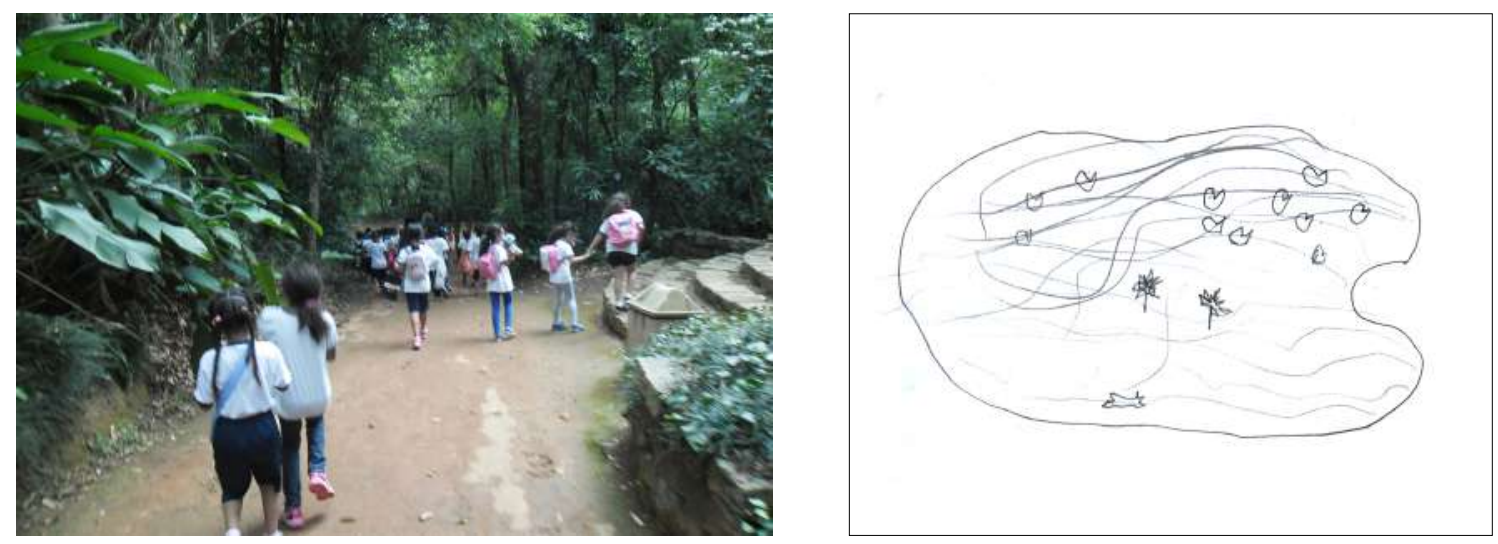


\section{OFICINA 08}

\section{ETAPA: DESEJOS E PROJETOS}

PROGRAMAÇÃO: Um dia de arquitetos: produção de maquetes com projetos que as crianças gostariam de construir na cidade

OBJETIVOS: Trabalhar a ideia da criança como um sujeito de direitos e desejos para a cidade. Refletir, através das produções realizadas, sobre a visão, a atuação e a participação infantil na cidade e na sociedade.
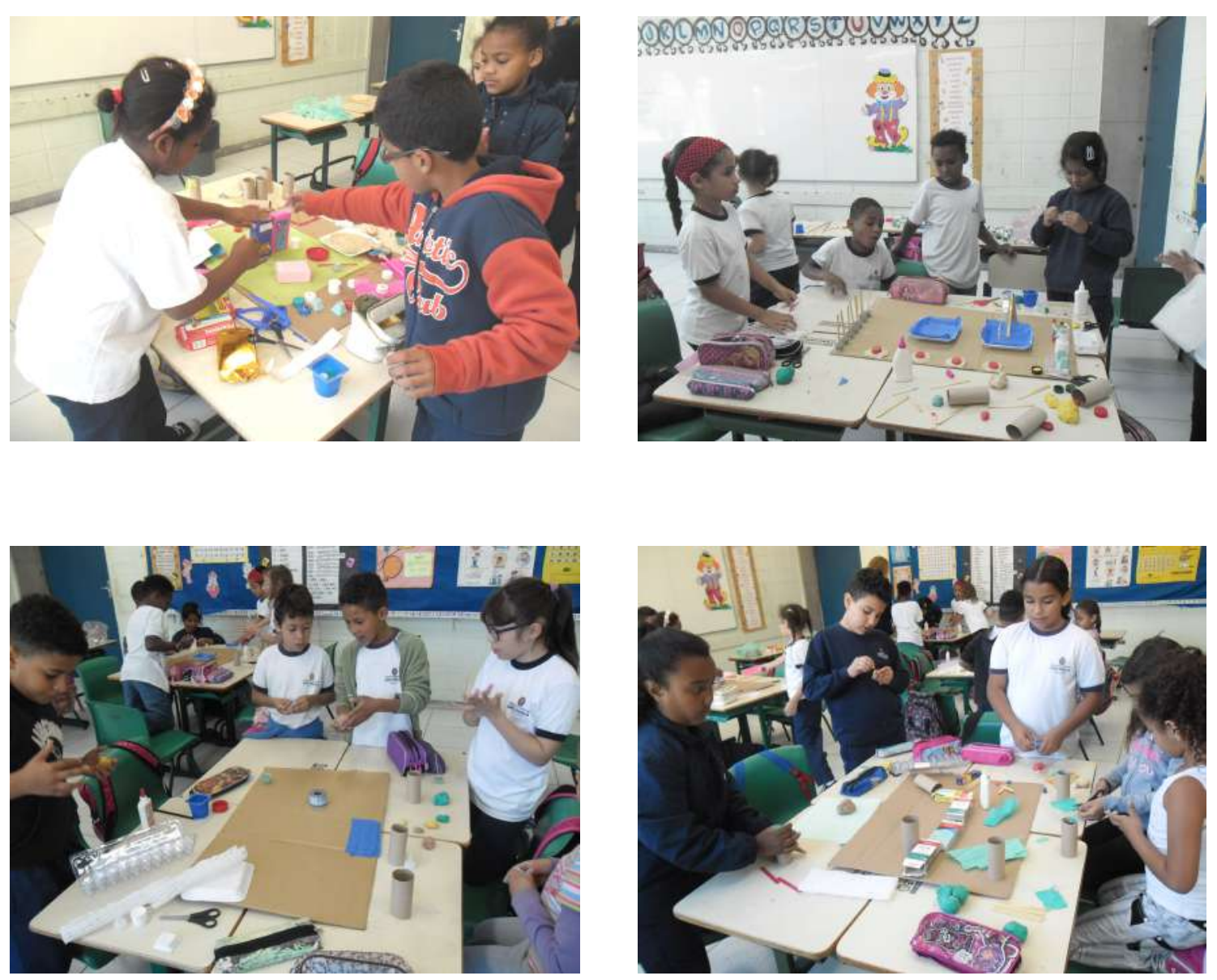

FIGURA 33, 34, 35 e 36

Crianças separadas em grupos durante o processo de elaboração das maquetes para representar aquilo que gostariam de construir na cidade.

Fonte: Arquivo pessoal, 2016 


\section{OFICINA 09}

\section{ETAPA: DESEJOS E PROJETOS}

PROGRAMAÇÃO: Finalização das maquetes + apresentação.

OBJETIVOS: Compartilhar os projetos com as demais crianças e com a pesquisadora;

Conhecer o processo de elaboração das propostas realizadas pelas crianças, nas quais elas identificaram demandas e desejos - pessoais ou coletivos - e desenvolveram um projeto para a melhora da cidade.

FIGURA 37 [superior esquerda]

Maquete elaborada com o projeto de um parque aquático.

Fonte: Arquivo pessoal, 2016

\section{FIGURA 38 [superior direita]}

Maquete elaborada com o projeto de um shopping center.

Fonte: Arquivo pessoal, 2016.

\section{FIGURA 39 [inferior esquerda]}

Maquete elaborada com o projeto de um condomínio habitacional com equipamentos.

Fonte: Arquivo pessoal, 2016.

\section{FIGURA 40 [inferior direita]}

Maquete elaborada com o projeto de uma praia.

Fonte: Arquivo pessoal, 2016.
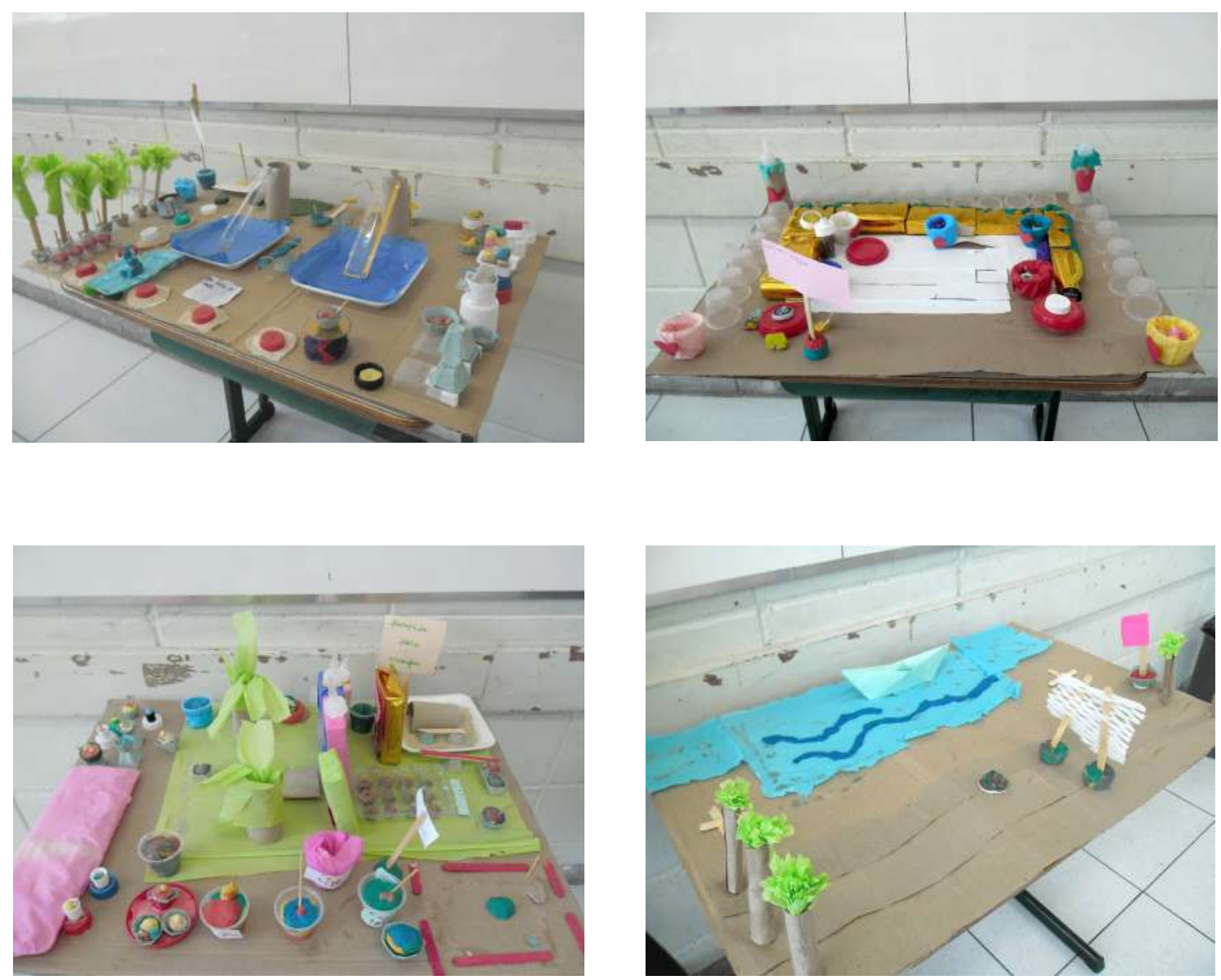


\section{OFICINA 10}

\section{ETAPA: DESEJOS E PROJETOS}

PROGRAMAÇÃO: Entrega dos livrinhos ${ }^{22}$ com a produção de cada criança + Bexigas com pedidos ao prefeito + Avaliação das oficinas pelas crianças

OBJETIVOS: Realizar a devolutiva das oficinas para as crianças, entendendo-as como agentes e pesquisadoras dentro de cada tema abordado e, portanto, com direito de receber os registros das atividades por elas realizadas;

Trabalhar a ideia da criança como sujeito de direito, capaz de solicitar à administração pública melhorias urbanas;

Ouvir a opinião e a avaliação das crianças sobre as atividades realizadas, a fım de refletir sobre a elaboração de formas adequadas para trabalhar com as crianças nos projetos arquitetônicos e urbanísticos, a partir daquilo que elas apontaram como eficientes e importante no processo e nos resultados.

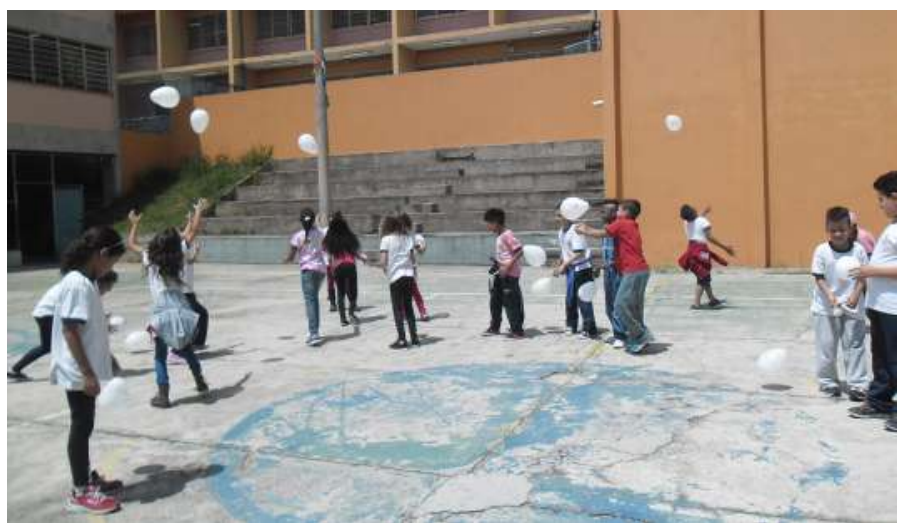

FIGURA 41 [acima]

Crianças soltando as bexigas com pedidos para serem conduzidas, simbolicamente, pelo vento até chegar ao prefeito.

Fonte: Arquivo pessoal, 2016.

FIGURA 42 e 43 [ao lado]

Livrinhos entregues às crianças com suas produções. Fonte: Arquivo pessoal, 2016.
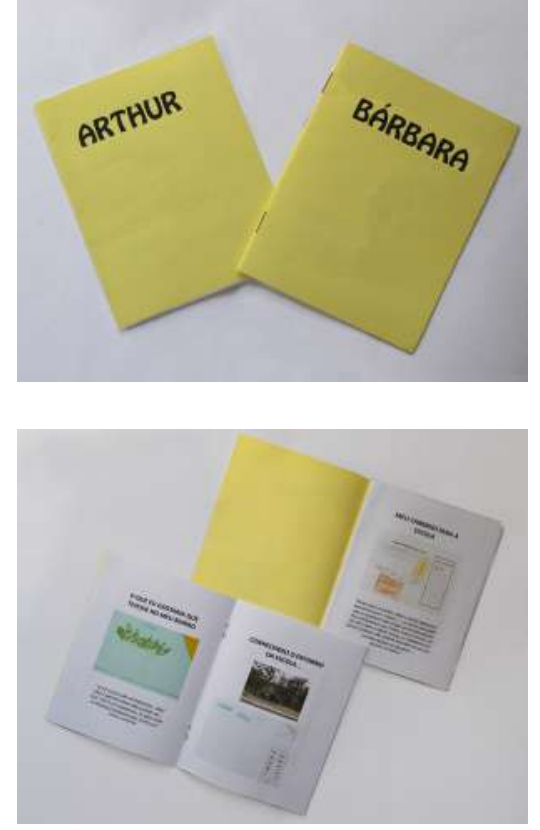

22 Os livrinhos foram materiais desenvolvidos individualmente para cada criança, contendo os registros e cópias das produções e fotografias produzidas por cada uma delas. A elaboração desse material se mostrou de grande importância dentro do processo de valorização da produção infantil e da individualidade de cada uma. Ainda que os materiais recebidos e produzidos por elas não foram analisados individualmente, devido aos propósitos da pesquisa, é importante considerá-los como expressões singulares, que carregam histórias e experiências únicas de vida. Os livrinhos também surgem de uma necessidade da pesquisadora em não caracterizar as oficinas e os trabalhos elaborados apenas para uso exclusivo da pesquisa, mas também como uma possibilidade das crianças terem consigo o registro das atividades desenvolvidas. 
Apesar das oficinas e atividades terem se organizado em três etapas, não se criou divisões rígidas entre elas, pois, cada uma foi permeada pelas demais, na medida em que as crianças carregam histórias e experiências de vida que refletem suas percepções de mundo. Ou seja, o processo de investigação, experimentação e expressão dos desejos e projetos estão pautados em vivências anteriores que se misturam nas manifestações presentes. Para Merleau-Ponty (2015), o sujeito é entendido como um corpo no mundo, onde toda a sua experiência de vida e todos os seus sentidos estão presentes no momento em que ele se coloca em contato com esse mundo. Ele destaca

[...] o fato de que o percebido por uma pessoa (fenômeno) acontece num campo do qual ela faz parte; a identidade do mundo percebido vai ocorrendo através das suas próprias perspectivas e vai se construindo em movimentos de retomada do passado e abertura para o futuro, sempre acessível a novas perspectivas. Desta maneira, diz-se que as coisas "se pensam" em cada pessoa, porque não é um pensar intelectual, na forma de funcionamento de um sistema, mas sim do saber de si ao saber do objeto, posto que ao entrar em contato com o objeto, o sujeito entra em contato consigo mesmo. (MASINI, 2012, p.17-18)

O percurso construído pelas oficinas, apesar de apresentar potencial educativo, não teve a intenção de criar uma prática ou uma teoria pedagógica, situa-se no campo e na visão de atuação urbanística e paisagística de transformação urbana a partir de processos participativos, nos quais os cidadãos exercem seus direitos para a construção de espaços e de uma sociedade mais democráticos.

As atividades propostas induziram a reflexões temáticas dentro da investigação sobre a cidade, possibilitando diferentes leituras da região do Jaraguá, construídas através dos elementos apresentados pelas crianças. Nesse sentido, evidenciaram e deixaram cada vez mais forte a importância das infâncias nos cenários urbanos, contrastando com a real invisibilidade que elas adquiriram, tanto nos espaços físicos da cidade quanto nas políticas públicas ligadas ao território. É curioso observar que com o aumento dos cuidados e da proteção às crianças, estamos, cada vez mais, impedindo que elas se construam com autonomia dentro das cidades. 
Das 13 atividades realizadas nas 10 oficinas, em 7 delas a proposta foi a elaboração de desenhos como forma de responder às questões colocadas pela pesquisa. As demais atividades trabalharam com a localização sobre foto aérea do bairro, visita ao entorno da escola com registro fotográfico, conversas sobre os espaços públicos e os usos possíveis na cidade, maquetes e bexigas de ar em que as crianças expressaram seus pedidos de transformação da cidade. Todas elas aprofundaram no universo infantil a fim de trazê-lo para a discussão acerca da produção dos espaços urbanos.

As atividades que se desenvolveram a partir da apresentação de imagens e de conversas com as crianças, trouxeram a aproximação dos conhecimentos infantis sobre a temática da cidade e de seus espaços a partir da escuta atenta de suas falas, possibilitando que elas contassem histórias vividas ou relatos vindos dos adultos. Essa postura foi importante para a aproximação do universo infantil, possibilitando que as crianças, assumindo o protagonismo da pesquisa e de seus papéis de sujeitos sociais e culturais, fornecessem informações diferentes daquelas trazidas pelos adultos. "É escutando que aprendemos a falar com eles [ou elas]. Somente quem escuta paciente e criticamente o outro, fala com ele [...]" (FREIRE, 2016, p.111) e, dessa forma, o coloca em posição de horizontalidade, considerando-o como sujeito de direito.

A pesquisa teve a "necessidade de conhecer as crianças a partir delas mesmas, ou seja, efetuar um exercício de observação, percepção, penetração, participação e interação com elas na configuração coletiva das condições de existência." (MARTINS FILHO; PRADO, 2011, p.9-10)

[...] o estudo das crianças a partir de si mesmas permite descortinar uma outra realidade social, que é aquela que emerge das interpretações infantis dos respectivos mundos de vida. 0 olhar das crianças permite revelar fenômenos sociais que o olhar dos adultos deixa na penumbra ou obscurece totalmente. [...] relativamente às metodologias selecionadas para colher e interpretar a voz das crianças, os estudos etnográficos, a observação participante, o levantamento dos artefactos e produções culturais da infância, as análises de conteúdo dos textos reais, as histórias de vida e as entrevistas biográficas, as 
genealogias, bem como a adaptação de instrumentos tradicionais de recolha de dados, como, por exemplo, os questionários, às linguagens e iconografias das crianças, integram-se entre os métodos e técnicas de mais frutuosa produtividade investigativa. (PINTO, SARMENTO, 1997, p.2723 apud GOBBI, 2009, p.69)

Apesar do desenho ter sido trabalhado em grande parte das oficinas e atividades como forma de manifestação infantil e resposta às questões apresentadas, as temáticas propostas possibilitaram diferentes formas de abordagem.

O desenho não será aqui entendido como um instrumento educacional ou como uma análise para estudar o desenvolvimento infantil, tal qual é feito por estudiosos do campo da psicologia e da pedagogia, mas será tratado como uma expressão da criança e valorizado enquanto elemento capaz de colocar os meninos e meninas como sujeitos de atuação e percepção protagonistas para o entendimento da cidade e das manifestações de seus desejos sobre os espaços públicos urbanos. Os desenhos foram retirados da "condição de objetos escolares-cotidianos" (LEITE, 2001, p.134) e, juntamente com a oralidade das crianças, foram explorados como expressões infantis que

[...] podem resultar em documentos históricos aos quais podemos recorrer ao necessitarmos saber mais e melhor acerca de seu mundo vivido, imaginado, construído, numa atitude investigativa que procure contemplar a necessidade de conhecer parte da História e de suas histórias segundo seus próprios olhares. [...] no qual seus olhares possam revelar fenômenos sociais que se encontram obscurecidos e cuja revelação contribuirá tanto para as pesquisas que estão sendo empreendidas, como para ações políticas que respeitem as crianças.

A perspectiva de que os desenhos infantis também podem ser considerados documentos deve-se ao peso que adquirem como informantes que são sobre determinados momentos históricos e sobre a infância existente nestes contextos. (GOBBI, 2009, p.73-74)

${ }^{23}$ PINTO, Manuel; SARMENTO, Manuel (Coords.). As crianças: Contextos e identidades. Braga: Instituto de Estudos da Criança da Universidade do Minho, 1997. 
entorno da escola.

Para a utilização desse recurso nas percepções infantis, é importante destacar que a leitura dessas imagens não deve ser feita como uma representação fiel da realidade. Como nos alerta Kossoy (2002), a fotografia é o produto do tema escolhido para ser retratado acrescido da visão e da história que o fotógrafo carrega, somados ao domínio da tecnologia e da técnica utilizada. Ou seja, a criança fotógrafa ao escolher um enquadramento carrega consigo todo seu domínio (ou não) de manuseio do objeto utilizado, suas questões culturais, sociais e experiências que pautam seu olhar enquanto está fotografando e assume uma postura política que irá influenciar diretamente no resultado obtido.

Assim como nos desenhos, as fotografias também refletem experiências e vivências das crianças nos espaços públicos da cidade e, ainda que não entendidos como cópias da realidade, mas representações dela,

o processo de criação é resultado de inúmeros fatores e o meio social e cultural estão fortemente presentes como experiências marcantes, são constituintes da história de vida, de um modo particular de interação com o mundo, de busca pela expressividade. É sempre relacional. (LEITE, 2001, p.110)

Outro recurso utilizado em uma das atividades foi a construção de maquetes que representassem os desejos de transformação da realidade. A escolha em trabalhar com esse instrumento possibilitou que as crianças se apropriassem de um repertório tradicionalmente utilizado como instrumento da arquitetura para lhes servir como mais uma forma de expressão.

A maquete dentro do processo de criação arquitetônica surge como o momento de concretização de uma ideia. Ainda que utilizada para estudo e não apenas para a conclusão de um projeto, a representação tridimensional torna real aquilo que antes era apenas uma abstração ou um desenho. 
Existe um momento mágico no processo de elaboração de um projeto de arquitetura: aquele em que os arquitetos têm que transformar os primeiros rabiscos em algo palpável, que possa ser olhado a distância, sob outro ângulo, a fim de aferir a validade dos princípios adotados num primeiro impulso criativo. (OTONDO e GRINOVER in. ROCHA, 2007, p.11)

Desse modo, ao trabalhar a construção de maquetes com os meninos e meninas, buscou-se também a criação de uma materialização de seus desejos, a fim de que eles pudessem visualizar espacialmente seus projetos para a cidade.

Além dessas formas utilizadas pelas crianças para conhecer e acessar suas leituras, investigações e proposições para a cidade, também julgou-se importante o contato com os adultos, os pais dos meninos e meninas sujeitos da pesquisa. No entanto, essa postura não teve a intenção de validar ou de sobrepor a visão do adulto sobre a visão infantil, mas conhecê-la como forma de verificar se as interpretações, as demandas e os pensamentos eram coincidentes e complementares ou se os pais construíram idealizações que não representavam os anseios de seus filhos. Como os objetivos dessa pesquisa não buscaram o aprofundamento nessa reflexão, os relatos dos pais não serão aqui trabalhados, mas poderão ser consultados ao final desse volume, na seção de Anexos.

Com base nas reflexões e produções decorrentes das oficinas aqui apresentadas, no capítulo seguinte aprofundaremos as leituras e os aspectos apontados pelas crianças a partir de suas investigações sobre a temática urbana, trabalhados tanto na escala do bairro e dos espaços cotidianos quanto na abrangência da cidade. 


\section{CAPÍTULO 3 \\ O JARAGUÁ E A CIDADE PELOS OLHOS DAS CRIANÇAS}

Acho que o quintal onde a gente brincou é maior do que a cidade. [...]. A gente descobre que o tamanho das coisas há que ser medido pela intimidade que

temos com as coisas. Há de ser como acontece com o amor. Assim, as pedrinhas do nosso quintal são sempre maiores do que as outras

pedras do mundo. Justo pelo motivo da intimidade.

Manoel de Barros ${ }^{24}$

${ }^{24}$ BARROS, Manuel. Memórias inventadas - a infância. São Paulo: Planeta, 2004. 


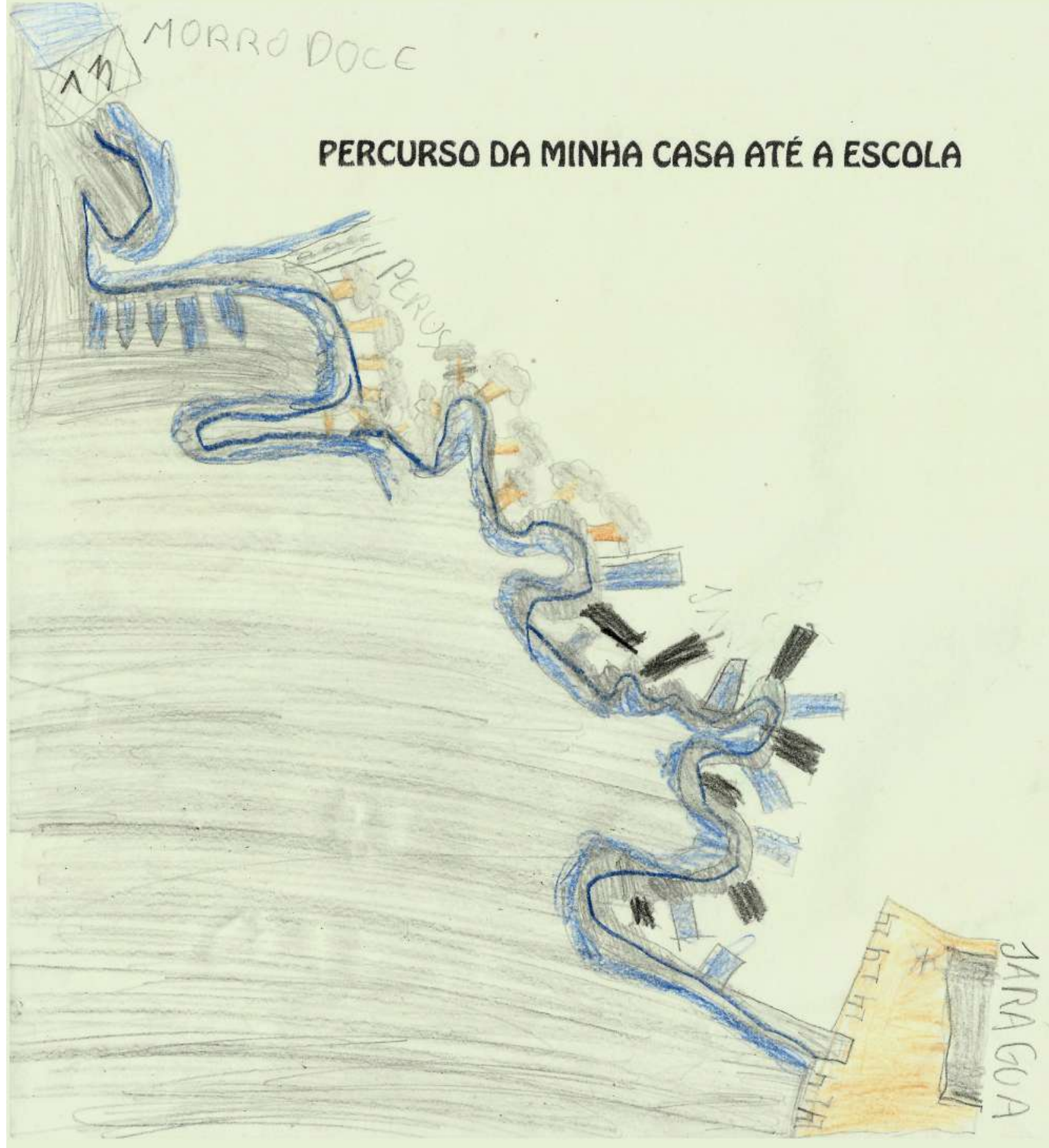

COMO EU FUI PARA A ESCOLA:

carro

O QUE EU SENTI:

calor 
FIGURA 44 [verso]

Desenho elaborado por Deyvid. Percurso realizado de carro de casa até a escola. Lápis de cor e grafite sobre papel sulfite na cor marfim, 210mm x 297mm, setembro de 2016 .

Fonte: Arquivo pessoal, 2016. 
25 Escola Municipal de Ensino Fundamental (EMEF) Dr. José Kauffmann

${ }^{26}$ olhos da rua é a expressão usada por Jane Jacobs para tratar a questão da segurança nos espaços públicos. Os olhos da rua são as pessoas que, estando nos espaços públicos ou podendo observá - los de suas casas, exercem uma certa vigilância natural sobre esses lugares. Quando os prédios são muito altos ou murados, impedindo o contato visual e a relação entre os espaços privados e públicos, essa situação de vigilância natural não pode ocorrer, gerando uma sensação de insegurança. Para mais informações, consultar: JACOBS, Jane. Morte e vida de grandes cidades. Tradução Carlos S. Mendes Rocha, 2a ed. São Paulo: WMF Martins Fontes, 2011.
"Ao adentrar o distrito do Jaraguá, nas proximidades do parque Pinheirinho d' Água, uma mistura de imagens e sensações aguçam-me os sentidos: ao fundo, a Serra da Cantareira, assumindo o protagonismo, surge como um mosaico colorido preenchido por inúmeras habitações que vão, cada vez mais, tomando conta do verde dos morros; a vista do Pico do Jaraguá aponta inesperadamente entre as frestas de alguns prédios ou diante de um ângulo privilegiado.

Saindo da estação de trem e me deslocando até o Kauffmann ${ }^{25}$, dentro de um micro-ônibus, observo atentamente tudo que acontece do lado de fora. As curvas do caminho acentuam-se e as paisagens vão se transformando a cada parada. Da Estação do Jaraguá, onde a chegada do trem é anunciada por um alarme que se assemelha às batidas de um sino, chego a uma rua agitada pelo comércio e pela grande movimentação de pessoas, que, muitas vezes, surpreendem o motorista do micro-ônibus com um cumprimento familiar. No período da manhã, noto muita gente em seus deslocamentos diários ao trabalho ou em atividades cotidianas nas ruas.

Algumas curvas adiante, deixando a rua de caráter marcadamente comercial, outra paisagem se destaca: remanescentes de áreas verdes surgem em meio a extensos muros que isolam os novos empreendimentos habitacionais (de promoção do mercado imobiliário) que chegaram na região nas últimas décadas. A diferença entre os conjuntos habitacionais construídos pelo Estado e pelo mercado imobiliário é nítida. Sem entrar no mérito de uma análise comparativa qualitativa entre seus projetos, reflito apenas sobre o impacto que eles causam aos espaços urbanos: enquanto os primeiros fazem uma interface com a cidade através de fechamentos vazados (grades), possibilitando uma abertura e um contato visual entre o que acontece dentro e fora dos espaços privados; os segundos afastam-se e isolam-se, cada vez mais, da cidade, criando extensas áreas muradas, impossibilitando que exista aquilo que Jane Jacobs chamou de olhos da rua ${ }^{26}$.

Percorrendo novas curvas no caminho, chego a uma das partes mais altas daquela área e a vista é inquietante: no vale, o Parque Pinheirinho d'Água surge cercado por conjuntos habitacionais, que parecem fazer pressão sobre ele. Muitas áreas verdes 
e a presença de árvores marcam todo esse trecho do percurso, no entanto, esses espaços não convidam ao desfrute da natureza; muitos aparentam estar abandonados e descuidados, criando, em alguns momentos, sensação de mistério e insegurança.

Próximo da escola, descendo o morro em direção ao vale, os predinhos da $\mathrm{CDHU}^{27}$ vão transformando novamente a paisagem e a presença de terrenos baldios e lixo nas ruas, a dividir as calçadas com os pedestres, tornam-se elementos frequentes. As ruas ficam menos movimentadas de automóveis e a presença de pessoas limita-se, quase que exclusivamente, aos moradores. Pequenos grupos de idosos (majoritariamente compostos por homens) e de rapazes sentados em bancos improvisados formam aquilo que Eugênio Queiroga chama de pracialidades ${ }^{28}$. As crianças presentes nas ruas, aparentemente, são aquelas que frequentam a escola no turno da tarde e, na maioria das vezes, estão acompanhadas por adultos deslocando-se para algum lugar.

As ruas percorridas são caracterizadas pelas figuras marcantes de prédios habitacionais baixos (cerca de cinco andares), de um lado, e casas autoconstruídas ou terrenos baldios remanescentes das construções, de outro. Alguns equipamentos públicos, como escolas, posto de saúde e um galpão comercial também complementam esse cenário.

Os conjuntos habitacionais são todos gradeados, mas um fato curioso, que chama a atenção, é a presença constante dos portões abertos. Seriam as grades apenas elementos simbólicos para criar uma sensação de segurança?

Ao chegar ao destino final, a escola, circundada por prédios, vejo uma rua tranquila e com poucos pedestres, mas sinto uma sensação de estar sendo observada por todas as janelinhas que se voltam para o espaço público. Ao fundo, apenas a Serra da Cantareira cortada pelas construções e o silêncio da rua quebrado pelos sons das crianças na escola."

(trecho extraído do caderno de campo da pesquisadora, elaborado durante as visitas à EMEF Dr. José Kauffmann para o desenvolvimento das Oficinas com as crianças. set., 2016)
${ }^{27}$ Companhia de Desenvolvimento Habitacional e Urbano

${ }^{28}$ pracialidade é o termo usado por Eugênio Queiroga que representa as atividades e ações que, caracteristicamente aconteciam nas praças - convívio, en contro e manifestações públicas -, mas que não mais se manifestam com exclusividade nesses espaços livres públicos. Para mais informações, consultar: QUEIROGA, Eugênio F. A megalópole e a praça: o espaço entre a razão de dominação e a razão comunicativa. Tese (doutorado) FAUUSP. São Paulo, 2002 
FIGURA 45 [verso]

Fotografia feita pelo grupo de Deyvid, Lívia e Pyetra durante visita ao entorno da escola. Em primeiro plano, cobertura da garagem dos edifícios habitacionais; em segundo plano, moradias auto-construídas e edificios habitacionais de promoção estatal; ao fundo a Serra da Cantareira. Máquina fotográfica digital, setembro de 2016.

Fonte: Arquivo pessoal, 2016 
Situado na região Noroeste do Município de São Paulo, o distrito do Jaraguá nome de origem tupi-guarani, que significa 'senhor do vale' - talvez mais conhecido por abrigar o Pico de mesmo nome, destaca-se entre remanescentes de mata ainda existentes na região, com enorme potencial paisagístico, e vem sendo fortemente fragmentado pela passagem do sistema rodoviário (Rodovias Anhanguera e

29 O trecho Oeste do Rodoanel Mário Covas foi inaugurado e entregue ao tráfego em outubro de 2002, com 32 quilômetros de extensão, fazendo a ligação entre a Avenida Raimundo Pereira de MagaIhães (estrada velha de Campinas) e a Rodovia Régis Bittencourt. O trecho norte, com 47,6 quilômetros, irá conectar os trechos Oeste e Leste, completando os 180 quilômetros de extensão previstos para todo o complexo. (Fonte: <http:// www.dersa.sp.gov.br/empreendimentos/rodoanel-mario-covas> e <http:// www.saopaulo.sp.gov.br/spnoticias/ rodoanel-autorizada-publicacao-de-edital-do-trecho-norte>. Acesso em 26 jan. 2018). No entanto, apesar de ainda não ser possível fazer uma análise mais aprofundada, a passagem do Rodoanel - Trecho Norte pela Serra da Cantareira, além de gerar um enorme e visível impacto ambiental, poderá facilitar o avanço da ocupação habitacional nessa área: fato que deverá ser observado e acompanhado a fim de preservar esse importante e significativo remanescente de Mata Atlântica no estado de São Paulo.

30 Dados presentes nos Cadernos das Subprefeituras - Material de apoio para Revisão Participativa dos Planos Regionais das Subprefeituras, Subprefeitura Pirituba-Jaraguá, de 2016, e no Plano Dietor Estratégico do Município, de 2014 ambos realizados pela Secretaria $\mathrm{Mu}$ nicipal de Desenvolvimento Urbano da Prefeitura de São Paulo, que se utilizaram de informações do Censo 2010 do IBGE (Instituto Brasileiro de Geografia e Estatística) e levantamentos fornecidos por outras secretarias municipais. Disponível em: <http://infocidade.prefeitura. sp.gov.br/>. Acesso em 26 jan. 2018
Bandeirantes e Rodoanel Mário Covas, trechos Oeste e Norte $\left.{ }^{29}\right)$, conectando-se aos municípios vizinhos. A área também tem como a principal ligação viária com o centro da cidade a Avenida Raimundo Pereira de Magalhães, cruzando-a em sua extensão norte-sul.

Ao norte, o distrito é fortemente marcado pela presença de áreas naturais onde ocorre a extração mineral, através das atividades de pedreiras ainda em funcionamento; a leste, a Serra da Cantareira, onde se localiza o Parque Estadual de mesmo nome, emoldura a paisagem; a oeste, o Parque Estadual do Jaraguá impõe o limite do distrito, também marcando fortemente as visuais do local; e ao sul uma enorme gleba de forte presença da natureza, que abriga o Jaraguá Clube Campestre e a Escola Superior de Soldados da Policia Militar, faz a divisa com Pirituba. Além dessas áreas e reservas naturais, a região ainda é circundada por significativas áreas verdes, como os parques municipais Anhanguera, São Domingos, Cidade de Toronto, Rodrigo de Gasperi, Jacintho Alberto e Jardim Felicidade, abrigando os parques municipais Pinheirinho d'Água, Senhor do Vale e Linear do Córrego do Fogo.

Com fortes carências no tocante ao atendimento das questões socioambientais ${ }^{30}$ a região é marcada pelo contraste entre extensas áreas habitacionais - conjuntos de promoção estatal, habitações autoconstruídas, assentamentos precários, favelas e loteamentos irregulares -, fragmentos ambientais e terrenos remanescentes das construções da Companhia de Desenvolvimento Habitacional e Urbano (CDHU) que, em sua maioria, encontram-se desqualificados pela falta de equipamentos e usos ou pela forte presença de lixo e entulhos depositados nessas áreas. Desse modo, reforça-se o paradoxo da grande demanda por espaços voltados ao lazer, à qualidade ambiental e urbana versus a existência de áreas desocupadas e degradas. 
De acordo com dados fornecidos pela Prefeitura Municipal de São Paulo ${ }^{31}$, o Jaraguá, comparado aos outros dois distritos - Pirituba e São Domingos pertencentes à mesma Prefeitura Regional de Pirituba-Jaraguá, é o que revela piores índices habitacionais de moradores em situação de risco, em domicílios localizados em favelas, em condições de inadequação domiciliar e de não atendimento por sistemas de água e esgoto conectados à rede de serviços.

Em 2010, o distrito apresentava 3368 moradores em situação de risco; 14,8\% dos seus domicílios localizados em áreas de favela, percentual superior à média do Município que era de 10,8\%; 14,6\% das residências em condições de inadequação, comparado aos $12,5 \%$ da taxa municipal; e índices de não atendimento sanitário e servidão de água encanada em 13,3\% e 2,0\% das habitações, respectivamente, sendo ambos também excedentes à média do Município, que representava 8,0\% e 0,9\%.

No entanto, no tocante à presença de áreas verdes, o Jaraguá, comparado à Pirituba e São Domingos, é o que possuí maiores extensões de cobertura vegetal e remanescentes florestais, fato que, somado aos piores índices habitacionais, tornase um elemento muito preocupante se considerarmos a ausência e a insuficiência de cuidados dirigidos à questão socioambiental.

A forma de ocupação do território, com grandes proporções de habitações irregulares e forte pressão sofrida pela expansão da mancha urbana com a chegada do mercado imobiliário, acrescida da carência de serviços sanitários e ambientais para o atendimento de toda a área, agrava e compromete a conservação dos remanescentes naturais, requerendo atenção especial em toda a extensão do distrito.

Entre os anos de 2000 e 2010, de acordo com o recenseamento realizado pelo IBGE (Censo 2010), a população do Jaraguá cresceu 2,39\%, atingindo 184.818 habitantes. A previsão para o ano 2018 é que a população ultrapasse os 216.000 habitantes, atingindo 317.439 moradores em $2040^{32}$.

Questões de grande precariedade referentes ao atendimento às condições básicas de infraestrutura urbana de saneamento, mobilidade, saúde, educação, cultura,
${ }^{31} \mathrm{Ibid}$.

32 Dados fornecidos pela Secretaria Municipal de Desenvolvimento Urbano - SMDU/ Departamento de Estatística e Produção de Informação - Dipro e Departamento de Produção e Análise de Informação - Deinfo, com base no IBGE Censos demográficos 1980, 1991, 2000 e 2010. Disponível em: <http:// infocidade.prefeitura.sp.gov.br/>. Acesso em 26 jan. 2018. 
lazer, moradia e aquelas relacionadas à retirada de terras indígenas e ao desrespeito com seus habitantes também compõem o complexo contexto no qual se insere essa área.

A cerca de $25 \mathrm{~km}$ do centro da capital paulista, o Jaraguá faz limites com os municípios de Osasco, a oeste, e Caieiras, a norte, relacionando-se diretamente com os demais distritos vizinhos - Brasilândia, Pirituba, São Domingos, Perus e Anhanguera. Esse distanciamento da região central de São Paulo, além de reforçado pela fragmentação gerada pelo sistema viário e pelo Rio Tietê, também fortalece no imaginário popular um sentimento de não pertencimento à essa cidade; fato muitas vezes explicitado nas falas dos moradores ao se referirem à região central: "vamos para São Paulo", como se o Jaraguá não pertencesse ao mesmo Município.

Não é de se estranhar que os habitantes de áreas mais periféricas, participem pouco dessa São Paulo que eles julgam não fazer parte. Além das distâncias e dos elementos físicos, como já mencionados anteriormente, a construção e a manutenção desse sentimento de não pertencimento são reforçadas pelas condições desprivilegiadas sob as quais vivem essas populações e pela baixa oferta e presença de transporte público de massa capaz de conectar e garantir a mobilidade para outras áreas da cidade. A região Noroeste do Município de São Paulo é servida por apenas uma linha de trem metropolitano (Linha 7 - Rubi, que faz o percurso Luz-Francisco Morato), cortando o território no sentido Norte-Sul, com apenas duas paradas no distrito do Jaraguá - Vila Aurora e Jaraguá.

[...] não são apenas os velhos que são vítimas da imobilidade, e esta, causada pela pobreza e baixos salários, resulta, também, pelas condições do lugar de residência que, na cidade, cabe aos mais pobres. Como os pobres se tornam praticamente isolados ali onde vivem, podemos falar da existência de uma metrópole [e uma cidade] verdadeiramente fragmentada. [...] Muitos, todavia, são prisioneiros do espaço local, enquanto outros apenas se movem para trabalhar no centro da cidade, fazer compras ou utilizar os serviços quando têm a possibilidade e os meios. 
A imobilidade de tão grande número de pessoas leva a cidade a se tornar um conjunto de guetos e transforma sua fragmentação em desintegração. (SANTOS, 1990, p.89-90)

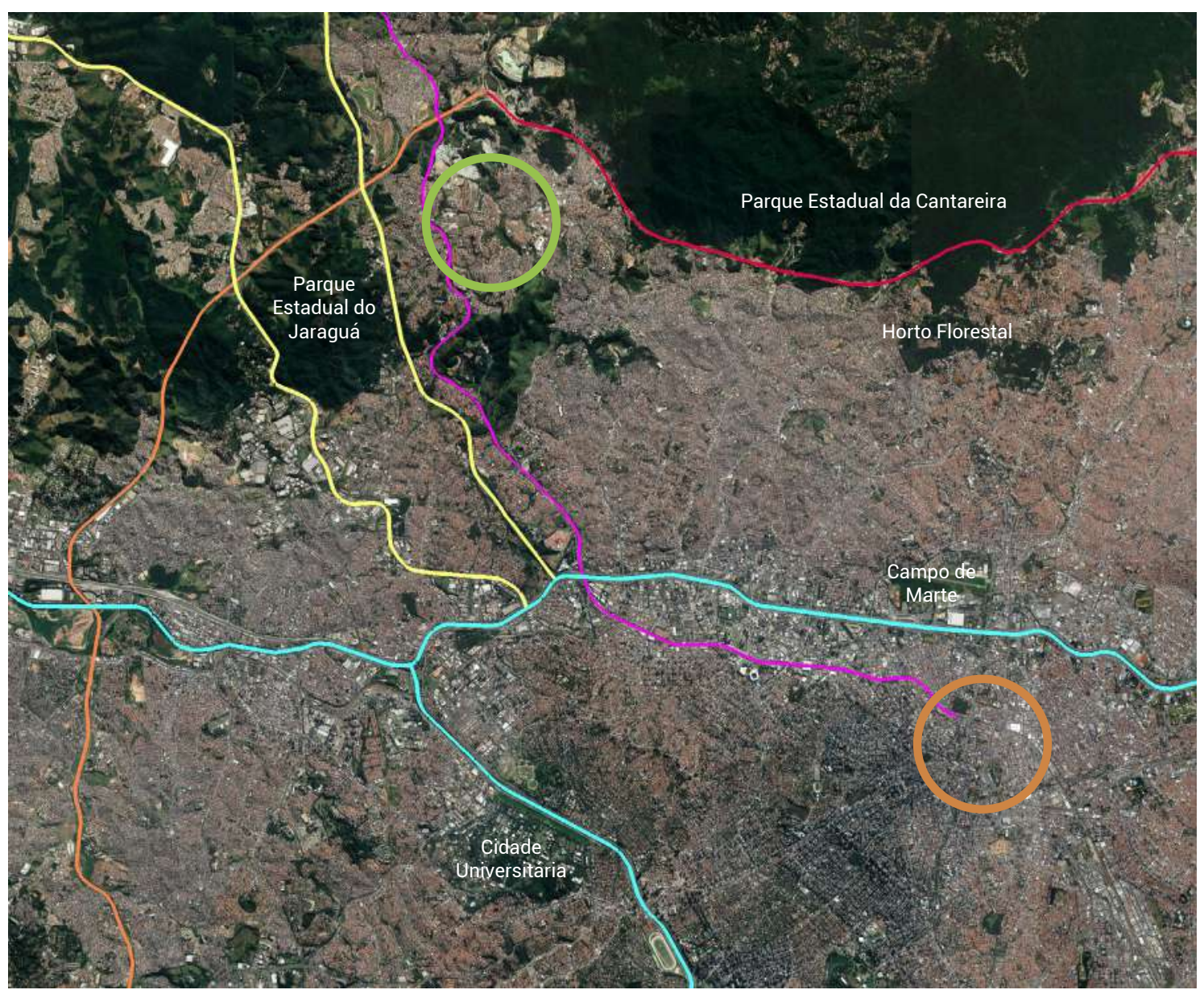

LEGENDA

Rodovias Anhanguera e Bandeirantes

- Marginais dos Rios Tietê e Pinheiros

Rodoanel trecho Oeste

- Rodoanel trecho Norte (em construção)

_Linha 7 - Rubi da CPTM
FIGURA 46

Localização da área de estudo sobre foto aérea.

Fonte: Google Earth, out. 2017. 
${ }^{3}$ De acordo com dados apresentados pela Secretaria Municipal de Desenvolvimento Urbano/SMDU - Departamento de Produção e Análise de Informação - Deinfo, em 2016, a população de crianças e jovens entre 0 e 14 anos era 51.576, do total de 208.052 habitantes no distrito do Jaraguá. Disponível em: <http://infocidade.prefeitura.sp.gov.br/>. Acesso em 26 jan. 2018.

${ }^{34}$ Ibid.

${ }^{35}$ Para maiores informações sobre o histórico e o processo de construção da área de estudo trabalhada nessa pesquisa consultar: BOUCINHAS, Caio; LIMA, Catharina Pinheiro C. S. Parque Pinheirinho d'Água: a luta por reconhecimento e visibilidade. Pós. Revista do Programa de Pós-Graduação em Arquitetura e Urbanismo da FAUUSP, São Paulo, v.20, n.33, p.11-34, 2013. Disponível em: <http://www.revistas.usp. br/posfau/article/ view/80918/84560>. Acesso em: 15 jan. 2018.
Na composição etária do Jaraguá, a presença de crianças e adolescentes, entre 0 (zero) e 14 anos, é muito forte, representando quase $25 \%$ dos moradores ${ }^{33}$. Não sendo apenas o reflexo de uma taxa de natalidade mais elevada, as maiores concentrações de crianças nas periferias também chamam a atenção para a necessidade de investimentos em equipamentos destinados ao atendimento das demandas relacionadas a essa faixa etária.

Dentro da Prefeitura Regional de Pirituba-Jaraguá, o distrito do Jaraguá é o que apresenta maior concentração de crianças $^{34}$, fortalecendo a importância dessa pesquisa, que investiga suas relações com a cidade, a partir de suas percepções, apropriações e participação nos espaços públicos urbanos.

Diante de um processo singular de formação da área, que contou com a participação popular para a conquista de melhorias nas condições urbanas ${ }^{35}$, cabe, aqui, desenvolver uma reflexão sobre o direito à cidade enquanto possibilidade de construção desse espaço, vislumbrando novas alternativas de conquistas e transformações sociais.

Os propósitos desse capítulo não buscam uma análise aprofundada do Jaraguá como um todo, tampouco estender-se à toda a diversidade e complexidade política, social, cultural e urbana colocadas por esse território. Propõe-se aqui levantar e investigar a temática dos espaços livres públicos, no tocante as questões manifestadas pelas crianças durante as oficinas apresentadas no capítulo anterior, e como estes elementos podem ser trabalhados, direta ou indiretamente, pelo campo da arquitetura, do urbanismo e do paisagismo, relacionando-se com a multiplicidade de disciplinas e temas que envolvem as infâncias e os espaços urbanos. Os limites de abordagem do Jaraguá foram determinados pelos meninos e meninas a partir de seus conhecimentos e vivências nesse território, o que justifica uma concentração maior de reflexões sobre os bairros do Jardim Rincão, City Jaraguá, Parque Nações Unidas e Parque Panamericano, onde se localizam suas moradias e a escola em que estudam.

Uma 'simples' proposta de desenhar o percurso de casa até a escola, pode 
revelar uma infinidade de leituras e abordagens trazidas pelas crianças ao observar seus espaços cotidianos.

O desenho escolhido para a abertura desse capítulo foi produzido por Deyvid, um dos meninos participantes das oficinas. A escolha desse material se fez por ser o único a retratar com maior abrangência a região Noroeste. As demais crianças, por possuírem vivências cotidianas mais restritas ao distrito do Jaraguá, sobretudo nos bairros listados anteriormente - fato que pôde ser constatado durante as atividades propostas -, trouxeram em seus desenhos aspectos mais limitados aos bairros situados no entorno da escola.

O percurso diário de Deyvid até a escola envolve a passagem por três distritos diferentes da região Noroeste de São Paulo - Anhanguera, Perus e Jaraguá - cada qual com características particulares que os define. 0 bairro do Morro Doce, no distrito Anhanguera, onde o menino mora, é um local formado majoritariamente por casas, segundo sua visão. Mesmo sem conhecer pessoalmente tal bairro, ao entrar em contato com ele através de fotos e informações, o desenho de Deyvid ganha toda a fidelidade representada. Em sua passagem por Perus, a composição da cidade se altera completamente e a presença dominante de árvores passa a tomar conta do desenho. Perus, que no imaginário pode remeter a um distrito também formado por muitas construções habitacionais, tal qual o Morro Doce, ganha outra aparência nos limites com a Rodovia dos Bandeirantes e o trecho oeste do Rodoanel Mario Covas, próximo ao Aterro Sanitário Bandeirantes, onde, possivelmente, passa o percurso realizado pelo menino, cruzando áreas fortemente marcadas por remanescentes de mata e massas arbóreas significativas, conforme sua representação. Ao aproximar-se da escola, já no distrito do Jaraguá e, sobretudo em seu entorno, o desenho de Deyvid assume outra configuração: prédios habitacionais se tornam predominantes até sua chegada ao destino final. 0 trecho representado no desenho, mais especificamente o bairro City Jaraguá, que recebe esse nome devido aos conjuntos habitacionais de mesmo nome existentes no local, tem uma presença marcante de construções promovidas pelos governos estadual e municipal, tal qual representado pelo menino. 


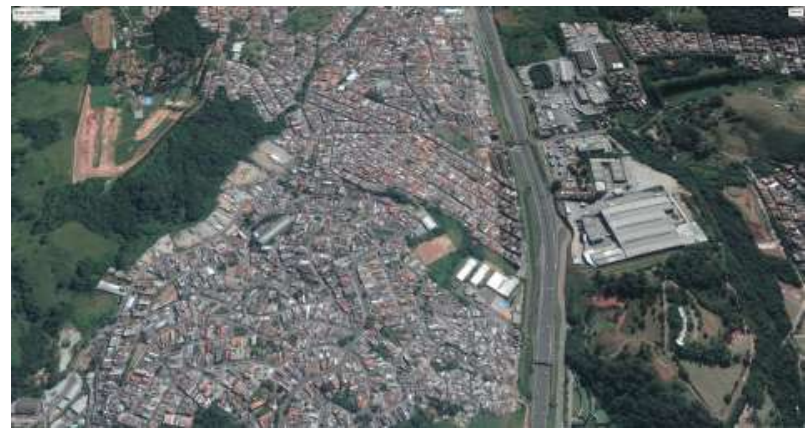

Foto aérea da região de Perus.

Fonte: Google Earth, 2017.

FIGURA 50 [centro direita]

Fotografia de Perus.

Fonte: Regional News, 2014.

FIGURA 51 [inferior esquerda]

Foto aérea da região do Jaraguá. Fonte: Google Earth, 2017.

FIGURA 52 [inferior direita]

Fotografia do Jaraguá.

Fonte: Edson Vieira/Folha Noroeste, 2016.
MORRO DOCE

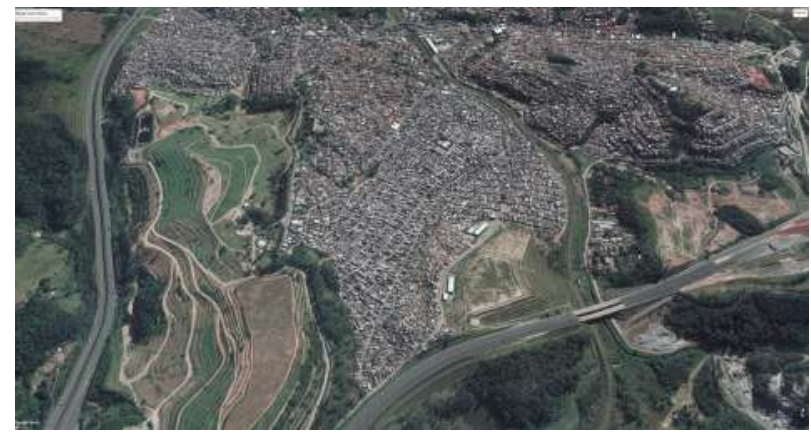

PERUS
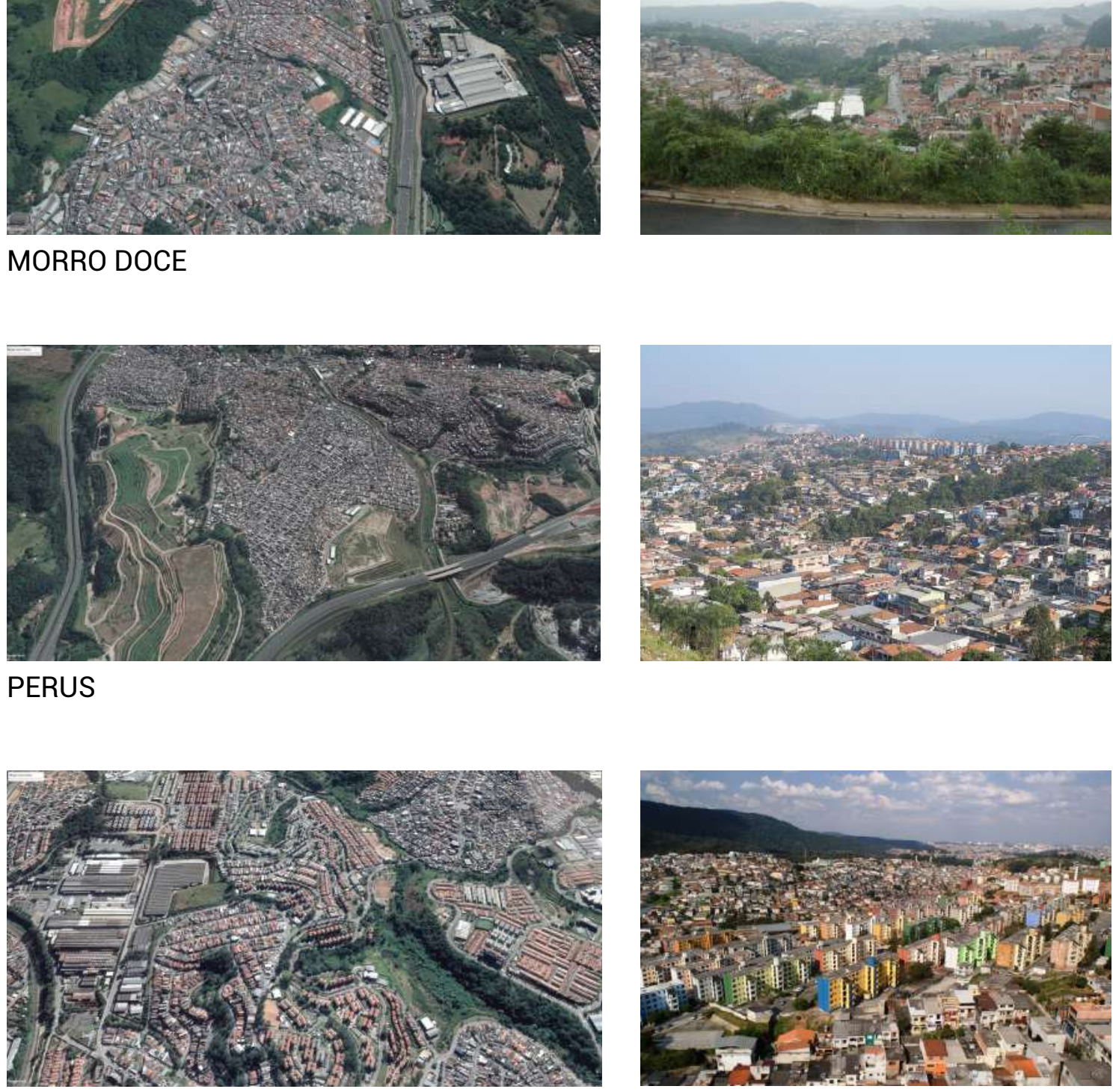

JARAGUÁ 
Observando o conjunto de desenhos elaborados pelas crianças dentro da proposta de registro do percurso de casa até a escola, não se pode dizer que há uma regra para aqueles que o fizeram de carro e para aqueles que o realizaram a pé. Ainda que a experiência de estar e vivenciar o espaço público enquanto pedestre traga uma riqueza de possibilidades e trocas marcantes, não é possível afirmar que os percursos realizados dentro de um automóvel, seja o carro de familiares ou o transporte escolar coletivo, proporcione uma percepção menos detalhada da cidade, já que essa é vista à distância e intermediada por um veículo automotivo. Da mesma forma, não se pode generalizar acreditando que o caminhar pelos espaços públicos garante uma visão mais atenta e cuidadosa daquilo que é visto. 0 estar na rua, deslocando-se a pé ou por meio de um automóvel, possibilita experiências urbanas distintas, com leituras, interpretações e percepções que irão refletir e construir as crianças enquanto sujeitos presentes nesses espaços, ao mesmo tempo em que os transformam a partir de suas presenças.

Os desenhos são formas de expressão e interpretação simbólica do mundo, que representam e refletem aquilo que as crianças são - com seus medos, inseguranças, sonhos e desejos - a partir dos contextos sociais, culturais e históricos nos quais estão inseridas. Desse modo, não é possível tratá-los de maneira objetiva, apenas olhando para aquilo que está presente no papel, a oralidade que os acompanha se torna um elemento fundamental para sua compreensão. (GOBBI, 2009; SARMENTO, 2011) No entanto, a proposta desse trabalho não é formular uma análise de cada criança através de seus desenhos nem aprofundar em cada uma das produções; o objetivo é trazê-los como material de investigação para entender as representações de mundo que eles comunicam, a partir da cidade vivenciada e interpretada pelos meninos e meninas, tendo por base as temáticas sugeridas nas oficinas.

Na sequência serão apresentados quatro desenhos selecionados dentro da Oficina 01 percurso de casa até a escola. Nesses, os espaços cotidianos percorridos diariamente, a pé ou em veículos motorizados, trazem e expressam as percepções das crianças nesse trecho da cidade.

Convido também o leitor a retomar algumas páginas para observar, novamente e com maior atenção, o desenho de abertura desse capítulo, criado por Deyvid, que traz uma riqueza de detalhes e percepções das paisagens urbanas, observadas através da janela de um automóvel. 


\section{PERCURSO DA MINHA CASA ATÉ A ESCOLA}

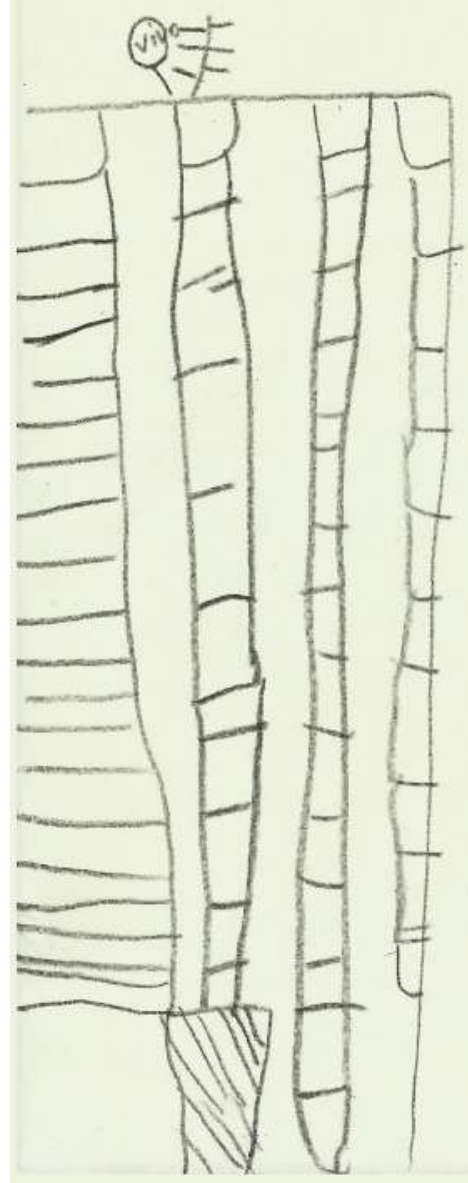

$A P \hat{E}$

O QUE EU SENTI:

FELISIDADE 
FIGURA 53 [verso]

Desenho elaborado por Pyetra. Percurso realizado a pé de casa até a escola. Lápis de cor e grafite sobre papel sulfite na cor marfim, $210 \mathrm{~mm} \times 297 \mathrm{~mm}$, setembro de 2016.

Fonte: Arquivo pessoal, 2016 


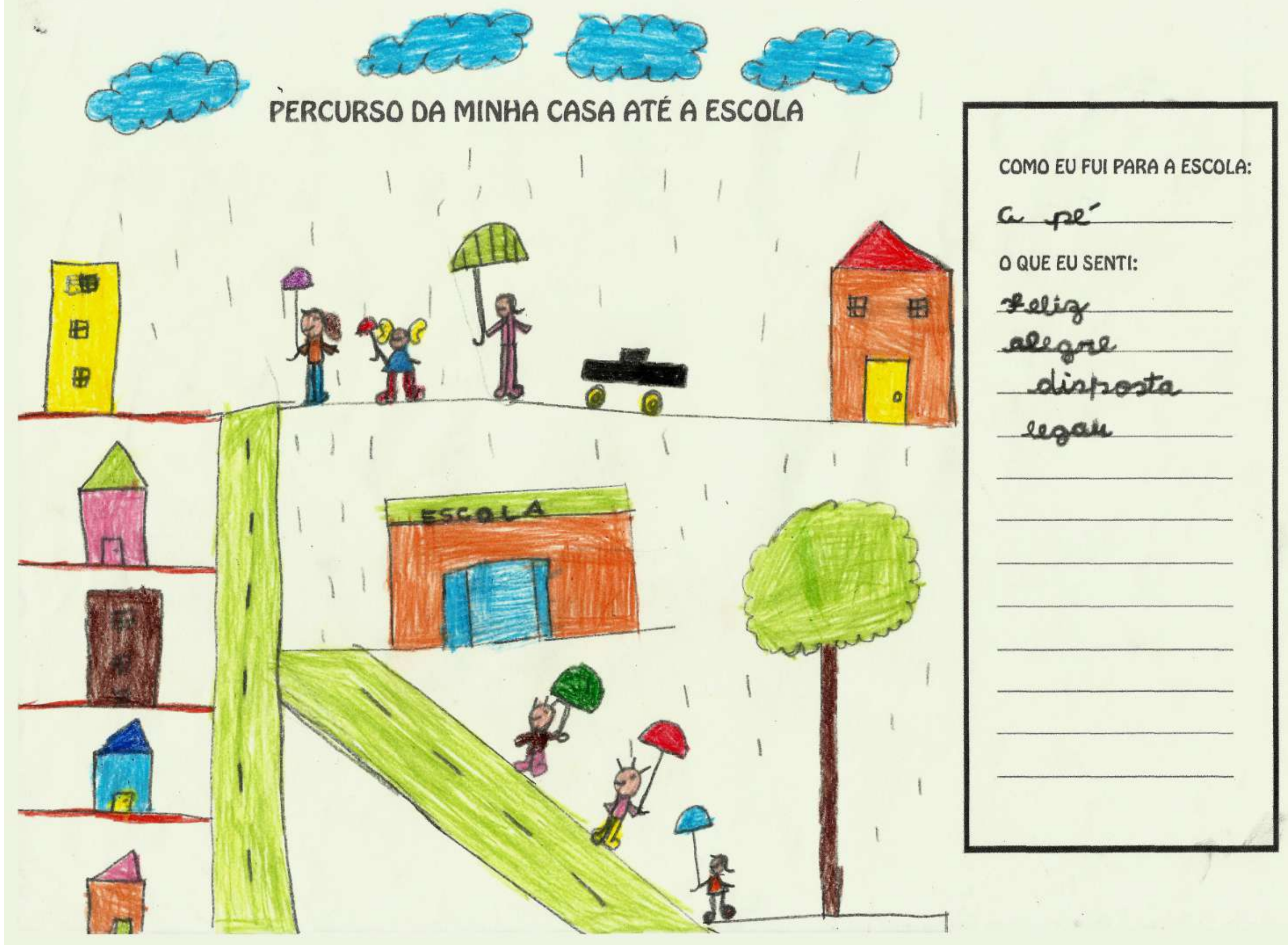


FIGURA 54 [verso]

Desenho elaborado por Thayná. Percurso realizado a pé de casa até a escola. Lápis de cor e grafite sobre papel sulfite na cor marfim, $210 \mathrm{~mm} \times 297 \mathrm{~mm}$, setembro de 2016 .

Fonte: Arquivo pessoal, 2016. 


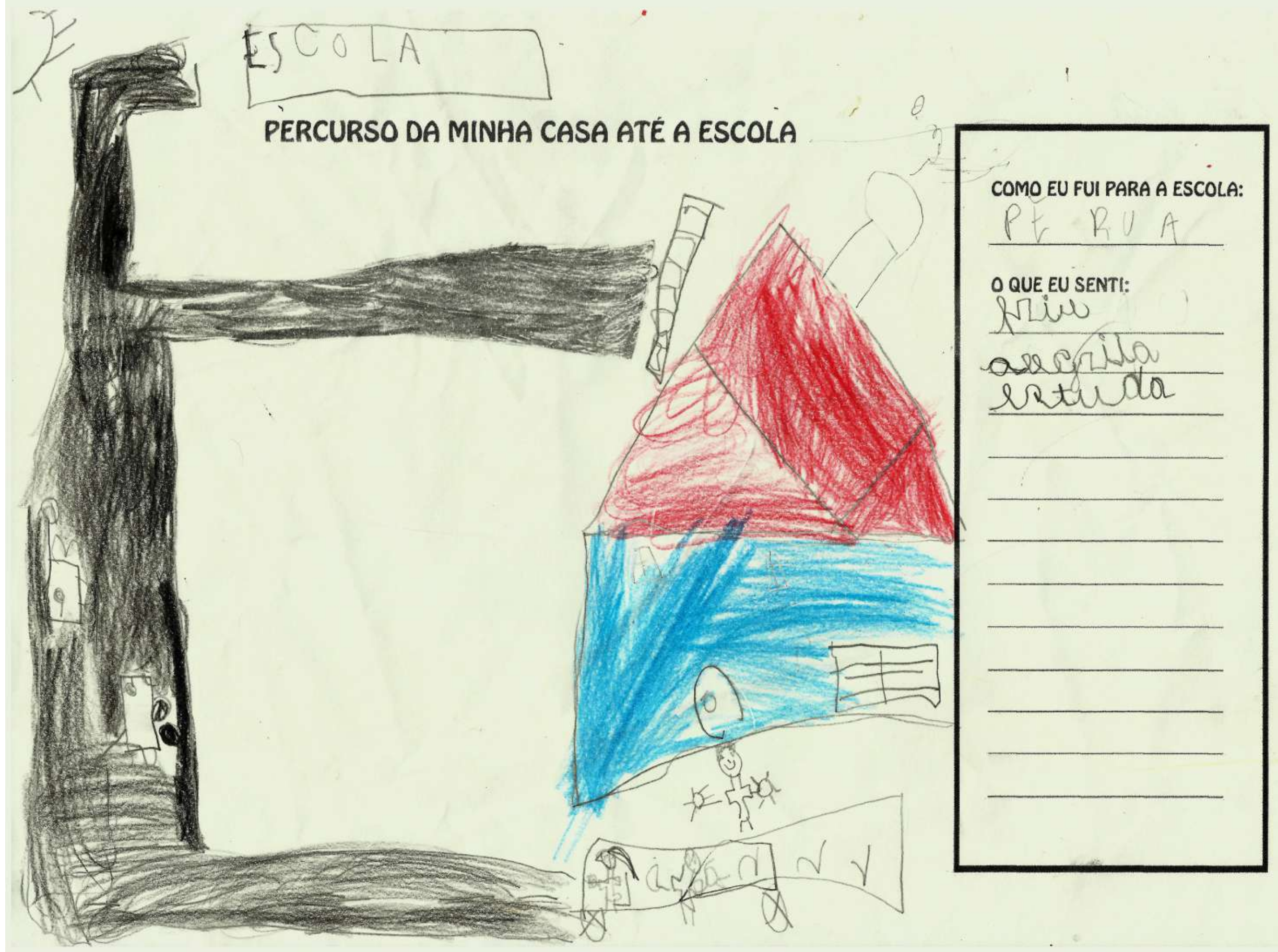


FIGURA 55 [verso]

Desenho elaborado por Kauê. Percurso realizado de transporte escolar (perua) de casa até a escola. Lápis de cor e grafite sobre papel sulfite na cor marfim, 210mm x 297mm, setembro de 2016.

Fonte: Arquivo pessoal, 2016. 


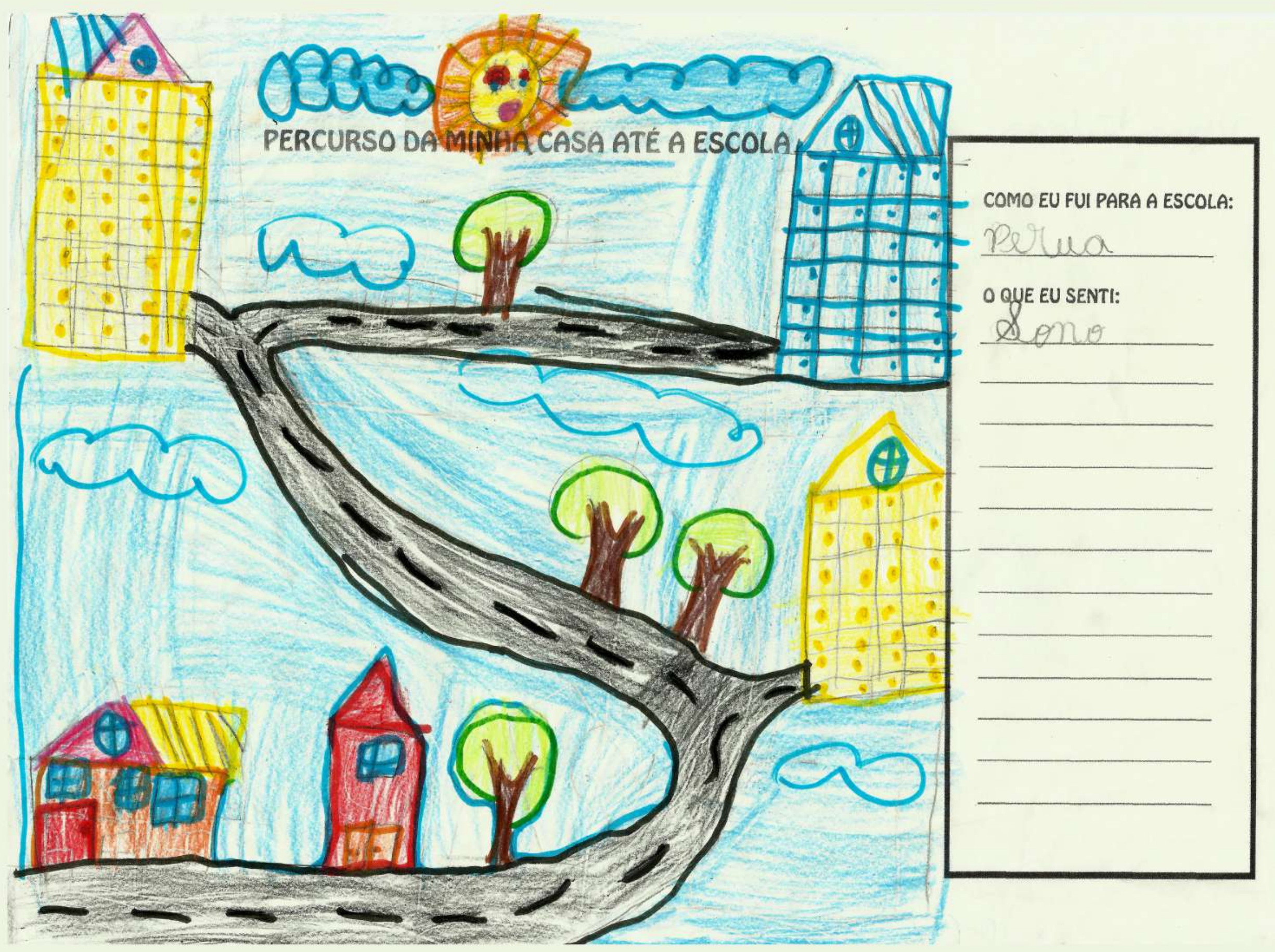


FIGURA 56 [verso]

Desenho elaborado por Maria Vitória. Percurso realizado de transporte escolar (perua) de casa até a escola. Canetinha hidrogáfica, lápis de cor e grafite sobre papel sulfite na cor marfim, $210 \mathrm{~mm} \times 297 \mathrm{~mm}$, setembro de 2016.

Fonte: Arquivo pessoal, 2016 
Não apenas a materialidade das edificações ou a presença de elementos naturais marcam as leituras das crianças sobre seus territórios cotidianos. Essa aproximação inicial, ligada primeiramente ao concreto e aquilo que é visível em sua materialidade, carrega um simbolismo e uma interpretação mais aprofundada dos problemas e das questões apresentados pela região, que não escapam à percepção infantil.

A partir dos processos e das pesquisas realizados por elas, que foram motivados pelas oficinas desenvolvidas nesse trabalho, muitas respostas surgiram indicando a possibilidade de diferentes leituras dos espaços urbanos vividos por cada menino e menina. São abordagens que podem ser mais técnicas e comparativas com dados e índices oficiais, até uma aproximação mais sensível e individual de cada representação. A escolha dos temas que serão trabalhados foi feita a partir das visões infantis apresentadas e do entendimento das crianças como pesquisadoras, tendo como ponto de partida a cidade em seus espaços livres públicos e naquilo que reflete social, política e culturalmente as conformações, significados e usos dados a ela.

Os assuntos apresentados a seguir, que surgiram das produções e da oralidade das crianças em suas leituras do distrito do Jaraguá e da cidade de São Paulo, muitas vezes, podem ser vistos como apartados de uma elaboração e percepção infantis, ainda que a presença da infância seja marcante nestas temáticas. 


\section{1 "São Paulo tem condomínios e prédios ricos com piscinas" - leitura das desigualdades}

[fala de uma das crianças participantes das oficinas, quando questionada sobre "o que tem na cidade de São Paulo"]

A desigualdade se reflete espacialmente na forma de produção da cidade, sendo decorrente de um processo social, econômico e político que cria espaços diferenciados e privilegiados para atender às camadas mais altas, garantindo acesso a determinados bens e equipamentos, em detrimento das camadas mais carentes. Segundo Villaça (2012, p.288), "nenhuma análise do espaço urbano será jamais entendida se não houver uma articulação entre o social e o espaço urbano."

Durante as oficinas realizadas com as crianças, essa desigualdade assumiu diferentes feições, desde o apontamento às diferenças do padrão de habitação entre as classes de maior poder aquisitivo e aquelas mais carentes, nas quais elas estão inseridas, até a identificação de questões particulares, no qual a restrição financeira familiar impede $o$ acesso a determinados equipamentos e eventos de grande interesse para o universo infantil. Nesse aspecto, Villaça (2012, p. 285) também chama a atenção para o processo de individualização das questões sociais que "transfere para a esfera individual um problema que é social, ou seja, transfere-o do âmbito da sociologia para o campo da psicologia."

Historicamente, a cidade de São Paulo foi se construindo de forma dinâmica, atingindo diferentes significados com as mudanças sociais, principalmente após o advento da indústria e a expansão dos veículos automotivos. Nesse contexto, favorecido por tais processos principalmente no século XX, São Paulo cresceu intensificando a produção e a distinção de espaços urbanos centrais e periféricos, onde os primeiros passaram a receber maiores investimentos e obras de infraestrutura e os segundos foram vítimas do insuficiente atendimento das políticas públicas. 


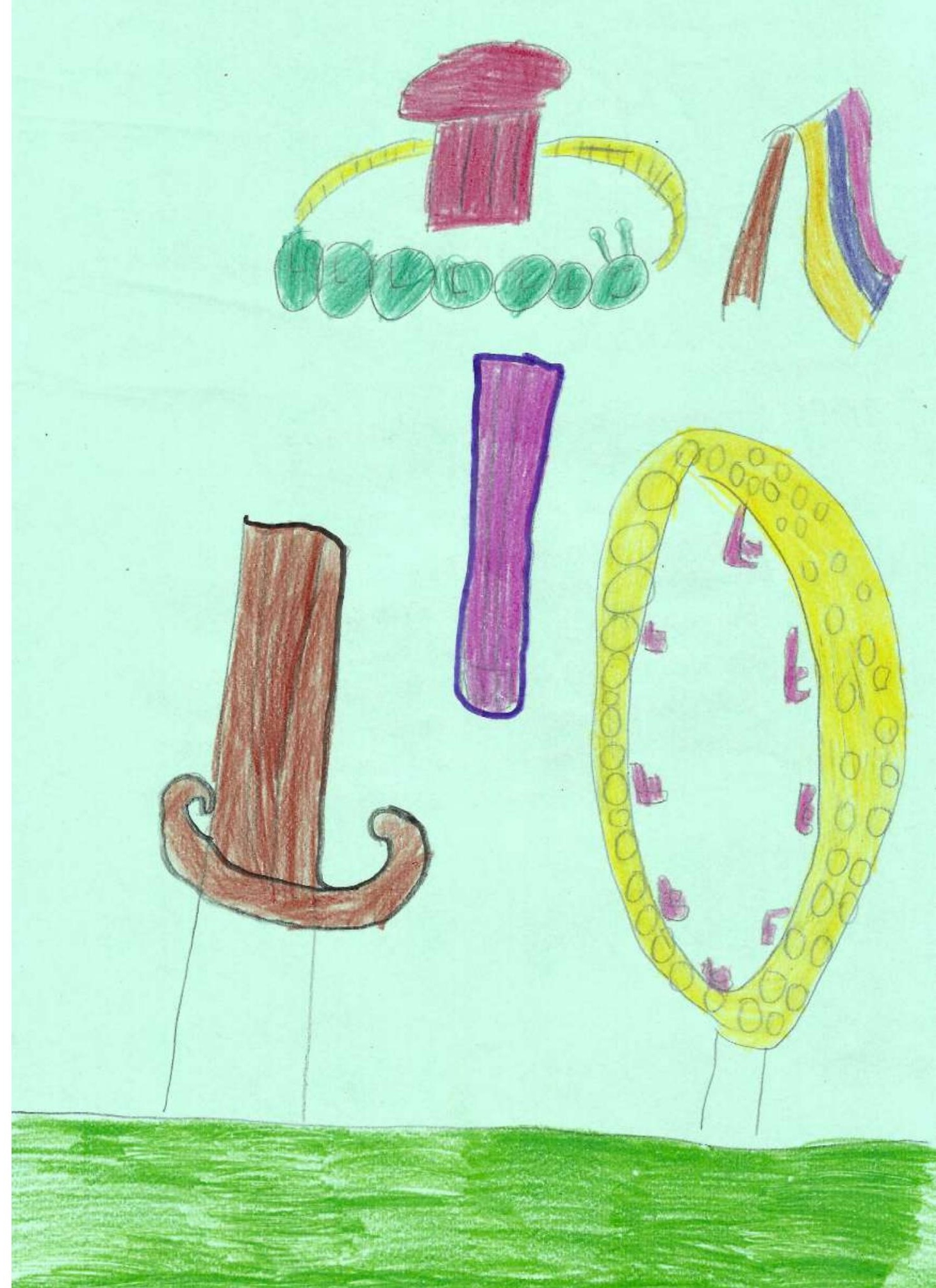


"Eu gosto bastante de parque de diversões! Meu pai me falou que ia me levar no parque, mas depois não me levou porque é muito caro." (Yasmin)

\section{FIGURA 57 [verso]}

Desenho elaborado por Yasmin. Parque de diversões, em resposta ao questionamento sobre 'o que você gostaria que tivesse no seu bairro?' Canetinha hidrográfica, lápis de cor e grafite sobre papel sulfite na cor verde, $210 \mathrm{~mm} \times 297 \mathrm{~mm}$, outubro de 2016 .

Fonte: Arquivo pessoal, 2016. 
DEBORAD

$$
\text { as } * \text { ans }
$$<smiles>C1C2CC3OOC1C3O2</smiles> 
"Eu desenhei uma festa de aniversário, porque minha mãe nunca fez uma festa pra mim e, por isso, eu gostaria de ter." (Débora)

\section{FIGURA 58 [verso]}

Desenho elaborado por Débora. Festa de aniversário, em resposta ao questionamento sobre 'o que você gostaria que tivesse no seu bairro?' Canetinha hidrográfica, lápis de cor e grafite sobre papel sulfite na cor verde, $210 \mathrm{~mm} \times 297 \mathrm{~mm}$, outubro de 2016.

Fonte: Arquivo pessoal, 2016. 
No entanto, vale destacar que as distinções e desigualdades espaciais das áreas urbanas não se limitam apenas a uma abordagem de centro versus periferia, pois essa leitura limita e não considera a influência econômica e política na produção do território urbano, ou seja, impossibilita um entendimento de que a cidade se forma e se desenvolve onde há interesses das classes dominantes. Em São Paulo ocorreu uma expansão e um direcionamento dos investimentos públicos, políticos e econômicos voltados para o sudoeste paulistano - o chamado Quadrante Sudoeste - em detrimento das demais regiões da cidade, onde se localizam as periferias. Dessa forma, torna-se importante analisar a cidade a partir de regiões e não por bairros, pois os interesses comuns ou os aspectos da segregação se concentram em áreas dentro do meio urbano. (VILLAÇA, 2012).

No caso particular das cidades brasileiras, é indispensável articular o papel da segregação urbana na produção da desigualdade e da dominação sociais. Isso porque a segregação é aquela forma de exclusão social e de dominação que tem uma dimensão espacial. (VILLAÇA, 2012, p.49).

Nesse cenário, a região Noroeste do Município de São Paulo vai se constituindo através de um acelerado processo de expansão territorial, em uma extensa área de conjuntos habitacionais de promoção estatal, habitações autoconstruídas e ocupações de terrenos por favelas, em detrimento de um planejamento que contemple as questões ambientais e os espaços públicos para o atendimento das demandas da população.

${ }^{36}$ De acordo com dados presentes nos de apoio para Revisão Pa Planos Regionais das Subprefeituras, Subprefeitura Pirituba-Jaraguá, de 2016, realizados pela Secretaria Municipal de Desenvolvimento Urbano da Prefeitura de São Paulo, que se utilizaram de informações do Censo 2010 do IBGE (Instituto Brasileiro de Geografia e Estatística) e levantamentos fornecidos por outras secretarias municipais, o distrito do Jaraguá apresentava, em 2014, 21,4\% de seus terrenos vagos. Disponível em: <http://infocidade.prefeitura.sp.gov.br/> Acesso em 26 jan. 2018.
Desse modo, cria-se uma enorme quantidade de terrenos vagos ${ }^{36}$, fragmentos ambientais resultantes das ocupações habitacionais e áreas públicas desqualificadas que passam a servir como depósitos de lixo e entulhos

Sem ter onde morar, os pobres da cidade foram sendo obrigados a aceitar condições de habitação cada vez mais penosas. Acantonados nas favelas e cortiços ou deslocados para longínquas periferias, tinham de submeter-se, de bom ou mau grado, a todo o tipo de privações. A precariedade dos transportes coletivos; a insuficiência do abastecimento; a inexistência de água, luz e gás; a ausência total de condições adequadas de saneamento básico; a rarefação da rede escolar; a falta ou o desaparelhamento dos postos de saúde; a 
restrição das opções de lazer e, finalmente, a violência e a poluição ambiental constituem um inventário que, não sendo exaustivo, ilustra bem essas vicissitudes. (VOGEL, 1995, p.XII)

Durante a oficina em que as crianças identificaram, sobre a foto aérea, a localização de suas casas e de equipamentos existentes nos bairros, foi possível visualizar a existência de quatro tipologias de habitações entre os meninos e meninas: condomínios habitacionais verticais de promoção estatal; condomínio residencial horizontal com acesso controlado (City Jaraguá); residências autoconstruídas; e moradias em favela.

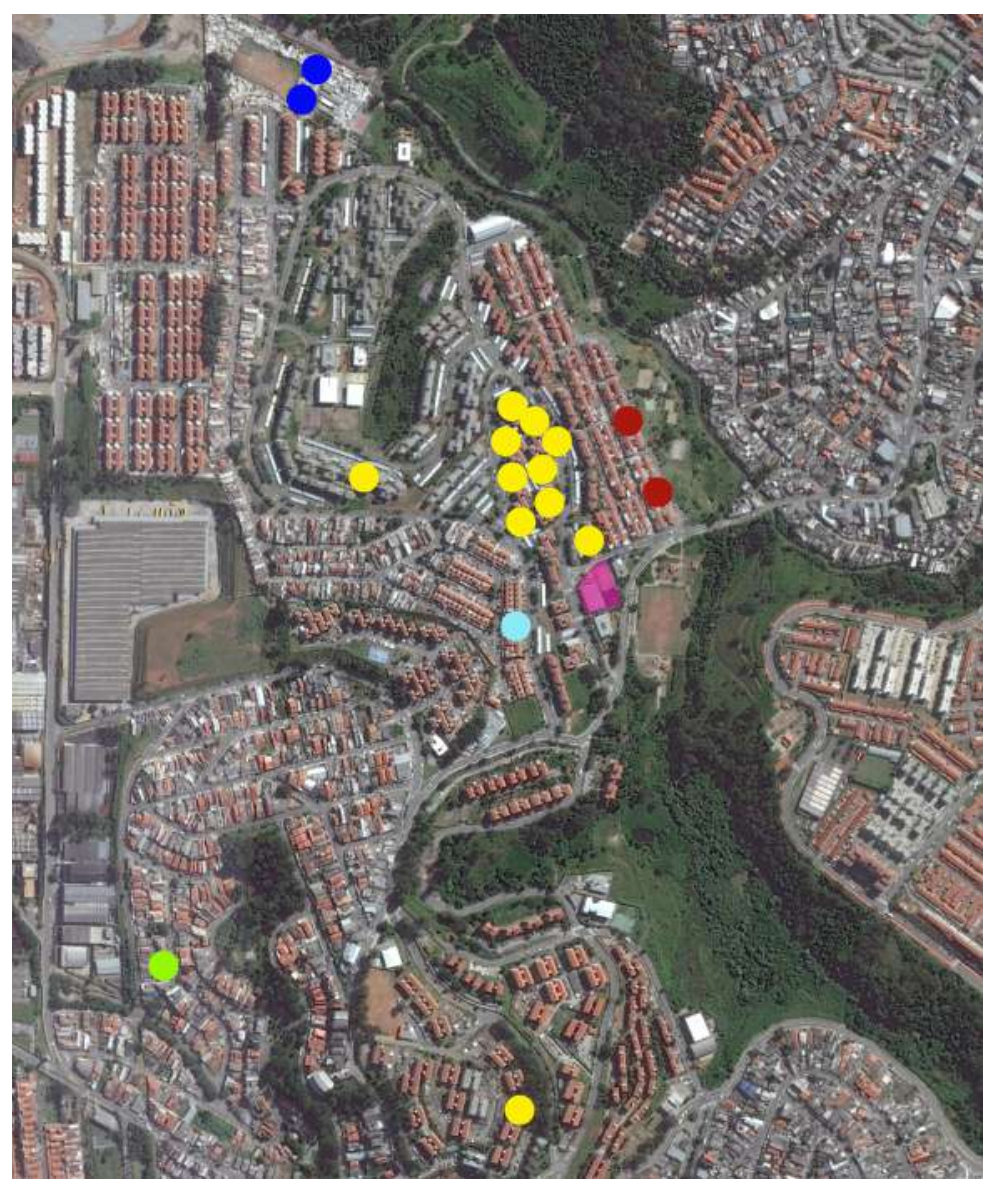

\section{LEGENDA}

EMEF Kauffmann

Padrões de moradias das crianças participantes das oficinas:

Condomínios habitacionais verticais de promoção estatal (CDHU e Sehab)

Condomínio residencial horizontal City Jaraguá (com acesso controlado)

Conjunto habitacional horizontal City Jaraguá (em via pública)

Habitação autoconstruída

Habitação em favela
FIGURA 59

Identificação e localização das casas das crianças sobre foto aérea. Etiquetas coloridas sobre foto aérea; Oficina 04.

Fonte: Google Earth, 2016 
FIGURA 60 [superior esquerda]

Fotografia feita pelo grupo de Gustavo e Izabela durante visita ao entorno da escola. Máquina fotográfica digital, setembro de 2016.

Fonte: Arquivo pessoal, 2016.

FIGURA 61 [superior direita]

Fotografia feita pelo grupo de Danilo e Gabriel durante visita ao entorno da escola. Máquina fotográfica digital, setembro de 2016.

Fonte: Arquivo pessoal, 2016.

\section{FIGURA 62 [inferior esquerda]}

Fotografia feita pelo grupo de Deyvid, Lívia e Pyetra durante visita ao entorno da escola. Máquina fotográfica digital, setembro de 2016. Fonte: Arquivo pessoal, 2016.

\section{FIGURA 63 [inferior direita]}

Fotografia feita pelo grupo de Gustavo e Izabela durante visita ao entorno da escola. Máquina fotográfica digital, setembro de 2016 . Fonte: Arquivo pessoal, 2016
De acordo com dados fornecidos pela EMPLASA (Empresa Paulista de Planejamento MetropolitanoS/A) epela SEMPLA(SecretariaMunicipal dePlanejamento), a região Noroeste de São Paulo teve o crescimento de sua área urbanizada intensificado a partir dos anos de 1950, se concentrando no distrito de Pirituba e em um pequeno núcleo junto à linha férrea no Jaraguá, que só iniciou sua urbanização a partir dos anos de 1970, impulsionada pela promoção estatal de conjuntos habitacionais. Durante as décadas subsequentes, somando-se a habitações autoconstruídas e a áreas de favelas, tal processo se deu de forma muito rápida, reforçando as desigualdades sociais.
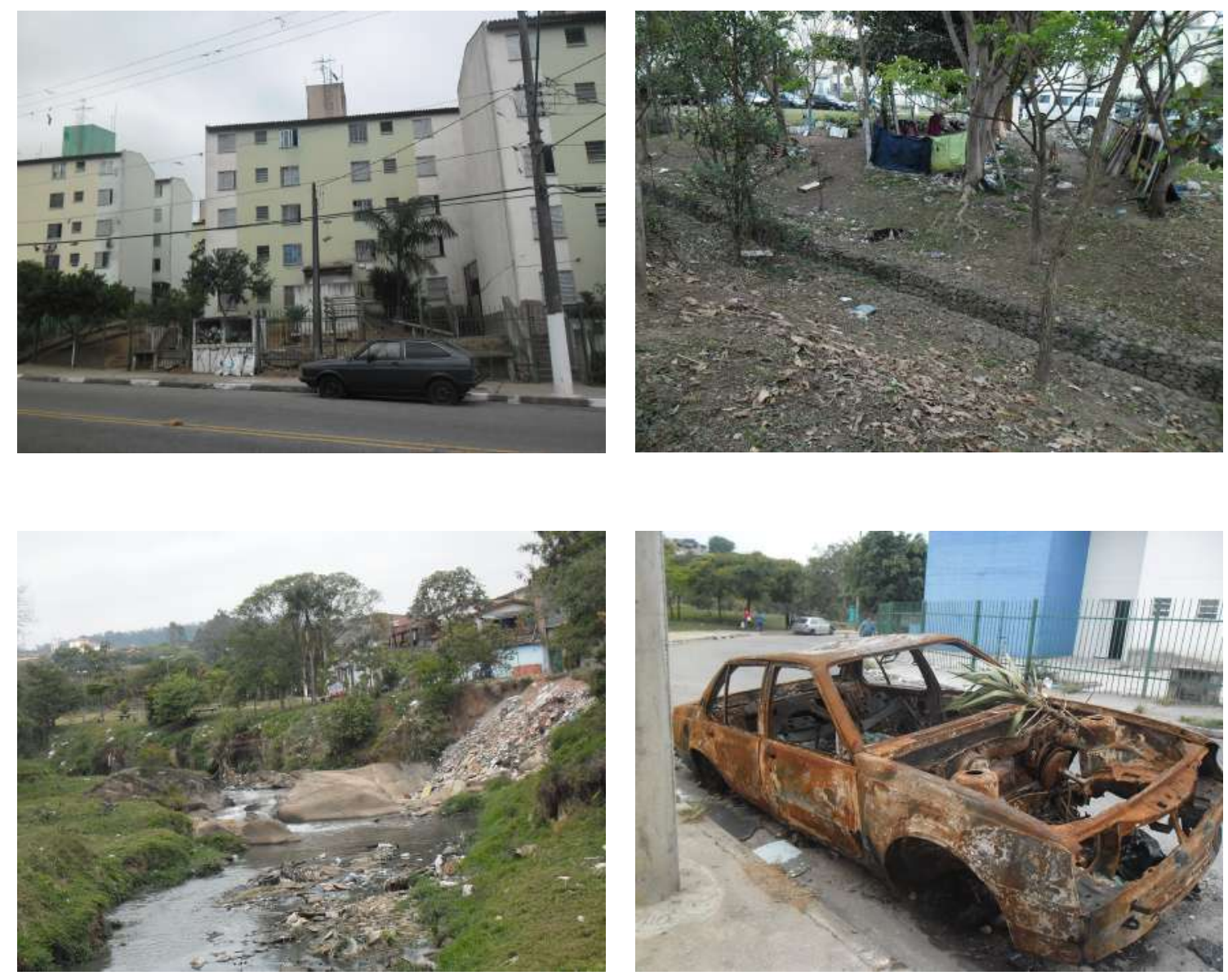
A precariedade tem sido atributo permanente das periferias metropolitanas. A partir dos anos 70 , no momento em que o Estado passa a produzir habitação social adotando a tipologia dos grandes conjuntos, essa situação se agrava, pois os projetos reproduziram as deficiências e carências urbanísticas típicas das regiões periféricas. Em cada uma dessas situações - quer nos espaços produzidos pelo poder público, quer nas resultantes da ação privada - verificam-se processos espoliativos de ocupação das áreas de expansão urbana que resultam em precariedades específicas dos ambientes construídos, legando um tecido urbano desestruturado e carente de atributos de "cidade". Essa precariedade tem duplo registro. Por um lado, está associada ao processo de produção dos espaços residenciais para a população de baixa renda, e por outro à insuficiência crônica de investimentos públicos na escala requerida, sendo ainda reforçada pelo descaso com a qualidade dos espaços construídos. (MEYER, GROSTEIN e BIDERMAN, 2004, p. 51)

Foi a partir de 2008 que a região do Jaraguá começou a receber, de maneira mais intensa,investimentos do mercado imobiliário ${ }^{37}$, resultando na implantação de edifícios verticais e condomínios horizontais residências para o atendimento de uma classe social com maior poder aquisitivo do que aquela, até então, presente no local. Essa nova ocupação territorial favoreceu a implantação de hipermercados, a ocupação de lotes remanescentes com edifícios industriais e, mais recentemente, em abril de 2016, a inauguração do Shopping Cantareira Norte, que passaram a transformar o uso do solo e, consequentemente, gerar uma valorização na região. Diante desse contexto, pode-se dizer que o Jaraguá é uma área ainda em construção, onde a expansão urbana encontra excelentes oportunidades para se difundir, com localização privilegiada junto à importantes vias de acesso, presença de equipamentos urbanos de atração populacional e existência de parques e reservas naturais em seu território e proximidades.

No entanto, cabe ressaltar que a região ainda apresenta índices elevados no tocante à carência e a demanda de infraestrutura nas áreas de educação, assistência social, cultura, esporte e lazer. De acordo com dados fornecidos pela Prefeitura ${ }^{38}$, em 2010, o Jaraguá chegou a ter 39,3\% de sua população sem acesso a áreas públicas de
37 De acordo com dados apresentados pela Secretaria Municipal de Urbanismo e Licenciamento/ SMUL - Departamento de Produção e Análise de Informação/ Deinfo, em 2017, que se utilizou de informações fornecidas pela Empresa Brasileira de Estudos de Patrimônio/ Embraesp. Disponivel em: <http://infocidade prefeitura.sp.gov.br/>. Acesso em 26 jan. 2018.

38 Dados presentes nos Cadernos das Subprefeituras - Material de apoio para Revisão Participativa dos Planos Regionais das Subprefeituras, Subprefeitura Pirituba-Jaraguá, de 2016, e no Plano Diretor Estratégico do Município, de 2014 ambos realizados pela Secretaria $\mathrm{Mu}$ nicipal de Desenvolvimento Urbano da Prefeitura de São Paulo, que se utilizaram de informações do Censo 2010 do IBGE (Instituto Brasileiro de Geografia e Estatística) e levantamentos fornecidos por outras secretarias municipais. Disponivel em: <http://infocidade prefeitura sp.gov.br/>. Acesso em 26 jan. 2018. 
esporte e lazer, e $68,68 \%$ de seus moradores distantes de serviços públicos culturais.

Ainda que o distrito do Jaraguá disponha de equipamentos educacionais, culturais, sociais, esportivos, de saúde, de lazer e áreas verdes, a oferta se mostra insuficiente para o atendimento da região, refletindo nos elevados índices apontados. Vale chamar a atenção também para as características dos serviços oferecidos para as camadas da população de menor renda, que, geralmente, apresentam uma menor diversidade e qualidade quando comparados àqueles disponíveis para as classes de maior poder aquisitivo. Apesar de não abordarmos índices qualitativos, a colocação feita por Lima (1989, p.65), ao se referir aos equipamentos de educação das classes mais pobres, cabe perfeitamente nesse contexto de análise: “(...) malfeitos e malconservados, reforçam a ideia útil para o sistema de que pobre e mal servido é por merecimento."

Ao compararmos a região Noroeste com o restante do Município, principalmente as áreas centrais e o Quadrante Sudoeste, é possível verificar de maneira ainda mais clara a distribuição desigual desses equipamentos pela área urbanizada. As discrepâncias se intensificam apontando para grandes concentrações junto às regiões mais ricas da cidade e o surgimento de áreas com pouca infraestrutura e altas demandas, nos pontos que se distanciam desses setores.

$\mathrm{Na}$ Oficina 02 , em que foram trabalhadas com as crianças a identificação e a localização de pontos de grande interesse urbano no âmbito do Município, o fato descrito anteriormente pôde ser constatado através da construção de um mapa de equipamentos públicos da cidade de São Paulo. Os locais de maior destaque cultural, histórico, esportivo e de locomoção encontram-se distantes da região Noroeste, na qual foram identificados apenas a presença de quatro parques - Pinheirinho d'Água, Anhanguera, Jaraguá e Parque da Parada.

Os mapas a seguir apresentam a distribuição espacial dos equipamentos e serviços públicos pelo Município de São Paulo, reforçando a ideia da segregação urbana apresentada anteriormente, onde a periferia não se situa apenas geograficamente distante do centro físico da cidade, mas se afasta também social, cultural e economicamente das áreas onde se encontram as classes dominantes com grande poder político e econômico. 


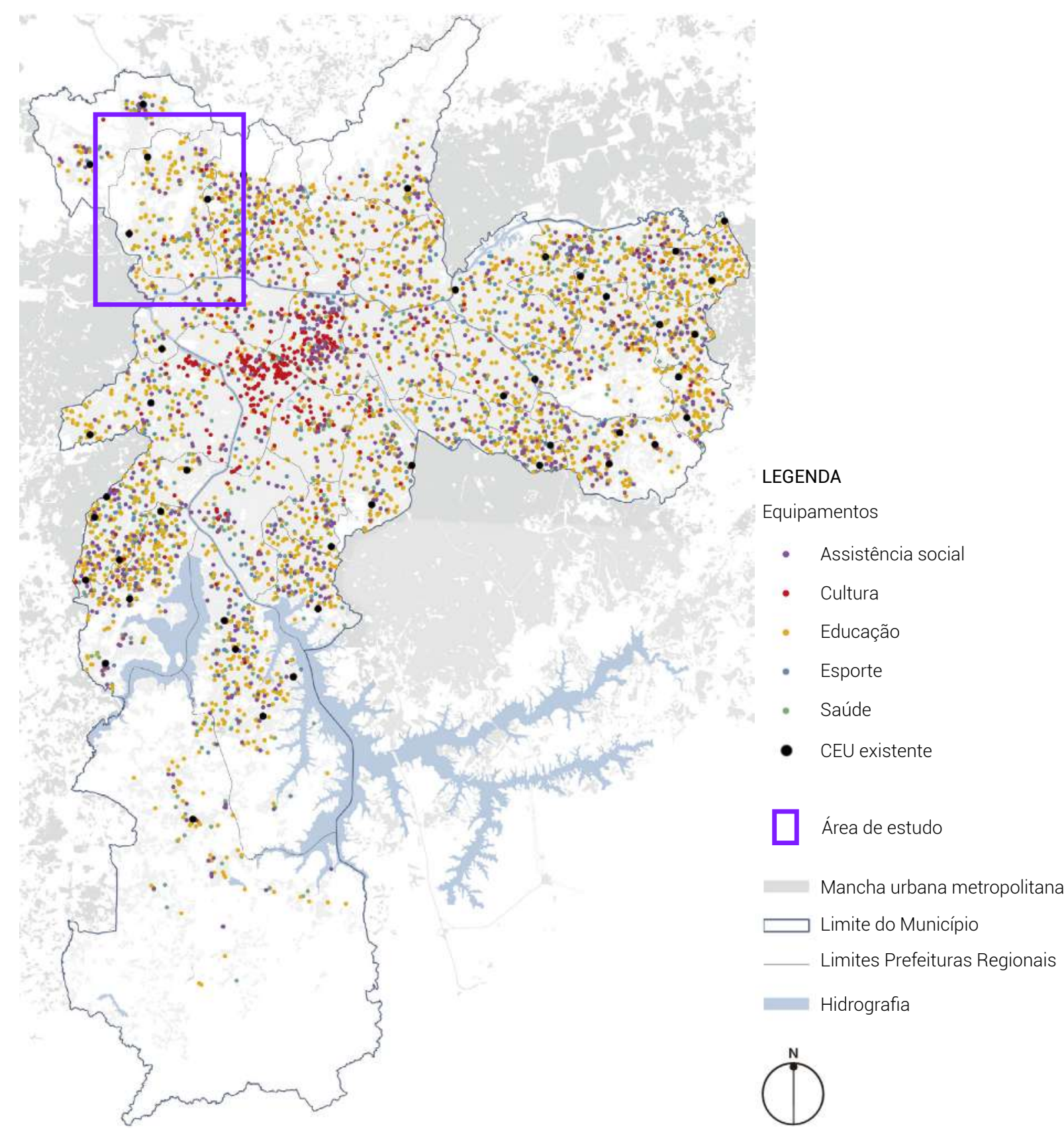

FIGURA 64

Distribuição de equipamentos públicos de assistência social cultura, educação, esporte e saúde.

Fonte: Prefeitura Municipal de São Paulo/ Secretaria de Desenvolvimento Urbano, 2016. 


\section{LEGENDA}

Cobertura de atendimento por equipamentos de cultua

Cobertura de atendimento por equipamentos de esporte

Cobertura de atendimento por parques

- Acessos aos parques

- Equipamentos de cultura

- Equipamentos de esporte

Área de estudo

Mancha urbana metropolitana

\section{$\square$ Limite do Município}

_ Limites Prefeituras Regionais

Parques municipais

Parques estaduais

Distribuição e acesso a parques e equipamentos de esporte e cultu-

Fonte: Prefeitura Municipal de São Paulo/ Secretaria de Desenvolvimento Urbano, 2016.

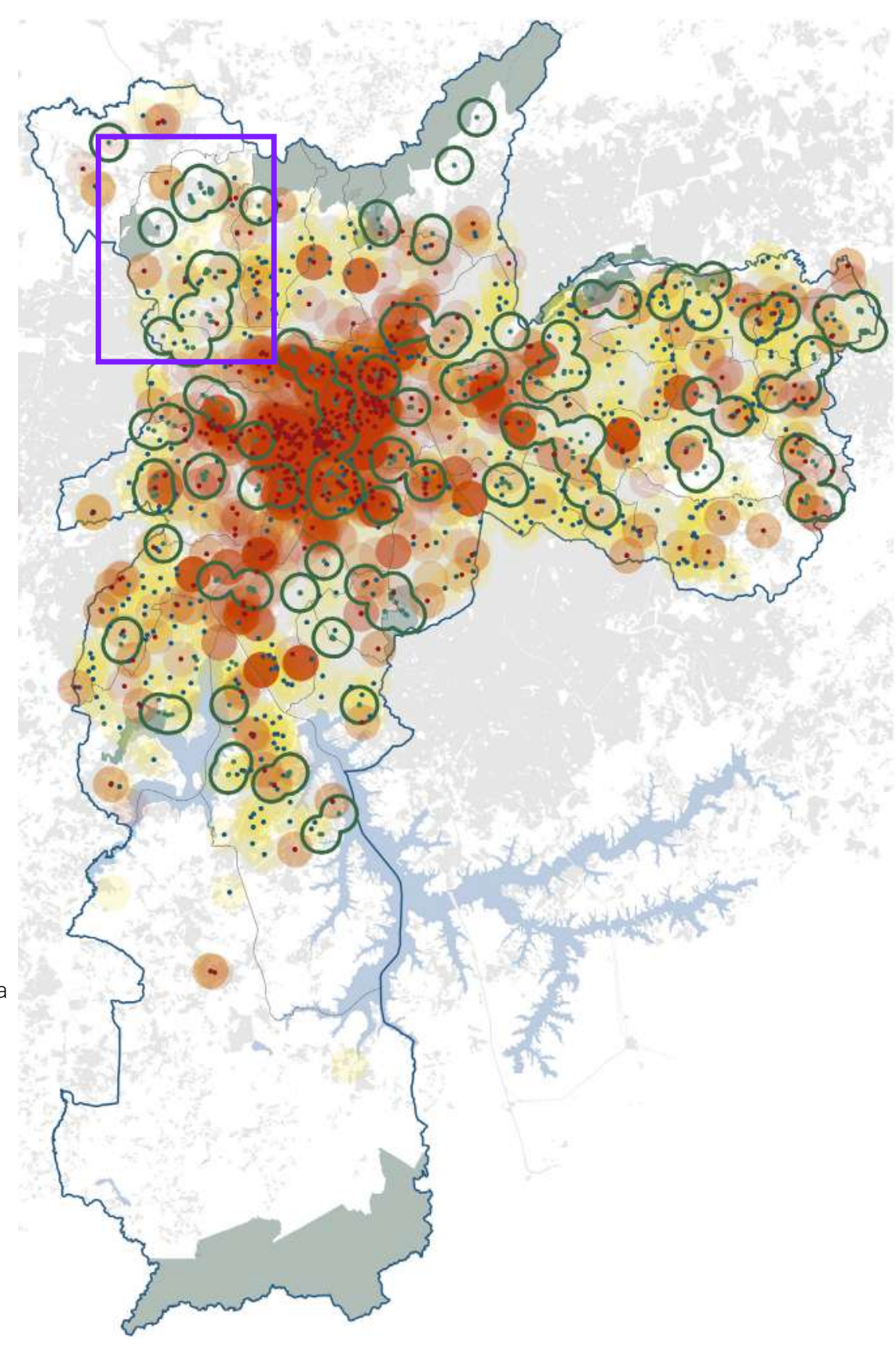


Quando falamos em segregação urbana, a mobilidade se torna um elemento de grande importância e dela decorre também a distribuição dos empregos pelo território, que se relacionam diretamente com os tempos gastos nos deslocamentos casa-trabalho. De modo geral, no Município de São Paulo, observamos que as regiões (Central, Oeste e Quadrante Sudoeste) que possuem grande oferta de empregos por número de habitantes também correspondem àquelas onde seus moradores se deslocam em tempos menores. Já nas áreas periféricas, onde a disponibilidade de empregos é menor, também concentra-se o maior número de habitantes com longos períodos de deslocamento ${ }^{39}$.

O controle do tempo de deslocamento é a força mais poderosa que atua sobre a produção do espaço urbano [...] [e] sobre a distribuição espacial das classes sociais, portanto da infraestrutura, dos equipamentos sociais urbanos e da distribuição dos locais de trabalho, compras, serviços e lazer. Não podendo atuar diretamente sobre o tempo, os homens atuam sobre o espaço, como meio de atuar sobre o tempo. Daí decorre a grande disputa social em torno da produção do espaço urbano e a importância do sistema de transporte como elemento da estrutura urbana. Daí decorre também a segregação, como um mecanismo espacial de controle da distribuição da infraestrutura urbana [...] e do tempo de deslocamento dos habitantes urbanos e, por meio dele, da dominação. (VILLAÇA, 2012, p.288)

Ao observarmos essa questão, notamos uma carência de investimentos voltados ao transporte público no Jaraguá, onde inexistem corredores de ônibus e não há previsão de obras futuras voltadas para esse atendimento ${ }^{40}$. Quanto ao transporte coletivo de massa (trens e metrôs) a região é atendida apenas por uma linha de trem metropolitano, que faz a ligação entre a Estação da Luz, no centro da capital paulista, e o Município de Francisco Morato, na região metropolitana, com duas estações de acesso que possibilitam os deslocamentos dos residentes para áreas vizinhas, centrais e fora do município.

A mobilidade, somada aos demais aspectos apresentados anteriormente - distribuição de empregos, presença e disponibilidade de equipamentos públicos 
voltados para os setores sociais, culturais, educacionais, de lazer e de saúde - influi diretamente na maneira como a cidade é usufruída pelas diferentes camadas sociais. Os moradores de áreas mais equipadas e com grande oferta de infraestrutura têm direito e acesso à cidade de maneira superior àquelas populações que vivem nas margens (e à margem) do município, com restritas possibilidades de acessar os equipamentos distantes de suas moradias, devido às limitações econômicas e sociais que os privam dessas vivências.

[...] nas periferias metropolitanas, raramente há bons equipamentos de saúde, abastecimento, educação, cultura, esporte etc, e, como o transporte é ruim e caro, os moradores, em especial os jovens, vivem o destino do "exílio na periferia", como cunhou Milton Santos (1990) ${ }^{41}$. Nunca é demais lembrar que pobreza e imobilidade é receita para a violência. (MARICATO, 2015, p.45)

Tais considerações e análises foram feitas de maneira ampla, sem distinção das faixas etárias, entendendo que todos os habitantes de uma mesma região - mais equipada e com melhor infraestrutura ou menos equipada e sem infraestrutura - são afetados pelas condições urbanas colocadas pelo território no qual se inserem. No entanto, quando essas questões são focadas diretamente nas crianças moradoras de áreas periféricas, como é o caso dos meninos e meninas do Jaraguá, esses aspectos se potencializam, pois, além de estarem imersos nessa realidade que atinge também aqueles que estão à sua volta, eles são vistos como sujeitos de menor credibilidade, poucos direitos sociais e, muitas vezes, como incapazes de perceberem e transformarem os contextos urbanos nos quais estão inseridos.

O direito à cidade para as crianças não deve ser encarado apenas como a garantia de acesso aos serviços e equipamentos, mas também como uma forma de reconhecimento delas enquanto cidadãs e responsáveis pela transformação urbana.

${ }^{41}$ SANTOS, Milton. Metrópole corporativa fragmentada: o caso de São Paulo. São Paulo: Nobel: Secretaria de Estado da Cultura, 1990 


\section{2 "No fim de semana eu fui no shopping!" - leitura do lazer do consumo e da inserção social}

[fala de uma das meninas participantes das oficinas, relatando o que havia feito no final de semana]

A complexidade de uma cidade como São Paulo, que assume dimensões colocadas no âmbito metropolitano não pode ser encarada apenas em seus espaços livres públicos, que é o foco desse trabalho, mas também nos equipamentos privados, que muitas vezes surgem e consolidam-se como lugares que acolhem os usos coletivos anteriormente realizados nas áreas públicas. Um bom exemplo disso são os shopping centers que assumiram papéis que possibilitam a sociabilidade entre os moradores dos centros urbanos.

Nas atividades propostas para as crianças que participaram das oficinas, o shopping center mostrou-se em diferentes contextos como um espaço bastante comum no cenário paulistano, local de uso corrente voltado ao consumo, ao lazer e também como objeto de desejos. Ganhou destaque em cinco das treze atividades realizadas, como lugar presente no imaginário ou vivido durante visitas cotidianas.

No distrito do Jaraguá, especificamente no bairro Jardim Pirituba, localizado nas proximidades do Parque Pinheirinho d'Água, a cerca de um quilômetro da EMEF Dr. José Kauffmann, em abril de 2016, foi inaugurado o Shopping Cantareira Norte, introduzindo na região um potente equipamento comercial que agrega também outras funções e representações sociais.

Os shopping centers começam a surgir no cenário mundial no momento em que se acreditava que as cidades estavam se tornando inseguras - século XIX (SARLO, 2014). No Brasil, eles ganham destaque a partir dos anos de 1980 e permanecem expandindo sua rede até os dias atuais, agregando características e funções diferentes daquelas para as quais foram originalmente concebidas, voltadas às compras, e ampliando seu atendimento aos novos grupos sociais. 
$\Delta \Delta B \Delta$

\section{MEU FIM DE SEMANA}

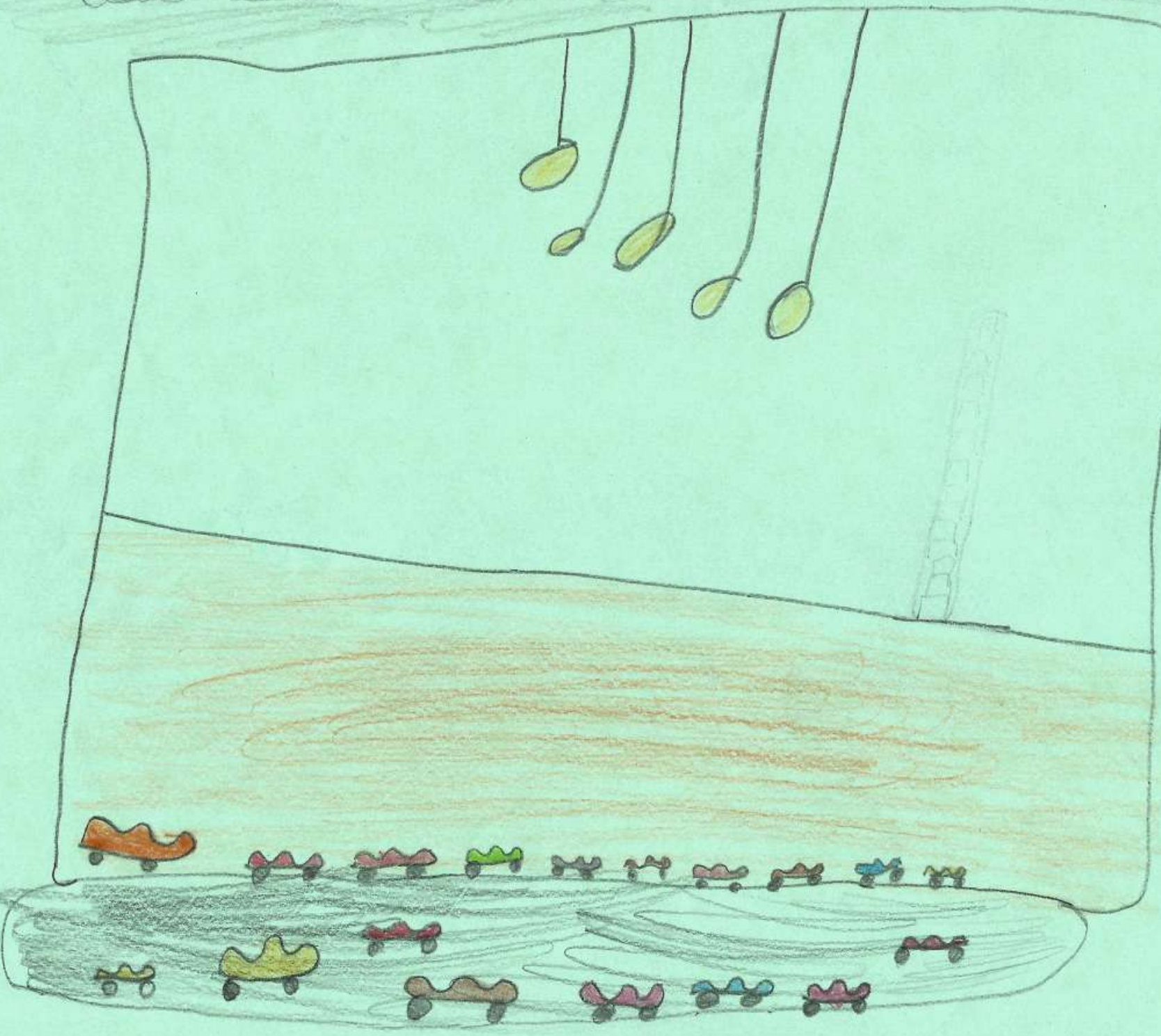

O QUE EU FIZ :

shooring

O QUE EU SENTI:

peliz 
FIGURA 66 [verso]

Desenho elaborado por Lívia. Shopping Cantareira Norte, em resposta ao questionamento sobre 'o que você fez no fim de semana?' Lápis de cor e grafite sobre papel sulfite na cor verde $210 \mathrm{~mm} \times 297 \mathrm{~mm}$, setembro de

2016.

Fonte: Arquivo pessoal, 2016 
Além da função comercial e social para a qual eles se voltam, Pintaudi (1992, p.16) destaca também seu papel na produção do espaço urbano, pois, decorrentes dos investimentos de grandes empresas, "surgem no Brasil no momento em que as condições de desenvolvimento do capitalismo necessitam do monopólio do espaço, para reprodução contínua e ampliada do capital", encontrando aí uma saída para os problemas de sua acumulação, relacionando-a à produção da cidade.

A inserção desses equipamentos no tecido urbano aponta para uma organização espacial cada vez mais voltada ao atendimento dos interesses de uma gerência e do monopólio das classes econômicas dominantes, com poder decisório sobre a cidade. Esses empreendimentos são capazes de gerar uma transformação revolucionária nas relações territoriais, alterando redes de infraestruturas de transporte e circulação viária, bem como enfraquecendo e redefinindo as relações entre os comércios existentes. Somadas a essas alterações, associam-se mudanças nas áreas residenciais, que tendem a valorizar-se e verticalizar-se nas proximidades desses centros comerciais, além da implantação, em determinados casos, de centros empresariais que também colaboram para o processo de valorização diferencial da cidade. (GAETA, 1992)

A construção do espaço urbano, determinada pelos investimentos e não mais pelas necessidades do mercado, utiliza-se da valorização diferencial, da sua ideologização, para a sua própria dinâmica de expansão. 0 elemento superestrutural ganha significado novo nessa fase, em função do contorno às contradições do desenvolvimento capitalista, etorna-sea chavena formação do espaço sistematicamente ideologizado. (GAETA, 1992, p.59)

As localizações dos shoppings são estratégicas, buscando atingir um número máximo de frequentadores, mesmo que para isso precisem investir em infraestrutura de adequação externa, como é o caso do remanejamento do sistema viário para atender a nova demanda gerada pelo aumento da circulação de automóveis ou para aproximar regiões, até então distantes, que não teriam acesso a esse local. Porém, a implantação desses equipamentos "independem da existência de uma tradição comercial na área em que se instalam porque criam o ambiente por inteiro." (PINTAUDI, 1992, p.32), 
com todos os seus símbolos: ruas comerciais com lojas de diferentes segmentos, praças de alimentação e lazer e alamedas que abrigam grande parte da rede de serviços existentes no espaço urbano. São espécies de cidades dentro das cidades, se colocando em contraposição à deficiência de infraestrutura que ela apresenta, criando locais confinados, com climatização artificial e sensação de que o tempo não passa. (FRÚGOLI JR., 1992)

"O shopping não é simplesmente uma parte da cidade, mas uma substituição por um sistema novo, em que se atenua ou desaparece o que, no passado, caracterizou o urbano." (SARLO, 2014, p.11) Ele pode estar inserido em qualquer localidade, pois não depende diretamente das relações com o seu entorno para existir e se manter, diferentemente das galerias de rua que necessitam da interação com a cidade e pressupõem espaços contíguos em seus arredores para facilitar o acesso de seus frequentadores. No entanto, quanto mais popular for o seu público alvo, mais acessível ele deve ser, a fim de garantir a atração de mais frequentadores, mesmo que para isso tenham que utilizar de artifícios que ampliem seus acessos. O Shopping Cantareira Norte, por exemplo, oferece uma linha de transporte gratuito saindo da Estação Jaraguá da CPTM e faz quatro paradas em seu percurso, para que outros usuários possam embarcar com destino ao centro comercial.

A expansão da rede desses equipamentos no tecido urbano, pulverizando, praticamente todas as regiões das grandes cidades, e a disseminação do uso do automóvel colocam em questão o papel e a importância das áreas centrais, que vão, aos poucos, perdendo suas funções tradicionais de encontro, socialização e lazer, transformando-se em locais de passagem e entrando em processos de saturação e deterioração.

Além desses aspectos relacionados com a localização e a produção do espaço urbano, é de interesse dessa pesquisa entender as imagens e funções que os shopping centers assumem junto às crianças; para isso, faz-se necessário a compreensão dos papéis que eles representam socialmente. 
O shopping center pode ser visto sob diferentes óticas, como: local voltado ao consumo; espaço de lazer e sociabilidade; ponto de encontro para a construção de identidades e formação cultural urbana, sobretudo entre os jovens; lugar para olhar e desejar algo; ambiente de possibilidades ilusórias de inserção em camadas sociais mais altas, já que o acesso às mercadorias é permitido e facilitado, ainda que visualmente, e espaço de diversidade social e cultural, que possibilita também a distinção social, a discriminação e a segregação, em oposição às áreas públicas que se apresentam mais democraticamente.

Para as crianças, além da exposição às mercadorias e da sociabilidade que esses centros comerciais permitem, a brincadeira também assume outras características quando muitos equipamentos voltados para essa demanda são oferecidos, tais como: brinquedos e jogos eletrônicos semelhantes aos encontrados nos parques de diversões, áreas especializadas no atendimento infantil (os chamados 'espaço criança'), locação de carrinhos que tornam a visita ao local mais divertida e lúdica, além da grande exposição às mercadorias (brinquedos, roupas, calçados, acessórios e alimentação) voltadas exclusivamente para esse público consumidor.

Ao surgir a figura do shopping na fala das crianças que participaram das oficinas, podemos entendê-lo dentro dos vários aspectos apontados, tendo como de maiores destaques aqueles que se relacionam com os aspectos do lazer e do consumo, além do imaginário social e cultural que eles representam.

Nesse sentido, pode-se dizer que

o shopping center realmente está deixando de ser apenas um centro de compras, para se tornar um local simbólico, de socialização e integração dos indivíduos, um retrato da sociedade sem seus problemas urbanos, enfim, uma 'utopia social' buscada pelos indivíduos da sociedade vigente. (WYPYCH,2011, p.149)

A partir disso, alguns pontos surgem como possíveis responsáveis pela grande atratividade que esses equipamentos imprimem junto às crianças, tais como: existência de brinquedos e áreas voltadas ao lazer; segurança e, consequentemente, 
maior liberdade em oposição aos demais espaços urbanos; possibilidades de compras, ainda que de pequenos objetos; locais de fantasia e imaginação, com decorações e atividades especializadas durante datas comemorativas.

A questão da segurança se torna um ponto crucial para o surgimento dos shopping centers e uma das principais buscas de seus frequentadores. Caracterizado pela negação dos espaços livres públicos, esses centros comerciais se constituem como áreas de gestão e propriedade privadas, mas de apropriação e usos coletivos e públicos. Por se estabelecerem dentro de normas que garantem o afastamento dos 'indesejados' e dos 'irregulares', possibilitam e atraem famílias, jovens e idosos que buscam essa sensação de tranquilidade, onde

a regularidade, a ordem, a limpeza e a repetição, que impedem o salto ao imprevisto, garantem que o shopping funcione sem nenhum dos inconvenientes do urbano. Em um momento em que a cidade é vista como fonte de males e em que se pede uma cidade disciplinada que responda a esse imaginário do medo e a condições reais de incerteza, o shopping oferece o que se busca e, além do mais, de graça. (SARLO, 2014, p.15)

Acredita-se que a segurança seja um aspecto muito importante para o uso tão desejado desses lugares pelas crianças, pois quando estão nesses locais, acompanhadas por seus pais, podem agir com uma liberdade que não lhes é permitida nos espaços livres públicos. A isso, soma-se também a imagem e o estabelecimento de um ambiente artificialmente construído, que possibilita novas experiências e criações de brincadeiras, fora do previsto pela ordem e dinâmica de funcionamento desses locais e em oposição aquilo que é feito na cidade.

O brincar para a criança é uma forma de expressar-se no mundo e de interpretálo em suas práticas sociais, através daquilo observado na mídia, nos ambientes familiares e de usos coletivos (NASCIMENTO, 2009). Dessa forma, o shopping surge como um lugar em que a cultura infantil também assume suas características, tomadas pela dinâmica e pela criação imagética e artificial que esse cenário fornece, em contraposição aos espaços urbanos. 
Em oposição ao uso lúdico dado pelas crianças, o projeto e o funcionamento desses centros comerciais refutam o caráter imprevisível e incontrolável da cidade, que possibilita uma exploração muito mais dinâmica, com experiências corporais e intelectuais que extrapolam as regras e inserem-se diretamente no contexto urbano, com características e peculiaridades específicas dentro de cada realidade. Os shoppings, por se constituírem dentro de uma linguagem universal, não são planejados para possibilitar o imprevisto ou a surpresa; seu objetivo é ser o mais funcional possível, permitindo que os acessos e os passeios por seus corredores não sejam dificultados nem atrapalhem a sua dinâmica de funcionamento, lógicas que podem ser subvertidas dentro da apropriação desses locais pelos meninos e meninas.

"O shopping transformou-se na praça pública que corresponde à época, e em quase todos os lugares inclui cinema, restaurantes e lojas, parques de diversão cobertos, galerias de exposição, salas de conferências" (SARLO, 2014, p.9). Ele busca recriar, a seu modo, as funções também oferecidas nas áreas urbanas; porém, estipulando suas regras de utilização, padrões de ordem, controle, segurança e consumo, negando a cidade como um local possível de se conviver. Essa imagem perpassa de maneira ampla pelo o imaginário de muitos cidadãos, desde as crianças até os jovens, adultos e idosos, favorecendo, cada vez mais, a sua utilização.

Dessa forma, esses equipamentos, que surgem voltados para atender as necessidades de consumo de uma classe de médio e alto poder aquisitivo, transformam -se e adquirem uma nova importância voltada à sociabilização e ao lazer. Atualmente, na maioria dos estabelecimentos, quase metade de suas áreas são destinadas a essa função, incluindo aí as praças de alimentação e os espaços para abrigar o footing que as cidades grandes não comportam mais.

Os shopping centers assumem, de maneira ainda mais marcante, o papel de lazer entre as camadas mais populares, pois elas possuem menos oportunidades de diversão do que as classes altas e médias (ROSSARI, 1992). Desse modo, quando um equipamento desse porte se instala em áreas carentes de infraestrutura de cultura $\mathrm{e}$ 
de lazer, como é o caso da região do Jaraguá, ele se torna uma importante opção de divertimento entre os jovens, os adultos e as crianças, que passam a frequentá-lo mais intensamente para satisfazer suas demandas não supridas pelos espaços públicos - socialização, encontros, passeios e entretenimento - do que efetivamente para as compras.

Em tensão com as clivagens sociais e as impossibilidades econômicas, nos países periféricos o shopping revela uma desigualdade maior entre os que o usam como passeio e os que, além disso, compram significativamente. No entanto, o êxito para uns e outros está nas possibilidades de sonho oferecidas: sempre é melhor desejar do que não desejar. (SARLO, 2014, p.12)

O desejo também é um fator muito importante para as crianças, sobretudo aquelas das classes mais populares, que veem nesses centros comerciais uma possibilidade de alimentar seus sonhos.

Ainda que, dentre os meninos e meninas participantes desse trabalho, não foi observada a exclusão dos espaços livres públicos para as práticas ligadas ao lazer, 0 shopping center surgiu como uma alternativa onde essas atividades podem ocorrer. Acredita-se que, dentre as camadas mais populares, em momentos em que os usos dos locais públicos abertos tornam-se dificultados (dias chuvosos ou muito frio), esses equipamentos transformam-se em uma das únicas alternativas de lazer gratuito.

Nos shopping centers mais populares seus espaços ganham o status de 'praças intrabairros', reunindo muitos jovens, principalmente, nas noites de sextas-feiras e aos finais de semana, em busca de sociabilização e consumo de mercadorias de baixos valores. (FRÚGOLI JR., 1992) 

"Gosto de brincar nos brinquedos do Shopping Cantareira quando minha mãe me leva." (Débora)

FIGURA 67 [verso]

Desenho elaborado por Débora. Shopping Cantareira Norte, em resposta ao questionamento sobre 'qual brincadeira você mais gosta?' Lápis de cor e grafite sobre papel sulfite na cor marfim $210 \mathrm{~mm}$ × 297mm, outubro de 2016

Fonte: Arquivo pessoal, 2016 


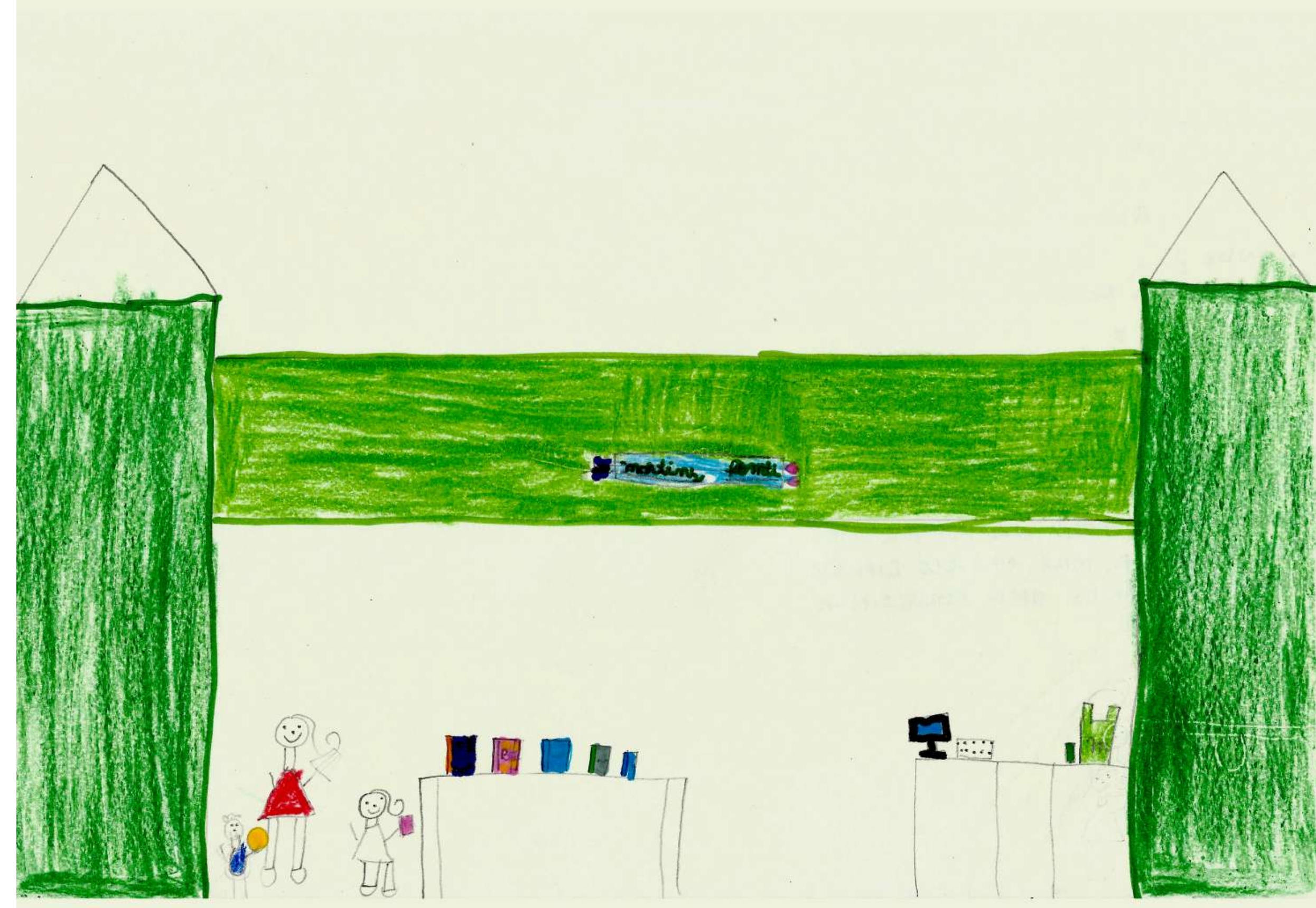


"Desenhei quando eu fui na livraria do shopping com a minha mãe e ela comprou um livro que eu queria e uma bola para o meu irmão." (Bárbara)

\section{FIGURA 68 [verso]}

Desenho elaborado por Bárbara. Livraria do Shopping Cantareira Norte, em resposta ao questionamento sobre 'qual brincadeira você mais gosta?' Lápis de cor e grafite sobre papel sulfite na cor marfim $210 \mathrm{~mm}$ x $297 \mathrm{~mm}$, outubro de 2016.

Fonte: Arquivo pessoal, 2016. 
Recentemente, os 'rolezinhos'42, encontros em shopping centers promovidos por jovens moradores de áreas periféricas da capital paulista, ganharam destaque na mídia e entre os frequentadores desses estabelecimentos. Esses eventos, organizados através das redes sociais, como o Facebook, reuniram milhares de adolescentes com a intenção de ocupar os espaços internos desses equipamentos comerciais e expor uma situação de grande carência e demanda por espaços de lazer e diversão nas periferias. Inicialmente, os 'rolezinhos' não surgem como uma forma de manifestação política, mas apresentam um caráter político ao ocupar massivamente os shopping centers para a sociabilização entre os jovens desprivilegiados das áreas periféricas, que questionam e denunciam a forma desigual de produção do espaço urbano.

Nessa mesma temática, Frúgoli Jr. (1992, p.78) já identificava no início da década de 1990 que

esse uso marcado pela diversidade implica um cruzamento de significações, a começar pela própria concepção de lazer. Do ponto de vista administrativo, o lazer nos shopping centers deve servir como atrativo para o consumo de mercadorias e serviços, para garantir a permanência prolongada e gerar 'tráfego' nos corredores, mas nunca como um fim em si mesmo. Mas para os frequentadores, nem sempre o lazer é tão 'instrumental': referimo-nos ao lazer que muitas vezes transcende ao consumo (ou que guarda com esse uma relação apenas ocasional) e também a usos do espaço que implicam sobretudo a busca de relações com o outro, a criação de laços superficiais ou duradouros, enfim, um lazer que se traduza na busca de sociabilidade.

42 Os 'rolezinhos' foram iniciados no fim do ano de 2013 e ganharam grande destaque em 2014. Os encontros reuniam centenas de adolescentes com a intenção de se divertir dentro dos shoppings. Essas manifestações, geralmente, acabavam com a chegada da Polícia Militar e o fechamento dos estabelecimentos, que nem sempre aconteciam de maneira pacífica. 
sociedade: uma 'cidade ideal', repleta apenas de cidadãos consumidores, sem vestígios de pobreza e deterioração", mas, ainda adverte, "jamais poderão resgatar plenamente o dinamismo das ruas e praças: vivas, imprevisíveis, heterogêneas e realmente públicas". (FRÚGOLI JR., 1992, p.92)

Além das funções e representações de uma utopia urbana que esses espaços criam, estabelecem-se dentro de uma imagem ilusória de um lugar acolhedor e democrático para todos, colocando as mercadorias acessíveis aos olhos, atraindo diferentes faixas etárias e buscando atender também as demandas de lazer. No entanto, tudo isso se faz através de um rigoroso sistema de controle, ordenação e afastamento das características indesejadas da cidade, buscando criar a imagem de uma

Terra do Nunca de jovens em que circulam pessoas de todas as idades, uma fantasia pueril da abundância que parece ao alcance da mão porque está ao alcance da vista. É uma festa óptica e extensiva à sociedade. [...] sobretudo por que o shopping não os expõe a uma humilhante retirada com as mãos vazias, já que foram simplesmente olhar. (SARLO, 2014, p.26)

Nesse sentido, pensar no papel do consumo dentro desses estabelecimentos comerciais implica na reflexão sobre o projeto de cidade e sociedade que almejamos; o que para Frúgoli Jr. (1992, p.92), talvez "não esteja propriamente numa 'cidade ideal intramuros', mas numa instituição que se integre de forma mais permeável à cidade real, onde a esfera do consumo esteja mais relacionada com a esfera da cidadania." 


\section{3 "Aqui não vai ter mais brinquedos?" - leitura dos espaços das infâncias urbanas}

[fala de um dos meninos participantes das oficinas, durante visita ao entorno da escola, quando observada a colocação de tapumes para construção do CEU Pinheirinho d'Água em área coincidente com os espaços de estar, quadras esportivas e brinquedos do Parque Linear do Córrego do Fogo]

A necessidade de equipamentos voltados para atender as demandas das crianças, principalmente aquelas relacionadas ao lazer e à brincadeira, ou a adequação da cidade para acolher as atividades infantis em seus espaços públicos apareceram, de maneira unânime, como resposta às atividades propostas nas oficinas realizadas com os meninos e meninas. Tais lugares surgem por meio de seus usos cotidianos, desejos de melhorias, reparos e equipamentos novos, inexistentes em seus bairros.

Ao colocar em discussão os elementos de atendimento às necessidades apresentadas pelas crianças - parquinhos, parque de diversão, campos de futebol... - não se deseja pensar apenas nos locais especializados para essa faixa etária, mas também em lugares capazes de acolher esses usos e os demais cidadãos de modo não discriminatório. Desse modo, a criação de áreas multifuncionais se apresenta como uma alternativa atrativa, possibilitando a interação das crianças em processos sociais com os adultos, ao mesmo tempo em que fortalece a posição política da cidade na construção de espaços que não negam a infância.

Os espaços públicos urbanos, quando não têm uma atenção especial com a questão da infância, podem ser locais de subordinação ao poder daqueles que efetivamente o constroem. "O poder, primeiro, da sociedade de classes, segundo, das instituições representativas dessa sociedade e, terceiro, dos adultos em geral, se apodera do espaço da criança e o transforma num instrumento de dominação." (LIMA, 1989, p.10) Essa visão, com o excessivo controle e organização, compromete a liberdade dos meninos e meninas nas áreas de uso público, onde são, muitas vezes, cerceados de suas formas de expressão por receio de insegurança imposto pelos mais velhos. 
A ideia de superioridade e dominação dos adultos sobre as crianças reflete-se também no modo da produção urbana, seja através dos lugares voltados exclusivamente para atendimento das demandas infantis, que não contam com a participação de seus usuários, seja nas áreas de uso comum a todos os cidadãos que, muitas vezes, são construídas e caracterizadas para reforçar essa visão autoritária. "Logo, o espaço também é um instrumento de poder." (LIMA, 1989, p.37)

Além do adultocentrismo existente nas relações sociais na produção da cidade, o Estado e as políticas públicas por ele determinadas também assumem papéis de grandes controladores e definidores do futuro das crianças, sobretudo aquelas pertencentes às camadas mais populares.

[...] é o Estado que decide qual o nível de saúde que a criança pode alcançar ou o tipo de educação que melhor lhe convém, não por e para ela, mas em função dos interesses do capital, seja para fazê-la cidadão disciplinada e obediente útil para as empresas, seja para o Estado.

Assim, o futuro das crianças não é determinado nem pela sua vontade nem mesmo pela de seus pais, mas pela vontade de um Estado que representa os interesses hegemônicos da sociedade. (LIMA, 1989, p.34)

As políticas voltadas aos espaços públicos pensados e planejados para o atendimento das demandas apresentadas pelos bairros localizados nas periferias urbanas, como é o caso do Jaraguá, são ainda mais desrespeitosas em relação à infância, pois não consideram essas crianças como sujeitos de direitos, mas como "parte da sucata industrial que se aproveita ou não na produção futura, desde que ela não se oxide enquanto cresce. Se isso acontecer, ela deixa de ser criança e passa à categoria de menor, objeto mais insignificante do que criança" (LIMA, 1989, p.38). Se a temática da infância urbana quase não tem abertura dentro das discussões e das transformações das áreas centrais, quando olhamos para os lugares mais desfavorecidos econômica e socialmente, localizados nas periferias, essas questões ganham dimensões ainda mais excludentes, já que é no espaço físico que as desigualdades ganham materialidade e 
transparecem. Nesse sentido,

o território [é] demarcado pelo poder em todos os sentidos. Não é por acaso que a distribuição das habitações, dos serviços e dos equipamentos ocorre desigualmente na cidade, em sociedades desiguais, assim como não surpreende a demarcação virtual do espaço, do centro para a periferia, do grupo dos maiores para o grupo dos menores [...]

Como ficam então os espaços de brincar das crianças dominadas pelo poder econômico e, dentre elas, aquelas que pertencem às camadas menos poderosas da sociedade? (LIMA, 1995, p.187)

No Jaraguá, durante a oficina em que as crianças saíram a campo para registrar fotograficamente o entorno da escola, identificando aspectos positivos e negativos, ficou nítido o descaso das condições e da produção dos espaços com a questão da infância: lixo ocupando áreas de lazer e circulação; automóveis, motocicletas e construções de edifícios apropriando-se de locais com equipamentos destinados às crianças.

Segundo Matthews (199543 apud TONUCCI, 2005, p.201) "a visão da paisagem urbana por parte dos planejadores e dos arquitetos reflete a percepção dominante de uma sociedade, de modo que os grupos já 'no limite' são ainda mais marginalizados pelas políticas de território."

"Nas nossas cidades, carros privatizam as ruas, praças tornam-se inseguras, casas diminuem de tamanho e as áreas destinadas ao lazer das crianças nos prédios de apartamentos encolhem-se nos retalhos úmidos e sombreados dos lotes." (LIMA, 1995, p. 190)

Antes que o automóvel assumisse o protagonismo no cenário urbano, as

${ }^{43}$ MATTHEWS, M. H. Living on the edge: children as 'outsiders'. Tijdschrift voor Economische em Sociale Geografie, LXXXVI, p.456-466, 1995 . 
como podem ser vistos nas descrições de Ariès (2006), Farge ${ }^{44}$ (1976 apud LIMA, 1989) e Lima (1995), esses momentos de interações eram importantes para as trocas e os aprendizados sociais.

Hoje, em oposição a essas cenas que se tornam raras nos grandes centros urbanos, como é o caso de São Paulo, vemos, cada vez mais, os automóveis apropriando-se de espaços anteriormente destinados e ocupados pelos adultos e crianças, transformando-os em locais de passagem. Com raras exceções, em algumas áreas mais distantes das regiões centrais ou em dias atípicos - finais de semana, feriados ou ainda durante passeios escolares - é possível notar a presença das crianças nos espaços e equipamentos públicos, ainda causando alguma surpresa ou estranhamento.

Parece que hoje, em uma cidade ocidental, os automóveis parados ou em movimento cobrem e, portanto, privatizam a grande maioria da superfície pública formada pelas ruas e pelas praças. Por outro lado, resulta que nos países ocidentais o número de automóveis em relação à população pode ser estimado em torno de 50 automóveis para cada 100 habitantes e que a metade desses carros fica parada. Precisamos, portanto, pensar que um percentual de $25 \%$ da população condiciona a vida dos outros $75 \%$, limitando sua mobilidade, privando-os de espaço, negando-Ihes a segurança. (TONUCCI, 2005, p.50)

Apesar desses dados terem sido levantados dentro de uma realidade europeia, São Paulo compartilha de semelhante situação. Segundo informações do Departamento Estadual de Trânsito (Detran/SP), em setembro de 2017 a cidade contava com 6.025.302 automóveis ${ }^{45}$, enquanto estimativas do Instituto Brasileiro de Geografia e Estatística (IBGE) previam que a população paulistana atingiria o número de 12.106.920 habitantes ${ }^{46}$, no mesmo período.

O excessivo número de veículos automotivos nas ruas é reflexo da ampliação gradativa do desejo de meios de transporte individuais por parte dos adultos, o que, consequentemente, implica na redução da mobilidade e da autonomia das crianças nas áreas urbanas, já que os veículos são grandes responsáveis pelo aumento dos riscos de acidentes nesses locais.

\footnotetext{
${ }^{44}$ FARGE, Arlette. Vivredans la rue. Texto apresentado na Conferência Informations Sociales Transmises par les Objects. Helsinki, abr. 1976

45 Dados retirados de: DEPARTAMENTO ESTADUAL DE TRÂNSITO. Disponível em: <https://www.detran.sp.gov.br/ wps/wcm/connect/portaldetran/detran/ detran/estatisticastransito> Acesso em: 18 de jan. 2018

${ }^{46}$ Dados retirados de: INSTITUTO BRASILEIRO DE GEOGRAFIA E ESTATÍSTICA. Disponível em: <https://cidades.ibge. gov.br/brasil/sp/sao-paulo/panorama Acesso em: 18 de jan. 2018.
} 


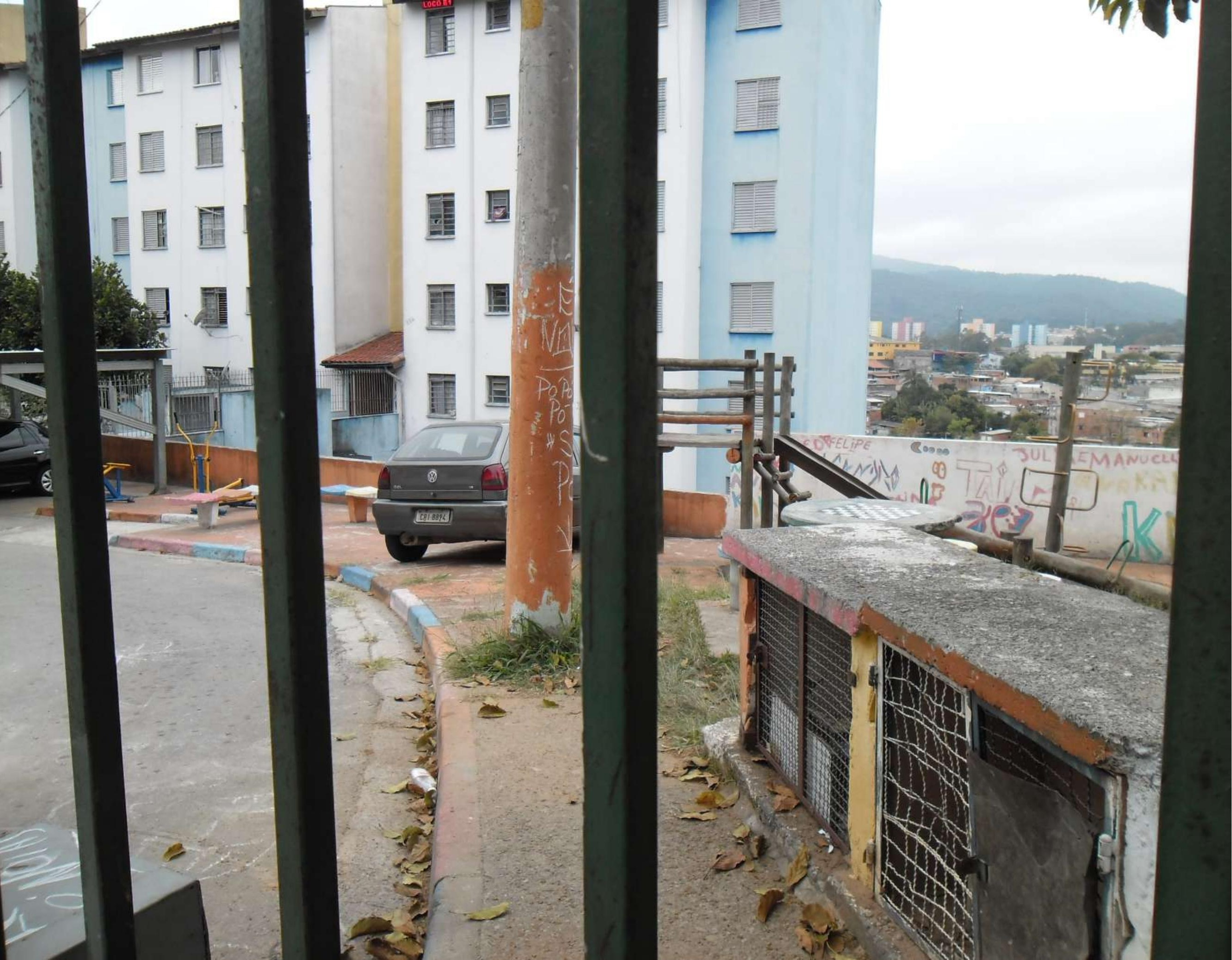


FIGURA 69 [verso]

Fotografia feita pelo grupo de Danilo e Gabriel durante visita ao entorno da escola. Brinquedos, equipamentos de ginástica e área de convivência delegados aos remanescentes do terreno e disputando lugar com estacionamento de automóveis. Máquina fotográfica digital, setembro de 2016

Fonte: Arquivo pessoal, 2016. 


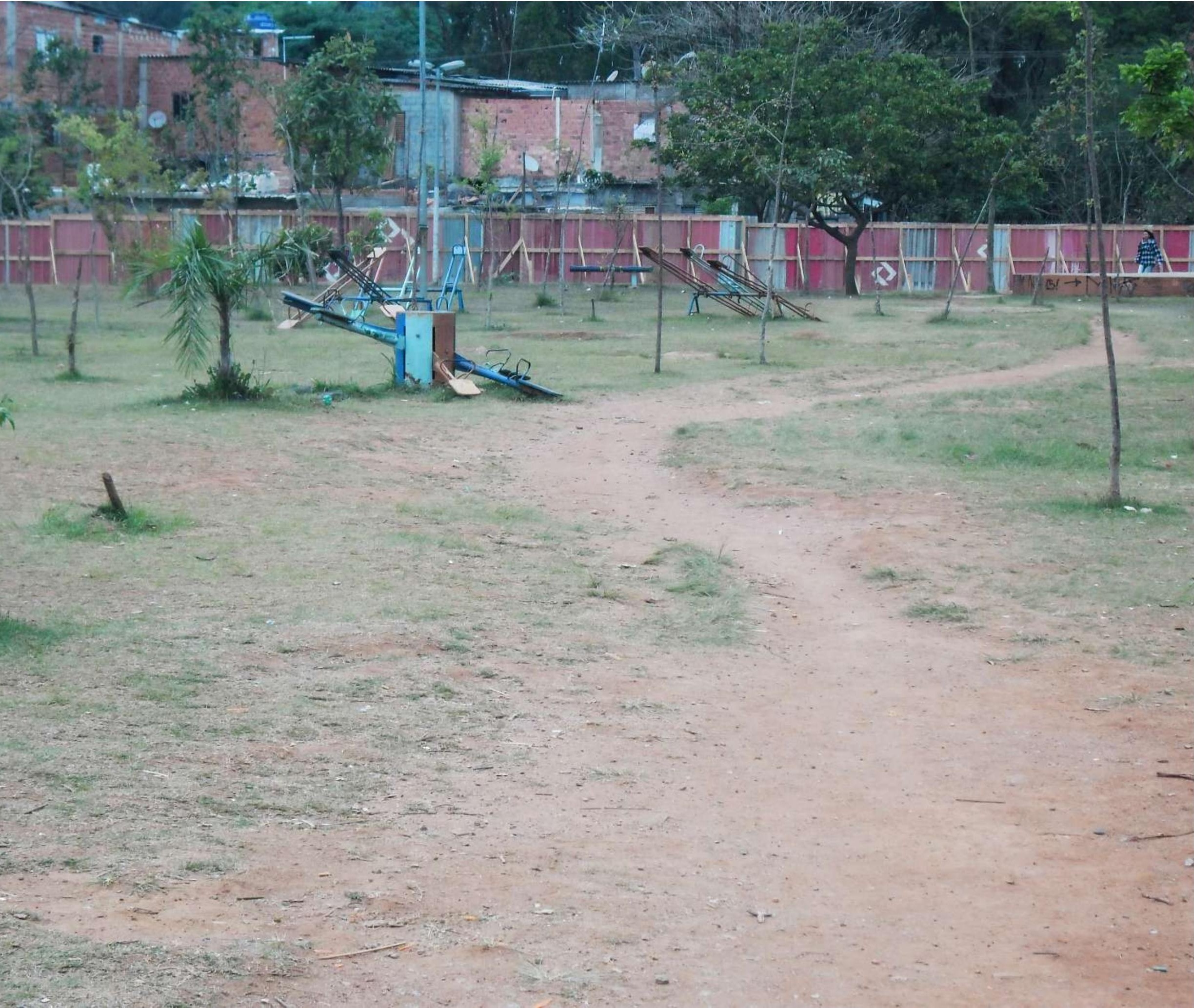




\section{FIGURA 70 [verso]}

Fotografia feita pelo grupo de Gustavo e Izabela durante visita ao entorno da escola. Área com brinquedos no Parque Linear do Córrego do Fogo sendo fechada, com colocação de tapumes, para implantação do edifício do CEU Pinheirinho d'Água. Máquina fotográfica digital, setembro de 2016.

Fonte: Arquivo pessoal, 2016 
Além da questão da insegurança relacionada à presença marcante dos automóveis, a temática ligada à violência, como assunto recorrente nos cenários urbanos brasileiros, também aparece como um dos fatores determinantes para a redução da presença de crianças nos espaços públicos, principalmente quando estão desacompanhadas de adultos.

A segurança, ou a falta dela, ganhou destaque muito grande no discurso das mães dos meninos e meninas participantes dessa pesquisa. Em mais de $80 \%$ dos relatos, essa temática surgiu como um dos fatores que impedem que seus filhos usufruam dos espaços urbanos. No entanto, a percepção infantil sobre esse mesmo assunto apresentou-se de maneira muito distinta, quase não aparecendo em suas falas, representações e atitudes; elas praticamente não demonstraram medos ou receios de estarem nas áreas públicas. Para Tonucci (2005), os adultos carregam uma imagem urbana muito mais tomada pelas fatalidades e pelos aspectos negativos, enquanto as crianças têm uma percepção do risco e do perigo muito diferentes, o que reflete em atitudes e proposições de soluções também distintas. Ao mesmo tempo em que os adultos respondem a esses eventos retirando as crianças das ruas, elas apontam para que se modifiquem as condições ambientais a fim de garantir sua presença nesses locais.

A diminuição dos espaços públicos somada a redução da mobilidade e da autonomia infantil, em decorrência do aumento de automóveis e de situações de violência urbana, interferem diretamente no

desenvolvimento e [no] aprendizado do viver coletivo, da partilha, da solidariedade, das regras traçadas em comum, justamente numa época histórica em que o crescimento demográfico, as crises econômicosociais e a pluralidade cultural exigem de cada um, a capacidade de saber-se ser humano, isto é, inserido e de atos responsáveis, tanto dos coletivos próximos quanto de uma comunidade internacional. (LIMA, 1995, p.190)

Dessa forma, podemos entender a cidade não apenas como suporte físico onde se realizam as ações, mas também como elemento fundamental para o desenvolvimento, 
as construções e as relações humanas. Sendo assim, quando pensamos nas infâncias urbanas não devemos aspirar por espaços especializados e exclusivos para atender as necessidades das crianças, pois esses locais seriam pobres em oportunidades de trocas e aprendizados, limitando conhecimentos e habilidades adquiridos por meio da observação e da imitação da vida adulta nas brincadeiras, tornando-os previsíveis em suas possibilidades de criação e de fantasia infantil.

Sentir a necessidade de projetar espaços dedicados exclusivamente às crianças significa que todos os espaços públicos são considerados inadequados e, portanto, proibidos para elas. Obrigar-se a não fazer isso significa enfrentar o problema, muito mais rico de um ponto de vista urbanístico e social: como os espaços públicos, que representam a parte mais significativa da cidade, podem acolher também as crianças juntamente com todas as demais categorias sociais? Os espaços serão públicos se forem acessíveis a todos, sem barreiras arquitetônicas, passíveis de serem alcançados através de percursos seguros para todos os pedestres, interligados por ciclovias. Serão públicos se forem interessantes e disponíveis para todos. (TONUCCI, 2005, p.83)

A proposta de construção de espaços especializados também se torna uma medida autoritária ao impor seus usos, pois transforma os lugares em mercadorias que devem ser consumidas exclusivamente pelas crianças, excluindo-as de outras oportunidades urbanas de convívio, trocas de experiências e de possibilidades espontâneas e imaginativas de apropriação das áreas comuns da cidade. Outro aspecto negativo dessa especialização é que, geralmente, apresentam-se sob formas limitadas de utilização espacial, não estimulando a fantasia e a criação, que são elementos de grande importância dentro do processo de apropriação, descoberta e exploração infantil.

Atualmente, limitamos muito a experiência das crianças na cidade e não permitimos que elas brinquem "onde é possível brincar, mas nos lugares onde se deve brincar" (TONUCCl, 2005, p.44). Criamos e projetamos ambientes com brinquedos que determinam formas de brincar, ao mesmo tempo em que impossibilitamos que as 
demais áreas urbanas sejam apropriadas por suas expressões.

Sobre a produção desses locais exclusivos, Lima (1989, p.72) defende a hipótese de que "é preciso, pois, deixar o espaço suficientemente pensado para estimular a curiosidade e a imaginação da criança, mas incompleto o bastante para que ela se aproprie e transforme esse espaço através de sua própria ação."

O brincar para as crianças assume dimensões distintas das percepções dos adultos, para elas é uma forma de observar, investigar e descobrir o mundo, simular situações da vida adulta, estabelecer relações com os outros e com o mundo, inventar possibilidades novas, aprender e entender as regras do convívio coletivo.

Desse modo, não é possível que a brincadeira se realize sem que haja a disponibilidade de um espaço e de um tempo adequados. Portanto, analisar a importância que damos a essa atividade e aos espaços que destinamos a ela nas cidades é compreender também as relações entre os adultos e as crianças e o lugar que cada grupo assume na sociedade. Quando retiramos e ocupamos áreas destinadas às infâncias e limitamos a utilização da cidade de maneira ampla, estamos impossibilitando diferentes formas de desenvolvimento social; não é apenas o ambiente físico e material que desaparece, mas o conjunto de espaços que a sociedade permite que as crianças ocupem, envolvendo aí diversos fatores e condições para sua manifestação, seja por meio da brincadeira ou da presença política nesses locais. (LIMA, 1995). 


\section{4 "Eu brinco no prédio com os meus amigos" - leitura dos espaços públicos versus privados}

[fala de um dos meninos participantes das oficinas, ao descrever o desenho produzido, representando sua brincadeira preferida]

A cidade forma-se em seus espaços públicos - ruas, praça, parques, equipamentos públicos e coletivos - e privados - casas, instituições privadas. Cada uma dessas escalas possibilita envolvimentos e o estabelecimento de aprendizados bastante distintos aos seus cidadãos.

A partir das respostas dadas pelas crianças participantes dessa pesquisa, foi possível observar a presença predominante dos espaços privados - casas de familiares, pátios com brinquedos e equipamentos nos conjuntos habitacionais - em oposição às áreas públicas. Isso não significa uma negação ou uma completa exclusão dos meninos e meninas dos espaços públicos urbanos, mas um destaque às atividades realizadas de maneira resguardadas do estranho e do perigo, como foi relatado por seus pais.

De acordo com Queiroga (2012; 2014) ${ }^{47}$, há uma distinção entre espaços públicos e privados e esfera pública e privada, mas com estreitamento entre eles no que se refere as expressões culturais, sociais e políticas que se dão no urbano. Trazendo essas reflexões para o interesse dessa pesquisa, cabe entender os papéis das infâncias urbanas inseridas nessas duas dimensões: esfera e espaço.

Esfera pública é aquela que se opõem ao íntimo, ao privado, à família; é tudo que vem a público e ao domínio de todos. Ela pode ter uma dimensão de ações amplas, relacionando-se com a cultura, o cotidiano, o social ou ganhar uma dimensão política. (QUEIROGA, 2012)

Espaço público é todo aquele de propriedade pública, porém com diferentes graus de acessibilidade e apropriação, ou seja, podem ser de amplo acesso e domínio público ou áreas especiais com ingresso restrito. De semelhante maneira podem ser
${ }^{47} \mathrm{O}$ autor se baseia na construção teórica de: ARENDT, Hannah. A condição humana. $5^{\mathrm{a}}$ ed. Tradução de Roberto Raposo. Rio de Janeiro: Forense Universitária 1991; HABERMAS, Jurgen. Mudança estrutural da esfera pública: investigações quanto a uma categoria da sociedade burguesa. Tradução de Flávio Kothe. Rio de Janeiro: Tempo Brasileiro, 1984 SENNETT, Richard. O declínio do homem público: as tiranias da intimidade. São Paulo: Companhia das Letras, 1988. 
os espaços privados, que são reservados aos usos exclusivamente íntimos ou podem assumir dimensões públicas, possibilitando apropriações e manifestações dessa esfera. (QUEIROGA, 2012)

Como já foi abordado anteriormente, a infância foi delegada a esfera privada a partir do reconhecimento da criança como um sujeito distinto do adulto, com suas especificidades e necessidades. Desde esse momento, século XVII, a família começou a sentir a necessidade de maior privacidade e a escolarização surgiu com grande importância para a educação e a formação de seus filhos (ÀRIES, 2006). Somados a esses elementos, atualmente, a questão da segurança assume grande destaque ao se tornar um dos fatores responsáveis pela restrição da utilização das ruas e demais espaços livres públicos para o lazer e a sociabilização.

A partir de uma privatização da infância que reforça, cada vez mais, o papel da esfera e dos espaços privados no desenvolvimento das crianças, podemos observar que a família se fortalece, quase que exclusivamente, enquanto a única responsável pela articulação entre o íntimo e o social (CARDOSO, 2012). Dessa forma, exclui-se o compromisso da sociedade como um todo em zelar pelo atendimento, pela segurança e pela manifestação infantil na esfera de vida pública com reflexos diretos nos espaços públicos produzidos.

De forma concomitante, a diversificação das práticas cotidianas se delineia a partir de um redesenho contemporâneo entre os domínios público e privado. À medida que o espaço privado é ressignificado como lugar das crianças, se altera a relação que estabelecem com o espaço público. As causas desta reconfiguração não são unilaterais, nem oriundas apenas de um suposto perecimento do espaço público, e remontam, inclusive, às origens da distinção entre público e privado [...] (CARDOSO, 2012, p.37)

Acostumamo-nos com a reduzida presença das crianças nas áreas públicas e por isso, muitas vezes, não enxergamos esse fato como um problema, delegando-Ihes, na maior parte do tempo, os ambientes fechados, como casas, escolas e cursinhos, e esquecemo-nos de escutá-las sobre o que pensam a respeito. 
Nessa perspectiva, as casas de parentes e amigos assumem um papel de grande destaque nas vivências infantis, onde a sociabilidade recolhida ao espaço privado se opõe à sociabilidade urbana tradicional das áreas públicas. Tal fato teve grande destaque entre as crianças participantes dessa pesquisa, assumindo papel de importância nas representações de atividades cotidianas ocorridas aos finais de semana e nas brincadeiras preferidas.

Quando Jacobs (2011) defende uma vida ativa nas cidades, com "olhos para as ruas" e "a dança das calçadas", com seus movimentos constantes e observações atentas ao que se passa nos espaços públicos, ela está propondo que o meio urbano se forme como áreas em que os meninos e as meninas possam se desenvolver e assumir suas práticas sociais em segurança, sob a responsabilidade de todos os cidadãos.

[...] o princípio fundamental de uma vida urbana próspera: as pessoas devem assumir um pouquinho de responsabilidade pública pelas outras, mesmo que não tenham relação com elas. Trata-se de uma lição que ninguém aprende por Ihe ensinarem. Aprende-se a partir da experiência de outras pessoas sem laços de parentesco ou de amizade íntima ou responsabilidade formal para com você, que assumem um pouquinho da responsabilidade pública por você. (JACOBS, 2011, p.90)

Atualmente, quando vemos movimentos como o Childfree ${ }^{48}$ ou espaços que não permitem a presença de crianças estamos diante de uma ideia de infância, cada vez mais, restrita à esfera de vida privada, na qual não há uma responsabilidade coletiva por ela. No entanto essas manifestações devem ser encaradas não como uma forma de não solidariedade com a questão da infância, mas como uma manifestação preconceituosa, ilegal e inconstitucional, que vai contra aquilo previsto pela Constituição Brasileira ${ }^{49}$ (BRASIL, 2017) - direito à dignidade da pessoa humana; não haver preconceito de idade; dever da família, do Estado e da sociedade na promoção da convivência comunitária sem discriminação - e estabelecido pelas normativas da Convenção sobre os Direitos da Criança (BRASIL, 1990) e do Estatuto da Criança e do Adolescente (BRASIL, 2016) para a garantir os direitos das crianças e dos adolescentes.

\footnotetext{
${ }^{48}$ O movimento Childfree ("livre de crianças" ou "sem filho") começou a ganhar força nos Estados Unidos, nos anos de 1970, com a intenção de agrupar adultos que não queriam ter filhos e se sentiam discriminados pela sociedade por essa opção de constituição familiar. No entanto, atualmente, presentes no mundo inteiro, inclusive no Brasil, esses grupos também passaram a adotar um discurso de "não gosto de crianças" ou "não quero crianças por perto", reivindicando que estabelecimentos de uso coletivo que não aceitem o público infantil, alegando que muitas não sabem se comportar e perturbam. Esses movimentos ganham um campo de encontros e discussões também no ambiente virtual das redes sociais.

${ }^{49}$ Arts. $1^{\circ}, 3^{\circ}$ e 227 da Constituição da República Federativa do Brasil. Brasília 2017.
} 


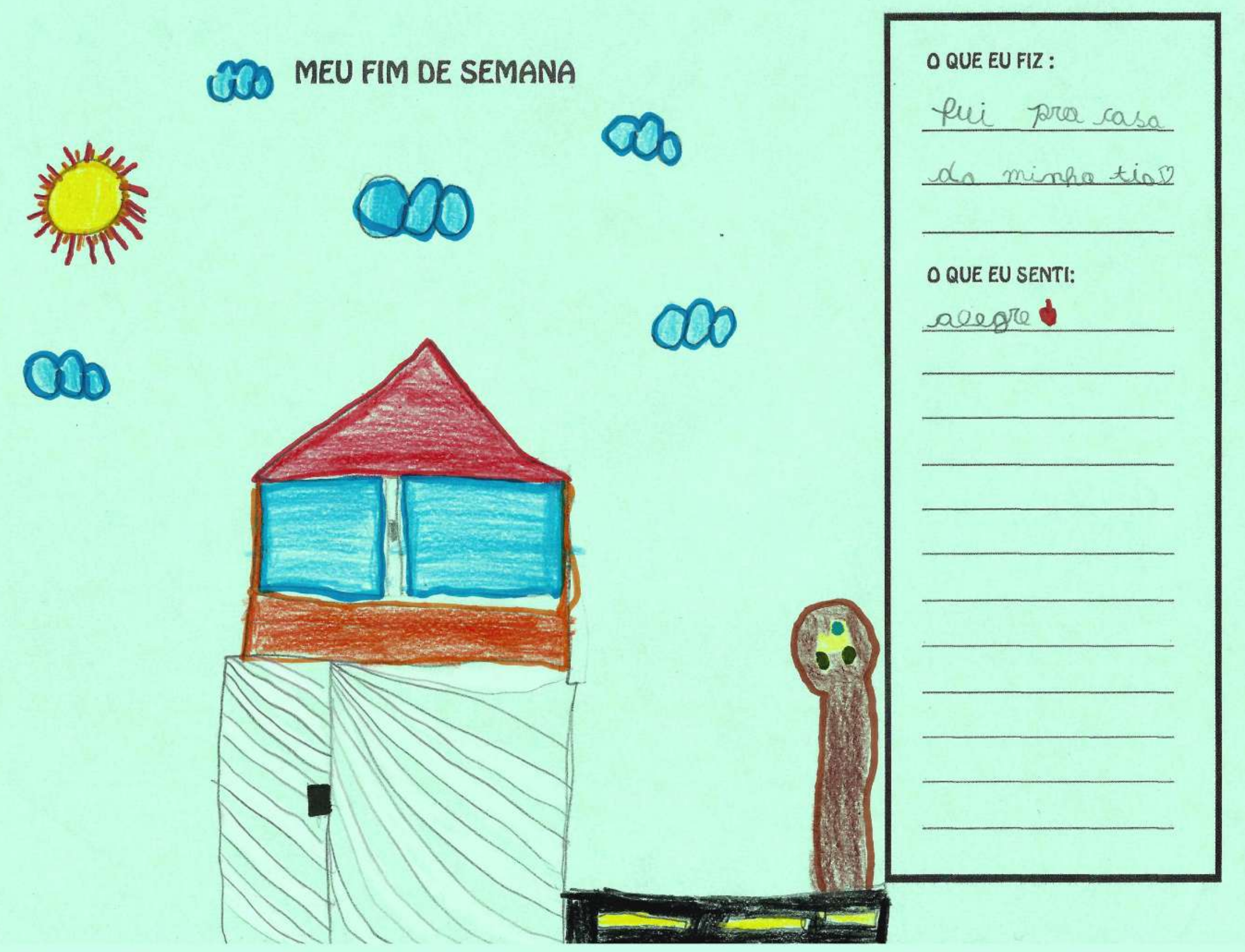


FIGURA 71 [verso]

Desenho elaborado por Bárbara. Casa da tia, em resposta ao questionamento sobre 'o que você fez no fim de semana?' Canetinha hidrográfica, lápis de cor e grafite sobre papel sulfite na cor verde $210 \mathrm{~mm} \times 297 \mathrm{~mm}$, setembro de 2016.

Fonte: Arquivo pessoal, 2016 
Em uma realidade urbana como a que é aqui trabalhada, na qual há a predominância do estabelecimento da infância dentro da esfera privada, cabe às crianças acolher concessões ou permissões dos adultos para o uso dos espaços públicos. Logo, a possibilidade de vivenciar experiências na esfera pública está diretamente ligada ao modo como a infância é vista pelo universo adulto; se é encarada como frágil e dependente, sua autonomia ficará prejudicada e inviabilizada por uma postura autoritária.

Dessa forma, a presença de espaços privados que possibilitam a apropriação pública ou a manifestação da escala de vida pública torna-se cada vez mais frequente nas áreas urbanas. Fato que pôde ser observado pelos desenhos produzidos pelos meninos e meninas participantes dessa pesquisa, nos quais os parquinhos dentro dos empreendimentos habitacionais ganharam grande destaque como locais utilizados cotidianamente e como construções desejadas, ao surgir na proposta de elaboração de um projeto para a cidade.

Tonucci não interpreta essas áreas condominiais como elementos negativos no processo de sociabilização e de manifestação da esfera de vida pública. Segundo o autor,

os pátios condominiais devem ser considerados espaços das primeiras e das últimas autonomias: as crianças, mesmo nos primeiros anos, devem poder sair de casa e encontrar-se com os pequenos amigos, cuidados pelas mães ou pelos pais debruçados na janela; os idosos que não estão mais com vontade de sair sozinhos podem ficar sentados em um banco lendo o jornal, observando as crianças que brincam, falando com um amigo.[...] [No entanto,] muitas vezes os pátios condominiais foram transformados em estacionamentos e dificilmente os adultos renunciam aos benefícios obtidos para seus automóveis. (TONUCCI, 2005, p.39)

A constituição e a manutenção dessas áreas condominiais, que ganharam uma importância muito grande nos cenários urbanos brasileiros, está fortemente marcada pela questão da segurança. São espaços privados voltados ao lazer e 
que, de certo modo, possibilitam experiências de vida na esfera pública, através do encontro com aqueles moradores que também frequentam o mesmo local, sem a necessidade da exposição ao ambiente público. No entanto, por se localizarem em conjuntos habitacionais de promoção estatal, os espaços retratados pelas crianças não assumem as características das áreas condominiais de edifícios residenciais da classe média e alta, com uma infinidade de equipamentos e atividades disponíveis. Porém, sua função, tomadas as devidas proporções, é a mesma: criar um local para o lazer infantil protegido dos perigos das ruas e da cidade, no qual as crianças poderiam brincar com maior liberdade.

Se pensarmos na implantação dos condomínios fechados destinados às classes médias e altas, podemos ainda colocar outras reflexões sobre a produção dos espaços urbanos que esses empreendimentos possibilitam. De acordo com Caldeira (2000), quando a cidade se transforma, construindo enclaves fortificados - como os condomínios fechados, os shopping centers, as áreas particulares monitoradas e vigiadas constantemente - que negam o ambiente externo, o caráter dos espaços públicos também se altera e com ele há uma mudança na participação dos cidadãos na vida pública.

Essa situação, na maioria das vezes, é geradora de ambiguidades muito grandes, exercendo um papel determinante nas áreas públicas, sobretudo na rua, que é o contato direto com os ambientes privados. Ao mesmo tempo em que asseguram a interação social através dos espaços internos de uso coletivo, possibilitam a transformação do exterior em um ambiente inseguro, já que a relação público-privado se faz pelo intermédio de grandes muros ou grades e, muitas vezes, com seguranças armados. Quanto à esfera pública, as experiências que se dão nesses locais também são impactadas negativamente, pois reproduzem a segregação, possibilitando o contato apenas entre iguais através da busca da constituição de um espaço público artificial e idealizado dentro de áreas privadas e restritas. 


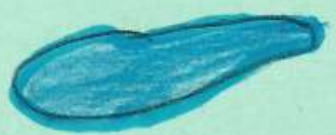

MEU EIM DE SEMANA

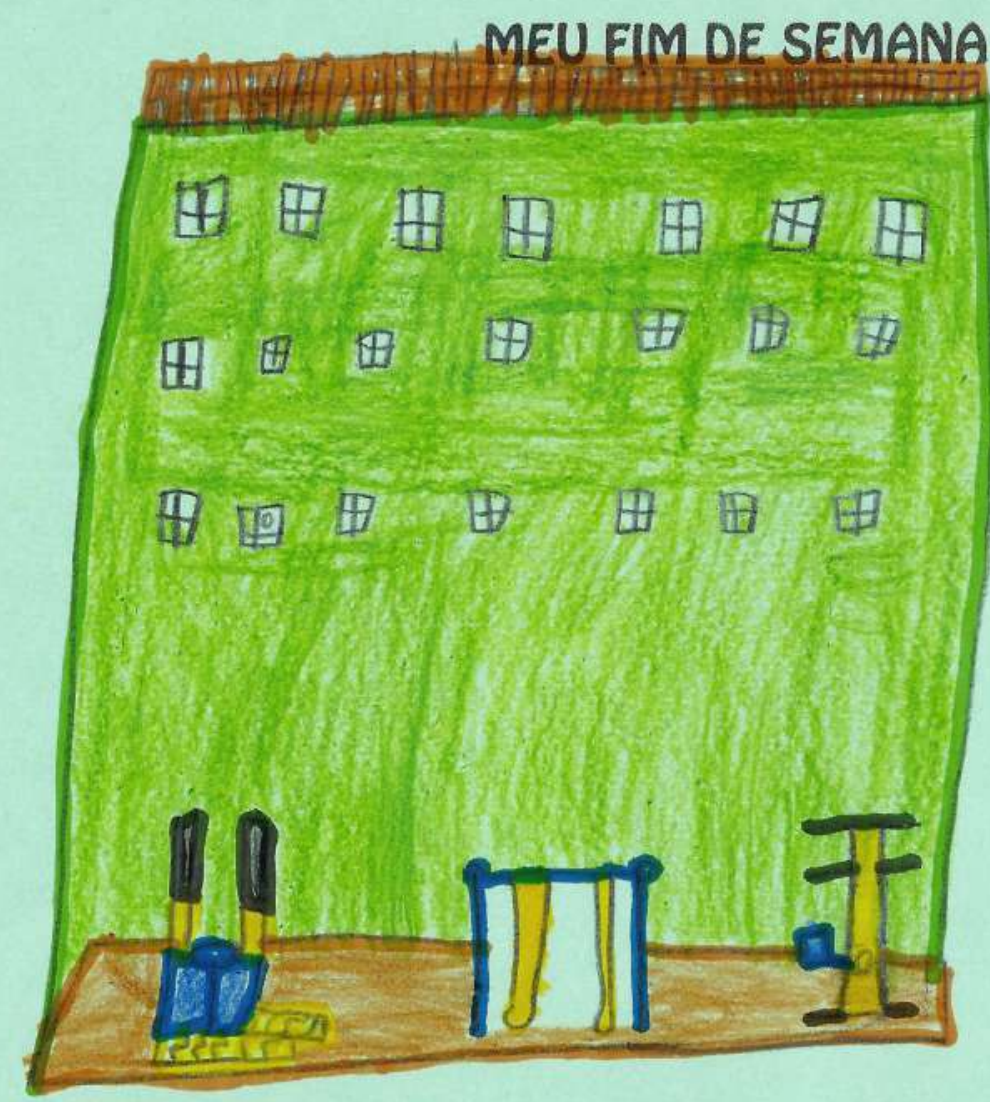

O QUE EU FIZ:

brinqueli no

parquinho

O QUE EU SENTI:

peliz 
FIGURA 72 [verso]

Desenho elaborado por Nicolly. Parquinho no prédio onde mora, em resposta ao questionamento sobre 'O que você fez no fim de semana?' Canetinha hidrográfica, lápis de cor e grafite sobre papel sulfite na cor verde $210 \mathrm{~mm} \times 297 \mathrm{~mm}$, setembro de 2016 .

Fonte: Arquivo pessoal, 2016 


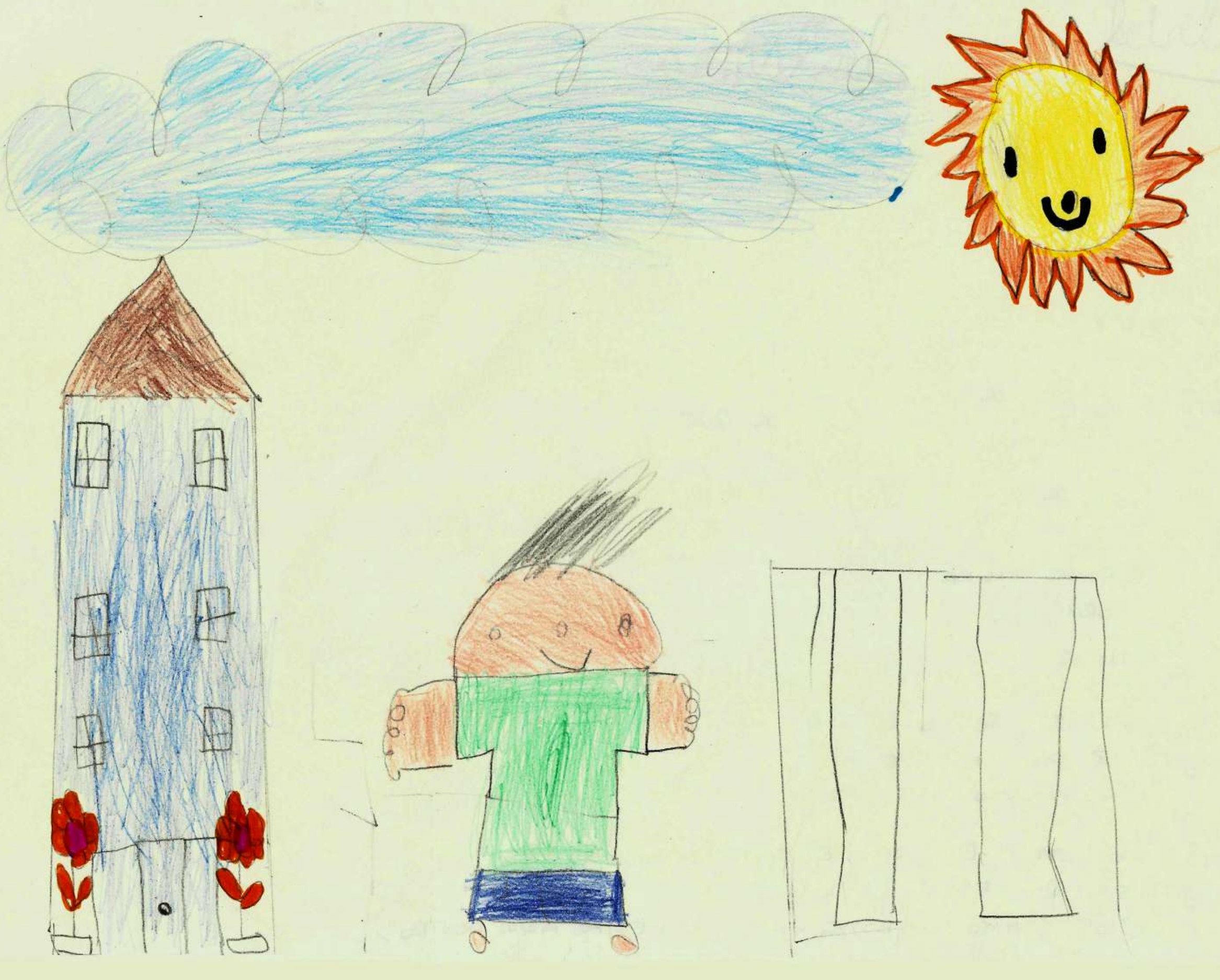


"A brincadeira que eu mais gosto é o balanço. E eu brinco com os meus amigos, que estão aqui dentro do prédio." (Gabriel)

\section{FIGURA 73 [verso]}

Desenho elaborado por Gabriel. Brinquedos no parquinho do prédio onde mora, em resposta ao questionamento sobre 'qual brincadeira você mais gosta?' Lápis de cor e grafite sobre papel sulfite na cor marfim $210 \mathrm{~mm} \times 297 \mathrm{~mm}$, outubro de 2016 .

Fonte: Arquivo pessoal, 2016. 
50 Representação dos percursos casa -escola, investigação e localização dos equipamentos e moradias através de foto aérea dos bairros e visita no entorna da escola.
A partir desses aspectos, criam-se situações urbanas em que o público e o privado são colocados em antítese, como se um não necessitasse do outro para existir; como se a total negação do espaço público fosse possível, ainda que se opte pela vida dentro dos 'enclaves fortificados', como os denominou Caldeira (2000).

Como já foi dito anteriormente, é no espaço público que se dá o encontro com o desconhecido, o diferente e os riscos, sendo possível a ampliação de conhecimentos, experiências, cidadania, cultura, civilidade e sociabilidade, ou seja, é o local onde a esfera de vida pública pode se desenvolver de maneira ampla.

Se a vida privada e social tem nos espaços edificados seu maior abrigo, a vida pública tem seu maior suporte físico-material para ocorrer nos espaços livres públicos, são eles os espaços de maior acessibilidade, de maior capacidade para receber a diversidade, a pluralidade e o imprevisto, características de uma esfera pública mais rica. (QUEIROGA, 2014, p.120-121)

Dessa forma, cabe destacar também, que as expressões infantis produzidas durante as oficinas que compõem essa pesquisa, possibilitaram reflexões no sentido não de uma negação do espaço público pelas crianças, mas de uma seleção de funções que cada lugar adquire dentro das experiências cotidianas. Aparentemente, diante das manifestações através dos desenhos, falas dos meninos e meninas e relatos de seus pais, os espaços públicos são pouco utilizados com autonomia e para as práticas de lazer, que quando ocorrem são acompanhadas por adultos. No entanto, diante das atividades que exigiram um conhecimento e uma relação direta com o bairro ${ }^{50}$, foi possível observar que o domínio espacial e a familiaridade que as crianças têm com esses locais é reflexo de suas experiências vividas nessas áreas, sobretudo através da circulação. Nessa perspectiva, ainda que a rua seja um dos principais espaços públicos utilizados cotidianamente, a autonomia infantil ainda é muito limitada devido as questões de segurança e proteção apresentada pelos adultos.

Para Jacobs (2011, p.29) as ruas são a principal expressão do urbano; se elas "parecerem interessantes, a cidade parecerá interessante; se elas parecerem 
monótonas, a cidade parecerá monótona." E ainda, "quando temem as ruas, as pessoas as usam menos [restringindo também seus usos pelas crianças], o que torna as ruas ainda mais inseguras." (JABOBS, 2011, p.30) Fato que pode ser interpretado dentro de um ciclo, pois quanto mais inseguro é um espaço, menos as pessoas, incluindo as crianças, irão frequentá-lo; e quanto menos pessoas e crianças frequentarem um espaço, mais inseguro ele se tornará. "É preciso ajudar as cidades a acostumarem-se novamente às crianças nas ruas." (TONUCCl, 2005, p.78)

\section{5 "Eu vim a pé para a escola. Vi árvores, prédios, carros, a escola,} gente, perua e a moça do doce na frente da escola" - leitura dos afetos e identidades

[fala de uma das meninas participantes das oficinas, ao descrever o percurso realizados de sua casa até a escola]

"A relação do indivíduo com a cidade se constitui a partir do tipo de envolvimento que estabelece com o espaço urbano" (CARDOSO, 2012, p.25). Para as crianças essa ligação é mediada também pelo modo como elas são vistas pelos adultos e pelas oportunidades que thes são concedidas nesses locais.

O contato infantil com os espaços urbanos se dá muito além da materialidade construída. É potencializada a relação de exploração, descoberta, construção de identidade e possibilidades de usos, que refletem medos, segurança, familiaridade, estranhamento, possibilidades, restrições, experiências positivas e negativas, afetos, desafetos, conhecimentos, histórias contadas pelos adultos, aventuras, desafios e pertencimentos que esses lugares despertam.

As crianças apresentam uma relação com os espaços que está muito ligada ao que elas sentem e podem fazer neles; para elas "existe o espaço-alegria, o espaço- 
medo, o espaço-proteção, o espaço-mistério, o espaço-descoberta, enfim os espaços da liberdade ou da opressão" (LIMA, 1989, p.30), que podem se definir nas inúmeras áreas públicas ou privadas, de acordo com as relações estabelecidas em cada uma.

As oficinas realizadas com as crianças possibilitaram, sobretudo em três atividades - observação e desenho do percurso de casa até a escola; visita de campo no entorno da escola com registro fotográfico e visita ao Jardim Botânico, com a produção de desenhos de observação -, o contato e o envolvimento mais íntimo com a cidade, que iremos denominar como experiências paisagísticas.

A paisagem entendida aqui pressupõe a presença humana e não é vista como algo distante ou "para ser olhada, é inserção do homem no mundo, lugar de um combate pela vida, manifestação de seu ser com os outros, base de seu ser social." (DARDEL, 2013, p.102).

Diante disso e a partir da proposta das crianças de se colocarem na cidade para explorá-la não apenas de maneira apartada, mas através de suas percepções, sentidos e afetos proporcionados por esses espaços, julgou-se conveniente tal denominação.

Segundo Simmel (2013, p.20), para que exista paisagem

é preciso justamente que tal conteúdo singular do campo da visão cative nosso espírito. Para que haja paisagem, a consciência deve apreender, além dos elementos, um novo conjunto, uma nova unidade, não ligados aos significados particulares de cada elemento, nem composto mecanicamente de sua soma.

Desse modo, pode-se dizer ser também uma perspectiva estética - palavra de origem grega, aisthesis, que significa inspirar e era usada para expressar a percepção ou a sensação -, entendida aqui no sentido oposto de anestesia (an + aisthesis), a partir da qual se propõe que o sujeito, no nosso caso, as crianças, estejam na cidade percebendo-a e integrando-se a ela pelas sensações. (HILLMAN, 1993)

Para Hillman (1993) a experiência de estar no mundo e percebê-lo é resultado de um envolvimento entre a alma do ser e a alma do mundo - anima mundi - que são 
inseparáveis, mas distintas, sendo o homem reflexo do mundo e o mundo reflexo do homem. 0 autor propõe o pensamento de uma cidade que tem alma, a qual precisamos entendê-la e reavivá-la para que ela se faça presente dentro de nós, trazendo identidade e cumplicidade.

[...] o mundo sem alma nunca pode oferecer intimidade, nunca retribui o meu olhar, nunca me olha com interesse, gratidão, nem alivia o isolamento absoluto da minha subjetividade. Mas, no momento em que cada coisa, cada acontecimento se apresenta novamente como uma realidade psíquica [...], então sou absorvido numa conversa íntima e duradoura com a matéria. (HILLMAN, 1993, p.25)

Talvez essa tenha sido a dinâmica das crianças nas oficinas realizadas, pois observou-se que elas permitiram-se envolver de modo não superficial com a "alma do mundo". Nesse sentido, os percursos infantis se afastam dos objetivos dos percursos dos adultos, que têm como propósito a conexão entre dois pontos.

Para os adultos, principalmente os moradores de regiões metropolitanas, como São Paulo, a observação dos elementos presentes nos caminhos não são, na maioria das vezes, objetos de interesse, pois os deslocamentos carregam também a questão relativa ao tempo utilizado: quanto mais rápido é possível chegar a um lugar, mais eficiente será a locomoção, ainda que para isso a cidade deixe de ser percebida e vá apartando-se, cada vez mais, de sua memória.

Para as crianças, no entanto, os percursos carregam outros significados: a descoberta, o encantamento e uma relação mais intensa e subjetiva com o mundo. É no caminhar que os espaços urbanos assumem suas feições, positivas ou negativas, que irão auxiliar nos processos de construção de identidade e de memória, principalmente naquelas áreas vivenciadas cotidianamente. Para elas o percurso é "feito de muitos pontos intermediários, cada um dos quais sendo mais importante do que o ponto de chegada, que representa apenas o fim das descobertas e da aventura." (TONUCCl, 2005, p.89) É no percurso que também está a cidade e a sua alma. "[...] a razão mais importante de se ir de um lugar para o outro é ver aquilo que há entre os dois lugares..." (HILLMAN, 1993, p.56) 


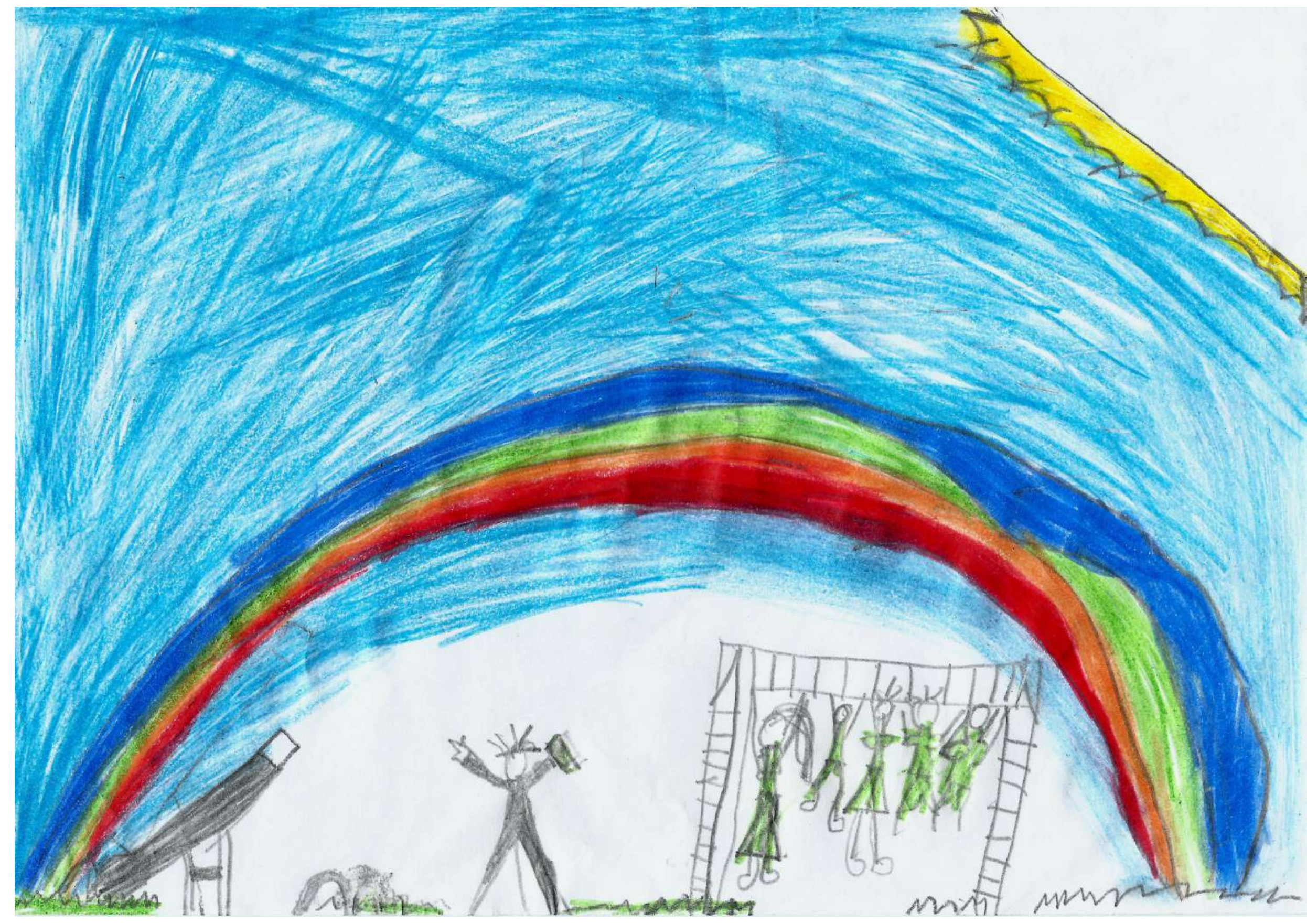


FIGURA 74 [verso]

Desenho elaborado por Pyetra. Registro após visita ao entorno da escola identificando o momento em que chegaram ao Parque Linear do Córrego do Fogo e subiram no brinquedo (trepa-trepa) para um registro fotográfico. Lápis de cor e grafite sobre papel sulfite branco, $210 \mathrm{~mm}$ x 148mm, setembro de 2016.

Fonte: Arquivo pessoal, 2016. 

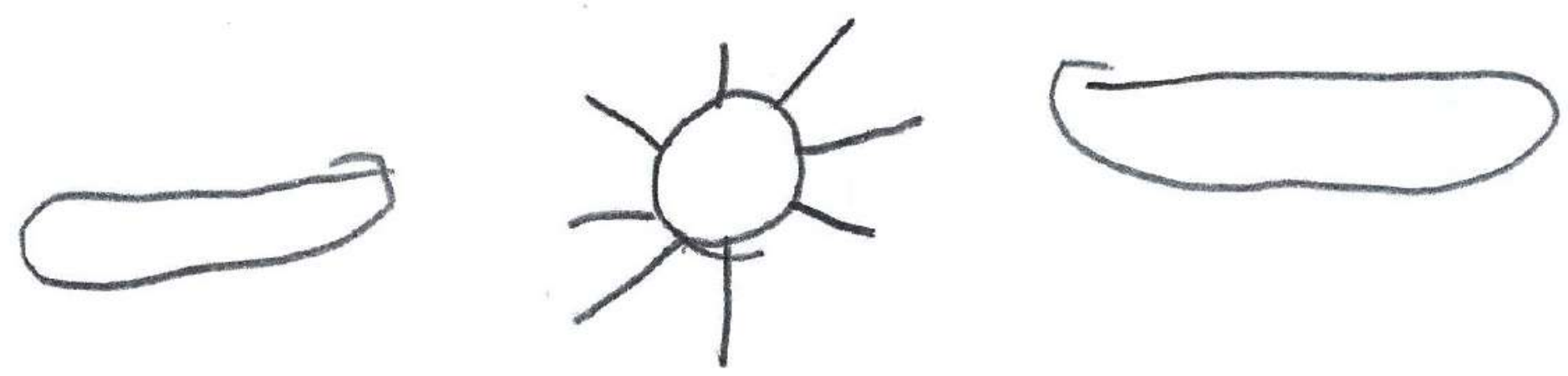

$2 \frac{29}{x+4}$
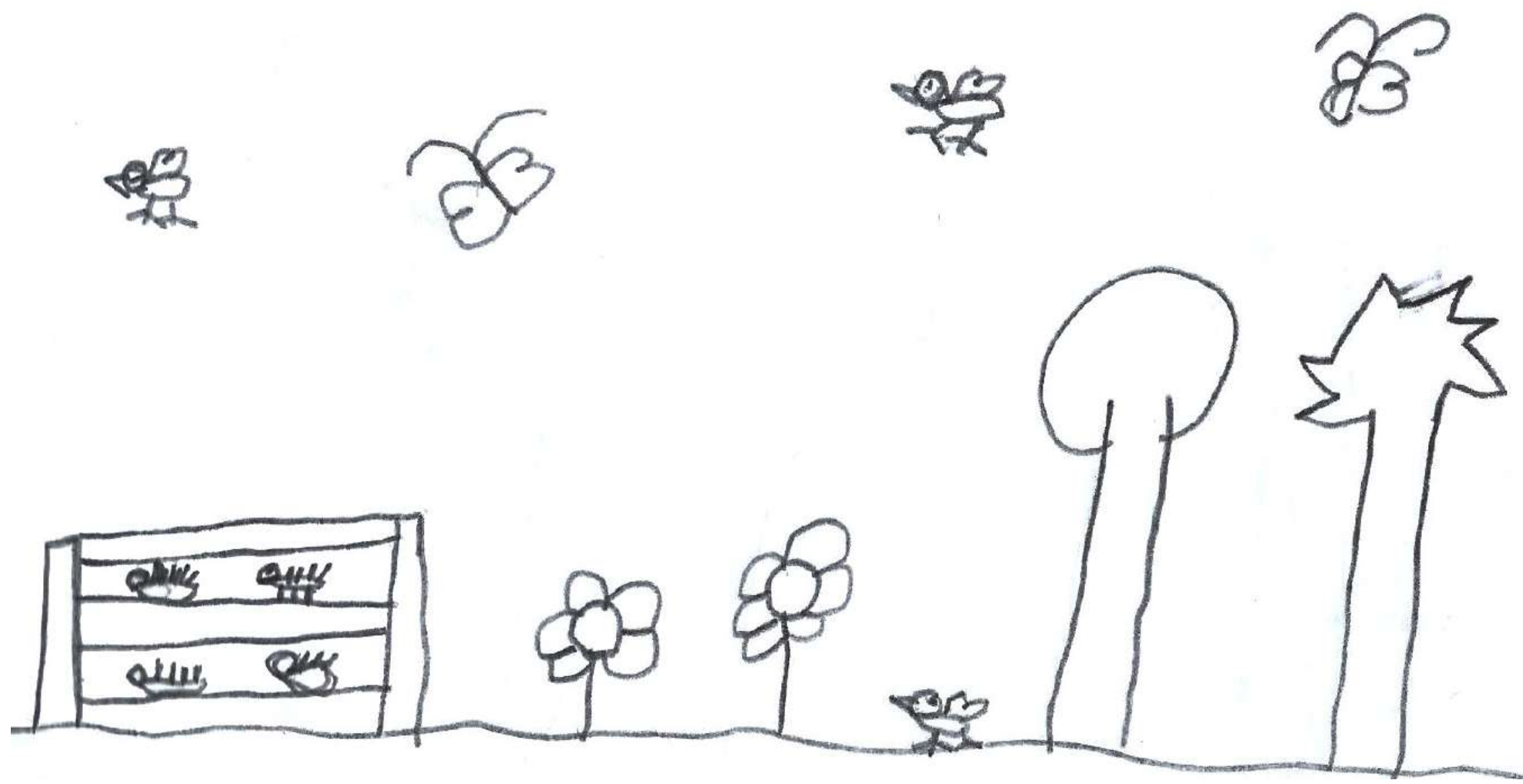
FIGURA 75 [verso]

Desenho elaborado por Thainá. Registro durante visita ao Jardim Botânico identificando elementos observados no local: lagartas ao longo da Trilha da Nascente, pica-pau, borboletas, flores, árvore e palmeira. Lápis grafite sobre papel sulfite branco, 150mm x 105mm, novembro de 2016.

Fonte: Arquivo pessoal, 2016. 
Podemos identificar a partir dos processos e das produções realizadas pelas crianças sujeitos dessa pesquisa - desenhos e fotografias - que os espaços não foram vistos como elementos estranhos e afastados, mas como algo que possibilitou uma experiência paisagística, tanto nos ambientes mais familiares dos bairros onde moram e estudam quanto em um lugar não conhecido, como o Jardim Botânico. Nessas atividades, o percurso foi o meio através do qual o ambiente foi percebido e o caminhar ganhou grande destaque como possibilidade de se relacionar com o mundo e com os outros.

"Mas o espaço não é apenas o lugar da imaginação poética: ele é também fruto de conhecimentos objetivos, lugar de relações vitais e sociais concretas, e determinado por elementos materiais que modificam a sua natureza e qualidade." (LIMA, 1989, p.14)

Dessa forma, caminhar pelos espaços rotineiros possibilita às crianças uma leitura e uma relação mais estreita com a sua cidade cotidiana, de modo bastante distinto daqueles que a observam com um olhar externo e, muitas vezes, estranho.

O olhar interior sobre os territórios, aquele dos grupos sociais que os produzem, utilizam e habitam é constitutivo do seu envolvimento e da sua memória. Ele engendra relações endógenas opostas às relações exógenas precedentes. 0 que este olhar espera não é o motivo do quadro da paisagem para ser admirado, nem a consumação lúdica de um lugar, mas o reconhecimento identitário de um território balizado por espaços familiares ou desconhecidos. Os lugares assim identificados provêm da história local dos grupos sociais e de suas inscrições visíveis ou invisíveis. A memória dos conflitos sociais está ali localizada, do mesmo modo que os ritos [...] comemorativos ou festivos. (DONADIEU, 2013, p.56)

Os afetos, as percepções e as relações estabelecidas por cada criança na cidade se faz de maneira única. Cada uma

constitui a cidade da sua infância. E cada cidade assume um contorno, mais pública ou muito privada, mais amigável ou nada amistosa, fértil de encontros e cheia de percursos ou a cidade que se vê pela janela do carro. De qualquer forma, se constituirá como experiência singular para toda e qualquer criança ou adolescente em qualquer contexto urbano. (CARDOSO, 2012, p.134) 
Será a partir dessas relações estabelecidas, mais especificamente nos bairros onde moram enos espaços cotidianos, que se constituem outras formas de manifestação da infância na esfera pública. A familiaridade, o pertencimento e a construção da identidade se dão a partir dos significados e das vivências adquiridas nesses locais e das formas que os meninos e meninas são afetados por eles. É um processo que acontece duplamente: a cidade se mostra em sua infinidade de possibilidades, instigando as crianças às descobertas; enquanto as crianças se colocam disponíveis e abertas para se envolverem, com seus corpos e sentidos, pela cidade.

Inscritas nos lugares e fortalecidas por eles, as crianças tornamse "outro" - cidadãs -, através da vivência do espaço urbano e das complexas relações sociais e culturais ali desenvolvidas. Desse modo, a cidadania, não como um dado natural, mas como uma aprendizagem fundamentalmente social, pode transformar-se em um estado de espírito enraizado na cultura (SANTOS, $1996^{51}$, apud DIAS; FERREIRA, 2015, p.126).

Dessa maneira, além dos sentimentos individuais produzidos pelos espaços urbanos nas crianças, a construção de identidades infantis nesses locais possibilita também o estabelecimento do pertencimento a esses territórios, onde a cidadania e o reconhecimento delas enquanto sujeitos sociais de direitos podem ser fortalecidos e potencializados.
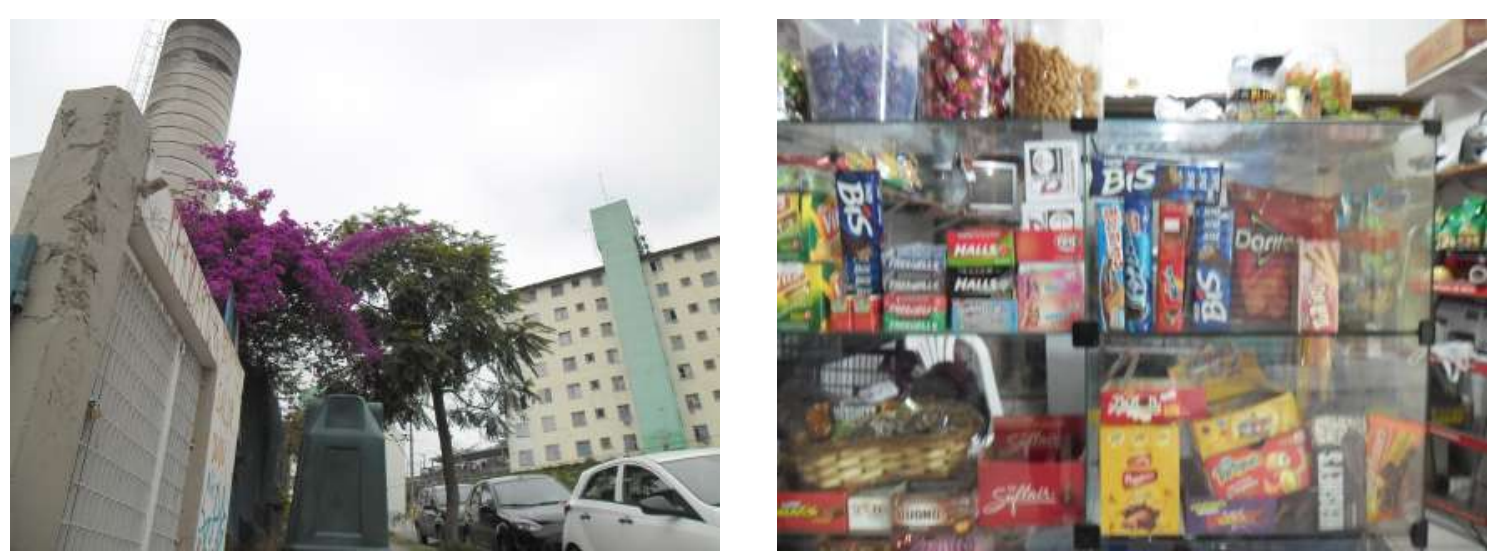

\section{FIGURA 76 [esquerda]}

Fotografia feita pelo grupo de Danilo e Gabriel durante visita ao entorno da escola. Máquina fotográfica digital, setembro de 2016.

Fonte: Arquivo pessoal, 2016.

\section{FIGURA 77 [direita]}

Fotografia feita pelo grupo de Danilo e Gabriel durante visita ao entorno da escola. Máquina fotográfica digital, setembro de 2016

Fonte: Arquivo pessoal, 2016.

51 SANTOS, Milton. O espaço do cidadão. São Paulo: Nobel, 1996. 


\section{FIGURA 78 [superior esquerda]}

Fotografia feita pelo grupo de Deyvid, Livia e Pyetra durante visita ao entorno da escola. Máquina fotográfica digital, setembro de 2016.

Fonte: Arquivo pessoal, 2016.

\section{FIGURA 79 [superior direita]}

Fotografia feita pelo grupo de Débora, Guilherme e Thainá durante visita ao entorno da escola. Máquina fotográfica digital, setembro de 2016.

Fonte: Arquivo pessoal, 2016

\section{FIGURA 80 [inferior esquerda]}

Fotografia feita pelo grupo de Maria Eduarda, Nicolly e Yasmim durante visita ao entorno da escola. Máquina fotográfica digital, setembro de 2016.

Fonte: Arquivo pessoal, 2016

\section{FIGURA 81 [inferior direita]}

Fotografia feita pelo grupo de Débora, Guilherme e Thainá durante visita ao entorno da escola. Máquina fotográfıca digital, setembro de 2016.

Fonte: Arquivo pessoal, 2016
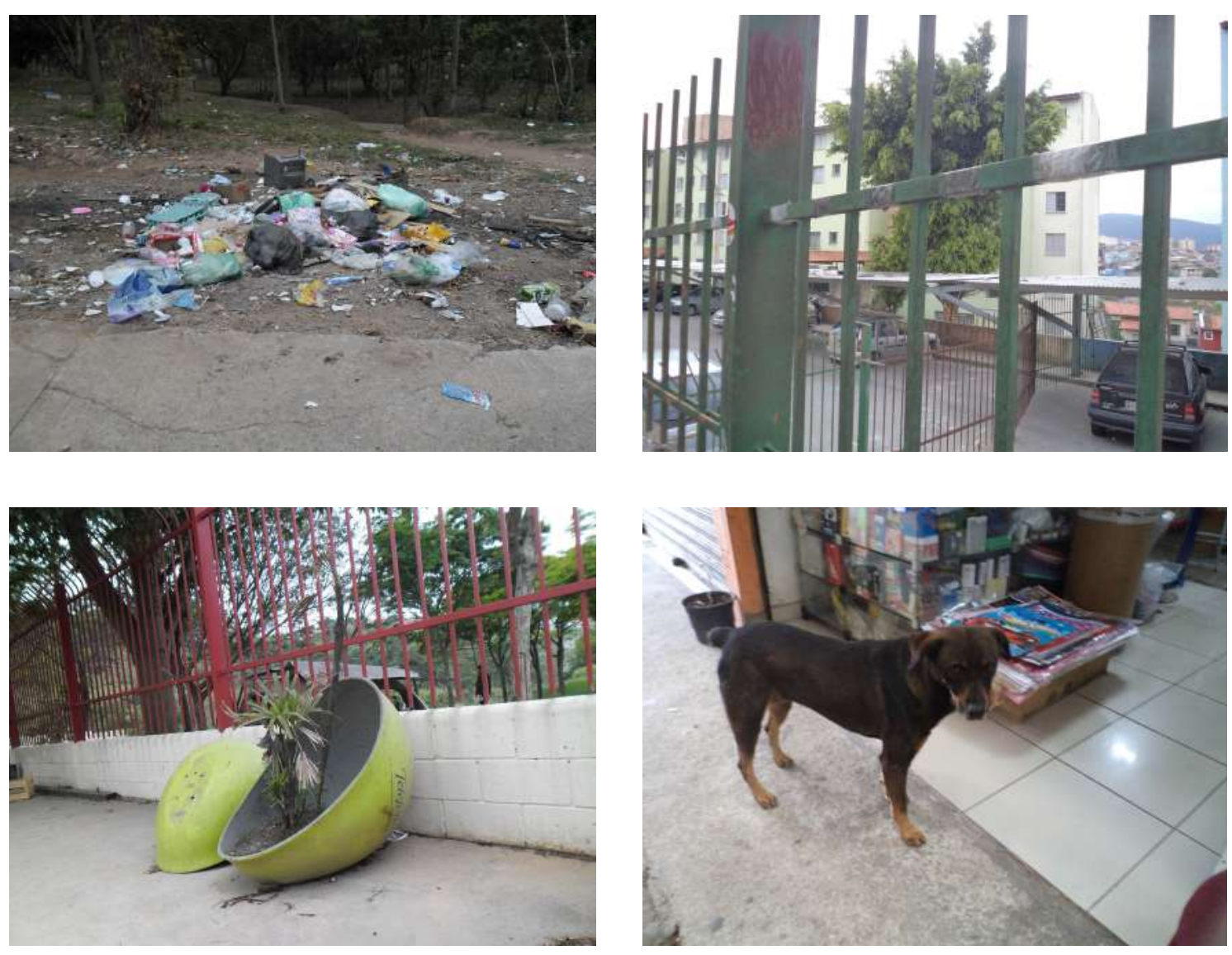

A identificação destes cinco eixos de interpretação permitiu a construção de uma imagem múltipla do Jaraguá visto através das observações das crianças, em que elas se colocaram também na posição de pesquisadoras, investigando aspectos urbanos existentes em suas vivências nos espaços cotidianos.

No capítulo seguinte serão abordados os projetos e a participação infantil como possibilidades de transformação da cidade. 


\section{CAPÍTULO 4}

PROJETOS E PARTICIPAÇÃO: OS DESEJOS DAS CRIANÇAS PARA TRANSFORMAR A CIDADE E O JARAGUÁ

O homem seria metafisicamente grande

se a criança fosse seu mestre.

Soren Kierkegaard ${ }^{52}$

52 In: BARROS, Manuel. Menino do mato. 1ª ed. Rio de Janeiro: Objetiva/ Alfaguara, 2015. 


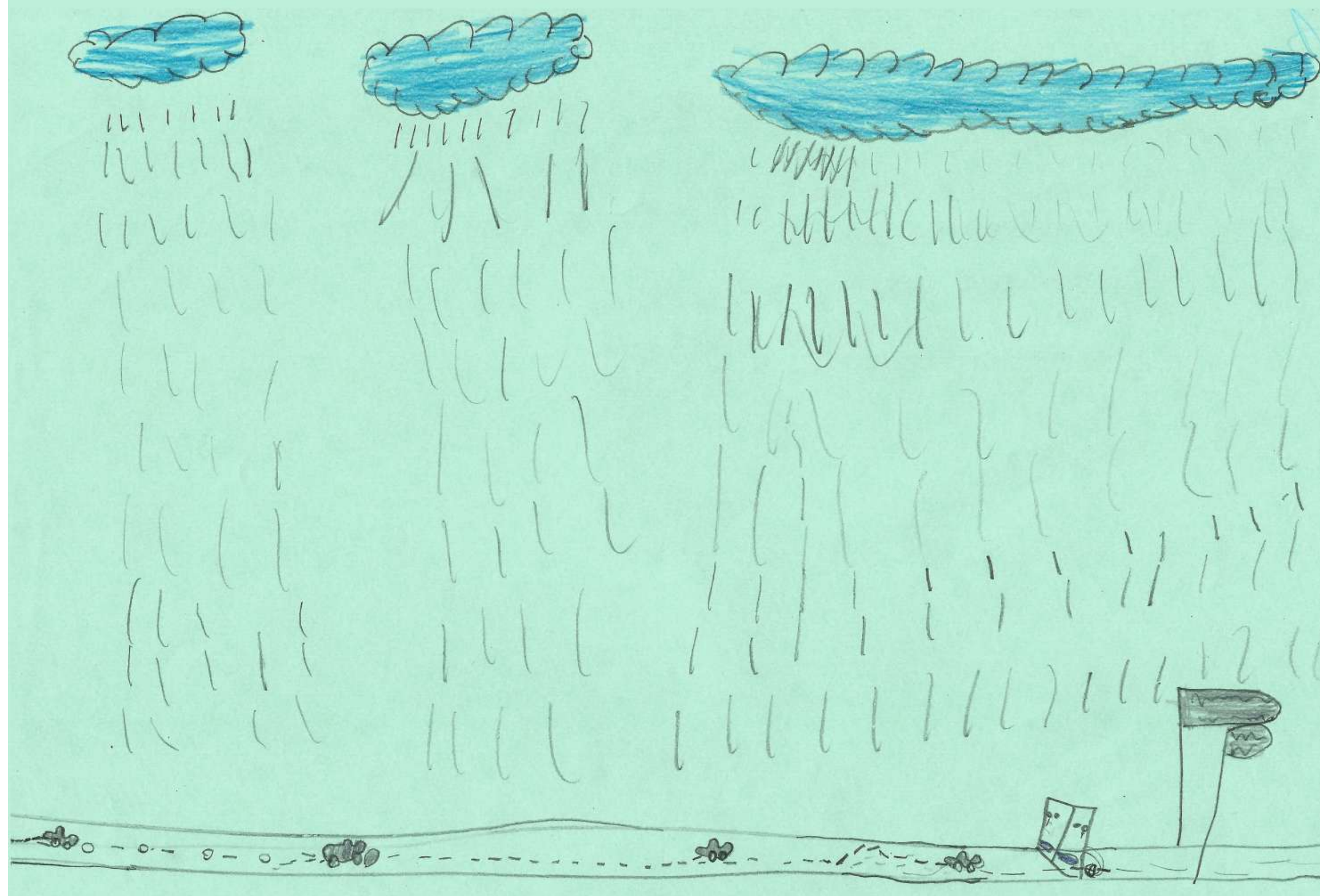


"Eu gostaria que consertasse os buracos das ruas, porque aqui tem muito buraco nas ruas e quando chove fica pior ainda." (Davi)

\section{FIGURA 82 [verso]}

Desenho elaborado por Davi. Consertar os buracos das ruas em resposta ao questionamento sobre 'o que você gostaria que tivesse no seu bairro?' Lápis de cor e grafite sobre papel sulfite na cor verde, $210 \mathrm{~mm}$ x $297 \mathrm{~mm}$, outubro de 2016.

Fonte: Arquivo pessoal, 2016. 
Nos campos da Arquitetura, do Urbanismo e do Paisagismo, de modo geral, as crianças têm pouca participação na construção dos espaços urbanos. Quando projetos arquitetônicos e urbanísticos voltam-se para elas, pouquíssimas são as vezes em que são minimamente consultadas ou têm a oportunidade de participar desses processos de maneira mais ampliada.

No entanto, é justamente esse comportamento que se pretende transformar ao trazer meninos e meninas para pensar a cidade junto com os profissionais que a projetam - arquitetos, urbanistas, planejadores urbanos, geógrafos, engenheiros e administradores públicos.

As formas de apropriação dos espaços públicos de seus bairros, as possibilidades (ou não) de deslocamentos autônomos e a avaliação que as crianças fazem desses locais são influenciadas diretamente pelo projeto arquitetônico e urbanístico e pela postura política que eles assumem, que é de responsabilidade daqueles que os planejam. Desse modo, além da materialidade que é construída, a concepção de infância(s) que esses profissionais e estudiosos urbanos carregam, torna-se um dos fatores determinantes para suas práticas projetuais, ou seja, se para eles as crianças são (e devem continuar sendo) 'invisíveis' na cidade, os projetos continuarão a ignorálas e excluí-las, atendendo a prioridades colocadas pelos interesses das classes dominantes. Se, ao invés disso, esses profissionais forem sensíveis às infâncias urbanas e entenderem que a cidade é um direito de todos os cidadãos, independente da faixa etária à qual pertençam, teremos projetos mais democráticos de espaços e de sociedade.

Diante dessa realidade e, ainda hoje, no século XXI, testemunhando muitos espaços públicos se configurarem como tiranos em seus desenhos e em sua forma de distribuição dentro da cidade, onde as crianças permanecem controladas por adultos (LIMA, 1989), esse capítulo se propõe a investigar o potencial presente nos projetos e nas ações dos sujeitos participantes dessa pesquisa, visando a transformação urbana, partindo-se de seus espaços e vivências cotidianas. 
Antes de aprofundar as propostas elaboradas pelas crianças é importante entender como elas são entendidas socialmente e quais as possibilidades de participação que assumem dentro do contexto em que estão inseridas.

Para refletirmos sobre a participação infantil e como ela é concebida, é importante destacar que os pontos aqui trabalhados não devem ser encarados de maneira generalista, tanto devido ao cenário em que se inserem quanto dentro das perspectivas adultas que os interpretam. As questões levantadas devem ser analisadas e contextualizadas em uma realidade urbana de uma cidade ocidental metropolitana, onde as distinções de faixas etárias e da construção da infância são fortemente marcadas pela não visibilidade da criança enquanto sujeito de direito à cidade. Apesar de existirem projetos que trabalham na contramão dessa postura, eles não são predominantes. Além disso, cabe salientar também que, de modo geral, as crianças ainda assumem uma posição de inferioridade em relação aos adultos, principalmente quando são envolvidas questões referentes à política; novamente, são poucos os projetos que assumem uma perspectiva de colocá-las presentes nessas discussões.

A restrição de direitos políticos à infância, característica da modernidade ocidental, não tem, todavia, um carácter universal. Sociedades e comunidades radicadas no oriente e no hemisfério sul, ou mesmo grupos étnicos minoritários na Europa, não se caracterizam pela exclusão das crianças da vida coletiva e, inclusive, incluem as crianças nas assembleias e espaços de decisão coletiva, com efetiva participação cívica. (SILVA; MACEDO; NUNES, 200153; REDDY; RATNA, $2002^{54}$ apud SARMENTO; FERNANDES; TOMÁS, 2007, p.184-185).

\subsection{Participação infantil}

"A etimologia da palavra 'participação' vem do latim participatio que significa 'tomar parte'. As crianças fazem parte da sociedade, mas não lhes foi dado o direito concreto de 'tomar parte' principalmente nos assuntos que as afetam diretamente." (OLIVEIRA, 2017, p. 162)
53 SILVA, Aracy Lopes; NUNES, Angela; MACEDO, Ana Vera (Orgs.). Crianças indígenas. Ensaios antropológicos. São Paulo: Global, 2001

${ }^{54}$ REDDY, Nandana; RATNA, Kavita. A journey in children's participation. Índia: Concerned for Working Children, 2002. 
Quando pensamos na participação infantil em propostas e políticas urbanas, essa se dá de forma quase que inexistente ou é praticamente nula, pois, na maioria das vezes, as crianças são vistas como sujeitos dependentes, incompletos e incapazes para opinar e contribuir naquilo que lhes dizem respeito.

A forma pela qual se fala sobre crianças na sociedade moderna é extremamente confusa. Se alguém disser que as crianças são seres humanos, ninguém discordará, embora esse status seja constantemente colocado em dúvida, visto que as capacidades e competências infantis são supostamente incompletas se comparadas às de uma pessoa completamente crescida; as crianças também não são cidadãs, no sentido mais abrangente do termo, pois não têm, por exemplo, a oportunidade de atuar como membros de uma sociedade democrática; elas têm direitos, mas estão longe de ter todos os direitos dos quais os adultos dispõem. (QVORTRUP, 2014, p.25)

Possibilitar que elas atuem e participem das decisões urbanas é concebê-las como atores sociais e considerá-las nos vários âmbitos da sociedade, principalmente e sobretudo, nos espaços públicos. "Essa participação se configura como uma participação política das crianças consideradas como cidadãs." (OLIVEIRA, 2017, p.158)

Tomando-se como base essa perspectiva, o campo da Sociologia da Infância oferece importantes contribuições para compreender a atuação da criança como ator social, sujeito de direitos, com visibilidade e capaz de expressar sua opinião utilizandose das mais distintas formas e linguagens comunicativas. Desse modo, ela deixa o lugar de menor importância dentro da sociedade e das pesquisas, assumindo um papel social que até então não lhe era proporcionado pelos adultos.

Tomás (2007, p.45) defende

uma concepção de cidadania ativa e crítica que concebe às crianças e jovens como atores sociais imprescindíveis e participativos na sociedade, implicando não só o reconhecimento formal de direitos, mas também as condições do seu exercício por meio de uma plena participação. 
Ao colocar meninos e meninas dentro de um processo de pesquisa, no qual eles não são objetos de estudo, mas sujeitos e copesquisadores (ALDERSON, 200855, apud FARIAS; MULLER, 2017, p.264) que investigam e propõem, há o emprego de uma abordagem multidisciplinar e complexa, como ela realmente é, apresentando particularidades em decorrência de seus locais de vivência e da cultura na qual se inserem. Da mesma maneira devemos pensar a cidade, que se forma a partir de questões de grande complexidade que não merecem apenas a atenção do urbanismo, do planejamento urbano ou da engenharia; deve ser encarada a partir da multiplicidade das relações sociais, econômicas, políticas e humanas que se estabelecem nos espaços produzidos.

A criança é produto da cidade e das relações sociais e culturais que se dão nesse local, mas também pode ser ator político e agente de transformação desses espaços. A cidade, de modo semelhante, também é produto e fator determinante das relações humanas que se estabelecem nela. São elementos que se interligam, se complementam e promovem, simultaneamente, suas construções.

Considerar a criança como agente e sujeito atuante nos processos de transformação urbana implica na alteração de postura dentro da relação de poder com os adultos, ou seja, a maneira como elas são concebidas influencia diretamente nas formas de participação (ou não participação) nos espaços públicos. 0 adulto, nesse contexto, tem um papel de grande importância, pois pode exercer uma posição hegemônica e adultocêntrica na relação criança-adulto-sociedade-cidade.

Cabe destacar que a desigualdade no tocante à participação das diferentes faixas etárias é fruto e está relacionada com a estrutura e o contexto social no qual os cidadãos estão inseridos. "Em última análise, a inobservância dos aspectos fundamentais dos direitos das crianças repousa no cruzamento de variáveis econômicas, sociais e culturais." (SARMENTO; PINTO, 1997, p.5)

O olhar adulto, muitas vezes, considera haver uma falta de competência infantil para a participação social e política (fato que pode ser ainda mais reforçado
55 ALDERSON, Priscilla Children as Researchers. In: CHRISTENSEN, Pia; JAMES, Allison (Orgs.). Research with Children: perspectives and practices. London: Routledge, 2008. 
quanto menor é a faixa etária). Há uma crença de que as crianças devem aprender a ter responsabilidades, antes de receber direitos e de participar. Essa compreensão leva a uma invisibilidade infantil nos espaços públicos, diminuindo ou anulando suas possibilidades de atuação nos processos de tomada de decisão, já que são vistas com capacidades inferiores a partir de seu aspecto biológico: imaturas, desprotegidas e dependentes. (OLIVEIRA, 2017)

Ao mesmo tempo em que as crianças ganharam maior atenção e cuidados para suprir suas supostas fragilidades, vulnerabilidades e incompletudes, começaram a se afastar do mundo adulto, da vida comunitária e política, sendo impossibilitadas de se envolver nas decisões sociais, tornando-se, cada vez mais, sujeitos privados, subordinados à unidade doméstica e invisíveis nos espaços públicos. Hoje, há uma grande especialização de serviços e produtos privados para atender as necessidades criadas para elas, enquanto que a cidade e os espaços de usos coletivos e públicos usam-se da justificativa de insegurança e de não adaptação para excluir suas presenças desses locais. Desse modo, a proteção e a participação infantil são colocadas em contradição.

A partir de uma perspectiva da infância privatizada, restrita à família e às instituições de ensino, onde ocorrem medidas protecionistas exageradas, reforço do poder adulto e subordinação infantil, alimenta-se a ideia de uma exclusão das crianças da cena pública e da participação política.

Quando falamos em participação política entendemo-la além das garantias eleitorais, que as crianças não têm. Estamos propondo que os meninos e meninas sejam vistos como atores políticos que se manifestam através de seus direitos e demandas de maneira não eleitoral (SARMENTO; FERNANDES; TOMÁS, 2007).

Segundo Sarmento (1997), há uma distinção entre os três "p" - proteção, provisão e participação - que enxerga as crianças de modos distintos, favorecendo o distanciamento entre a proteção e a provisão da noção de participação. Desse modo, apoiados por uma postura paternalista, que considera os meninos e meninas incapazes 
e imaturos, necessitando exclusivamente da provisão de meios essenciais ao seu desenvolvimento e de cuidados especiais de proteção, os adultos julgam conveniente retirar-Ihes dos papéis de atores sociais e políticos, destinando-Ihes apenas a função de receptores de medidas protetoras, sem atribuição do direito à participação social e à partilha das decisões de seus mundos de vida.

A participação política infantil, como um direito de cidadania, só pode ser conquistada a partir do momento em que as crianças são consideradas sujeitos sociais e cidadãs (SARMENTO; FERNANDES; TOMÁS, 2007). Com base nessa conceituação, podemos pensar que elas têm acesso a diferentes formas de participação, desde aquelas meramente consultivas, nas quais suas opiniões não têm força para produzir mudanças e transformações e, por isso tornam-se ilusórias, até um envolvimento amplo nos processos desde o início, com oportunidades de fazer escolhas, decidir e produzir uma real transformação.

Diante disso, cabem algumas indagações: qual é a participação que queremos ou esperamos das crianças? Enquanto adultos, estamos dispostos a compartilhar de pontos de vistas distintos e possibilitar que elas opinem em questões e decisões que irão afetar os demais cidadãos? Até que ponto estamos preparados para aceitar as crianças como cidadãs ativas e participativas?

Segundo Lansdown (2005 56 apud TOMÁS, 2007) é possível identificar três níveis distintos e com diferentes graus de participação infantil, que não se excluem entre si:

1. processos consultivos, nos quais os adultos controlam e administram as diferentes etapas e resultados, reconhecendo as opiniões e as experiências das crianças, mas privando-as de um controle e uma participação mais ampliada.

2. processos participativos, são iniciados por adultos, mas há uma colaboração infantil que exerce influência sobre os processos e os resultados;

3. processos autônomos, são caracterizados pela ação ampliada das crianças, que controlam e interferem nos temas a serem abordados e na maneira como
56 LANSDOWN, Gerison. ¿Me haces caso? El derecho de los niños pequeños a participar en las decisiones que los afectan. Cuadernos sobre Desarrollo Infantil Temprano n.36. La Haya, Paises Bajos: Fundación Bernard van Leer 2005. 
os processos irão acontecer; os adultos atuam como facilitadores.

Talvez não seja possível chegar a um processo autônomo de participação infantil sem passar pelas etapas inicialmente consultivas e com maior controle dos adultos. No entanto, não estamos querendo construir uma escala de evolução a partir da identificação de Lansdown, pretendemos apontar apenas para a diversidade possível de processos participativos, com maior ou menor intensidade de envolvimento das crianças. Da mesma forma, também é importante destacar que muitas atividades ou processos considerados participativos, utilizam-se dessa descrição apenas para ganhar destaque no meio social e político, mas são descaracterizados

por via da cooptação ou da integração noutras atividades e propósitos por parte dos adultos, e muitas vezes os processos participativos são apenas ritualísticos, manipuladores e prejudiciais para as crianças. Nisto reside a vulnerabilidade e ambiguidade da participação das crianças: a sua cooptação pelos adultos (aproveitamento político, marketing, etc.) e/ou a sua integração em contextos institucionais (controle, descaracterização e interesse, concepções e atores hegemônicos). (TOMÁS, 2007, p.50)

Se não há uma disponibilidade em rever as relações adulto-criança com abuso de poder sobre elas, não é possível que a participação infantil se efetive. Esse fato pode ser fortemente observado no contexto brasileiro, excetuando-se poucos casos, como por exemplo, a relação dentro de algumas tribos indígenas, nas quais as crianças têm maior inserção nas atividades coletivas, compartilhando dos aprendizados do meio adulto. Segundo Cohn (2005, p.28), as crianças xikrin ${ }^{57}$

[...] não simplesmente aprendem as relações sociais em que têm e terão que se engajar ao longo da vida, mas atuam em sua configuração. [...] Certamente, haverá relações possíveis a elas, outras impossíveis; umas dadas e inevitáveis, outras mais abertas à construção. No entanto, e de acordo com a margem de manobra que Ihes é dada culturalmente, as crianças xikrin constroem grande parte das relações sociais em que se engajarão durante a vida. [...] a criança não é apenas alocada em um sistema de relações que é anterior a ela e reproduzido eternamente, mas atua para o estabelecimento e a efetivação de algumas das relações sociais dentre aquelas que o 
sistema Ihe abre e possibilita.

Nessa perspectiva, há o estabelecimento da criança atuante,

que tem um papel ativo na constituição das relações sociais em que se engaja, não sendo, portanto, passiva na incorporação de papéis e comportamentos sociais. Reconhecê-lo é assumir que ela não é um 'adulto em miniatura', ou alguém que treina para a vida adulta. É entender que, onde quer que esteja, ela interage ativamente com os adultos e as outras crianças, com o mundo, sendo parte importante na consolidação dos papéis que assume e de suas relações. (COHN, 2005, p.27-28)

A partir da compreensão da criança como sujeito responsável e capaz de atuar dentro dos espaços sociais, estabelece-se o reconhecimento de sua participação na esfera de vida pública. Baseado nos apontamentos de Oliveira (2017), é possível considerar que essa participação é democrática quando:

- As crianças estão inseridas e envolvidas nos processos desde o início, compreendendo os objetivos dos projetos e quais são seus papéis neles;

- As relações de poder com os adultos são equilibradas e compartilhadas em todas as etapas, desde o planejamento até a conclusão e a avaliação do projeto;

- Todas as crianças são tratadas com igualdade de direitos, levando-se em consideração suas diversidades de idades, etnias e habilidades; a participação deve ser inclusiva;

- For voluntária, podendo-se optar pela permanecia ou a saída do projeto em qualquer estágio em que ele se encontrar;

- São respeitadas e valorizadas as perspectivas e as experiências infantis, possibilitando que, através de metodologias adequadas, as manifestações das diversas formas de expressão possam oferecer subsídios para captar os vários pontos de vista.

A forma de expressão e o modelo de participação infantis, para serem realmente democráticos, devem considerar as especificidades das crianças - faixas etárias e 
cultura - e se adequar aquelas representações que lhes fazem sentido, sem replicar os mecanismos adultos, inadequados à linguagem infantil.

[...] descobrir, através do recurso à imaginação interventora, modalidades de participação compatíveis com as culturas infantis, formas de comunicação atentas aos modos de expressão das crianças (daí, por exemplo, a importância do desenho e do cartaz como forma de expressão) e canais de diálogo com o poder constituído, seja numa perspectiva assertiva de reivindicação, seja numa perspectiva de acompanhamento e interlocução direta. (SARMENTO; FERNANDES; TOMÁS, 2007, p.196).

A participação infantil é assegurada legalmente pelo artigo 12 da Convenção sobre os Direitos da Criança ${ }^{58}$, aprovada pelo Unicef em 1989 e instituída pelo Brasil em 1990, e pelo artigo 16 do Estatuto da Criança e do Adolescente ${ }^{59}$, de 1990 e atualização posteriores, que garantem à criança o direito de expressar sua opinião sobre questões que lhe digam respeito e de tê-la levada em consideração para a tomada de decisões no âmbito da vida comunitária e política.

Participar é um dos principais instrumentos na formação de uma atitude democrática. Quem participa ativamente da vida pública de uma comunidade, de uma cidade, estado ou país, torna-se sujeito de suas ações, é capaz de fazer críticas, de escolher, de defender seus direitos e também de cumprir melhor os seus deveres. (UNICEF, 2013, p.26)

Para mais informações ver: BRASIL. Decreto n 99.710, de 21 de novembro de 1990. Promulga a Convenção sobre os Direitos da Criança. Brasília, DF, 22 nov. 1990. Disponível em: <http:// www.planalto. gov.br/ccivil_03/decreto/1990-1994/d99710.htm>. Acesso em: 22 jan. 2018.

${ }^{59}$ Para mais informações ver: BRASIL. Estatuto da criança e do adolescente (1990). Estatuto da criança e do adolescente [recurso eletrônico]. Lei n. 8.069, de 13 de julho de 1990, e legislação correlata. 15. ed. Brasília, DF: Câmara dos Deputados, 2016. Disponível em: <http:// bd.camara.gov.br/bd/ handle/bdcamara/18403>. Acesso em: 22 jan. 2018. 
da Infância confirmarem a competência das crianças, na prática, esse argumento não é realizado, caracterizando-as como sujeitos vulneráveis, como forma de justificar a postura protetora do adulto, que as exclui da participação.

Temos que admitir que crianças são tanto fisicamente menores quanto menos experientes mental e socialmente e, por isso, o argumento de Marx se aplica, ou seja, direitos iguais sob condições desiguais é equivalente a direitos desiguais (Marx, 187560). Por outro lado, uma ênfase extrema na suposta vulnerabilidade pode ser utilizada por segmentos mais poderosos como pretexto para silenciar e marginalizar as crianças. (QVORTRUP, 2014, p.34)

0 autor ainda traz uma importante reflexão sobre o caráter dialético da vulnerabilidade, da proteção e da participação, ao questionar não apenas a vulnerabilidade infantil, mas também a do adulto. Se analisarmos a estrutura urbana e a qualificação dos adultos, elas também são extremamente frágeis ao não acolherem as necessidades infantis e tornam-se receosas quanto a uma possível perda de autoridade. Ao evitar que as crianças participem e acessem essas estruturas e organizações, estamos buscando protegê-las da suscetibilidade que esses mecanismos procuram negar, que é a de não adaptação à participação de todos os cidadãos, sendo, também, uma forma de não reconhecer a falta de preparo adulta, que busca um modo de silenciar as crianças. (QVORTRUP, 2014)

Lima (1989) aponta ainda para um desconforto e uma necessidade do adulto ter o controle sobre a criança e sobre as suas manifestações.

[...] precisamos sentir-nos donos da situação, ter presente todas as alternativas que a criança poderá escolher, porque só assim nos sentiremos seguros. A liberdade da criança é a nossa insegurança, enquanto educadores, pais ou simples adultos, e, em nome da criança, buscamos nossa tranquilidade, impondo-lhes até os caminhos da imaginação. [...] A insegurança não diz respeito apenas ao medo de que as crianças fiquem expostas a possíveis perigos, pois estes são reais e podem ser controlados objetivamente; o medo maior é o do desconhecido, do novo que pode surgir na ação das crianças e que pode colocar-nos diante da necessidade de nos repensarmos enquanto profissionais, enquanto pessoas que dominam o saber e,
${ }^{60}$ MARX, Karl. Critique of the Gotha-Programme: Marx/Engels selected works. v. 3. Moscow: Progress Publishers, 1970 [1875]. 
No entanto, cabe reforçar que a participação infantil não significa que as crianças irão fazer e decidir tudo sozinhas, tornando-se emancipadas. É um processo de negociação, construção e estabelecimento de direitos, embasados por relações mais horizontais e simétricas com os adultos. Faz-se necessário entender também quais são os limites e as responsabilidades infantis, além das diferenças entre seus direitos políticos e civis comparados aos adultos, a fim de não chegarmos ao equívoco de considerá-las vulneráveis e inferiores (TOMÁS, 2007). Trata-se do reconhecimento da cidadania da infância, no qual há o equilíbrio entre a proteção adulta e o estabelecimento de seus direitos de cidadania e participação. (SARMENTO; FERNANDES; TOMÁS, 2007)

Essa atuação infantil deve ser vista como um processo e não como um fim, no qual é possível consolidar-se outros direitos, obter justiça, influenciar resultados e denunciar abusos de poder (TOMÁS, 2007). Dessa forma, a participação também pode ser encarada como uma constante que faz parte do desenvolvimento e do crescimento das crianças, ajudando-as em sua construção no mundo.

A questão não é somente que as crianças e os adolescentes opinem sobre a cidade, mas que também assumam responsabilidades como cidadãos em âmbitos que, de uma forma ou de outra, lhes pertencem e que, como consequência, têm de aprender a administrar e a melhorar. (GÓMEZ-GRANELL; VILA, 2003, p.27)

A partir do reconhecimento das crianças como cidadãs, Tonucci (2005) defende que elas não sejam enquadradas apenas dentro dos papéis de alunos, necessitados ou doentes, mas se tornem atores sociais de respeito em sua condição atual e não como uma projeção do futuro e do que virão a ser. Elas precisam do apoio, da proteção e dos ensinamentos dos pais, professores e demais adultos, mas também têm a necessidade de conhecer o mundo por si mesmas, explorando, maravilhando-se e descobrindo coisas novas. Através da elaboração de aprendizados que lhes façam sentido, tornamse capazes de construir conhecimento e cidadania próprios e de colaborar nesses processos de outras pessoas.

A participação infantil não se resume apenas ao direito das crianças serem 
vistas como sujeitos políticos e sociais, mas também está ligada aos seus direitos à cidade, podendo apropriar-se desses lugares com as suas mais distintas formas de expressão - chorando, brincando, explorando, descobrindo, correndo, engatinhando, gritando - e também através de sua participação com propostas para modificação desses espaços.

0 direito à cidade é, portanto, muito mais do que o direito ao acesso individual ou grupal aos recursos que a cidade incorpora: é um direito de reinventar a cidade mais de acordo com nossos mais profundos desejos. Além disso, é um direito mais coletivo do que individual, uma vez que reinventar a cidade depende inevitavelmente do exercício de um poder coletivo sobre o processo de urbanização. (HARVEY, 2014, p.28)

Reconhecendo os direitos sociais e políticos assumidos pelas crianças e seu processo de participação, faz-se importante refletir sobre possibilidades de integrá-los aos projetos participativos arquitetônicos e urbanísticos, que podem ser potencializados enquanto instrumentos para encarar a complexidade urbana, possibilitando maiores usos e apropriações pelos diferentes públicos usuários.

Quando as crianças têm a oportunidade de se envolver em processos participativos para a elaboração de espaços públicos urbanos, auxiliando desde a elaboração até a apropriação e a manutenção destes locais, podemos observar que se estabelecem relações íntimas com seus significados simbólicos e funcionais.

O ônus da não inserção dos cidadãos no processo de projetar (independentemente dos métodos e técnicas que possam vir a ser utilizados para a aferição dos seus desejos, percepções, necessidades) pode representar a consolidação de ambientes 'ecologicamente corretos', artisticamente bem elaborados, mas que se esvaziam no hermetismo da proposta e não facilitam sua apreensão pela sociedade. (LIMA, 1996, p.189)

A participação em arquitetura, sobretudo para a construção de espaços públicos, envolve um leque de possibilidades, desde simples consultas à população até a colaboração nos programas e projetos, passando pela execução da obra e sua 
gestão. No tocante à identificação de seus usuários, é possível que ocorra "um exercício de ampliação de uma perspectiva, visando à incorporação, na prática, da crença nas suas capacidades de opinar, criar e gerir o espaço onde vivem." (PEREIRA, 2006, p.50)

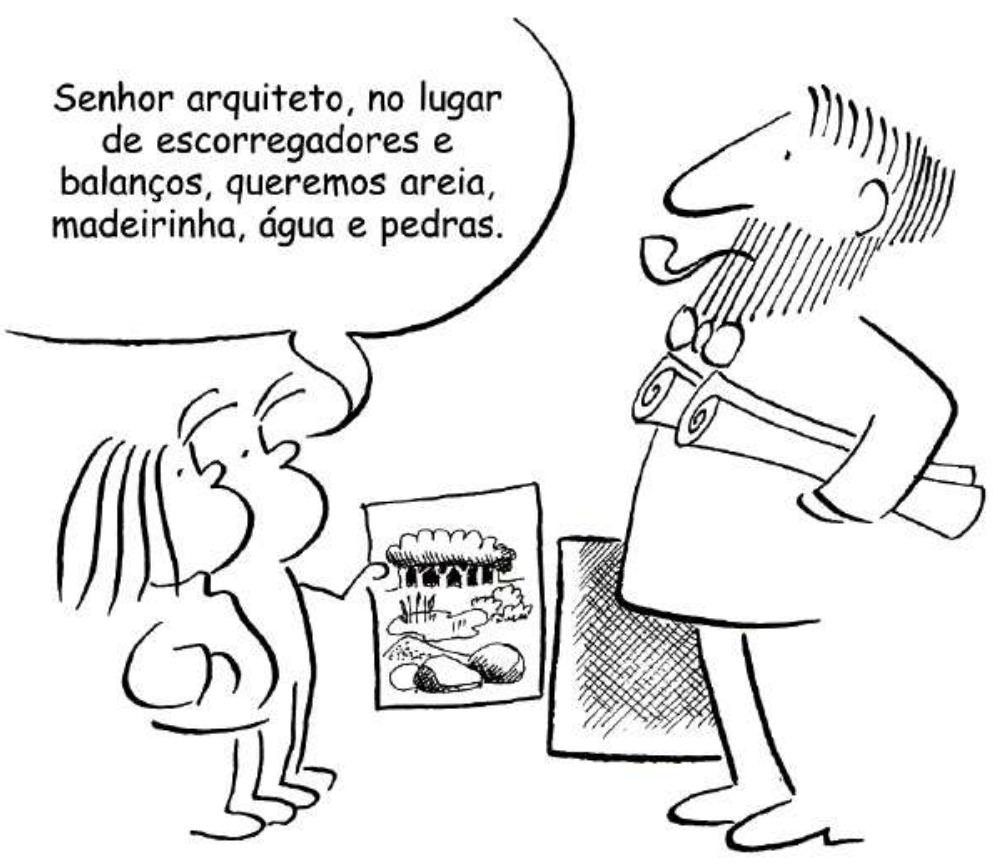

FIGURA 83

FRATO94

Fonte: TONUCCI, 2008.

Quando pensamos em projetos de espaços livres públicos, a necessidade de processos participativos torna-se ainda mais latente. Inicialmente, devem estar adequados para atender as diversas demandas que surgem de seus usuários. Com a implantação do projeto, a manutenção e os cuidados posteriores se fazem primordiais para a integridade do local, pois, além da parte construída, essas áreas também englobam aspectos biofísicos e elementos vivos - flora e fauna - que possuem certa fragilidade e atenção constante. Esses locais concentram, numa micro-escala, 
as contradições do viver urbano, solicitando uma postura mais interativa com seus vivenciadores para a manutenção e a preservação de seus projetos e usos. (PEREIRA, 2006)

As crianças, nesse cenário, destacam-se como um grupo de usuários com interesses especiais, que são potencializados pelos processos participativos na medida em que, além de discutir a cidade, desenvolvem também reflexões e maneiras de viabilizar sua inserção nos espaços públicos, reforçando seus papéis, direitos políticos e sociais e a construção de uma cidadania da infância.

$\mathrm{Na}$ contramão de uma perspectiva da criança dependente e sem direito à participação, acrescida de uma postura arquitetônica e urbanística de projetar a cidade de maneira participativa, em que todos os cidadãos têm o direito de colaborar para a tomada de decisões urbanas, na sequência serão apresentadas propostas elaboradas pelos meninos e meninas participantes dessa pesquisa, com proposições de transformação dos seus espaços urbanos cotidianos, visando uma melhoria das condições de habitar a cidade.

\subsection{As propostas e os projetos das crianças}

As crianças são capazes de intervir, expressando opiniões e fazendo propostas a respeito de todos os problemas da cidade, porque elas também ali vivem, como cada cidadão, e ali vivem a partir de seu próprio ponto de vista particular que é, ao mesmo tempo, mais 'baixo' e mais ignorado do que dos outros. (TONUCCI, 2005, p.20-21)

Durante o desenvolvimento das atividades e oficinas com as crianças, desde 0 início elas demostraram suas capacidades de análise e proposições quanto ao assunto a ser explorado: a cidade.

Logo no primeiro encontro, que teve como proposta uma conversa para apresentação da pesquisadora, da temática e das intenções das oficinas a serem 
realizadas, as crianças expuseram seus imaginários e experiências urbanas, trazendo suas percepções e preferências, que confrontaram e denunciaram insatisfações com o contexto no qual estão inseridas.

Diante de uma realidade de deslocamentos infantis, sobretudo nas áreas mais periféricas, tal qual observado no Jaraguá, onde muitos de seus habitantes vêm de diversas partes do Brasil, é importante destacar a existência de múltiplas infâncias construídas nesses cenários. "Grande parcela das crianças carrega em suas experiências de vida as vivências em diferentes espaços, isto é, em diferentes realidades socioeconômicas e culturais" (DEMARTINI, 2011, p.12), fato esse que reflete em suas percepções e relações criadas com e no urbano.

Durante a primeira oficina, ao visualizarem uma fotografia da região central do Município de São Paulo, as crianças fizeram comparações com os seus espaços cotidianos: "No Centro de São Paulo tem prédios e tem lojas"; expondo suas críticas através de recordações vividas naquele local: "o Centro de São Paulo fede!"

\section{FIGURA 84}

Vista do centro de São Paulo a partir do Edifício Copan, fotografia utilizada na Oficina 01.

Fonte: Arquivo pessoal, 2007

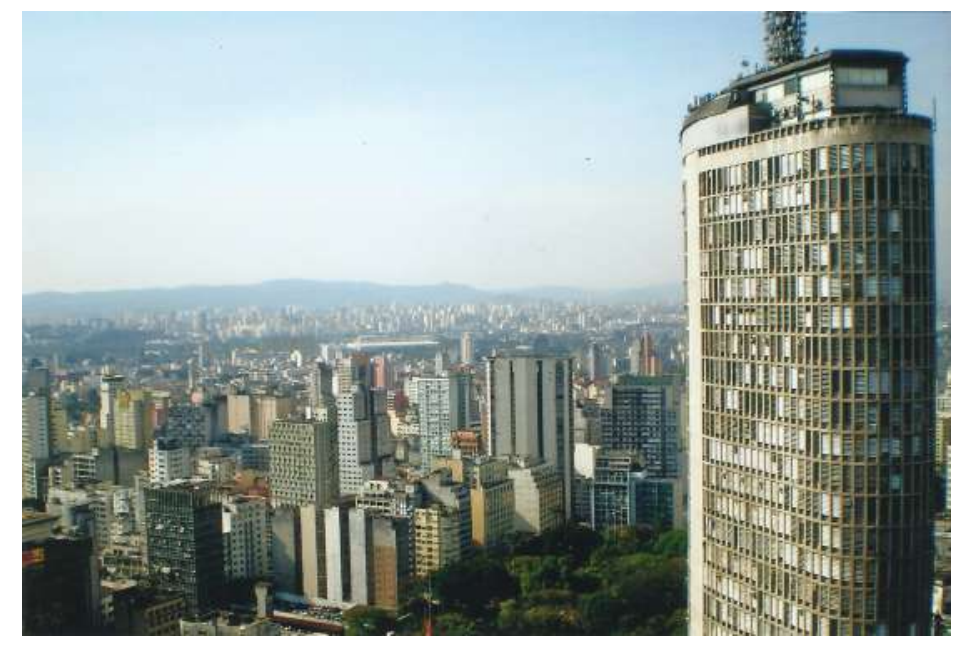


Ao entrarem em contato com outra fotografia, de São Luiz do Paraitinga, no interior paulista, novamente as recordações e as comparações com suas experiências urbanas viveram à tona: "Parece a cidade do interior onde meu pai morava". As manifestações de desejos por morar naquele local também não demoraram a surgir: "Eu moraria nessa cidade, porque ela é mais bonita, colorida e com praça". As crianças identificaram naquela imagem um padrão de cidade na qual as possibilidades de moradia talvez estivessem mais próximas de seus ideais de espaços urbanos adequados para viver.

\section{FIGURA 85}

Praça Euclides da Cunha, em São Luiz do Paraitinga, fotografia utilizada na Oficina 01.

Fonte: Arquivo pessoal, 2010.

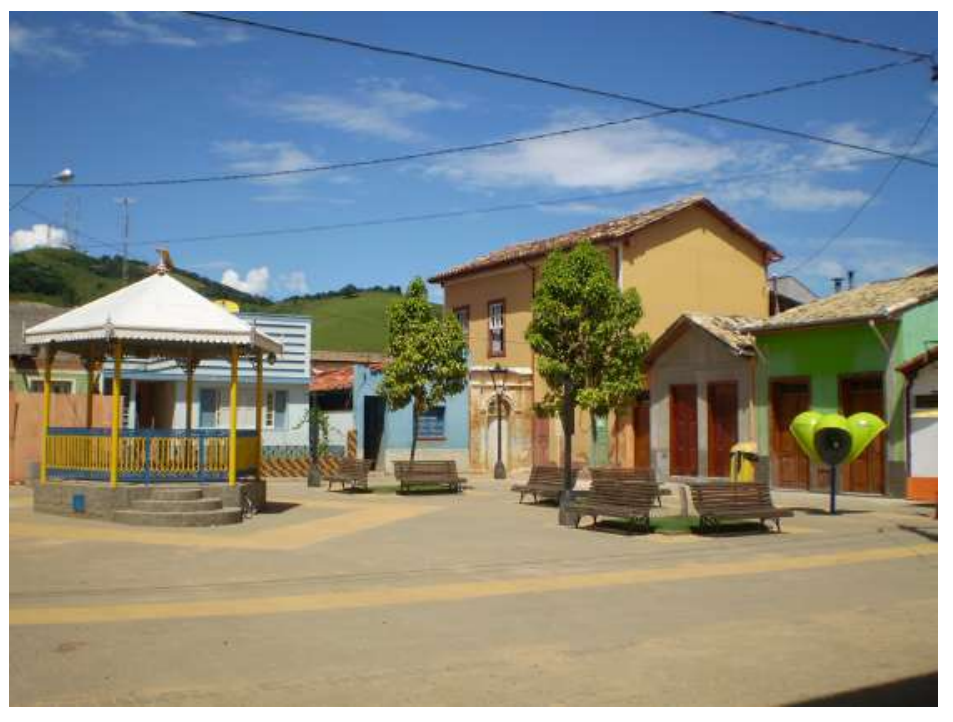

Nas falas infantis podemos identificar uma postura de insatisfação e um olhar crítico sobre os lugares onde moram, apontando aspectos que não correspondem aos seus desejos e indicando características que consideram importantes para uma cidade adequada à moradia. A região central do Município, por exemplo, não apareceu como um lugar onde as crianças gostariam de morar, tanto pelo fato de, possivelmente, nunca terem vivido essa experiência, utilizando-se dessa área apenas pelos seus serviços e equipamentos, quanto pelas memórias não muito agradáveis associadas ao local, como o mau cheiro, recordado por um dos meninos. 
Ouvir as colocações e trabalhar os desejos a partir das manifestações infantis traz uma importante contribuição para a construção de visibilidade dentro dos espaços considerados de exclusividade dos adultos. A consideração das percepções e da participação das crianças na temática urbana contribui para a mudança do senso comum associado à ideia de impotência infantil, fomentando o conhecimento de seus direitos enquanto cidadãos do presente.

Os projetos para a cidade foram trabalhados diretamente em duas oficinas com as temáticas: 'desenhar o que você gostaria que tivesse em seu bairro' e 'um dia de arquitetos: o que vocês gostariam de construir na cidade', nas quais as crianças, a partir de suas vivências e interpretações, trouxeram uma variedade de leituras dos problemas e formularam propostas para os espaços urbanos. Além destas, na última oficina realizada, na qual foram feitos pedidos ao prefeito, identificou-se o apontamento de vários pontos referentes às carências urbanas observadas em seus contextos sociais, não se limitando apenas ao ambiente construído, mas também às posturas políticas adotadas, que não atingem a todos.

Tonucci (2005) nos alerta para uma cautela na interpretação das propostas infantis, pois, podem ser vistas, em um primeiro momento, como banais e simples, sem uma leitura cuidadosa das entrelinhas. Quando um pedido de lugar para brincar surge na fala de uma criança, por exemplo, ela não está solicitando apenas que seu direito à brincadeira seja considerado e que se transforme uma área para o lazer; por trás dessa fala há uma leitura da cidade onde foram perdidos espaços para automóveis e outros interesses - políticos, econômicos...- priorizando questões que prejudicam à vivência humana nos nesses locais.

Interpretar as proposições manifestadas pelas crianças das mais múltiplas formas é entender que elas situam-se social e culturalmente em contextos diversos e, em função disso e de suas vivências, identificam-se e propõem soluções que são distintas daquelas vindas da visão adulta. Interpretar, nesse sentido 
[...] é também um trabalho de mediação com o Outro, que se relaciona com o pesquisador e com ele mantém uma relação de confiança perante aquilo que procura explicar. Interpretar as ações das crianças deverá ser feito tendo em conta um contexto histórico, social e temporal específico, muitas vezes contendo elementos que constrangem as suas ações e interpretações. Nelas, o desafio é o de tentar manter-se fiel às realidades observadas, às suas explicações ao enquadramento [...] (TREVISAN, 2015, p.146)

A partir desse entendimento, cabe também uma reflexão sobre o papel do arquiteto ao desenvolver processos participativos com crianças ou adultos. A participação coletiva, desde as simples consultas até um envolvimento mais amplo e profundo nas várias etapas propositivas, conta com diferentes pontos de vista e desejos individuais a serem debatidos e trabalhados para a elaboração de um projeto comum. 0 arquiteto, nesse cenário, não pode eliminar sua utopia ou anular suas contribuições técnicas e estéticas (PEREIRA, 2006), para construir um projeto que seja a junção de fragmentos e ideias. Faz-se necessária uma interpretação das entrelinhas dos desejos para se estabelecer um diálogo e uma sintonia entre os repertórios da arquitetura e das crianças, buscando a construção de uma identidade cultural mais ampla, que crie soluções mais adequadas e, possivelmente, mais apropriadas pelos seus usuários. No entanto, só será possível que isso ocorra, se o profissional assumir uma nova postura que incorpore subsídios vindos de dados e ações da realidade, estando aberto a propostas que possam escapar ao esperado e ao previsível (PEREIRA, 2006).

Com base nessa perspectiva de interpretação, buscamos pontuar alguns elementos observados nas propostas infantis, decorrentes das provocações colocadas pelas oficinas mencionadas anteriormente.

As propostas para espaços de múltiplos usos surgiram através de projetos em diferentes escalas: do bairro ao condomínio habitacional, passando pela qualificação das áreas públicas. Quando se propõe que o bairro comporte diferentes tipos de estabelecimentos e equipamentos - sorveteria, quadra de basquete, escolinha de futebol, zoológico, CEU, parques de diversões, circo, parque e lugares com 
Característica das cidades modernistas, que tem como base a divisão de funções dentro do espaço urbano, criando setores para abrigar determinadas funções; nosso exemplo mais próximo e mais emblemático é Brasília. brinquedos - que vão além da necessidade habitacional, podemos entender o desejo por uma cidade que não seja funcionalista ${ }^{61}$, com setorizações e o estabelecimento de áreas exclusivas para determinadas atividades. A multiplicidade de usos e funções traz um enriquecimento para a vida urbana, sobretudo para as crianças, que podem vivenciar experiências diversas, suprir suas demandas cotidianas e usufruir de espaços rotineiros com maior liberdade, estabelecendo relações mais próximas com aqueles que convivem no mesmo ambiente.

O projeto de uma área condominial como diversos equipamentos - mesas, bancos, lixos, árvores, campo de futebol, parquinho infantil, vendedor de ovos e sorvete - surge, possivelmente, pela necessidade de abrigar usos que, atualmente, a cidade não consegue acolher com a mesma segurança de algumas décadas atrás. Como já foi abordado no capítulo anterior, estes são locais onde as crianças têm possibilidades de utilização com maior liberdade, que não Ihes é permitida nos espaços livres públicos. Além disso, na proposta apresentada, as funções projetadas visam atender as demandas adultas e infantis simultaneamente, possibilitando a convivência entre as faixas etárias distintas e a constituição de aprendizado a partir do encontro com o outro.

Nos espaços livres públicos, onde surgiu a proposta da construção de um parquinho infantil, houve a preocupação com a diversidade de usos e usuários, apontando para a implantação de brinquedos e de uma área como mesa para que os adultos permaneçam enquanto aguardam as crianças em suas brincadeiras.

Para Tonucci, (2005),quando as crianças fazem propostas para os espaços de usos coletivos voltados a elas, há uma preocupação com a possibilidade desses locais serem utilizados, simultaneamente, pelos adultos, que, geralmente, estão acompanhando-as. Segundo o autor (2005, p.46), "é estranho observar que as crianças projetam espaços para todos, e os adultos acabam projetando-os para ninguém".

Outro aspecto observado se relaciona às propostas para a implantação de novos espaços livres públicos urbanos, podendo ser interpretados como uma identificação 
infantil da ausência e da demanda por esses locais em suas realidades e contextos de inserção. Além disso, tais proposições podem ser lidas na busca por autonomia, segurança e liberdade para usufruírem da cidade, potencializando os contatos com seus pares e o estabelecimento de relações de sociabilização. Os projetos de praça, parque e ciclovia surgem dentro dos desejos por lugares que sejam capazes de acolher as necessidades infantis, sem restringi-las à especialização, e na perspectiva do desenvolvimento do ser humano em contato com o mundo.

Nas oficinas realizadas antes da elaboração dos projetos para a cidade, nas quais foram retratadas atividades cotidianas, brincadeiras preferidas e os deslocamentos até a escola, os espaços livres públicos não apareceram como um cenário predominante nas apropriações autônomas infantis, apontando para uma subutilização desses locais e um controle dos adultos sobre as crianças - fato já abordado no capítulo anterior e justificado, sobretudo, pela falta de segurança apontada pelos adultos. Quando as propostas dos meninos e meninas para usos dessas áreas se dão através de diversas possibilidades, podemos interpretar que existe uma demanda latente em meio à falta de condições adequadas para o acolhimento dessas necessidades.

Tonucci (2005) defende a ideia de que o percurso de casa até a escola é uma boa oportunidade para as crianças começarem a ter autonomia nos espaços urbanos, pois estes trajetos costumam ser breves, iguais e previsíveis, possibilitando o estabelecimento de uma série de relações com seus pares e com os adultos, trazendo aliados para auxiliar no aumento da segurança ao longo do caminho. A autonomia conquistada nesses percursos pode refletir e favorecer o uso mais intenso e exploratório das demais áreas, como os parques, as praças, os equipamentos esportivos e de lazer, propostos nas elaborações infantis para seus bairros e para a cidade. 
BEATRIZ<smiles>C1#CCC=C1</smiles>

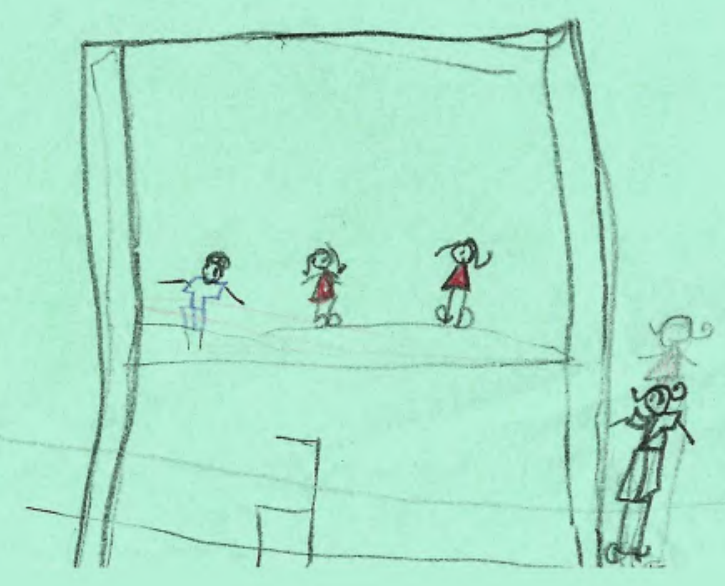




\section{FIGURA 86 [verso]}

Desenho elaborado por Beatriz. Sorveteria e pula-pula, em resposta ao questionamento sobre 'o que você gostaria que tivesse no seu bairro?' Lápis de cor e grafite sobre papel sulfite na cor verde, $210 \mathrm{~mm} \times 297 \mathrm{~mm}$, outubro de 2016.

Fonte: Arquivo pessoal, 2016 

FIGURA 87 [verso]

Desenho elaborado por Maria Eduarda. Parquinho com brinquedos e mesa, em resposta ao questionamento sobre 'o que você gostaria que tivesse no seu bairro?' Lápis de cor e grafite sobre papel sulfite na cor verde, $210 \mathrm{~mm} \times 297 \mathrm{~mm}$, outubro de 2016 .

Fonte: Arquivo pessoal, 2016. 
A presença de projetos que sugerem maior proximidade com a natureza também apareceu entre as proposições infantis através do plantio de árvores frutíferas, flores e da implantação de um parque arborizado. A necessidade de ampliação do contato com os elementos naturais, pode ser interpretada pela redução ou pelo desrespeito destes nos espaços urbanos. Na região do Jaraguá, ainda há uma forte presença de remanescentes de matas, áreas verdes e córregos abertos marcando muitos caminhos e passagens. No entanto, muitas vezes, esses elementos se encontram em estado de abandono, servindo como depósitos de esgoto, lixo e entulho, além de remeterem a situações de perigo, violência e ao uso de drogas.

Quando as crianças propõem a presença da natureza na cidade, também estão apontando para uma relação mais saudável entre ela e os usos urbanos, criando locais que possam ser apropriados com atividades que respeitem a fragilidade ambiental e possibilitem aprendizados e vivências construtivas. Além disso, é importante apontar que na visão infantil, apresentada através das proposições, não há uma oposição entre natureza e cidade, sugerindo-se a integração de maneira harmoniosa entre ambas e trazendo benefício para os moradores.

Outra proposta apontada foram os projetos de locais e equipamentos, não necessariamente públicos, com usos, muitas vezes, limitados àqueles que possuem uma disponibilidade financeira maior, como: parque de diversões, parque aquático, piscina, shopping e praia. Além de expressarem os desejos por áreas de lazer, eles denunciam situações de desigualdade social e restrição de acessos para aqueles que pertencem às camadas mais populares. Tais propostas podem ser interpretadas dentro de uma demanda por espaços de lazer diversificados, mas também como um anseio por condições econômicas e financeiras mais igualitárias, que possibilitem a todos o acesso a estes locais.

Trabalhar com a perspectiva projetiva implica adentrar o campo dos sonhos, da imaginação e dos desejos individuais e coletivos. Quando isso se revela explicitamente na forma de projetos que denunciam contrastes e desigualdades sociais, cabe uma 
atenção especial para essa interpretação, pois, ela não é o reflexo apenas da falta de condições individuais para sua concretização, mas é consequência de um sistema social e político muito mais amplo, que se forma dentro dessas desigualdades econômicas.

A partir dessa constatação, podemos acrescentar também, os pedidos feitos pelas crianças ao prefeito, nos quais a leitura das condições urbanas de seus espaços cotidianos possibilitou a identificação de carências relativas às políticas públicas de atendimento às demandas sociais, cobrando-se do administrador público melhorias de condições no tocante à habitação, educação, trabalho, limpeza e preservação urbana e áreas de lazer e cultura.

"Gostaria que os pagamentos dos prédios ficassem mais baratos."

"Melhorar os trabalhos."

"Aumentar as vagas nas escolas."

"Mais casas para os necessitados."

"Prédios."

"Quero que limpem os lixos das ruas."

"Um parquinho, um CEU e que os vereadores ajudassem."

"Arrumar os buracos das ruas."

Se as crianças identificam e indicam problemas a serem solucionados e "participam da vida da cidade com suas propostas e suas ideias, se tornarão mais responsáveis, interessadas, motivadas." (TONUCCI, 2005, p.178) Quando elas têm a possibilidade de influir nas decisões tomadas, direcionando recursos e atenção especial para aquilo que consideraram importante, sentem-se responsáveis e, portanto, com a obrigação de pensar sobre aquilo que irão pedir e projetar. A experiência de participar e intervir diretamente nas decisões urbanas colocam-nas em uma posição de importância dentro dos espaços públicos. (TONUCCI, 2005) 


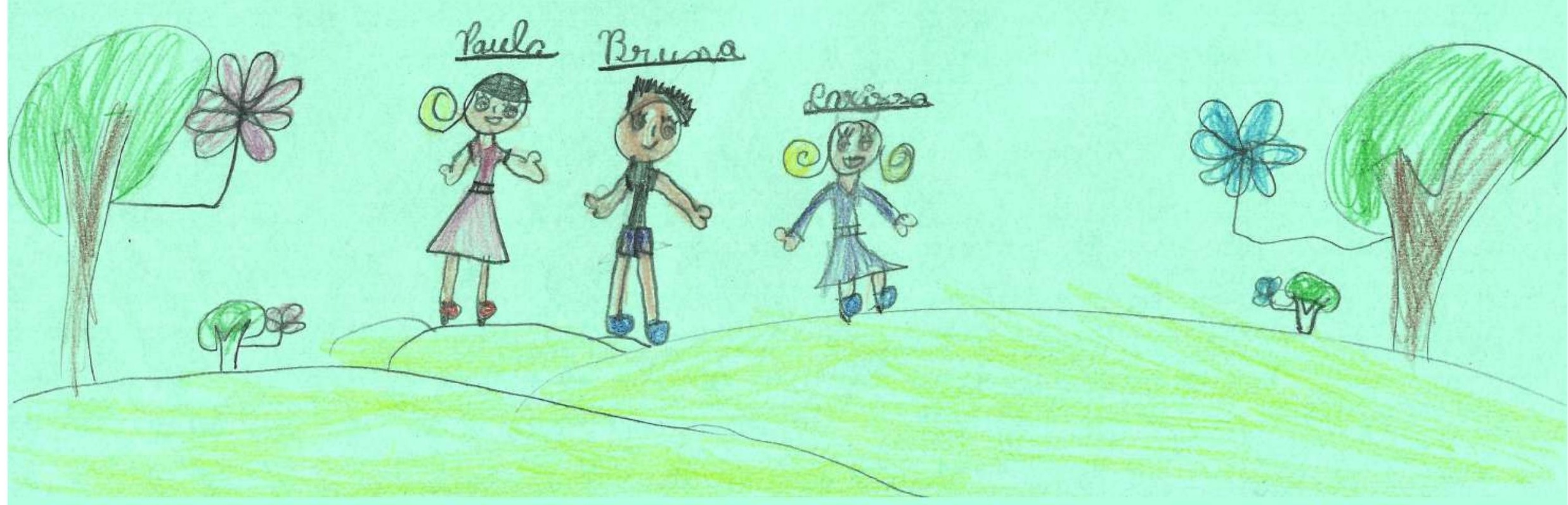


FIGURA 88 [verso]

Desenho elaborado por Maria Vitória. Parque com árvores, em resposta ao questionamento sobre 'o que você gostaria que tivesse no seu bairro?' Lápis de cor e grafite sobre papel sulfite na cor verde, $210 \mathrm{~mm} \times 297 \mathrm{~mm}$, outubro de 2016.

Fonte: Arquivo pessoal, 2016 

"Eu gostaria que plantassem árvores com coco, porque na Bahia tem árvores com coco e aqui não tem." (Lívia)

FIGURA 89 [verso]

Desenho elaborado por Lívia. Coqueiros, em resposta ao questionamento sobre 'o que você gostaria que tivesse no seu bairro?' Lápis de cor e grafite sobre papel sulfite na cor verde, $210 \mathrm{~mm} \times 297 \mathrm{~mm}$, outubro de 2016.

Fonte: Arquivo pessoal, 2016. 
Escutar significa precisar da contribuição do outro. Não basta haver interesse, motivação, convicção de que seja uma boa técnica para envolver as crianças; é preciso sentir, sincera e urgentemente, essa necessidade. É necessário precisar das crianças. Esta é a primeira e verdadeira condição para que se possa conceder a palavra às crianças: reconhecer que são capazes de dar opiniões, ideias e de fazer propostas úteis para nós, adultos [...]. Se assim for, a relação com elas será correta, entre cidadãos adultos e pequenos cidadãos, mas, agora, cidadãos. Se não for assim, [...] ficaremos sempre excluídos de seus direitos, porque elas sempre serão "futuros cidadãos" ou então "menores". (TONUCCI, 2005, p.18)

Durante o percurso de desenvolvimento das oficinas, os meninos e meninas percorreram caminhos de investigações e proposições para os espaços livres públicos de seus bairros, que, em uma escala mais ampliada, refletem propostas de alteração e mudanças para a cidade como um todo.

Ao elaborarem um estudo dos espaços cotidianos, com vistas a expressar seus desejos de melhorias para esses locais, as crianças moradoras do Jaraguá apontaram déficits no território que transcenderam a exclusividade de atendimento apenas às funções ligadas diretamente à infância. Elas identificaram problemas e mostraramse capazes de propor alterações que atingem diferentes habitantes e escalas de complexidade, demonstrando que estão atentas às questões que as rodeiam e que extrapolam os limites de seus bairros, apontando para temáticas urbanas e sociais que priorizam o atendimento aos interesses coletivos. Suas análises indicam reflexões que não se limitam apenas às soluções urbanísticas, mas relacionam-se e dependem de mudanças políticas e sociais que envolvem a cidade como um território único.

Os adultos e as crianças têm capacidades de participação semelhantes, mas com concepções, interpretações e necessidades distintas. A colaboração infantil tem importância pelo modo em que compreende as coisas e acrescenta elementos adicionais diferentes, em decorrência da sua especificidade e das relações intergeracionais com os mais velhos (SARMENTO; FERNANDES; TOMÁS, 2007). Divergentes também são as propostas elaboradas a partir das leituras da cidade: os adultos são mais conformados 
e até pessimistas em determinadas situações, enquanto as crianças enxergam possibilidades, muitas vezes mais simples, para enfrentar os problemas e sempre estão dispostas e desejosas a buscar a mudança. (TONUCCI, 2009)

As crianças são sujeitos competentes e atentos aos seus contextos de inserção, têm direito à participação e a serem ouvidas em suas necessidades e propostas. Elas são capazes de representar, em suas demandas, as carências de todos aqueles - idosos, incapazes, pobres, estrangeiros e enfermos - que não são os cidadãos tidos como parâmetros na construção da cidade (homens adultos trabalhadores e proprietários de automóveis). (TONUCCI, 2009)

Dar a cidade às crianças, e não somente serviços, assistência, controles, pode ser um bom investimento: elas devolverão uma cidade melhor. Melhor porque, se o envolvimento for real e não fictício, as crianças procurarão tornar a cidade adequada a suas necessidades; para fazer isso, serão obrigadas a torná-la melhor. Precisarão tornála propriedade de todos, a fim de que seja delas também. (TONUCCl, 2005, p.188)

\subsection{Como as crianças podem participar dos espaços públicos urbanos?}

[...] para realizar participação, é preciso encarar o poder de frente, partir dele, e então abrir os espaços de participação, numa construção arduamente conquistada, centímetro por centímetro, para que também não se recue nenhum centímetro. Participação, por conseguinte, não é ausência, superação, eliminação do poder, mas outra forma de poder. (DEMO, 2001, p.20 apud PEREIRA, 2006, p.56)

Diante das atividades propostas pelas oficinas desenvolvidas por essa pesquisa, assim como em outros trabalhos realizados com crianças, que as colocam como sujeitos de direitos, cidadãs e atores sociais de transformação, é necessário um olhar atento para não se constituir como um fim em si próprias, mas possibilitar que aberturas para as relações com os adultos sejam viabilizadas, ampliando a participação 
62 WYNESS, Michael. Childhood and society: An introduction to the sociology of childhood. London: Palgrave Macmillan, 2006.

${ }^{63}$ JAMES, Allison. Giving voice to children's voices: Practices and problems, pitfalls and potentials. American Anthropologist, v. 109, p.261-272, 2007. infantil nos espaços públicos. "Assim, dar voz às crianças não é somente deixá-las falar, mas é buscar maneiras de compreender as teorizações sobre o mundo social que as perspectivas das crianças podem nos fornecer." (WYNESS, 2006²; JAMES, $2007^{63}$ apud OLIVEIRA, 2017, p.165).

Uma participação democrática não visa apenas condensar um grande número de participantes, mas sim a diversidade de visões e propostas, muitas vezes contrastantes, que ela é capaz de contemplar. (PEREIRA, 2006)

Nessa perspectiva serão apresentadas, na sequência, duas experiências desenvolvidas pelo Laboratório A Cidade das Crianças, que realiza ações com meninos e meninas em algumas cidades, sobretudo europeias, que fazem parte dessa rede, em que as crianças são colocadas como agentes no processo de discussão e construção urbana, tornando-se aliadas privilegiadas na elaboração das mudanças.

O Laboratório é um instrumento com finalidade política presente dentro do projeto A Cidade das Crianças, que surge em Fano, na Itália, em 1991. Desde o início, sua motivação dá-se na recusa de constituir-se como um projeto educacional ou de suporte para as crianças, desenvolvendo-se com base na proposta de organização de uma nova forma de governar a cidade, tendo meninos e meninas como parâmetros e estabelecendo relações transversais e de envolvimento com todos os setores da administração pública.

A composição do Laboratório é feita por um grupo de operadores adultos que trabalham organizando e acompanhando as iniciativas infantis com propostas de transformação da cidade. Estes operadores também assumem um papel de articulação junto aos assessores e setores da administração pública, buscando-se a manutenção do compromisso assumido e tornando "operacional a decisão de aceitar a criança como parâmetro de avaliação, de projetação e de mudança da cidade." (TONUCCI, 2005, p. 149)

O Laboratório deverá assumir a função prioritária de 'grilo falante' do Pinóquio, de consciência do prefeito e da comissão de governo, protestando cada vez que não se cumpre o compromisso assumido [...] 
Abrir o Laboratório quer dizer, portanto, aceitar um conflito permanente porque o contraste entre a criança e o adulto não terminará nunca, se moverá sempre um pouco mais adiante.

Esse conflito é, no entanto, estimulante, de grande riqueza e de um debate político de alto nível, por ser real, concreto, distante dos jargões políticos televisivos. Trata-se de considerar a cidade como um laboratório, um lugar de investigação, onde se está disposto a modificar profundamente a ótica, as perspectivas, os objetivos. (TONUCCI, 2015, p.57-58, tradução nossa)

As prerrogativas do Laboratório compreendem que para que a participação infantil seja realmente considerada, ela deve assumir um papel protagonista, utilizandose de formas, procedimentos e espaços adequados para a sua expressão; devem considerar as culturas das infâncias e não reproduzir as práticas e os modelos criados pelos adultos. É responsabilidade também do Laboratório auxiliar nos processos para se livrarem dos estereótipos, das respostas óbvias e triviais vindas de colocações adultas e da mídia, que prejudicam o desenvolvimento dos desejos e da criatividade infantil. "É necessário estimular as crianças a ousarem, a desejarem, a inventarem e, então, surgirão suas ideias, suas propostas, suas contribuições." (TONUCCI, 2015, p.60, tradução nossa)

Com base nessas diretrizes, nascem as experiências do Conselho das Crianças e da Projetação Participada, que serão apresentadas a seguir. Nelas,

o adulto acolhe as indicações das crianças e as leva em consideração, tanto para modificar seus comportamentos quanto para intervir nas estruturas da cidade. Essa atitude acolhedora constrói autoconfiança nos pequenos em sua relação com os adultos, o que poderá produzir importantes resultados para uns e para outros, e também para a cidade. (TONUCCl, 2005, p.150) 


\subsection{Consellho das Crianças}

O Conselho das Crianças, como um órgão consultivo dentro do Laboratório A Cidade das Crianças, é composto e representado por meninos e meninas de diferentes idades que 'dão conselhos' aos adultos e oferecem aos administradores públicos as percepções infantis para as temáticas apresentadas pela cidade. Não se trata de uma reprodução dos conselhos municipais em miniatura, mas de uma oportunidade de entrar em contato com o ponto de vista e o conhecimento das crianças para pensar em questões colocadas pelo espaço urbano.

O surgimento do Conselho das Crianças se dá, desde os primeiros anos do projeto, com a necessidade da presença infantil junto ao prefeito de Fano para trabalhar as propostas a serem desenvolvidas para a cidade. A escolha dos conselheiros é realizada através de uma seleção de um menino e uma menina em cada escola do município, que pode ser feita através de eleição, sorteio, candidatura voluntária ou outro sistema. As crianças têm um mandato de dois anos, coincidindo, preferencialmente, com o quarto e o quinto ano da escola primária (equivalentes ao quarto e ao quinto ano do Ensino Fundamental I, no caso brasileiro), com idades entre oito e dez anos. Os conselheiros são representantes e têm a função de reunir-se com os demais estudantes para debater os pontos discutidos no Conselho e passar os apontamentos feitos durante as reuniões, bem como levar essas colocações para os encontros do Conselho.

Para o desenvolvimento das atividades do Conselho, seus membros se reúnem mensalmente na sede do Laboratório a fim de discutir os problemas que consideram não-resolvidos ou mal-resolvidos na cidade. Inicialmente, a opinião de cada um, e daqueles que ele representa, é considerada individualmente para a discussão e a constituição de um pensamento coletivo, buscando atender as diversidades presentes em suas visões e os pontos consentidos por todos os conselheiros. Os temas trabalhados partem dos problemas que são colocados pelo Laboratório, que decorrem de uma demanda vinda da administração pública ou dos próprios apontamentos das crianças. (TONUCCI, 2005, 2015) 
A fim de levar as propostas, os pedidos e as análises para uma instância de políticas públicas, pelo menos uma vez ao ano, são escolhidos conselheiros representantes para se reunirem com o Conselho ou a Câmara Municipal. Antes desse encontro, os meninos e meninas reúnem-se nas escolas e no Conselho das Crianças, para debater e escolher os pontos e os problemas que serão expostos aos administradores públicos.

Dentro das atribuições do Conselho estão temas relacionados ao cotidiano urbano e aquilo que as crianças julgam importante discutir que afetam diretamente suas realidades. Apesar das funções do Conselho não se restringirem exclusivamente às proposições e não terem a finalidade de elaborar projetos urbanísticos para intervenção nos espaços da cidade, isso pode acontecer.

As crianças pertencentes ao Conselho de Fano declararam que o Conselho:

"Serve para ajudar as crianças a expor suas opiniões"

"É importante para aqueles que têm menos poder como as crianças e serve para ajudá-las a fazer com que suas propostas tornem-se realidade"

"Serve para organizar algumas propostas para melhorar a nossa cidade"

"Permite que a cidade não sirva apenas para os adultos, mas também para as crianças"

"Para encontrar-se em uma sociedade melhor desde pequenos"

"É importante porque faz logo compreender que precisa intervir conjuntamente para melhorá-la." (TONUCCl, 2005, p.187)

Através da participação no Conselho, os meninos e meninas acabam se envolvendo, desde cedo, com as propostas de construção e de transformação da cidade. Com isso, há um conhecimento de seus direitos e da necessidade de intervenção e participação coletiva nos debates para modificação do espaço urbano, que pode refletir diretamente no exercício da cidadania durante a adolescência e a fase adulta. Quando 
isso acontece, os adultos e a administração pública reconhecem a importância desse processo, valorizando-o cada vez mais.

\subsubsection{Projetação Participada ${ }^{64}$}

Dentro do Laboratório A Cidade das Crianças, outra forma de participação infantil faz-se através da elaboração de projetos urbanos elaborados conjuntamente com profissionais da área. Semelhante à experiência do Conselho, a Projetação Participada, que teve início em 1992, também em Fano, constitui-se por um grupo de crianças que trabalham com adultos - arquitetos, urbanistas, pedagogos, psicólogos, sociólogos ou outros profissionais - que estejam dispostos a promover mudanças na cidade de maneira inovadora. Porém, enquanto o Conselho tem um papel muito mais político, voltando-se para 'dar conselhos' aos administradores públicos, a Projetação Participada tem por objetivo a prática e a proposição de soluções voltadas para atender pedidos específicos dos administradores públicos para modificar um espaço, repensar um serviço ou resolver um problema.

O desenvolvimento das atividades de Projetação Participada, geralmente, se faz em ambientes escolares, trabalhando-se com grupos de crianças separados em suas classes. No entanto, isso não é uma regra, podendo-se realizar encontros fora das escolas e com diversidade etária bastante grande dentro de cada grupo. Nessa organização os meninos e meninas sempre estão acompanhados por adultos, principalmente arquitetos e educadores, mas não exclusivamente, que irão expor a questão a ser trabalhada, permitindo que sejam examinados os aspectos que a envolvam para a elaboração de uma proposta em cima de suas análises. Após essa

${ }^{64}$ 'Projetação Participada' é a tradução para Progettazione Partecipata, adotada por Alba Olmi, no livro Quando as crianças dizem agora Chega!, de Francesco Tonucci, que foi utilizado como referência para essa pesquisa. No entanto, no campo da arquitetura esse termo também pode ser entendido e traduzido como 'Processo Participativo'. etapa, ocorre a apresentação dos materiais produzidos aos administradores públicos, que se comprometem em viabilizar sua implantação. A participação infantil não se encerra com a entrega dos projetos, mantem-se ao longo de sua concretização, funcionando como referência à qual as informações devem ser passadas e debatidas, caso ocorram imprevistos ou problemas que inviabilizem a conclusão da execução do projeto. 
Ao solicitar que as crianças proponham soluções para a cidade, não se está passando a responsabilidade do projeto para elas, mas possibilitando que participem e contribuam, permitindo aos adultos que conheçam suas propostas e ideias. Essa perspectiva vai na linha de elaboração de projetos arquitetônicos participativos, nos quais solicita-se a contribuição dos usuários para definições de características e programas a serem adotados em obras públicas.

Na Projetação Participada, a participação faz-se, sobretudo, através de desenhos e maquetes, os quais demonstram desejos e soluções para uma determinada situação. No entanto, tal manifestação merece ser tratada com respeito e atenção, permitindo que as crianças expressem-se livremente, deixando os estereótipos de lado, estimulando a criatividade e as fantasias. Segundo Tonucci $(2015$, p.62, tradução nossa), "mesmo o projeto mais fantasioso pode ajudar um adulto atento e interessado em conhecer o pensamento infantil e, através dele, encontrar soluções novas, mais bonitas e democráticas."

Possibilitar a participação das crianças não significa apenas ouvi-las, mas criar mecanismos e oportunidades para que elas se manifestem e para que os adultos possam compreender suas perspectivas e contribuições para a transformação do mundo. Isso significa repensar e modificar, sobretudo, as práticas de administração pública.

Em Fano, por exemplo, a partir de um apontamento e de uma proposta apresentada pela Projetação Participada, ocorreu a mudança da sinalização turística da cidade. Anteriormente, esta era fixada em hastes que ficavam fora do alcance de visão das crianças; a partir do projeto elaborado, a sinalização passou a ser colocada na altura delas. 0 deslocamento da sinalização não reduziu o uso por parte dos adultos, mas, ao contrário, passou a acolher também as necessidades daqueles com menor estatura, cadeirantes e crianças (TONUCCI, 2005).

A partir destes dois exemplos concretos de participação infantil nos cenários urbanos, podemos refletir sobre processos que atuam na perspectiva da criança 
${ }^{65}$ LANSDOWN, Gerison. Promoting children's participation in democratic decision-making. Italy: Arti Grafiche Ticci, 2001.

${ }^{66}$ ALFAGEME, Erika; CANTOS, Raquel; MARTÍNEZ, Marta. De la participación al protagonismo infantil: Propuestas para la acción. Madrid: Plataforma de Organizaciones de Infancia, 2003. investigadora e propositiva, tal qual foi trabalhada nas oficinas desenvolvidas por essa pesquisa. Cabe pensar, no entanto, que as experiências apresentadas anteriormente foram realizadas em situações e escalas muito mais reduzidas do que aquelas colocadas por uma cidade metropolitana, que tem seus problemas potencializados. Em São Paulo, por exemplo, seria inviável a implantação de apenas um Conselho das Crianças para englobar toda a diversidade de questões que surgem dentro de cada região. Nesse caso, talvez, fosse mais prudente optar por vários Conselhos dentro de divisões como as Prefeituras Regionais ou as Diretorias Regionais de Ensino, que abordam um número limitado de escolas dentro de um limite territorial.

O objetivo dessa pesquisa não é propor uma solução única ou defender os projetos realizados pelo Laboratório A Cidade das Crianças para viabilizar a participação infantil na cidade. Mas, ao apresentarmos as duas experiências realizadas por esse projeto, estamos trazendo elementos que confirmam e comprovam a possibilidade da atuação das crianças dentro dos espaços públicos urbanos, desde que exista um entendimento e aceitação delas enquanto sujeito e cidadãs de direitos e um desejo pela transformação em uma sociedade mais democrática.

Considerar a criança por esse viés possibilitará o desenvolvimento de suas novas habilidades; contribuirá com a constituição de uma autoestima mais positiva; mudará o senso comum associado à ideia de impotência; reconhecerá a capacidade da criança de assumir responsabilidades individuais e sociais; fomentará o conhecimento acerca de seus direitos; possibilitará a elas que reclamem seus próprios direitos; permitirá, também, que influenciem os processos de transformação social e se constituírem como uma forma de empoderamento. (LANSDOWN, 200165; ALFAGEME; CANTOS; MARTÍNEZ, 2003 ${ }^{66}$, apud OLIVEIRA, 2017, p.165).

Ao proporcionar e incentivar a participação de meninos e meninas, sobretudo aqueles moradores de áreas mais carentes e periféricas, em processos em que foram excluídos historicamente e desconsiderados como atores sociais e cidadãos, estamos propondo uma forma diferente de pensar o planejamento urbano e o estabelecimento de políticas públicas, visando a constituição de uma participação democrática. Quando 
falamos em empoderamento infantil em relação aos espaços da cidade, pressupõem-se que as crianças participem dos projetos que estão diretamente relacionados com elas, podendo se expressar e apontar alterações que julgarem importantes e necessárias, sem serem desqualificadas e desprezadas enquanto sua condição atual.

As oficinas que se desenvolveram dentro da temática de transformação da cidade a partir dos desejos infantis, trouxeram uma riqueza de propostas com apropriações e usos para os espaços urbanos, com reflexo social, decorrentes das leituras dos contextos em que as crianças estão inseridas. Elas mostraram-se sensíveis não apenas as construções de novos equipamentos, mas também identificaram carências e déficits provenientes do descaso das políticas públicas com as áreas periféricas, aparecendo desejos de qualificação dos espaços públicos existentes e do atendimento às condições sociais de educação, habitação e trabalho.

"Os projetos envolvendo as crianças e seus contextos de vida contribuem para a consideração delas como cidadãs ativas e competentes e nos mostram que essas estão bastante atentas ao espaço que as rodeia." (OLIVEIRA, 2017, p.174-175)

A importância em trabalhar os desejos infantis para a cidade também diz respeito ao direito que lhes é (ou não) conferido como uma forma de participação na construção urbana. No entanto, o grande desafio se dá em como realizar e concretizar as propostas para atuação infantil em nossa realidade social, política e cultural, que requer a transformação da cidade como um todo, desde as políticas públicas, passando pelas práticas de produção desse território, até a mudança individual de valorização da criança. Acredita-se que, com essa transformação, o espaço urbano possa tornar-se mais democrático em sua construção e utilização.

O contato com as crianças, proporcionado pela realização das oficinas, abriu novos horizontes e desafios em trabalhar, no campo da arquitetura e do urbanismo, com as demandas e as questões levantadas a partir do ponto de vista infantil. Diante disso, surgem inúmeras inquietações a fim de aproximar esses dois universos, hoje, bastante distantes: Como incorporar os desejos, as fantasias e as manifestações lúdicas das 
crianças para construir da cidade? Como trabalhar o olhar 'inocente', porém conectado com a realidade que o cerca, diante de uma produção perversa da cidade, que produz a segregação urbana? O arquiteto está preparado para interagir com a criança, enquanto interlocutora? 


\section{CONSIDERAÇÕES FINAIS}

Eu não queria ocupar o meu tempo usando palavras bichadas de costume.

Eu queria mesmo desver o mundo.

Manoel de Barros ${ }^{67}$

${ }^{67}$ BARROS, Manuel. Menino do mato. $1^{\text {a }}$ ed. Rio de Janeiro: Objetiva/ Alfaguara, 2015. 

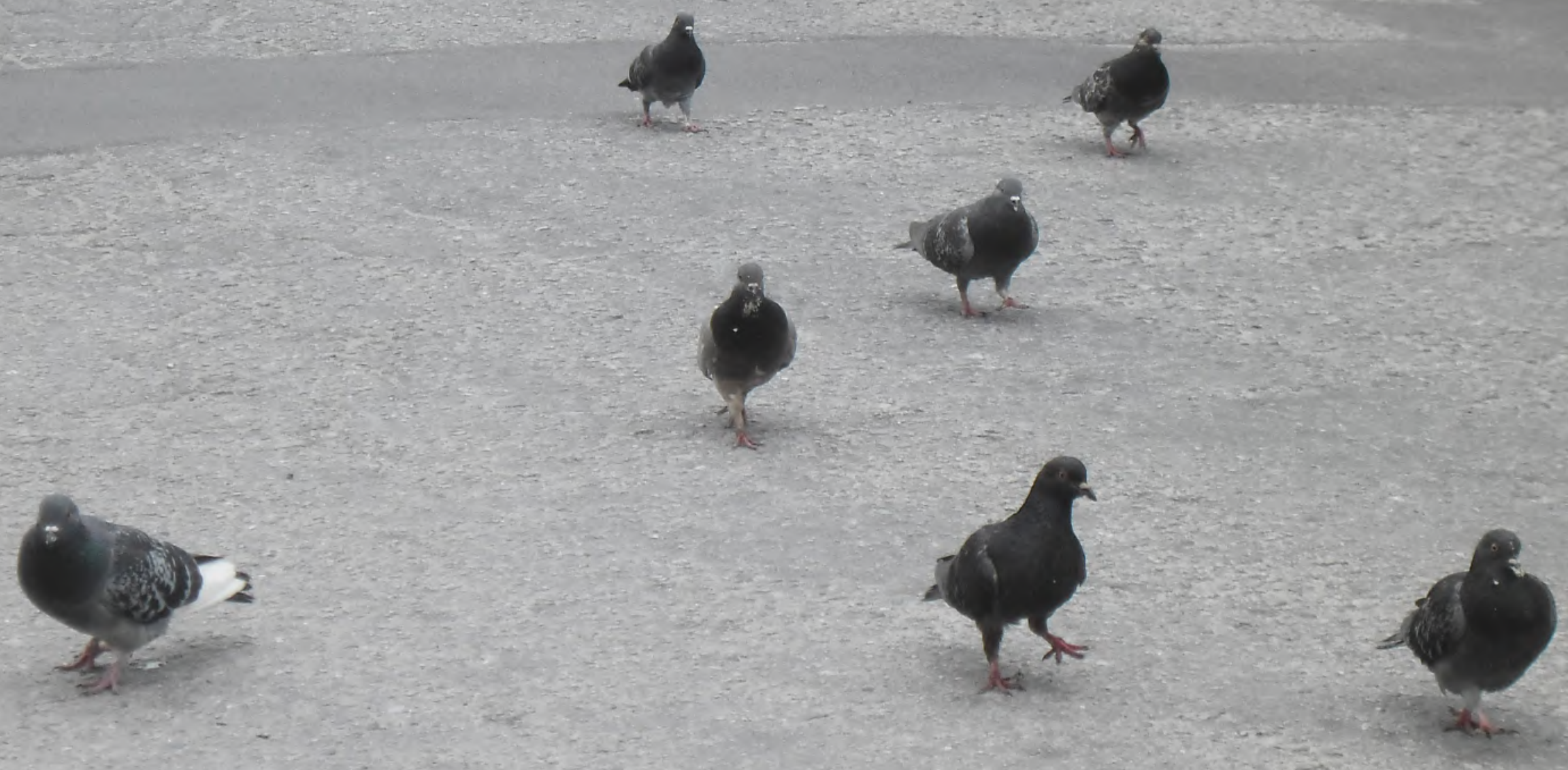
FIGURA 90 [verso]

Fotografia feita pelo grupo de Maria Eduarda, Nicolly e Yasmin durante visita ao entorno da escola. Máquina fotográfica digital, setembro de 2016.

Fonte: Arquivo pessoal, 2016 
O campo de ação do arquiteto, nas condições do mundo contemporâneo, amplia-se cada vez mais. Não se trata de uma avaliação quantitativa - mais casas, mais cidades, mais serviços necessários. Seria afirmar o óbvio. Meu ponto de vista é o da estética. E, melhor dito, significaria: as artes ganham, cada vez mais, raízes novas na vida social. 0 campo especulativo das artes se amplia. Seu interesse pela universalidade dos objetos, alguns deles tradicionalmente afastados das especulações estéticas, mostra o homem através da arte explorando e modificando o mundo físico e social com novos instrumentos. (ARTIGAS, 2004, p.108, grifo nosso)

Nessa perspectiva, entendendo o papel social da arquitetura, do urbanismo e do paisagismo como elementos que se inserem na multiplicidade e na complexidade dos temas urbanos ligados à infância, a presente pesquisa desenvolveu-se no intuito de conhecer os espaços urbanos de um contexto periférico paulistano a partir das leituras e das interpretações de um de seus moradores mais 'invisíveis', as crianças.

Colocá-las como sujeitos da pesquisa e atores sociais, reconhecendo seus direitos de cidadãs, implicou em uma investigação aberta às suas contribuições e visões distintas daquelas vindas de um ponto de vista adulto. A experiência e o contato com as crianças durante as oficinas realizadas, bem como as respostas e produções infantis decorrentes delas, revelaram possibilidades de refletir sobre o papel do arquiteto, não como um artista ou um gênio que projeta, em sua solidão, os espaços a serem utilizados coletivamente, mas como um profissional que deve estar, cada vez mais, integrado e conectado aos contextos sociais e atento às demandas que surgem desses cenários.

Considerar e respeitar a visão da criança como uma manifestação do universo infantil e não querer colocá-la dentro dos padrões e expectativas dos adultos foi um ponto crucial trabalhado durante as atividades propostas pela pesquisa. Entender como elas podem ser protagonistas de processos de mudanças dentro da cidade, implica também em compreender como elas são vistas pelos adultos - pais, professores, administradores públicos - e buscar reconhecê-las dentro de uma responsabilidade 
coletiva e social.

O direito das crianças à cidade, assim como também é para o adulto, vai além do acesso aos equipamentos públicos que esse espaço pode oferecer; é um direito de participar de sua transformação para atender as necessidades coletivas e tornála mais democrática em seus usos. Dessa forma, independentemente da condição social ou da faixa etária a qual pertençam, todos os cidadãos têm o direito de serem escutados e respeitados em suas demandas, deixando seus papéis de consumidores dos espaços urbanos, para tornarem-se agentes. Não são apenas as crianças que são desconsideradas nestes processos, mas, para elas isso torna-se ainda mais latente, pois, estão excluídas dos meios de decisões e necessitam de estruturas 'adaptadas' para que sua participação possa se efetivar.

Apesar do enfoque dessa pesquisa estar centrado nas crianças maiores de seis anos de idade, buscando o reconhecimento delas enquanto sujeitos de participação e agentes dentro da cidade, identifica-se uma carência, ainda maior, de políticas e espaços públicos que acolham e favoreçam as manifestações de crianças e bebês pertencentes a uma faixa etária ainda menor. A Primeira Infância ${ }^{68}$, como é classificada essa fase que compreende desde o nascimento até os seis primeiros anos de vida, encontra-se em situação de maior invisibilidade, não permitindo a participação de seus sujeitos em reflexões e questões que lhes digam respeito.

Os pontos aqui investigados não excluem as crianças na Primeira Infância, porém, necessitam de adaptações e apropriações, tendo em vista a presença de necessidades diferentes quanto às formas de abordagem para permitir suas manifestações e interpretações a fim de elaborar um novo projeto de cidade que as integre.

Partindo-se do objetivo de investigar a relação das crianças com os espaços livres urbanos, a pesquisa reafirmou-se e redefiniu-se diante dos apontamentos e manifestações elaborados durante as atividades realizadas nas oficinas pelos meninos e meninas moradores do Jaraguá. As leituras dos espaços cotídiefiniøã̃o Łeita pela Lei № 13.257, de 8 de março de 2016. 
as questões colocadas por esse território foram apontadas através de expressões infantis, permitindo que a pesquisa também se colocasse aberta a ser construída pelas crianças. Dessa forma, a estrutura e os conteúdos trabalhados foram completamente afetados por essa experiência.

Inicialmente, foi feita uma reflexão teórica apontando os conceitos que embasaram as discussões que foram trabalhadas a partir das colocações infantis. Essa etapa apresentou-se de grande importância para o entendimento de todo o trabalho, pois, ofereceu as bases nas quais apoiamo-nos para o entendimento e o desenvolvimento das reflexões sobre crianças e cidades, que são trabalhados ao longo da pesquisa.

A partir do segundo capítulo, a experiência com as crianças do Jaraguá tornouse determinante na construção e na condução das reflexões sobre seus papéis sociais e políticos dentro dos espaços e da esfera de vida pública. Através da identificação de possibilidades de leituras do território, foi permitido entrar em contato com a construção e a caracterização da cidade periférica dentro da cidade 'formal'. Pode-se dizer que o apontamento das cinco possíveis linhas de interpretação desse território leitura das desigualdades; do lazer, do consumo e da inserção social; dos espaços das infâncias urbanas; dos espaços públicos versus privados; e dos afetos e identidades - permitiram a visualização de um território múltiplo e diverso dentro da visão infantil, na qual as carências pessoais mistura-se às coletivas e os problemas e questões extrapolam para uma escala além dos limites dos bairros de vivência.

Os desejos e projetos infantis também não se distanciaram de uma leitura múltipla e complexa da cidade. Os temas apontados indicaram que, apesar de uma suposta 'alienação' que os adultos conferem às crianças, elas estão bastante integradas e cientes das questões sociais que as envolvem, provando que são capazes de interferir e opinar de maneira consciente nesses assuntos.

A discussão sobre a participação infantil, com a identificação de possibilidades de envolver as crianças nos processos participativos de discussão e construção da 
cidade também mostrou-se de grande importância na reflexão sobre os mecanismos de reconhecimento delas como atores políticos dentro da sociedade. Essa perspectiva implica em uma modificação dos papéis infantis nos ambientes públicos e privados, considerando-as como capazes e com seus direitos respeitados, incorporando e valorizando sua participação nas politicas públicas, através da adoção de mecanismos e processos adequados para isso.

Diante das respostas apresentadas através das diferentes formas de manifestação possibilitadas pelas oficinas aqui realizadas, arriscamos dizer que as crianças são, e devem ser reconhecidas, como sujeitos conscientes de seus contextos sociais, capazes de identificar os problemas que as envolvem e sugerir ou apontar soluções para os mesmos. Portanto, são competentes para participar daquilo que se relaciona com seus cotidianos e com as questões urbanas de seu entorno, identificando, ainda, leituras possíveis para problemas complexos que envolvem estruturas políticas, econômicas, sociais e culturais relacionadas aos cenários urbanos.

Estudar a relação da criança com a cidade é, também, uma forma de estudar a cidade - atualmente excludente e com formas de produção que favorecem alguns em detrimento de outros - e de propor mudanças para a mesma, buscando cenários mais democráticos e menos desiguais.

Essa pesquisa revelou, através das diferentes formas de manifestações infantis e das respostas dadas às provocações colocadas durante as oficinas, que as crianças estão inseridas em seus espaços cotidianos urbanos, seja através do reconhecimento de sua materialidade (espaços livres, edificações e construções urbanas), seja por meio da identificação dos problemas e carências sociais observadas em seus contextos cotidianos. Vários exemplos foram apresentados, desde as leituras urbanas e pedidos ao prefeito, nos quais as carências habitacionais, de saúde, educação e desigualdades sociais foram apontadas, até a identificação de temas relacionados diretamente com as questões da infância, como os desejos por mais áreas com brinquedos. Comparadas aos adultos, as crianças mostraram-se mais abertas e dispostas a arriscar e projetar 
soluções sem a limitação de barreiras econômicas e políticas, o que permite uma variedade de propostas, abrangendo diferentes questões.

A partir dessas revelações e constatações, podemos apontar para o potencial infantil na participação urbana, visando à transformação da cidade em seus aspectos físicos e em suas políticas públicas, de modo a construir cenários mais democráticos e acessíveis aos diferentes cidadãos e demandas.

Nesse sentido, não é possível pensar em um projeto ideal único para a cidade, mas buscar uma construção mais dialógica, com espaço de trocas de conhecimentos e debates democráticos, que resultem em projetos urbanos mais apropriados e condizentes com as expectativas de seus cidadãos, incluindo aí também as crianças.

0 arquiteto, nesse cenário, assume um papel desafiador: como inserir as crianças nos processos de pensar e projetar a cidade? Como captar e trabalhar com seus repertórios projetivos ao mesmo tempo em que a linguagem técnica da arquitetura é colocada?

Eis os novos desafios a serem trabalhados pelos profissionais que se colocam, cada vez mais, preocupados em trabalhar com as questões sociais apresentadas pela arquitetura e pelo urbanismo.

Segundo Artigas (1989, p.36), a arquitetura deve ser vista "como expressão cultural de um povo, de uma época, de um período histórico, que conversa não apenas tecnicamente, mas troca com o passante sagaz um diálogo absolutamente impossível de ser destruído". Atualmente presenciamos uma arquitetura e um urbanismo que indicam que estamos em uma sociedade construída por poucos, para atender aos interesses da minoria e que, portanto, não é democrática. Desse modo, coloca-se como fundamental refletir sobre quais processos devemos adotar para atingir uma mudança desse perfil e incluir nas propostas as percepções infantis.

Acolher essas manifestações - não exclusivamente por meio de suas falas, mas também através das suas diversas formas de expressão e da observação de 
seus comportamentos - não é apenas um exercício pedagógico, mas um respeito aos seus direitos enquanto cidadãs e sujeitos capazes de interpretar a realidade, propor e transformar a cidade. Ao reconhecê-las como atores políticos e sociais, estamos propondo também uma nova forma de construir e produzir espaços urbanos, que vai na contramão de uma postura que visa atender, quase que exclusivamente, aos interesses das classes dominantes. Se pensamos e projetamos cidades ouvindo as crianças, permitindo que elas participem das mais distintas etapas desse processo, desde as concepções projetuais iniciais até formas de manutenção das propostas implantadas, seguramente os espaços urbanos se tornarão mais atrativos e democráticos para todos.

A partir dessa pesquisa, identificou-se um campo amplo de possibilidades de estudo nas relações entre as crianças e as cidades. No entanto, sem a pretensão de esgotar aqui os temas relacionados a essa complexidade, buscou-se trazer uma contribuição para novas discussões a respeito das relações infantis nos espaços urbanos a partir das visões de seus sujeitos, na intenção de que, em um futuro não muito distante, possamos integrá-las em novas formas de produzir e gerir as cidades de maneira mais democrática.

"Se nosso mundo urbano foi imaginado e feito, então ele pode ser reimaginado e refeito." (HARVEY, 2013, p.33) 


\section{REFERÊNCIAS}

\section{BIBLIOGRÁFICAS}

ALMEIDA, Elvira de. A criança e a invenção do seu espaço: a expressão lúdica como elo entre o designer e o usuário. Dissertação (mestrado) Faculdade de Arquitetura e Urbanismo da Universidade de São Paulo, FAUUSP. São Paulo, 1985.

ARIÈS, Philippe. História social da criança e da família. Tradução de Dora Flaksman. $2^{a}$ ed. Rio de Janeiro: LTC, 2006.

ARTIGAS, João Batista Vilanova. Caminhos da arquitetura. [org. José Tavares Correia de Lira, Rosa Artigas]. São Paulo: Cosac \& Naify, 2004.

ARTIGAS, João Batista Vilanova. A função social do arquiteto. São Paulo: Nobel, 1989.

ASSOCIAÇÃO INTERNACIONAL DE CIDADES EDUCADORAS (AICE). Carta das Cidades Educadoras. [Gênova, 2004]. Disponível em: <http://www.edcities.org/wp-content/ uploads/2013/10/Carta-Portugues.pdf>. Acesso em: 13 jan. 2018.

BARROS, Manuel de. Memórias inventadas - a infância. São Paulo: Planeta, 2004.

BARROS, Manuel de. Menino do mato. $1^{\text {a }}$ ed. Rio de Janeiro: Objetiva/ Alfaguara, 2015

BOUCINHAS, Caio; LIMA, Catharina Pinheiro C. S. Parque Pinheirinho d'Água: a luta por reconhecimento e visibilidade. Pós. Revista do Programa de Pós-Graduação em Arquitetura e Urbanismo da FAUUSP, São Paulo, v.20, n.33, p.11-34, 2013. Disponível em: <http://www.revistas.usp.br/posfau/article/ view/80918/84560>. Acesso em: 15 jan. 2018.

BRASIL. Constituição (1988). Constituição da República Federativa do Brasil. [recurso eletrônico]. Brasília, DF: Supremo Tribunal Federal, Secretaria de Documentação, 2017. Disponível em: <http://www.stf.jus.br/arquivo/cms/legislacaoConstituicao/anexo/CF. pdf>. Acesso em: 22 jan. 2018. 
Decreto $\mathrm{n}^{\circ} 99.710$, de 21 de novembro de 1990. Promulga a Convenção sobre os Direitos da Criança. Brasília, DF, 22 nov. 1990. Disponível em: <http://www.planalto. gov.br/ccivil_03/decreto/1990-1994/d99710.htm>. Acesso em: 22 jan. 2018.

Estatuto da criança e do adolescente (1990). Estatuto da criança e do adolescente [recurso eletrônico]. Lei n. 8.069, de 13 de julho de 1990, e legislação correlata. 15. ed. Brasília, DF: Câmara dos Deputados, 2016. Disponível em: <http:// bd.camara.gov.br/bd/ handle/bdcamara/18403>. Acesso em: 22 jan. 2018.

Lei n ${ }^{\circ}$ 9.394, de 20 de dezembro de 1996. Lei de Diretrizes e Bases da Educação Nacional (LDB). Estabelece as diretrizes e bases da educação nacional. Brasília, 20 de dezembro de 1996. Disponível em: <http://www.planalto.gov.br/ccivil_03/leis/L9394. $\mathrm{htm}>$. Acesso em: 13 jan. 2018.

Lei $\mathrm{n}^{\circ} 13.257$, de 8 de março de 2016. Dispõe sobre as políticas públicas para a primeira infância. Brasília, DF, 8 mar. 2016. Disponível em: <http://www. planalto. gov.br/ccivil_03/_ato2015-2018/2016/lei/L13257.htm>. Acesso em: 12 fev. 2018.

CALDEIRA, Teresa Pires do Rio. Cidade de muros: crime, segregação e cidadania em São Paulo. Tradução de Frank de Oliveira e Henrique Monteiro. São Paulo: Editora 34/ Edusp, 2000.

CARDOSO, Bianca Breyer. Por onde andam as crianças? Da estrutura sócio-espacial às práticas cotidianas em Porto Alegre. Dissertação (mestrado) Faculdade de Arquitetura da Universidade Federal do Rio Grande do Sul, UFRGS. Porto Alegre, 2012

CHAUÍ, Marilena. Convite à filosofia. São Paulo: Ed. Ática, 2000.

COHN, Clarice. Antropologia da criança. Rio de Janeiro: Zahar, 2005.

DARDEL, Eric. 0 Homem e a Terra: Natureza da realidade geográfica. Tradução de Vladimir Bartalini [material para uso exclusivo das disciplinas AUP 5834 - A Paisagem no Desenho do Cotidiano Urbano e AUP 5882 - Paisagem e Arte: Intervenções Contemporâneas, do Curso de Pós-Graduação da Faculdade de Arquitetura e Urbanismo da Universidade de São Paulo]. São Paulo: FAUUSP, 2013. 
DEMARTINI, Zeila de Brito Fabri. Diferentes infâncias, diferentes questões para a pesquisa. In: MARTINS FILHO, Altino José e PRADO, Patrícia Dias (orgs.). Das pesquisas com crianças à complexidade de infância. Campinas, SP. Editora Autores Associados, 2011.

DIAS, Marina Simone; FERREIRA, Bruna Ramos. Espaços públicos e infâncias urbanas: a construção de uma cidadania contemporânea. Revista Brasileira de Estudos Urbanos e Regionais, Recife, v.17, n.3, p.118-133, set.-dez. 2015. Disponível em: <http://www. anpur.org.br/revista/rbeur/index.php/rbeur>. Acesso em: 28 jan. 2018.

DONADIEU, Pierre. Para uma conservação inventiva do território. In: BERQUE, Augustin (Org.). Cinq propositions pour une théorie du paysage. Sayssel: Editions Champ Vallon, 1994. [Tradução de Vladimir Bartalini material para uso exclusivo das disciplinas AUP 5810 - Paisagismo, do Curso de Pós-Graduação da Faculdade de Arquitetura e Urbanismo da Universidade de São Paulo, $1^{\circ}$ semestre de 2012]. São Paulo: FAUUSP, 2013.

FARIA, Ana Lucia Goulart de.; DEMARTINI, Zeila de Brito Fabri; PRADO, Patrícia Dias (orgs.). Por uma cultura da infância: metodologias de pesquisa com crianças. $3^{a}$ ed. Campinas: Editora Autores Associados, 2009.

FARIAS, Rhaisa Naiade Pael; MULLER, Fernanda. A Cidade como Espaço da Infância. Educação \& Realidade, Porto Alegre, v.42, n.1, p.261-282, jan.-mar.2017. Disponível em: <http://www.scielo.br/pdf/edreal/v42n1/2175-6236-edreal-42-01-00261.pdf>. Acesso em: 14 jan. 2018.

FREIRE, Paulo. À sombra desta mangueira. São Paulo: Olho d'Água, 1995.

Pedagogia da autonomia: saberes necessários à prática educativa. $54^{\mathrm{a}} \mathrm{ed}$. Rio de Janeiro/ São Paulo: Paz e Terra, 2016.

2017a.

Pedagogia do oprimido. $64^{\mathrm{a}}$ ed. Rio de Janeiro/ São Paulo: Paz e Terra,

Política e educação. [org. Ana Maria de Araújo Freire]. $3^{a}$ ed. Rio de Janeiro/ São Paulo: Paz e Terra, 2017b. 
FRÚGOLI JR., Heitor. Os shoppings de São Paulo e a trama do urbano: um olhar antropológico. In: PINTAUDI, Silvana Maria; FRÚGOLI JR, Heitor. (Orgs) Shopping centers: espaço, cultura e modernidade nas cidades brasileiras. São Paulo: Editora da Universidade Estadual Paulista, 1992.

GADOTTI, Moacir. Cidade Educadora e Educanda. Revista Pátio, Porto Alegre, ano X, n.39, p.53-55, ago-out 2006.

Escola Cidadã frente ao "Escola Sem Partido". In: AÇÃO EDUCATIVA ASSESSORIA, PESQUISA E INFORMAÇÃO (Org.). A ideologia do movimento Escola Sem Partido: 20 autores desmontam o discurso. São Paulo: Ação Educativa, 2016.

GAETA, Antonio Carlos. Gerenciamento dos shopping centers e transformação do espaço urbano. In: PINTAUDI, Silvana Maria; FRÚGOLI JR, Heitor. (Orgs) Shopping centers: espaço, cultura e modernidade nas cidades brasileiras. São Paulo: Editora da Universidade Estadual Paulista, 1992.

GOBBI, Marcia Aparecida. Desenho infantil e oralidade: instrumentos para pesquisas com crianças pequenas. In: FARIA, Ana Lucia Goulart de.; DEMARTINI, Zeila de Brito Fabri; PRADO, Patrícia Dias (orgs.). Por uma cultura da infância: metodologias de pesquisa com crianças. $3^{\mathrm{a}}$ ed. Campinas: Editora Autores Associados, 2009.

GÓMEZ-GRANELL, Carmen; VILA, Ignacio (Orgs.). A cidade como projeto educativo. Tradução de Dayse Vaz de Moraes. Porto Alegre: Artmed, 2003.

GORELIK, Adrián. Prefácio à edição brasileira - A cidade decifrada. In: SARLO, Beatriz. A Cidade Vista: Mercadorias e cultura urbana. $1^{\text {a }}$ ed., tradução Monica Stahel. São Paulo: Editora WMF Martins Fontes, 2014.

HARVEY, David. A liberdade da cidade. Tradução Gavin Adams. In: MARICATO, Ermínia ... [et al.] Cidades rebeldes: Passe Livre e as manifestações que tomaram as ruas do Brasil. $1^{\mathrm{a}}$ ed. São Paulo: Boitempo: Carta Maior, 2013.

Cidades Rebeldes: Do direito à cidade à revolução urbana. Tradução Jeferson Camargo. São Paulo: Martins Fontes - selo Martins, 2014.

HILLMAN, James. Cidade e Alma. Tradução de Gustavo Barcellos e Lúcia Rosenberg. São Paulo: Studio Nobel, 1993. 
JACOBS, Jane. Morte e vida de grandes cidades. Tradução Carlos S. Mendes Rocha, $2^{a}$ ed. São Paulo: WMF Martins Fontes, 2011.

KOSSOY, Boris. Realidades e ficções na trama fotográfica. São Paulo: Ateliê Editorial, 2002.

LA CITTÀ DEI BAMBINI. EL PROYECTO - La ciudad. Roma, c2009. Disponível em: <www. lacittadeibambini.org>. Acesso em: 26 jul. 2017.

LEITE, Maria Isabel F.P. 0 que e como desenham as crianças? Refletindo sobre condições de produção cultural da infância. Tese (doutorado) Faculdade de Educação da Universidade Estadual de Campinas, FEUNICAMP. Campinas, 2001.

LIMA, Catharina Pinheiro C. Dos Santos. A natureza na cidade. Tese (doutorado) Faculdade de Arquitetura e Urbanismo da Universidade de São Paulo, FAUUSP. São Paulo, 1996.

LIMA, Mayumi Watanabe de Souza. A cidade e a criança. São Paulo: Studio Nobel, 1989. Nobel, 1995

Arquitetura e Educação. [coord. Sérgio de Souza Lima]. São Paulo: Studio

MAGNOLI, Miranda Martinelli. O parque no desenho urbano. Revista Paisagem e Ambiente: ensaios. São Paulo: FAUUSP, n.21, p. 199-214, 2006.

MARICATO, Ermínia. É a questão urbana, estúpido! In: MARICATO, Ermínia ... [et al.] Cidades rebeldes: Passe Livre e as manifestações que tomaram as ruas do Brasil. $1^{\text {a }}$ ed. São Paulo: Boitempo: Carta Maior, 2013.

Para entender a crise urbana. São Paulo: Editora Expressão Popular, 2015.

MARTINS FILHO, Altino José e PRADO Patrícia Dias (orgs.). Das pesquisas com crianças à complexidade de infância. Campinas: Editora Autores Associados, 2011.

MASINI, Elcie F. Salzano (org.). Perceber. raiz do conhecimento. São Paulo: Vetor, 2012.

MERLEAU-PONTY, Maurice. Fenomenologia da percepção. Tradução de Carlos Alberto Ribeiro de Moura, 4ª ed. São Paulo: WMF Martins Fontes, 2015. 
MEYER, Regina M. P.; GROSTEIN, Marta D.; BIDERMAN, Caio. São Paulo Metrópole. São Paulo: Edusp: Imprensa Oficial, 2004.

MORALES, Patricia Pèrez. A Cidade Educadora: da muralha ao diálogo. Dissertação (mestrado) Faculdade de Educação da Universidade de São Paulo, FEUSP. São Paulo, 2003.

NASCIMENTO, Andréa Zemp Santana do. A criança e o arquiteto: quem aprende com quem? Dissertação (mestrado) Faculdade de Arquitetura e Urbanismo da Universidade de São Paulo, FAUUSP. São Paulo, 2009.

OLIVEIRA, Fabiana de. Reflexões a respeito de uma experiência de participação infantil no Brasil envolvendo os espaços urbanos e a perspectiva das crianças. Revista Portuguesa de Educação, Braga, v.30, n.1, p.157-179, 2017. Disponível em: <http:// revistas.rcaap.pt/rpe/article/view/8688/9177>. Acesso em: 13 jan. 2018.

OTONDO, Catherine e GRINOVER, Marina. Apresentação. In: ROCHA, Paulo Mendes da. Maquetes de papel. São Paulo: Cosac Naify, 2007.

PADILHA, Paulo Roberto. Educar em todos os cantos: reflexões e canções por uma educação intertranscultural. São Paulo: Instituto Paulo Freire / Editora Cortez, 2007.

Município que Educa: Nova arquitetura da gestão pública. São Paulo: Editora e Livraria Instituto Paulo Freire, 2009.

PEREIRA, Raul Isidoro. O Sentido da Paisagem e a Paisagem Consentida: projetos participativos na construção do espaço livre público. Tese (doutorado) Faculdade de Arquitetura e Urbanismo da Universidade de São Paulo, FAUUSP. São Paulo, 2006.

PINTAUDI, Silvana Maria; FRÚGOLI JR, Heitor. (Orgs) Shopping centers: espaço, cultura e modernidade nas cidades brasileiras. São Paulo: Editora da Universidade Estadual Paulista, 1992.

PINTAUDI, Silvana Maria. O shopping center no Brasil: condições de surgimento e estratégias de localização. In: PINTAUDI, Silvana Maria; FRÚGOLI JR, Heitor. (Orgs) Shopping centers: espaço, cultura e modernidade nas cidades brasileiras. São Paulo: Editora da Universidade Estadual Paulista, 1992. 
PREFEITURA DE SÃO PAULO. Plano Diretor Estratégico do Município (2014). Lei 16.050, de 31 de julho de 2014. São Paulo, 2014. Disponível em: <http://gestaourbana.prefeitura. sp. gov.br/marco-regulatorio/plano-diretor/arquivos/>. Acesso em 26 jan. 2018.

Cadernos das Subprefeituras - Material de apoio para Revisão Participativa dos Planos Regionais das Subprefeituras, Subprefeitura Pirituba-Jaraguá (2016). São Paulo, 2016. Disponível em: <http://gestaourbana.prefeitura.sp.gov.br/ marcoregulatorio/planos-regionais/arquivos/>. Acesso em 26 jan. 2018.

QUEIROGA, Eugênio Fernandes. A megalópole e a praça: o espaço entre a razão de dominação e a razão comunicativa. Tese (doutorado) Faculdade de Arquitetura e Urbanismo da Universidade de São Paulo, FAUUSP. São Paulo, 2002.

Dimensões públicas doespaço contemporâneo: resistências etransformações de territórios, paisagens e lugares urbanos brasileiros. Tese (livre docência) Faculdade de Arquitetura e Urbanismo da Universidade de São Paulo, FAUUSP. São Paulo, 2012.

Da relevância pública dos espaços livres: um estudo sobre metrópoles e capitais brasileiras. Revista do Instituto de Estudos Brasileiros. São Paulo, n.58, p.105132, jun. 2014. Disponível em: <https://www.revistas.usp.br/rieb/article/ view/82387>. Acesso em: 22 jan. 2018.

QVORTRUP, Jens. Visibilidade das crianças e da infância. Tradução de Bruna Breda. Revista Linhas Críticas, Brasília, v.20, n.41, p.23-42, 2014. Disponível em: <http:// periodicos.unb.br/index.php/linhascriticas/ article/view/9308/7743>. Acesso em: 12 set. 2017.

ROCHA, Paulo Mendes da. Maquetes de papel. São Paulo: Cosac Naify, 2007.

ROSSARI, Tânia Torres. Demarcação de identidades em espaços coletivos: o shopping Iguatemi de Porto Alegre. In: PINTAUDI, Silvana Maria; FRÚGOLI JR, Heitor. (Orgs) Shopping centers: espaço, cultura e modernidade nas cidades brasileiras. São Paulo: Editora da Universidade Estadual Paulista, 1992.

SANTOS, Carlos Nelson Ferreira dos. A cidade como um jogo de cartas. Niterói: Universidade Federal Fluminense: EDUFF; São Paulo: Projeto Editores, 1988. 
SANTOS, Milton. Metrópole corporativa fragmentada: o caso de São Paulo. São Paulo: Nobel: Secretaria de Estado da Cultura, 1990.

SARLO, Beatriz. A Cidade Vista: Mercadorias e cultura urbana. $1^{\text {a }}$ ed. Tradução de Monica Stahel. São Paulo: Editora WMF Martins Fontes, 2014.

SARMENTO, Manuel Jacinto; PINTO, Manuel. As crianças e a infância: Definindo conceitos delimitando o campo. In: PINTO, Manuel; SARMENTO, Manuel (Coords.). As crianças: Contextos e identidades. Braga: Instituto de Estudos da Criança da Universidade do Minho, 1997.

SARMENTO, Manuel Jacinto; FERNANDES, Natália; TOMÁS, Catarina. Políticas públicas e participação infantil. Educação, Sociedade \& Culturas, Porto, n.25, p.183-206, 2007. Disponível em: <https://www.fpce.up.pt/ciie/revistaesc/ESC25/ ManuelJacinto Sarmento.pdf>. Acesso em: 21 jan. 2018.

SARMENTO, Manuel Jacinto. Conhecer a infância: os desenhos das crianças como produções simbólicas. In: MARTINS FILHO, Altino José e PRADO, Patrícia Dias (orgs.). Das pesquisas com crianças à complexidade de infância. Campinas, SP. Editora Autores Associados, 2011.

SIMMEL, Georg. Filosofia da paisagem. In: SIMMEL, Georg. La tragédie de I aculture et autres essais. Tradução de Sabine Cornille e Philippe Ivernel. Paris: Editions Rivages, 1988. [Tradução para o português de Vladimir Bartalini para uso exclusivo da disciplina AUP 5882 - Paisagem e Arte: Intervenções Contemporâneas, do Curso de Pós-Graduação da Faculdade de Arquitetura e Urbanismo da Universidade de São Paulo]. São Paulo: FAUUSP, 2013.

THIOLLENT, Michel. Pesquisa-ação nas organizações. São Paulo: Atlas, 1997.

TOLEDO, Leslie; FLORES, Maria Luiza Rodrigues; CONZATTI, Marli (Orgs.). Cidade Educadora: a experiência de Porto Alegre. São Paulo: Cortez: Instituto Paulo Freire, 2004.

TOMÁS, Catarina. Participação não tem Idade: Participação das Crianças e Cidadania da Infância. Contexto \& Educação, ljuí - Rio Grande do Sul, v.22, n.78, p.45-68, jul.-dez.2007. Disponível em: <https://www.revistas.unijui.edu.br/index. php/ contextoeducacao/article/view/1065/814>. Acesso em: 21 jan. 2018. 
TONUCCI, Francesco. Quando as crianças dizem: agora chega! Tradução de Alba Olmi. Porto Alegre: Artmed, 2005.

La ciudad de los niños ¿Por qué necesitamos de los niños para salvar las ciudades? I.T., n.75, p.60-67, 2006. Disponível em: <https://presupuestosparticipativos. com/wp-content/uploads/2017/01/08-Francesco-Tonucci.pdf>. Acesso em: 13 jan. 2018.

Frato: 40 anos com olhos de criança. Tradução de Maria Carmen Silveira Barbosa. Porto Alegre: Artmed, 2008.

Ciudades a escala humana: la ciudad de los niños. Revista de educación, Madri, número extraordinário, p.147-168, 2009. Disponível em: <http://www.revistaeducacion. mec.es/re2009/re2009_07.pdf>. Acesso em: 13 jan. 2018.

La ciudad de los ninos. Barcelona: Graó, 2015.

La ciudad de los niños. Tradução de Jaume Gavaldá. Fano: Laboratorio Fano la città dei bambini. [s.d.]. Disponível em: <https://pt.scribd.com/document/109534245/ La-ciudad-de-los-ninos-Francesco-Tonucci>. Acesso em: 13 jan. 2018.

TREVISAN, Gabriela. Aprendizagens na construção de pesquisa com crianças e sobre as crianças. Currículo sem Fronteiras (revista digital), v.15, n.1, p.142-154, jan./abr. 2015. Disponível em: <http://www.curriculosemfronteiras.org/vol15iss1articles/ trevisan.pdf >. Acesso em: 21 jan. 2018.

UNICEF, Fundo das Nações Unidas para a Infância. Guia da Plataforma dos Centros Urbanos - Edição 2013-2016. Brasil, 2013. Disponível em: < https://www.unicef.org/ brazil/pt/guia_metodologia_pcu_ed1316rev2.pdf>. Acesso em 04 jan.2018.

VIANNA, Cláudia. Ações coletivas docentes e a Cidade Educadora. In: TOLEDO, Leslie; FLORES, Maria Luiza Rodrigues; CONZATTI, Marli (Orgs.). Cidade Educadora: a experiência de Porto Alegre. São Paulo/Buenos Aires: Cortez: Instituto Paulo Freire: Ciudades Educadoras América Latina, 2004.

VIEIRA, Rosa Maria. Shopping centers - espaço, cultura e modernidade nas cidades brasileiras (resenha). Revista de Administração de Empresas, São Paulo, v.34, n.3, p.146-148, mai-jun 1994. 
VILLAÇA, Flávio. Reflexões sobre as cidades brasileiras. São Paulo: Studio Nobel, 2012.

VOGEL Arno, VOGEL Vera Lúcia de Oliveira, LEITÃO, Gerônimo E. de Almeida. Como as crianças vêem a cidade. Rio de Janeiro: Pallas: Flacso: UNICEF, 1995.

WYPYCH, Patrícia Regina. Shopping center: um espaço de lazer e socialização para o adolescente. Revista Mediação, Belo Horizonte, v.13, n.13, p.138-151, jul-dez 2011.

\section{SITES CONSULTADOS:}

APÉ ESTUDOS EM MOBILIDADE. Disponível em: <http://apemobilidade.org/>. Acesso em: 04 jan. 2018.

ASSOCIAÇÃO INTERNACIONAL DE CIDADES EDUCADORAS (AICE). Disponível em: <http://www.edcities.org/>. Acesso em: 11 jan. 2018.

CARONA A PÉ. Disponível em: <http://caronaape.com.br/>. Acesso em: 04 jan. 2018.

CENTRO DE REFERÊNCIA EM EDUCAÇÃO INTEGRAL. Disponível em: <http:// educacaointegral. org.br>. Acesso em: 26 jul. 2017.

CIDADE-ATIVA. Disponível em: <https://www.cidadeativa.org.br/>. Acesso em: 04 jan. 2018.

CIDADE EM MOVIMENTO. Disponível em: <http://www.cidadeemmovimento.org/ premiomobilidademinuto>. Acesso em: 04 jan. 2018.

CIDADE ESCOLA APRENDIZ. Disponível em: <http://www.cidadeescolaaprendiz.org. br/>. Acesso em: 26 jul. 2017.

CIDADES EDUCADORAS. Disponível em: <http://cidadeseducadoras.org.br>. Acesso em: 11 jan. 2018.

DEPARTAMENTOESTADUAL DETRÂNSITO. Disponível em:<https://www.detran.sp.gov. $\mathrm{br} / \mathrm{wps} / \mathrm{wcm} / \mathrm{connect/portaldetran/detran/detran/estatisticastransito>.} \mathrm{Acesso} \mathrm{em:}$ 18 de jan. 2018. 
DESENVOLVIMENTO RODOVIÁRIO S/A (DERSA). Disponível em: <http://www.dersa. sp.gov.br/ empreendimentos/rodoanel-mario-covas>. Acesso em 26 jan. 2018.

EMEF PRESIDENTE CAMPO SALLES. Disponível em: <https://campossalles. wordpress. com/>. Acesso em: 04 jan. 2018.

EMPRESA PAULISTA DE PLANEJAMENTO METROPOLITANO S/A - EMPLASA. Disponível em: <https://www.emplasa.sp.gov.br/>. Acesso em 09 fev. 2017.

GOVERNO DO ESTADO DE SÃO PAULO. Disponível em: <http://www.saopaulo.sp.gov.

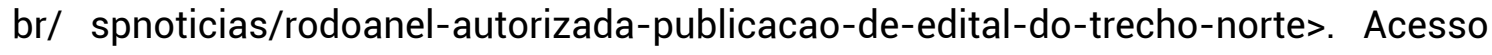
em 26 jan. 2018.

INSTITUTO BRASILEIRO DE GEOGRAFIA E ESTATÍSTICA. Disponível em: <https:// cidades.ibge. gov.br/brasil/sp/sao-paulo/panorama>. Acesso em: 18 de jan. 2018.

LA CITTÀ DEI BAMBINI. Disponível em: <www.lacittadeibambini.org>. Acesso em: 04 jan. 2018.

PORTAL APRENDIZ. Disponível em: <http://portal.aprendiz.uol.com.br>. Acesso em: 26 jul. 2017.

PREFEITURA DE SÃO PAULO - INFOCIDADES. Disponível em: <http://infocidade. prefeitura.sp. gov.br/>. Acesso em 04 nov. 2017.

REDE NACIONAL DA PRIMEIRA INFÂNCIA. Disponível em: <http://primeirainfancia.org. br/criancaeoespaco/>. Acesso em: 04 jan. 2018.

SECRETARIA MUNICIPAL DE PLANEJAMENTO - SEMPLA. Disponível em: <http://www. prodam. sp.gov.br/spn/>. Acesso em 09 fev. 2017. 
ANEXOS 
ANEXO 01

AUTORIZAÇÃO PARA PARTICIPAÇÃO E REGISTRO DAS CRIANÇAS NAS OFICINAS REALIZADAS POR ESSA PESQUISA

\section{Senhores pais ou responsáveis}

Olá! Meu nome é Paula e sou estudante de Arquitetura da Pós-graduação da Faculdade de Arquitetura e Urbanismo da Universidade de São Paulo (FAU USP). Durante os meses de setembro, outubro e novembro de 2016, estarei desenvolvendo um trabalho junto com a professora Vera e com os alunos, em que buscarei trabalhar com as crianças a relação delas com a cidade. Essas atividades serão desenvolvidas de acordo com os conteúdos programados pela professora Vera e acontecerão durante o período das aulas, porém, por serem atividades que também serão utilizadas em meus estudos, solicito a autorização para a participação dos alunos e para que possam ser registrados durante as atividades.

Obrigada, Paula Martins Vicente.

\section{AUTORIZAÇÃO}

$\mathrm{Eu}$

pelo(a) aluno(a) ,responsável

autorizo a sua participação, o registro fotográfico e a utilização, para fins acadêmicos, dos materiais obtidos durante as atividades propostas pela estudante de Arquitetura Paula Martins Vicente, da Pós-graduação da Faculdade de Arquitetura e Urbanismo da Universidade de São Paulo (FAU USP), juntamente com a professora Vera Valgas.

São Paulo, de setembro de 2016 .

Assinatura do responsável 


\section{ANEXO 02}

\section{PERGUNTAS APLICADAS AOS PAIS OU RESPONSÁVEIS PELAS CRIANÇAS}

PARTICIPANTES DESSA PESQUISA

UNIVERSIDADE DE SÃO PAULO

A

POS-GRADUAÇÃO DA FACULDADE DE ARQUITETURA E URBANISMO MESTRADO EM ARQUITETURA E URBANISMO: PAISAGEM E AMBIENTE

LINHA DE PESQUISA: PAISAGEM E SOCIEDADE

A RELAÇÃO DA CRIANÇA COM A CIDADE

(Arq. Paula Martins Vicente)

Nome do aluno (opcional):

Nome do responsável (opcional)

1. Hoje, como você considera que a cidade é para as crianças? Há alguma coisa para ser melhorada? 0 quê?

Siguronça (Yurigesa)

2. Em relação aos espaços livres públicos (parques, praças, ruas, calçadas, escadarias... como eles são utilizados pelas crianças (filhos, netos, sobrinhos, vizinhos...)? Ainda pensando nas crianças, há alguma coisa nesses espaços que poderia ser melhorada? quê? Sim exs Brimquedes é es rijias deriom ter mais peliciamentos procos, parques etc. 
UNIVERSIDADE DE SÃO PAULO

PÓS-GRADUAÇÃO DA FACULDADE DE ARQUITETURA E URBANISMO

MESTRADO EM ARQUITETURA E URBANISMO: PAISAGEM E AMBIENTE UINHA DE PESQUISA: PAISAGEM E SOCIEDADE

\section{A RELAÇÃO DA CRIANÇA COM A CIDADE}

(Arq. Paula Martins Vicente)

Nome do aluno (opcional)

Nome do responsável (opcional)

1. Hoje, como você considera que a cidade é para as crianças? Há alguma coisa para ser melhorada? O quê?

Perigosa!

Sim, a segurança, educaçás e saúde.

2. Em relação aos espaços livres públicos (parques, praças, ruas, calçadas, escadarias...)

como eles são utilizados pelas crianças (filhos, netos, sobrinhos, vizinhos...)? Ainda pensando nas crianças, há alguma coisa nesses espaços que poderia ser melhorada? 0 quê?

Sáo usados com pouco desempento, espaco e seguranca. Pois muitos parques estäo com poucos brinquedos, e quando tem, se encontram quebrados.

Sem contar a falta de seguranca que existe, devido drogas e roubos, nà temos confiansa de deixá-los brincar soginhos Teria que ter mais parques com segunanca e diversos bringuedos e também teria que ter mals bibliotecas para a cultura das criancas! 
UNIVERSIDADE DE SÃO PAULO

PÓS-GRADUAÇÃO DA FACULDADE DE ARQUITETURA E URBANISMO

MESTRADO EM ARQUITETURA E URBANISMO: PAISAGEM E AMBIENTE

LINHA DE PESQUISA: PAISAGEM E SOCIEDADE

\section{A RELAÇÃO DA CRIANÇA COM A CIDADE}

(Arq. Paula Martins Vicente)

Nome do aluno (opcional)

Nome do responsável (opcional):

1. Hoje, como você considera que a cidade é para as crianças? Há alguma coisa para ser melhorada? $\mathrm{O}$ quê?

foge en día está razoravelmente bon, Rá

algumas pracas e "parquinhos" que as

da seguranca hoge em dia no nosso paús,

sence bom que hourese mais seguranca

nos parques e pracas do nosso bano,

para que assin possanos soir mais frequen

2. Em relação aos espaços livres públicos (parques, praças, ruas, calçadas, escadarias...

(n)

quê?

bom!' como havia dito a sequranca é.

primondial „nesses locals.; porem nuas mall-sinalizades,

Calcads cheias de mat, ou ate mesmo locais que noi há calcoda poova passar, forcondo assin eniancas e todos demais que por ali possam a is pra nua, se arriscando por noó Ter opcoo, já que preasam passar por alí Todos os dias. 
PÓS-GRADUAÇ̃̃o DA FACULDADE DE ARQUITETURA E URBANISMO

MESTRADO EM ARQUITETURA E URBANISMO: PAISAGEM E AMBIENTE

UINHA DE PESQUISA: PAISAGEM E SOCIEDADE

\section{A RELAÇÃO DA CRIANÇA COM A CIDADE}

(Arq. Paula Martins Vicente)

Nome do aluno (opcional):

Nome do responsável (opcional):

1. Hoje, como você considera que a cidade é para as crianças? Há alguma coisa para ser melhorada? O quê?

acho que poduran th mais avea oh lazer para do crionces lugares mais

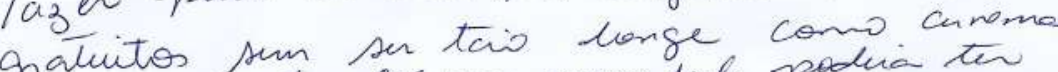
gratuitos sum lo' na zona sul podua ter

que se chatutos teatis ponques sem ser nas pudids por dandolos e uxians de do as feguon, ga

2. Em relação aos espaços livres públicos (parques, praças, ruas, calçadas, escadarias.... como eles são utilizados pelas crianças (filhos, netos, sobrinhos, vizinhos....)? Ainda pensando nas crianças, há alguma coisa nesses espaços que poderia ser melhorada? 0 quê?

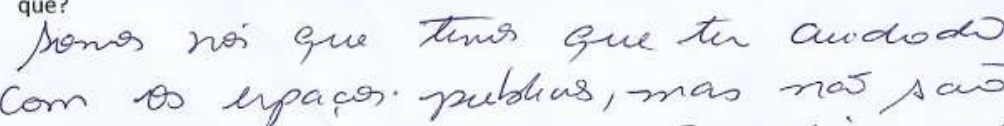
supre gursoos que ransá artin nos divianos andar mehor das nessespras parques. Oreio que ene ceí von ser mito oprovertoul p/nos, fuhos. 
PÓS-GRADUAÇĀO DA FACULDADE DE ARQUITETURA E URBANISMO

MESTRADO EM ARQUITETURA E URBANISMO: PAISAGEM E AMBIENTE UINHA DE PESQUISA: PAISAGEM E SOCIEDADE

\section{A RELAÇÃO DA CRIANÇA COM A CIDADE}

(Arq. Paula Martins Vicente)

Nome do aluno (opcional):

Nome do responsável (opcional):

1. Hoje, como você considera que a cidade é para as crianças? Há alguma coisa para ser melhorada? 0 quê?

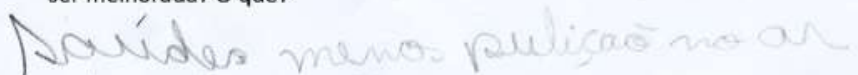

mais Edveracas.

2. Em relação aos espaços livres públicos (parques, praças, ruas, calçadas, escadarias... como eles são utilizados pelas crianças (filhos, netos, sobrinhos, vizinhos....)? Ainda pensando nas crianças, há alguma coisa nesses espaços que poderia ser melhorada? 0 quê? 
UNIVERSIDADE DE SÃO PAULO

PÓS-GRADUAÇ̃̃ DA FACULDADE DE ARQUITETURA E URBANISMO

MESTRADO EM ARQUITETURA E URBANISMO: PAISAGEM E AMBIENTE

UINHA DE PESQUISA: PAISAGEM E SOCIEDADE

\section{A RELAÇÃO DA CRIANÇA COM A CIDADE}

(Arq. Paula Martins Vicente)

Nome do aluno (opcional):

Nome do responsável (opcional)

1. Hoje, como você considera que a cidade é para as crianças? Há alguma coisa para ser melhorada? O quê?

vidunte, max tem seguranca, pais os parques. tim muitos usuarios de chrogas, pumantes, muts palavioes, mais parques, polucuas mas ruas I parques

como eles são utilizados pelas criancas (filhos, netos, sobrinhos, vizinhos...)? Aind pensando nas crianças, há alguma coisa nesses espaços que poderia ser melhorada? 0 quê?

cuidar dos que timos, nai jogar lixos mas nuas, as calcadas devem rer arumadas, unclusive $\theta$ espaco da escola, pois tim lufar que apresente risco para as orearcas i mais regurancas mas ruas. 
PÓS-GRADUAÇÃO DA FACULDADE DE ARQUITETURA E URBANISMO

MESTRADO EM ARQUITETURA E URBANISMO: PAISAGEM E AMBIENTE LINHA DE PESQUISA: PAISAGEM E SOCIEDADE

\section{A RELAÇÃO DA CRIANÇA COM A CIDADE}

(Arq. Paula Martins Vicente)

Nome do aluno (opcional)

Nome do responsável (opcional)

1. Hoje, como você considera que a cidade é para as crianças? Há alguma coisa para ser melhorada? O quê?

Perugosa Na áreas escolares deveriam ser mais smalisadas, deverian haver mais isguvarea.

2. Em relaçăo aos espaços livres públicos (parques, praças, ruas, calçadas, escadarias...) como eles säo utilizados pelas crianças (filhos, netos, sobrinhos, vizinhos....)? Ainda pensando nas crianças, há alguma coisa nesses espaços que poderia ser melhorada? 0 quê? Óreas exalares, espaces publicos, alén vde náo haver nentum tipo de siralizacáo, também nōo possui nenhum tupo vde seguranca. Sendo usim dificulta norsa preocipociáo conno pais, ao devearem nonas cicuoneos bincarem 
UNIVERSIDADE DE SÃO PAULO

PÓS-GRADUAÇ̧̄o DA FACULDADE DE ARQUITETURA E URBANISMO

MESTRADO EM ARQUITETURA E URBANISMO: PAISAGEM E AMBIENTE

UNHA DE PESQUISA: PAISAGEM E SOCIEDADE

\section{A RELAÇÃO DA CRIANÇA COM A CIDADE}

(Arq. Paula Martins Vicente)

Nome do aluno (opcional)

Nome do responsável (opcional):

1. Hoje, como você considera que a cidade é para as crianças? Há alguma coisa para ser melhorada? $\mathrm{O}$ quê?

eousidero a eidade un luzeur bon paras

as eriancos 1 press elas fodem terern ehances

de abrender Gise desenvolver na vida e tren in futuro melkor.

scho que deveria melluorar sim. A adade

presse de una escela intorgrel porpue

cus tompo ver ecoler sin os pais kicareron precculpados de

2. Em relação àos espaços livres públicos (parques, praças, ruas, calcadas, escadarias.)

como eles são utilizados pelas crianças (filhos, netos, sobrinhos, vizinhos..)? Ainda

pensando nas crianças, há alguma coisa nesses espaços que poderia ser melhorada? 0

quê?

As eriancas adoram os parques, sostan muito

de brimear se sente muils felezes.

So' \& we frocisa sim melliorar, faltan

bring uedos va proca e nos parques. 
Pós-GRADUAÇ̄̃o DA FACULDADE DE ARQUITETURA E URBANISMO MESTRADO EM ARQUITETURA E URBANISMO: PAISAGEM E AMBIENTE UNHA DE PESQUISA: PAISAGEM E SOCIEDADE

\section{A RELAÇÃO DA CRIANÇA COM A CIDADE}

(Arq. Paula Martins Vicente)

Nome do aluno (opcional):

Nome do responsável (opcional):

1. Hoje, como você considera que a cidade é para as crianças? Há alguma coisa para ser melhorada? 0 quê?

Haye a cidode virau um grande bicho pepāo pona as crionces pas elus só unvm pudidos de cuidodo e tim infor mocếs por porte da midio escda e país do quanto e pirigoso andar sozinko bincar ma suo jó nāo pode su considerodo uma devidode de dinarsas yá muito eque ser melhorodo ami condo pula Mequ von ce em relação aos espaços livres públicos (parques, praças, ruas, calçadas, escadarias...)

como eles são utilizados pelas crianças (filhos, netos, sobrinhos, vizinhos...)? Ainda pensando nas crianças, há alguma coisa nesses espaços que poderia ser melhorada? 0 quê?

Em sua grande maioria sāo uttizodos di manuiras paro poritosas pois não há uno atividade de fato nucriatina e vducativa Pookira tir atividodes monitorodas, nodas

de littura, conversos, tiatros unduindo a parti cipocāo das bironcos

Atividodus edu eativas e nä no corre-corre qui nāo divea de ser nuassario paro eles. 
PÓS-GRADUAČ̃̃ O DA FACULDADE DE ARQUITETURA E URBANISMO

MESTRADO EM ARQUITETURA E URBANISMO: PAISAGEM E AMBIENTE

UINHA DE PESQUISA: PAISAGEM E SOCIEDADE

\section{A RELAÇÃO DA CRIANÇA COM A CIDADE}

(Arq. Paula Martins Vicente)

Nome do aluno (opcional):

Nome do responsável (opcional):

1. Hoje, como você considera que a cidade é para as crianças? Há alguma coisa para ser melhorada? O quê?
segurombar
Tramsporte excolar
c methoria
nas calcadas

2. Em relação aos espaços livres públicos (parques, praças, ruas, calçadas, escadarias...) como eles são utilizados pelas crianças (filhos, netos, sobrinhos, vizinhos...)? Ainda pensando nas crianças, há alguma coisa nesses espaços que poderia ser melhorada? 0 quê?
colacar mán
brinquedo
nos Porgues
e mais praca \& pubriea
na cidade 
PÓS-GRADUAÇÃo DA FACULDADE DE ARQUITETURA E URBANISMO

MESTRADO EM ARQUITETURA E URBANISMO: PAISAGEM E AMBIENTE UNHA DE PESQUISA: PAISAGEM E SOCIEDADE

\section{A RELAÇÃO DA CRIANÇA COM A CIDADE}

(Arq. Paula Martins Vicente)

Nome do aluno (opcional):

Nome do responsável (opcional):

1. Hoje, como você considera que a cidade é para as crianças? Há alguma coisa para ser melhorada? O quê?

A cerdade í muito maue estrutriada para as creancas; podersa ter mans parque pu blecas, segurance. lazen, praga, para mether a qualedade de id da das cuanpas.

2. Em relação aos espaços livres públicos (parques, praças, ruas, calçadas, escadarias...)

como eles são utilizados pelas crianças (filhos, netos, sobrinhos, vizinhos...)? Ainda pensando nas crianças, há alguma coisa nesses espaços que poderia ser melhorada? 0 quê?

elos buincom nos colecios, eseadiuon, the.

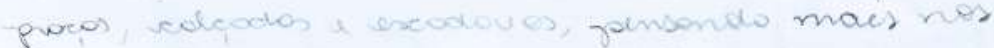

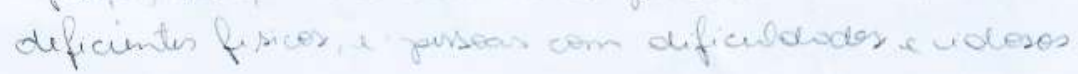

te. 
